\title{
SURVEY OF LAND AND WATER RESOURCES
}

\section{AFGHANISTAN \\ GENERAL REPORT}




\section{REPORT ON SURVEY OF IAND AND WATER RESOURCES}

\section{A F G H A N I S A N}

\section{VOLUNE I}

GENERAL REPORT

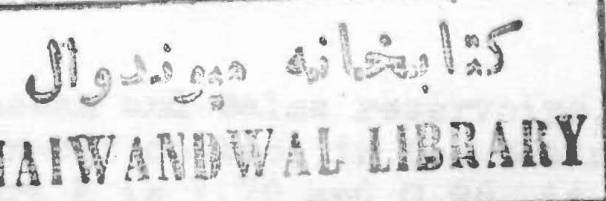

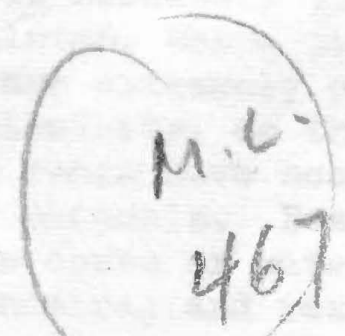

FOOD AND AGRICUITURE ORGANIZATION OF THE UNITED NATIONS 
VOIJIS I

VOIJUIS II

VOLJWE III

VOIJNE IV

VOIJUE V

VOIJIE VI
GEITRAT RIMORE

SECTIOI I - ABOLOOI

STCPIOI II - TOPOORAPHIC SURVEIS

HIDROIOAT

SOII SUEVIIS AND IAND

CINSSIFI CAYIOI

IATIB COLFROI, IRRIOAPIOI

AID POWIFR POWHITINIT

IRRIOATIOR DEVGLOPUTHAT -

HARI EUD AID KABUL BASIIS
4.D. TKLCEFV AND OTHEHS

J.B. $\triangle U D E$.

A. B. PAILISTER

A.P. JIDIKOT

V. S. SUBRAMLIIAT

I.X. IASSIROV

K.I. SATYAPAT

R.Q. JAYTOS

Q. I. FRTEIFEV $\triangle \mathrm{ID}$

I.P. AKSAKOVSKI

I.P. ARSAKOVSKI

Bach Volume contains its orm Tablo of Contents, inoluding Appondioes, and a list of the Jape and Drawings attached to it. 


\section{IIST OF MAPS AND DRAYINGS}

No.

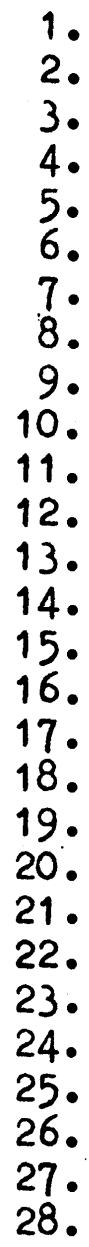

Title

Afghanistan United Nations Map. Soil Map of Afghanistan. Geo-Botanical Map of Afghanistan. Agrioulture Map of Afghanistan. Afghanistan Key Map. Afghanistan: Hydrological Key Map. Schomatic Diagram of Potential Development: Hari-Rud. Schematic Diagram of Potential Development: Farah-Rud. Schematic Diagram of Potential Development: Kabul and Shakar Dara. Proposed Irrigation Network: Hari-Rud, sheet $N^{\circ} 1$ and $N^{\circ} 2$. Irrigation Design Plot: Hari-Rud. Tentative Irrigation Network: Farah-Rud. Shakar Dara Valley: Tentative Layout of Irrigation. Kabul Valley: Tentative Layout of Irrigation. Assarassum Damsite, Concrete Buttress, Plan and Sections. Assarassum Damsite, Rockfill, Plan and Sections. Salma Damsite, Plan and Sections. Tangi Shah Damsite, Plan and Sections. Bakshabad Damsite, Plan and Sections. Alikinal Damsite, Plan and Sections. Lashkargah Damsite, Plan and Sections. Tangl Saidan Damsite, Plan and Sections. Kajao Damsite, Plan and Sections. Water Requiroments Diagram No. 1: Hari-Rud. Water Requirements Diagram No. 2: Hari-Rud. Water Requirements Diagram No. 3: Hari-Rud. Water Requirements Diagram Kabul Valley. Water Requirements Diagram, Shakar Dara Valley.

\section{Spelling of Place-names}

Note: - In preparing the text of this Volume, every effort has been made to use the same spellings of place names. Where possible, those used in the United Nations map of Afghanistan (U.N. Map No. 279 Rev. 3, March 1962) have been followed. 


\section{GLOSSART}

Afe.

Alluvium

Bod Load

Catchment Area

Colluvium

Dead Storage

Gross Heotares

Ha.

Hydromorphio.

Kares

KW

I/sec.

Loes8

$\mathbf{x}^{3} /$ Seo.

M.S.I.

Monsoon (India)

Net Heotares
Sghanl, taken for estinating purposes in this report as equal to about 0.022 U.S.\$.

Soll material deposited by water.

Coarse sodinent rolled dorm stream bed by Ilow of water.

The area from which arface flows are tributary to a river at anj particular point.

Detritus accumulated at the foot of a steep slope.

Storage oapacity in a reservoir not available for effective use, which may be beoause it is below the outlet level or beoanse it is silted up, or liable to siltation, eto.

Total area of lands within the outer limits of an irrigation soheme.

Heotare $=10,000$ aq.metres.

Soil condition developed with excessive water.

Unlined tunnel in hillside, bringing water by Iree flow from underground aoquifers for arface irrigation. Dug by local oraftemen Irom shafts at olose intervalB, they ane amall in dimensions but may be nany Kilometres in length.

$1 \mathrm{Kilowatt}=1,000$ Watts $=1.34$ British horsepower.

Litres per second. 1,000 Iitres = 1 oubio metre. Fine sediment, in general deposited by wind. Cubio metres per second.

Height (metres) above Mean Sea Level.

Summer season of heavy rains.

Area of lands within an irrigation scheme, on which orops can aotually be grom,i.e. excluding areas oocupied by canals, drains, roads, villages, eto. (In this Report tentatively assumed at 0.88 of Aross Heotares, but this proportion may vary over a considerable range). 
Piedmont

Place Names

Probability

Sediment Discharge

Sierozem

Solonohak

Speoific Index

Suspended Load

Talus

Ton

V.I.

Vad1

Water Control Coefficient

Watershed
Iand of moderate or gentle slope at the foot of a range.

There is no standard authority in Afghanistan in this matter. In the preparation of this Report, slightly different spellings of the same place names have been used in different rolumes, and it has not been possible to make all these uniform. It is believed, however, that this will not oause any confusion.

The expression a "year of X\% probability" is disoussed in Volume III - Hydrology, Chapter 5. In effeot, in this Report it is taken to mean a year auch that its discharge (whether mean, maximum or minimum) will probably be reached or exceeded in $X$ years out of 100 . For example, a year of $75 \%$ probability is a low year, below the average; a year of $20 \%$ probability is a high year above the average.

Anount of solid matter moved by the flow of a stream or river.

Gray desert soil overlying calcareous layer.

Saline soil, without structure.

Quantity per Unit of Area, e.8. Run-off in $\mathrm{L} / \mathrm{sec} /$ heotare or Cost or Value in Afg/heotare.

Finer sediment carried in suspension by flow of water in stream.

Detritus accumalated at the foot of a steep slope.

In this Report is Metric Ton of 1,000 Kilogrammes.

Vertical interval between contours.

Stream course, amall or large, normally dry but subject to flows which may be sudden, large, fast, and laden with silt and debris.

Ratio of net effective storage capacity of a reservoir to the amount of the anmal flow reaching it.

The line of higher ground forming the boundary between two adjacent catchments. 


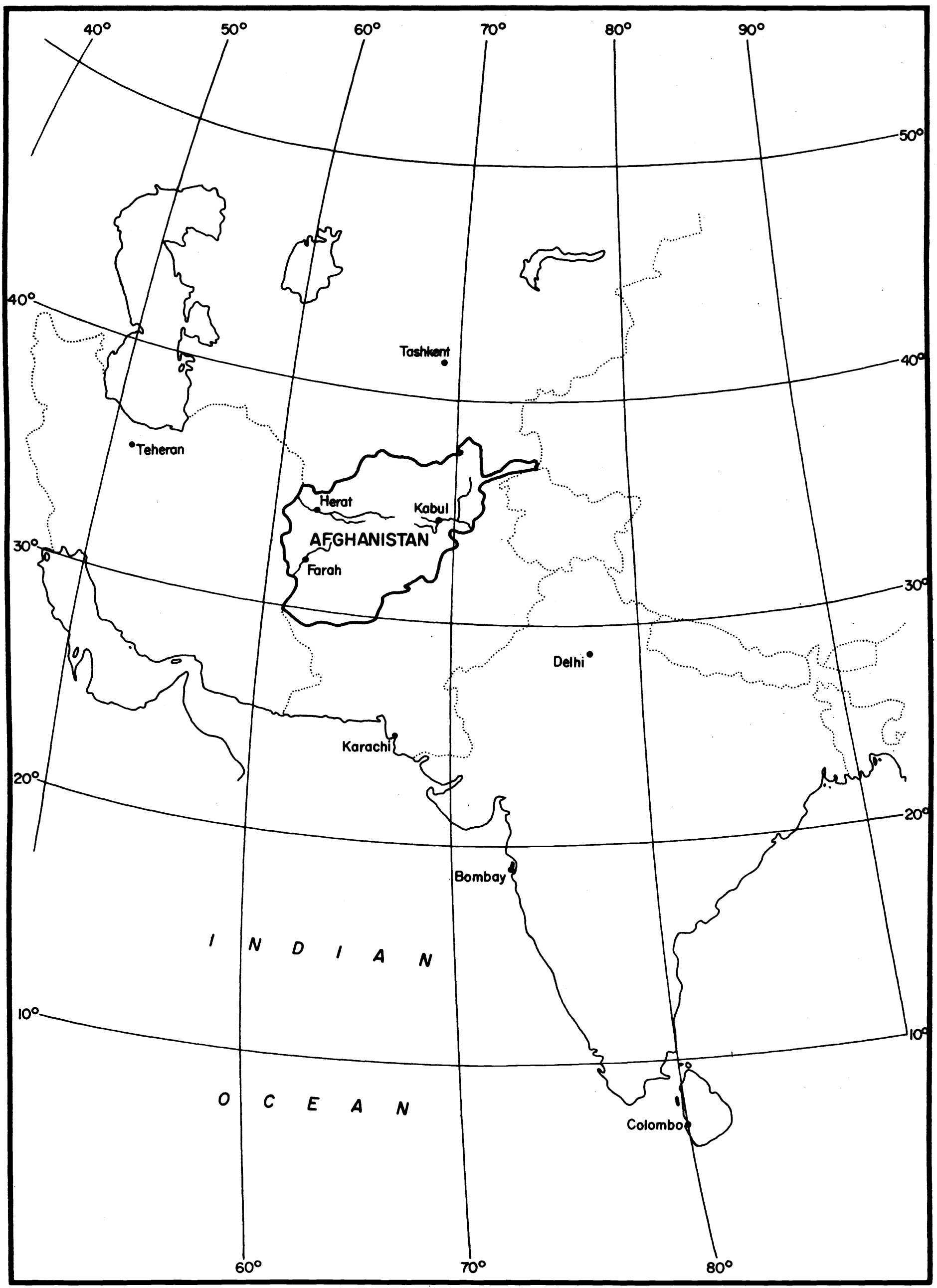


Volume I - General Report

TABTE OF CONTENTS

Chapter

Subject

Page No.

SECTION I - GENERAL

1. - Introduction. 1

2. - Summary of Main Conolusions and lecommendations.. 8

3. - General Description of Project Areas in the setting 19 of Afghanistan.

4. - Methods of Field Surveys and Office Work.

5. - Description of Besin.

6. - Soils and present Iand Use.

7. - Hydrology.

8. - Dams and Reservoirs.

9. - Potential Irrigation Development.

10. - Potential Development of Hydropower.

11. - Conclusions and Recommendations. 


\section{SECTION III - FARAH-RUD BASIN}

12. - Desoription of Basin.

13. - Soils and existing Land Use.

14. - Hydrology.

15. - Dams and Reservoirs.

16. - Potential Development of Irrigation. 92

17. - Potential Development of Hydropower. 98

18. - Conclusions and Recommendations.

\section{SECTION IV - KABUL RI VER BASIN}

19. - Description of Basin.

20. - Soils and present Land Use.

21. - Hydrology.

22. - Dams and Reservoirs.

23. - Potential Development of Irrigation.

24. - Conclusions and Recommendations.

25. - Description of Basins.

27. - Hydrology.

28. - Dams and Reservoirs.

29. - Irrlgation development.

30. - Conclusions and Recommendations. 


\section{SECTION VI - ADRASKAND RIVER BASIN}

31. - Vescription of Basin.

32. - Soil and Existing Land Use.

33. - Hydrology.

34. - Dams and Reservoirs.

35. - Potential Irrigation Development.

36. - Conclusions and Recommendations.

37. - Possibilities of Irrigation in Bakwa Valley.

\section{SECIION VII - CONCLUSIONS}

38. - Irrigation Development in the Surveyed Basins.

\section{APPENDICES}

I. - Amended Plan of Operation.

II. - Management of Iand and Water Use.

III. - Methods Used in Investigations and Planning.

IV. - List of Final Reports of Projects by FAO under EPTA, relevant to the Speoial Fund Survey Project. 
International Steff of Projeot.

Water Resources of Surveyed Rivers in their Seasonal. Distribution

Iand Suitability Classifloation.

Land Ose under Existing Conditions.

Power-Estimated Capacities and Outputs,

Hean Monthly Air Temperatures in Hari-Rud Basin.

Herat City - Mean Monthly Precipitation.

Hari-Rud - Bstimated Mean Monthly Braporation fron

Vater Surface (in mm).

Hari-Rud - Land Classification of Areas Surveyed.

Hari-Rud - Bxisting Land Use.

Hari-Rud Basin - Mean Normal Runoffs.

Hari-Rud Basin - Estimated Water Discharges of Different

Probabilities.

Hari-Bud Basin - Annual Punoff Distribution.

Hari-Rud Basin - Seasonal Runoff Distribution.

Hari-Pud Basin - Fatimated Maximum Discharges at Proposed Sites.

Hari-Rud Basin - Mean Monthly Minimum Discharges at Potential

Si tes.

Mean Annual Silt Charge of Arghandab, Kabul and Kharrar Rivers for Different Iears.

Hari-Bud Basin - Sediment Discharges.

Hari-Rud Basin - Topographical and Hydrological Description of Damsites Surveyed.

Hari-Rud Basin - Gross and Net Capacities of Potential

Reservoirs .

Hari-Pud Basin - Computed Water Bal ances and Control. Hari-lud Basin - Quantities and Costs of Potential Dams. Eerat Valley Scheme - Ranges of Agricul tural Crops. Herat Valley Scheme - Irrigation Rates.

Herat Valley Scheme - Nater Requirements for Irrigation of 130.9 thos.ha.

Herat Valley Scheme - Quantities of Main Work Itema.

Herat Valley Scheme - Costs of Irrigation Development .

Main Herat Canal - Potential Power and Energy Output of Stations at Drope.

Hari-Rud Basin - Summary of Potential Power.

Hari-Rud Valley - Land Use.

Hari-Rud Basin - Summary of Reserv Jirs .

Farah-Rud Basin - Mean Mọnthly Air Temperatures.

Parah-lud Basin - Mean Monthly Precipitation.

Mean Monthly Braporation from Water Surface.

Land Use in Farah Vaitey.

Farah-Rud Basin - Iormal Annual Runoffo.

Farah-Fud Basin - Computed Mean Annual Discharges at

Various Probabilities.

Farah-Rud Basin - Monthly Runoff Distribution.

Parah-Pud Basin - Seasonal Runoff Distribution.

Maximum Discharges of Parah-Rud of Various Probabilities.

Farah-Rud Basin - Mean Monthly Minimum Discharges at

Various Probabilities. 
프.

42

43

44

45

46

47

48

49

50

51

52

53

54

55

56

57

58

59

60

61

62

63

64

65

66

67

68

69

70

71

72

73

74

75

76

77

78

79

80

Description

Farah-Rud Basin - Sediment Discharge. Characteristics of Farah-Rud Reservoirs. Farah-Rud Basin - Balance Computations for Three Typical Years. Required Capacity of Farah-Rud Reservoirs. Farah-Rud Basin - Quantities of Main Work Items and Cost of Projected Reservoirs. Farah-Rud Valley- Land Classes and their Location. Farah-Rud - Main Lands on Right and Left Banks. Farab-Rud Reserv irs - Hydropower Resources . Kabul Basin - Mean Annual Air Temperatures. Kabul Basin - Mean Montbly Precipitation. Kabul Basin - Estimated Mean Monthly Evaporation Prom Water Surface. Meteorological Stations in Kabul Area. Kabul Basin - Land Resources of the Part Surveyed. Kabul Basin - Present Land Use. Kabul Basin - Average Annual Runoffs at Various Damsites. Kabul Basin - Estimated Mean Annual Discharges of Various Probabilities.

Kabul Basin - Monthly distributions of Annual Flows. Kabul Basin - Estimated Maximum River Discharges of Various Probabilities. Kabul Basin - Estimated Minimum River Discharges of Various Probabilities.

Kabul Basin - Sediment Discharges at Various Sites. Kabul River - Percentage Composition of Sediments. Kabul Basin - Main Features of Tangi Saidan and Kajao Reservoirs. Tangi Saidan and Kajao Dams - Quantities and Costs of Works. Tangi Saidan and Kajao Reservoirs - Speoific Costs. Shakar-Dara Valley - Areas Irrigable from Different Sources. Ghorband and Panjshir Rivers - Comparison of Runoffs and Requirements Year of $75 \%$ Probability. Kabul and Logar Rivers - Monthly Water Requirements for Irrigation.

Kabul Basin - Specific Costs, Profits and Periods for Repayment.

Chazni and Nahar Basins - Mean Montly Air Temperatures.

Ghazni Basin - Mean Monthly Procipitation.

Ghazni Basin - Mean Monthly Braporation.

Qhazni Provinco - Land Classification.

Ghazni Province - Fristing Land Use.

Chazni and Nahar Rivers - Normal Annual Runoffs.

Ghazni and Nahar Rivers - Annual Flow Fluotuations.

Ghazni and Nahar Rivers - Distribution of Runoffe within the Year.

Chazni and Nahar Rivers - Bstimated Maximum Discharges. Adraskand and Rud-i-Ghaz - Estimated Normal Annual Runoffs. Adraskand and Rud-1-Ghaz - Runoff Distribution within the Year. 
SECTION I - GENERAL

CHAPTIER 1 - INTRODUCTION

1. Inception of the Project. In 1960 the Royal Government of Afghanistan asked for the help of the United Nations Special Fund in investigating the potentialities for improvement and development, particularly under irrigation, of the lands in the valleys of certain rivers in the western and northern parts of the country. The Special Fund acoepted this request, and asked the Food and Agriculture Organization to be the Executing Agency. The Plan of Operations was signed by the three parties on 29 June 1960, and work was started in September 1960. During the course of the work the Plan of Operations was modified in certain respects; its final amended form was signed on 19 June 1963; a copy of this is attached as Appendix.1.

2. Purpose and Scope of the Project. The main purpose of the Project was to oarry out preliminary investigations of the water and land resources in the basins of selected river systems, and to furnish information as to their potentialities in the general and agricultural development of the country.

The Project stipulated collection of necessary data on the relative land and water potentials on the basis of reconnaissanoe surveys, to be used later as the foundation for further, more detailed investigations, researah and design for the preparation of specifio proposals for the development of land and water use. In its final form the Projeot embraced surveys of land and water resources in the basins of the following rivers:

1) Harl Fud and (2) Farah Bud, both situated in the western portion of the oountry.

3) Kabul River with its upper tributaries (Chorband, Panjshir, Shakar Dara, Bala Maidan and Logar) down to the gorge of Sarobi, situated in the eastern part of the country.

4) Khash fud and the Bakwa valley, in the south western part of the country.

5) Chazni and Nahar. Rivers, as well as the Katawaz area, centered on the village of Wazi Kwah, in the southern part of the country.

6) Adraskand River, lying to the south of the Hari Rud. (See Map No. 1 )

These surveys were oarried out on the following general liness

1) Classification of lands by soil types and grades of suitability, with a view to using them, mainly, for the development of irrigated agriculture;

2) Appraisal of the water potential of the rivers;

3) Topographical and preliminary goological surveys of potential storage sites and areas for accumulating flood waters, with a view to a better water control,

4) General appraisal of power-produoing possibilities;

5) General description of the existing land use, and proposals as to the future land use; 
6) Study of the existing irrigation systems in the Herat valley, with a view to preparation of a preliminary design for their reconstruction and improvement of their operation;

7) Preparation of a preliminary soheme for water control within the river basins.

The implementation of the Project as revised was saheduled to take $31 / 2$ years, from September 1960 to Februery 1964.

3. Project Personnel and Eguipment. As Frecuting Agency, FAO reoruited an international team for this Project, inoluding representatives of the following countries: Canada, France, India, Netherlands, U.K., U.S.A., U.S.S.R. The names with the dates of time spent on the Projeot, are given below.

\section{TABLE 1}

INTERNATIONAL STAFT

\begin{tabular}{|c|c|c|c|}
\hline No. & $\begin{array}{c}\text { Post and Field } \\
\text { of Work }\end{array}$ & Name & $\begin{array}{l}\text { Nationality } \\
\text { (Country of } \\
\text { Origin) }\end{array}$ \\
\hline
\end{tabular}

Period of Work on Projeot

Started

Ended

1. Project Manager-

Water Development

Engineer

R. Caspar

France

28.8 .60

6.11 .61

2. Project Manager-

Water Development

Engineer

N.D. Tkachev

USSR

25.5 .62

31.3 .64

3. Hydrologist

V.K. Goliatin

USSR

$9 \cdot 9.60$

30.9 .62

4. Hydrologist

A.P. Jidikov

USSR

20.11 .62

31.3 .64

5. Hydrometrist

A.I. Boyko

USSR

28.9 .60

14.3 .63

6. Hydrometrist

P.M. Abrosimor

USSR

21.3 .63

31.10 .63

7. Survey Engineer

A.E. Pallister

Canada

16.9 .60

31.3 .64

8. Survey Engineer

P. Leggiadro

Canada

25.3 .61

28.2 .63

9. Senior Engineer

(A/Project Manager)

U.K.

1.1 .61

31.7 .62

$(6.11 .61)$

$(25.5 .62)$

10. Irrigation Survey Engineer

I.P. Aksakovakg

USSR

11.11 .62

31.3 .64

11. Soil Surveyor

V.S. Subramanian

India

$$
5.12 .60
$$

25.1 .63

12. Soil Surveyor

Y.M. Nassyrov

USSR

14.1 .61

31.10 .63

13. Engi neering Goologiat

J.B. Auden

U.K.

30.8 .60

31.3 .64 


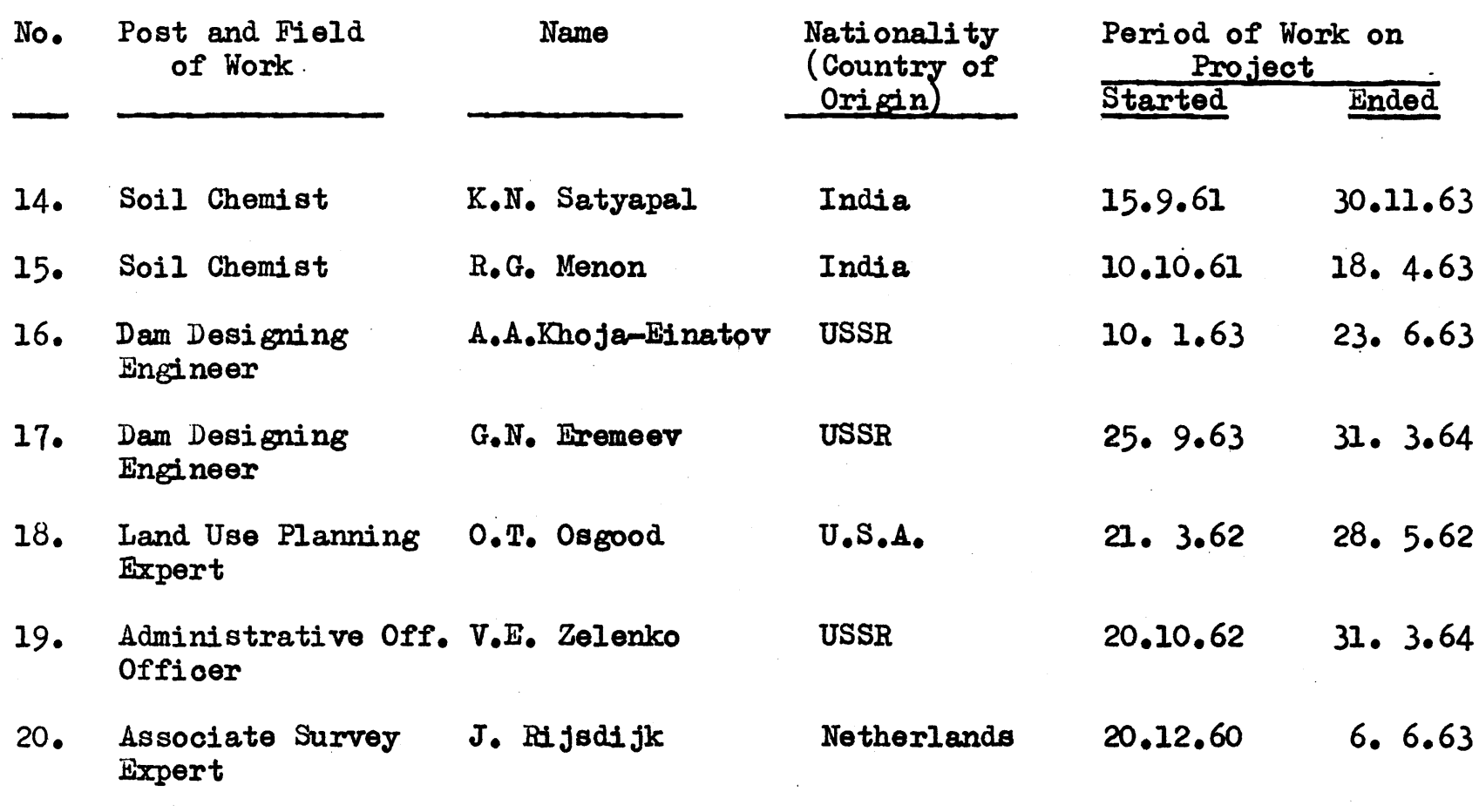

Government oounterpart staff included a hydraulic engineer, as Co-manager of the project, and some fifty other technicians, drivers, clerks etc. (see list in Appendix II). At the start of the Project the official co-operating Agency was the Ministry of Agriculture, and from June 1963, till the ond of the Project, the Afghan Land and Water Survey Authority. The Government also provided office and laboratory facilities, tools and camp equipment, stationery and office equipment eto., and met certain local operating costs.

The main field transport included ten Bussian jeep-type vehioles, five Willys Jeeps, and three Russian and one Dodge trucks. For use mainly in Kabul the team had three station wagons and one saloon car.

Although the majority of the vehioles were used under very hard conditions of wear and tear for 3-3t years, (on comparatively unmotorable roads, and often a complete lack of them), the cars were maintained in good woxking order and there were but few cases of delays in field operations due to shortages or lengthy repairs of the transport fleet.

However, as experience has shown, it would be wise in the future to ensure the services of qualified mechanios to supervise the maintenance of the vehioles as well as to have constantly in stock the minimum of spare parts for every make of the vehicles available.

All necessary tools and equipment for the various technioal operations were readily available throughout the duration of the Projeot; this was facilitated by satisfactory liaison between the Project staff and the FAO Headquarters Division concerned.

The Project team, including both the international experts and their counterparts, were acoomodated in doublemstorey offices speoially rented for the purpose in Kabul. Only the soil ahemists were outside these premises, in the laboratories of the Ministry of Agriculture. 
4. Brief History of the Projeot. The original Plan of Operations, si gned on 29 June 1960, provided for: -

(i) Studies of Land and Water Resources;

(ii) Establishment of an experimental agrioultural station.

For various reasons the Projeot for an agrioultural station was canoelled after some initial expenditure had been incurred on it. However, the need for such a station remains great if irrigated agriculture is to be properly developed.

The studies of land and water resouroes were originally specified to be done in the basins of the Kokcha and Kundus Rivers in the northerm part of the country, and of the Hari Fud and Farah Pud in the west. Work began in the basins of the Hari Rud and Farah Bud according to plan. When these were finished, early in 1962, the intention was yo start surveys in the Kokche and Kunduz Rivers. However, in Marah 1962 the Cooperating Agenoy (then the Ministry of Agriculture) requested that the proposed work in the Kokcha and Kundue valleys, where the Government was carrying on independent activities (with the help of FAO/LPTA experts and bilateral aid), should be excluded from the Plan of Operations and replaced by surveys in the upper part of the Kabul basin (down to the gorge of Sarobi); in the Chazni and Nahar basins, and the Katawaz area, in Chamni Provinoe, and in the Adraskand basin in the west.

The Revised Plan of Operations was agreed upon in prinoiple in June 1962, between the FAO Speoial Fund and the Afghan Ministry of Agriculture, as a basis for contimiation of the Project Team surveys in the areas indicated above.

It was formally signed on 19 June 1963 in Kabul. Originally, the period of the Project had been fixed for 3 years (from September 1960 till August 1963), but because of the above changes the Special Fund agreed to the FAO suggestion to extend the period of action to $31 / 2$ years.

In May 1963 the Covernment established the Land and Water Survey Authority, directly under the Cabinet, and desi gnated this body as the Government's coordinating agenoy for the surveys oarried out by the Project, releasing from these duties the Ministry of Agriculture.

Contact with the Project on the part of FAO was maintained by field visits of officers from headquarters, the operational planning and supervision being done by the Project Manager in collaboration with his Afghan Co-Manager.

In planning the programme of work, it was appreciated that the first necessity was the collection of the principal geographical data on the areas to be surveyed, by means of topographical surveys, hydrological observations, and soil and geological surveys. To make the best use of the time available, it was also necessary to concentrate on those areas which offered the best prospeots for development and could lead to the most positive results. Priorities in surveying the various basins were allotted on this basis.

Much difficulty was caused by the shortage of suitable contour maps for areas to be surveyed, quite indispensable for preliminary studies before field trips start, particularly in the sphere of preparing sketch plans for land irrigation and of carrying out topo-surveys of reservoir damsite areas. Availability of such maps could have considerably reduced the time spent by the experts, and would have contributed to a better solution of the problems arising from the very start of the Project. 
Such maps are also needed, on a scale of 1:100,000, in preparing the technical sketches of blocks for irrigation purposes, for locating the intake and determining the conditions for conveying irrigation water and thus for determining the two main indices - the technical feasibility and the economical justification of irrigation development. (See Note below).

Such sketches could easily be prepared for the valleys of the Farah Pud and Hari Rud, for which areas 1:50,000 topo-maps were available. The absence of any topocontour maps for the Kabul basin, where considerable areas of umased irrigable lands were discovered, restricted the results of the Project to providing partly complete descriptions of the soils, and to determining the availability of surface waters in the areas surveyed; that is, the land and water resources were established. The sketch design for irrigation development in this basin, however, could only be siven in a very preliminary form. (See Chapter 23).

One ereat advantage was the availability for all the areas under survey of aerial photographs, mainly at a soale of 1:60,000 - 1:70,000, and for a great part of the area, 1:25,000. These were particularly useful to the topography group of the Project, enabling them to study areas being visited on field trips, in advance.

(NOTi: The Geologioal Survey of Afghanistan already has at its disposal completed topographical contour maps at $1: 100,000$ scale, of the northern part of the country, but only advance copies of this series are available for the central, southern and western regions; as noted above, no such maps exist for the area of the Kabul basin with which the project was conoerned.

The aerial photography of the northern parts of the country was carried out by the State Administration of Geodesy and Cartography of the USSR, the central and southern regions being covered by the Fairchild Co., of U.S.A.).

5. Organization of Field Work. Wach group of experts had its own programme of work, and, as a rule, was independent in its operations. Whenever needed, the Project Nanager coordinated the relationship anong the various surveys.

However, a considerable portion of the field work of the topographical and geological groups was carried out jointly, which was advantagoous in every respect, and particularly helped in the selection of areas for reservoir damsite surveys.

In organizing field surveys, climatic conditions were always taken into consideration. As a rule, office processing work was planned for the hottest months and was to be conducted in Kabul. However, this could not always be done for lack of time and the necessity of securing data for particular parts of the work.

In the hydrometrial work, it was necessary, first to seloct gauging sites, provide them with equipment, to recruit and train observers, and then to ensure contimous observations and their regular recording.

Sites for gauging stations were chosen to be near the proposed storage damsites and to be convenient for hydrometric measurements and observations. This meant that some gauging stations were set up in localities to which access by vehicle was not possible throughout the year.

Altogether, the Team established 11 gauging stations, data from which were used for the Project. Measurements and observations at these stations are being contimed by the Land and Water Survey Authority. 
A characteristic of the field work was the sense of co-operation and mutual support between tean members, notwi thstanding differences in nationality, age, and status, and the very considerable hardships encountered in the fleld. Members of the topographical and geological teams especially often had to cover considerable distances - up to $50 \mathrm{Km}$. - on foot in very inacessible and rugged areas.

It was often a problem to find labourers to work in suah conditions. The only means of transportation to bring tools and equipment for work in such localities, as well as the camping equipment, was a caravan of camels, and it was often a problem to find any of these.

Surveys in such areas took a considerable time, and were in some cases a downricht waste. This time could have been considerably reduced and this work would have involved less effort, if the Team had had a helioopter at their disposal.

6. Training. A very satisfactory feature of the project was the co-operation with, and training of, the Afghan counterpart staff. Counterparts were assigned to each expert for speoialized training in field and office work. This aimed at the contimation of the surveys and at the development of a survey programme for the whole country, beyond the soope of this Projeot, by national personnel trained for the purpose. In particular, Afghan specialists are now independently conducting all types of hydrometric measurements and other work at gauging stations established and equipped with the help of the Project on the Hari Bud, Kawgan, Adraskand, Fud-i-Chaz, Farah lud, Malmand and Logar rivers. A group of soil soientists was trained, which is now capable of making independent field soil survoys, preparing soil maps and classifying lands. Some Afghen speoialists were trained also for independent work in topography and levelling. Two Afghen specialists received good experienoe of visual geological reconnaissance in the field.

Three Afghan specialists reoeived training under Fellowships, two in hydrology for 2 years each, in U.S.A., and one in soil survey by. interpretation of air photographs, for 1 year in Holland.

7. Cost of the Project. In acoordance with the programme of work, the total cost of the Project was estimated at \$1068.? thousand. Out of the totel:

1) Special Fund allocation - $\$ 716.9$ thousand, or $67 \%$

2) Government Counterpart Contribution - $\$ 351.3$ thousand, or $33 \%$.

The budgetary expenditure for the Special Fund Allooation and the Government's payment towards local operating costs (\$82.6 thousand), deposited on the Special Fund's account in Kabul, is divided into the following categories:-

1) íxperts' services (salaries, installation allowance, daily subsistence, etc. - $\$ 560.75$ thousand, or $70 \%$;

2) تquipment and supplies - \$141.2 thousand, or $1 \% \%$

3) Followships - $\$ 27.0$ thousand, or $3 \%$;

4) Miscellaneous expenses, including itrecuting Agency Costs - \$70.6 thousand, or $9 \%$.

More detailed information concerning the personnel, equipment and supplies provided for by the Special Fund and the Afghan Government is given in the revised Plan of Operations, attached as Appendix 1. 
Since the inception of the Projeot, \$40.5 thousand have been spent purahasing vehicles, and another $\$ 16$ thousand have been spent in keeping them in good working shape, that is for repairs, replacements and maintenance.

8. Aaknowledgements. All the members of the Project Team who were engaged in the land and water resources survey owe their gratitude to all agencies and individual offioials belonging to the Government organization or otherwise, for their help and cooperation. Their assistance in carrying out surveys and the collection of initial data, and their professional advice, based on their better understanding of the local conditions, undoubtedly had a favourable bearing on the development and finalization of the Project activities relating to the growth of the country's economy.

Thanks are due to Mr. G. Adalat, the Minister of Agriculture at the start of the Project, as well as to the present Minister, Dr. M. Keshawarz, and especially high appreciation to Mr. M.A.A. Reza, President of the Land and Water Resourcer Survey Authority, and to all his staff, for their cooperation and never-failing assistance in the Projeot's activities.

Below follows a list of agencies and individual persons who were always ready to share their experience and knowledge, and were thus very helpful in the execution of the Project:

Cartography Department of the Geological Survey of Afghanistan

(Messrs. I. Yakoubi and E. Dahle);

Department of Natural Resources, Ministry of Agriculture (Dr. A. Ahad Afzal);

Department of Soils, Faculty of Agriculture, Kabul University

(Messrs. P. Baxter and Zarif Salem, and Dr. G.A. Nilsen),

German Hydrological Group, Ministry of Mines and Industries, especially Messr8. Birkenberger and Bitomsky. Especial thanks are due for the data of river levels and discharges recorded by thems

Mr. S. Heppling, UNTAB Resident-Representative in Afghanistan;

Mr. S.K. Dey, FAO Representative in Afghanistan;

Nr. D. Hunger, Mineralogist, UNTAB Mission in Kabul.

It is also necessary to send a message of thanks to all the Afghan engineers and technicians that were assigned to every group of experts, for their great help in carrying out all the field operations since the Project's inception till its end. The responsibility for the organization of the Projeot's activities, its permanent supervision and consultations on the FAO part rested personally with Mr. A. de Vajda, Chief of Special Fund Operations, Land and Water Development Division, FAO, Rome. 
CHAPTER 2 - SUMRARY OF MATN CONCLUSIONS AND RHCOMMEIDATIONS

1. Appraisal of Land and Water Resources and Potential Irrigation Development

Good water storage potentials were disoovered on the rivers Hari fud, Kawgan, Farah Fud, and the Kabul tributaries, as well as favourable conditions for a considerable expansion of cultivated areas through the use of additional water and a better utilization of the available resources.

2. The Water Resources are summarised in Table 2. Under existing conditions, there is no water control on any of the rivers ourveyed. On all the rivers, except those of the Kabul basin, all the Iun-off during the summer and autumn-winter periods is consumed for irrigation. However, flood run-off is only partly used; its more complete use depends on regulation by the construction of dams and reservoirs.

TABLE 2

WATPR RESOURCES OF SURVEYED RIVERS IN THETR SEASONAL DISTRTBUTION

No. Name of River and Damsite Mean Normal

$$
\begin{array}{ll}
\text { disahargo } & \text { runoff } \\
\left(\mathrm{m}^{3}{ }_{\text {sec }}\right) & (\mathrm{Km} 3)
\end{array}
$$

1. Hari Fud at Marwa of whi Kawgan at Tangi Shah

2. Adraekand at confluenoe with Bud-i-Chaz

3. Farah Fud at Bakshabad

4. Kabul at Tangi Saidan

5. Iogar at Kajao

6. Panshir at Culbahar

7. Chorband at Pul-i-Ashat

8. Channt at the mouth

$\begin{array}{rr}65.0 & 2.00 \\ 15.0 & 0.47 \\ & \\ 8.6 & 0.27 \\ 44.0 & 1.40 \\ 6.0 & 0.19 \\ 10.5 & 0.33 \\ 62.5 & 1.97 \\ 27.0 & 0.85 \\ 11.0 & 0.35\end{array}$

65.0

2.00

0.35
Seasonal Distribution of Runoff \% Spring Summer hin.t Aut. March-June July-Sep. Oot.-Feb. (III-VI) (VII-IX) (X-II)

$68 \quad 22 \quad 20$

$\begin{array}{lll}58 & 13 & 29\end{array}$

$\begin{array}{rrr}71 & 4 & 25 \\ 70 & 8 & 22 \\ 52 & 6 & 42 \\ 52 & 6 & 42 \\ 53 & 38 & 9 \\ 58 & 21 & 21 \\ 83 & 1 & 16\end{array}$

Analysis of the seasonal distribution of the anmial run-off shows that during the summer and autumn-winter lor water periods (July to Fobruary) the run-off of the surveyed rivers ranges from $17 \%$ (Channi Basin) to 48\% (Kabul Basin) of the total mean normal run-off, and in the spring season, i.e. from March to June, when the flood oocurs, from $52 \%$ to $83 \%$.

3. Soil and Land Capebility Survers - Reconnaissance soil maps were made of the variou basins on a total area of over 1.7 million hectares at the soale of $1 / 50,000$, reduoed for printing to $1 / 100,000$. The mapping unit was the soil association.

Interpretative land capebility maps were also made at the same soale and were based on the suitability of soils for irrigation. Six classes were distinguished as followss

Class I : Very suitable for irrigation.

Class II : Moderately ouitable for irrigation.

Class III \& Marginally suitable for irmgation.

Class IV \& Non-arable land; not suiteble for Irmigntion, excopt under special conditions for irrigated pasture. 
Class V \& Non-arable land; undetermined suitability for irrigation. Class VI: Non-irrigable land.

(See Chapter 4, paragraph 3)

The areas covered by each alass are given in Table 3.

\section{TABLE 3}

Name of Valley and Area

\section{Hari Rud Valley}

Farah Fud Valloy

Adraskand Valley

Chazni Areas

Chazni Valley

Jilga Valley

(Chazni Tributary)

Nahar Valley

Wazikhwa Area (Katzwaz)

Dil Area (at Ab-i-Istrua

Lake)

Kabul Area

Logar Valley

Chorband, Shakar-Dara

Panjohir Valleys

TOTAL AREA:
Total Area curreyed in heotares

410,770

50,900

155,000

250,000

139,990

123,400

54,900

310,000

104,300

36,000

98,000

$1,733,260$

\begin{tabular}{c} 
CIass \\
II \\
\hline
\end{tabular}

75,730

25,000

24,700

56,100

20,050

5,600

$-$

74,740

6,240

19,400

27,300

$334,860 \quad 384,400 \quad 212,380$

11,600

14,000

54,460

16,600

48,400

26,900

-
Land Classification *

\begin{tabular}{|c|c|c|c|}
\hline $\begin{array}{l}\text { Class } \\
\text { III }\end{array}$ & $\begin{array}{c}\text { Class } \\
\text { IV }\end{array}$ & $\begin{array}{c}\text { Class } \\
\mathbf{V}\end{array}$ & $\begin{array}{c}\text { Class } \\
\text { VI }\end{array}$ \\
\hline $\begin{array}{r}63,700 \\
2,600 \\
5,000\end{array}$ & $\begin{array}{r}84,930 \\
5,800 \\
5,300\end{array}$ & $\begin{array}{r}60,760 \\
14,900 \\
100,000\end{array}$ & $\begin{array}{r}125,650 \\
2,600 \\
20,000\end{array}$ \\
\hline
\end{tabular}

$49,700 \quad 25,200 \quad 78,600$

40,400

$24,340 \quad 15,720 \quad 32,280$

$43,000 \quad 19,300 \quad 10,500$

6,000

47,600

45,000

$65,000 \quad 15,230$

35,530

11,650

23,300

119,500

5,050

$-$

22,300

*) No Class I lands were identified in the Projeot Surveys. 
In order to allow a quiak evaluation of the possibilities of future development, the existing land use is given in Table 4.

TABLE 4

IAND USE UNDER EXISTIMT CONDITIONS

\begin{tabular}{|c|c|c|c|c|c|c|c|}
\hline No. & Name of Surveyed Area & $\begin{array}{l}\text { Total } \\
\text { area of } \\
\text { lands } \\
\text { survered }\end{array}$ & $\begin{array}{l}\text { Lands。 } \\
\text { ourrently } \\
\text { irrigated }\end{array}$ & $\begin{array}{l}\text { Irrigable } \\
\text { landis not } \\
\text { irrigated } \\
\text { at present } \\
\text { due to lack } \\
\text { of water }\end{array}$ & $\begin{array}{l}\text { Proviaior } \\
\text { ally irr } \\
\text { ablo land } \\
\text { requirin } \\
\text { reolamat } \\
\text { Currently } \\
\text { used as } \\
\text { tures and } \\
\text { partiall } \\
\text { for dry } \\
\text { farming }\end{array}$ & $\begin{array}{l}n- \\
18- \\
d 8 \\
8 \\
i o n . \\
y \\
\text { pas- } \\
d \\
y \\
\end{array}$ & $\begin{array}{l}\text { Class V } \\
\text { and VI } \\
\text { lands } \\
\text { used only } \\
\text { as pasture }\end{array}$ \\
\hline & $I$ & 2 & r & 4 & 5 & 6 & 7 \\
\hline $\begin{array}{l}1 . \\
2 . \\
3 . \\
4 . \\
5 \\
6 .\end{array}$ & $\begin{array}{l}\text { Hari Bud Valley } \\
\text { Adraskand Valley } \\
\text { Farah Hud Valley } \\
\text { Chazni Valley } \\
\text { Jilga Valley } \\
\text { Nahar Valley } \\
\text { Wazlkhwa (Katawas) }\end{array}$ & $\begin{array}{r}410,770 \\
155,000 \\
50,900 \\
250,000 \\
139,990 \\
123,400\end{array}$ & $\begin{array}{r}54,700 \\
11,000 \\
15,100 \\
30,000 \\
13,940 \\
9,010\end{array}$ & $\begin{array}{l}84,730 \\
18,700 \\
12,800 \\
75,800 \\
30,450 \\
39,590\end{array}$ & $\begin{array}{r}84,930 \\
5,300 \\
5,800 \\
25,200 \\
15,720 \\
19,300\end{array}$ & $\begin{array}{l}- \\
\overline{14}, 900 \\
\overline{-} \\
-\end{array}$ & $\begin{array}{r}186,410 \\
120,000 \\
2,600 \\
119,000 \\
79,880 \\
55,500\end{array}$ \\
\hline 8. & $\begin{array}{l}\text { Area } \\
\text { Dil Area (at } A b-i-\end{array}$ & 54,900 & 2,870 & 8,730 & 14,000 & - & 29,300 \\
\hline $\begin{array}{l}9 . \\
10 .\end{array}$ & $\begin{array}{l}\text { Istada) } \\
\text { Kabul Area } \\
\text { Valleys of Chorband, } \\
\text { Panjohir and }\end{array}$ & $\begin{array}{l}310,000 \\
104,300\end{array}$ & $\begin{array}{l}10,000 \\
27,500\end{array}$ & $\begin{array}{r}129,740 \\
16,400\end{array}$ & $\begin{array}{l}15,230 \\
26,900\end{array}$ & $\overline{10,65}$ & $\begin{array}{r}155,030 \\
6,050\end{array}$ \\
\hline 11. & $\begin{array}{l}\text { Shakar-Dara } \\
\text { Logar Valley }\end{array}$ & $\begin{array}{l}98,000 \\
36,000\end{array}$ & $\begin{array}{l}38,400 \\
16,000\end{array}$ & $\begin{array}{l}36,300 \\
20,000\end{array}$ & - & - & 23,300 \\
\hline & TOTAL & $1,733,260$ & 245,320 & 473,240 & 212,380 & 25,55 & 777,070 \\
\hline
\end{tabular}

In view of the above, the following conclusions and recommendations may be drawn for the various areas surveyed:

4. Hari Rud Besin: Considering the extent of the free land and water resources available in this basin, it should be possible to develop irrigation, particularly in the Herat Valley, in the near future. (See Chapter s 8-10). Glass II and III lands in the basin oover a total of 139,400 ha.; the general character of these lands is such that for the development of irrigation they would require a minimum of reclamation work, besides the construction of irrigation systems and reservoirs where necessary.

The draft scheme of irrigation development in the Herat Valley allows for the regular irrigation of $131,000 \mathrm{ha.}$, provided the available water resources are fully used, an increase of more than 76,000 ha. over the area at present irrigated. The design for irrigation development provides for reconstruction of the intake and canalisation systems, and for transition to regular irrigation, with abolition of the orop-fallow system. Irrigation is at present by gravity, as will be the extension. The scheme covers an area of 148,800 ha. gross, (or 131,000 ha. net) mainly Class II and III lands, with a small part in Classes IV and V. The capital investment for 
reconstruotion and development of the irrigation system itself has been approximately determined as $\$ 75.5$ millions, that is $\$ 576 \%$ ha. of area irrigated.

For full Iun-off regulation, on which the oomplete development depends, four reservoirs should be constructed; two at Assarassum and Salma, will be on the Hari Fud proper, two at Tangl Azao and Tangl Shah, on the Kawgan. The reservoir capacity required for irrigation of an area of $131,000 \mathrm{ha}$. will be 1250 million $\mathrm{m}^{3}$ and the total effective capacity of the euggested reservoirs will be almost equal to this.

The total oapital investment for the work of mun-off regulation, has been estimated at approx. $\$ 32.7$ million ( $\$ 250$ per ha. of area imigated). Thus, the total expenditure for the irrigation system and for water control measures in the Hari Rud basin will be of the order of $\$ 108.2$ millions. This includes expenditure for development of the hydropower resources in the valley. The design provides for the construction of 5 hydropowar stations at a total rated capacity of $85,500 \mathrm{Kw}$., one each at the Assarassum and Salma dam sites and three at the drops of the Herat right bank main canal. (See Chapter 8 - 10)

It should be noted that these estimates of cost, and others given below, are highly tentative. They are subjeot to considerable changes, depending on the results of further extensive surveys and investigations, and on the inevitable future variations in the costs of materials, services and equipment. However, there is no doubt that the Herat valley has all the pre-requisites for imrigation development on a large soale.

5. Basin of the Farah Fud. The proposed development of irrigation in the Farah valley, described in Chapters 15-17, covers a total area of 48, 300 ha. of irrigable lands, and will bring up the area irrigated to 33,300 ha. (See Table 35, Chapter 13). However, in implementing this saheme, together with run-off regulation, water supply will be available sufficient for an area of 59,200 ha., including visually-surveyed lands in the Daulatabad area and at Juwain. Moreover, while the area at present irrigated in this basin amounts to only 15,000 ha., the mean normal run-off might, with over-year storage, suffice ultimately to irrigate some 90,000 ha.

The present development saheme, to cover 59,200 ha., provides for gravity irrigation, with easy water intake conditions from the river; the valley has good terrain for the construction of the necessary water distribution and irrigation system. At the same time, the existence of considerable areas of land wich are saline in various degrees, will require thorough hydrologioal investigations to provide a collector-drain system. The scheme also considers the construction of a reservoir at Bakshabad, Alikinai or Lashkagar, which would enable the irrigated area to be inareased to $60,000 \mathrm{ha}$, allowing for the oultivation of up to $50 \%$ of cash crops. Of the three potential reservoirs, that at Bakshabad is recommended for run-off regulation, being the cheapest and nearest to the potential irrigated land. The cost of this would amount to $\$ 15.55$ millions. Allowing development of irrigation works at the rate of $\$ 680 / \mathrm{ha}$, to a total of $\$ 40,250$ million, the overall cost for irrigation development and run-8ff regulation over $59,200 \mathrm{ha}$. would be $\$ 55.8$ million. This figure includes expenditure for the development of hydropower, with the construction of a station with rated capacity of $24,000 \mathrm{KW}$ at Bakshabad.

However, in spite of the above possibilities, irrigation development in the Farah Valley, judging by its importance, should be given third priority, after that in the Herat and Kabul valleys. (See below, para 14). 
6. Kabul Basin. The prospeots for irrigation development in the Kabul area are favourable. Of the $238,300 \mathrm{ha}$. of land surveyed, $172,400 \mathrm{ha}$. are in classes II and III. These lands have good texture, adequate drainage by lift or outflow, and are almost entirely free from salinity. At present, just over 50\% of these lands are anmually irrigated.

Preliminary investigations lead to the conclusion that dam construction is possible on the Logar, Bala Maidan and Chorband rivers (Kabul tributaries). Observation shows that the natural flows of the Chorband and Panjohir have considerable potential resources at present umised, even without storage, whereas the unregulated flows of the Bala Maidan (upper Kabul) and Logar rivers are already completely used for irrigation during the low-water season.

Accordingly, the following soheme is proposed for irrigation development in the Kabul Basins

(i) In the Panjshir and Chorband (Shakardara) valleys, the intensively cultivated area of 21,600 ha. should be increased to 50,400 ha, by irrigation without water control by storage.

(ii) From the Kabul (Bala Maidan) and Logar rivers, using water control by reservoirs, the irrigated area should be increased from 27,500 to 43,500 ha. The development of hydropower at these reservoir dams will not be economio.

Because contour maps of these areas are still lacking, this saheme must be considered as quite tentative, being framed only on visual observations and some preliminary data on ground elevations. Costs can only be forecast very approximately. Definite planning will require contour maps, detailed surveys and field investigations, and comprehensive designs. However, even the preliminary discussion of this saheme, in Volume VI, Chapters 22 and 23, leaves little doubt as to the profitability of irrigation development base. Moreover, these lands are near the oapital city, in a well-populated area, where the country's joung but developing textile and sugar industries will require raw materials.

7. Khash lud basin. Based on the aerial photographs only, a preliminary indioation was obtained from the geologist as to the potential use of the Khash Rud waters for the irrigation of part of the lands in the Bakwa valley. On present information, the prospects do not appear promising, (See Volume II).

8. Chazni and Nahar basins. In the Chazni Province, out of the total area surveyed in the basins of the Chazni, Nahar, and (in part) Lora rivers, as well as in the Wazikhwa (Katawaz) area, in all 878,300 hectares, lands suitable for irrigation total 439,700 hectares, of which 344,100 hectares are Class II and III lands. Of these lands, about 65,800 hectares are at present irrigated.

On the whole, the Chazni Provinoe has large potential land resources fit for irrigation development, but very limited surface waters: the anmal run-off of the Chazni and Nahar rivers does not exceed 436 million m 3 . On the other hand, preliminary investigations indicate that irrigation might be developed by the use of ground water. However, this should be preceded by special surveys, and perticularly by a hydrogeological study. This work is to be covered by a new Special Fund Project. (See 15, below). 
9. Adraskand basin. This basin has 35,000 ha. of irrigable land, but very limited water resources. Only $11,000 \mathrm{ha}$. are irrigated at present, and only a further 5,000 ha. could be irrigated. Even to bring about this extra use of good land, full regulation of run-off of the Adraskand river would be necessarys this in turn depends upon the construotion of a reservoir. Hydrological aalculations show that the anmal mun-off of the Adraskand, below its confluence with the Bud-i-Ghaz, does not exceed 270 million $\mathrm{m}^{3}$.

Geological and topographical reconnaissances in the basin have so far indicated no suitable sites for dams and reservoirs, but further investigations in the neighbourhood of Jija Serai appear to be desirable.

Following the above, the investigation in the Adraskand basin was. Iimited to a study of the land and water resources, without preparation of any proposals for their use.

10. Appraisal of Potential Development of Power Production. Brief data are given below on the hydropower resources of the Hari. Rad and Farah Rud, that could be used through construotion of hydropower stations at reservoir dems and on main irrigation canals. No power stations are at the dams on the Kabul tributaries proposed in this report.

A detailed description of these resources is given in the respective chapters in this Volume dealing with each of the basins surveyed.

Table 5 below gives data on the estimated capacity and output of the hydropower plants that could be constructed in the basins of the Hari Rud and Farab Rud.

\section{TABIT 5}

POWER - ESTIMATED CAPACITIES AND OUTPUTS

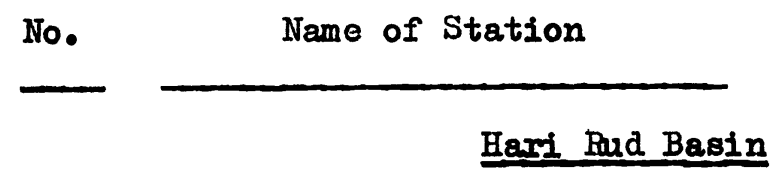

1. At Assarassum dam
2. At Sa]ma dam
3. At $\mathrm{Km} \cdot 22$ of main canal
4. At $\mathrm{Km} \cdot 38.7$ of main canal
5. At $\mathrm{Km} \cdot 64$ of main canal

TOTALs

\begin{tabular}{ll} 
Estimated & Output \\
Capacity (Kwt) & (Miln.Kw-hrs) \\
\hline
\end{tabular}

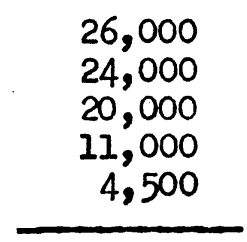

85,500

$\begin{array}{r}98.87 \\ 109.38 \\ 141.10 \\ 77.65 \\ 31.79 \\ \hline 458.79\end{array}$

Farah Bud Basin
6. At Bakshabad dam, or at Alikinai dam, or at Lashkagar dam

$\begin{array}{ll}24,000 & 131.6 \\ 26,000 & 149.0 \\ 34,000 & 188.2\end{array}$

Provision for power developments found possible should be included in the designs of works for water control and irrigation, even if installation is not considered to be fustifiable when the works are first built. 
11. Recommendations for Further Survers and Studies. The purpose of the surveys made in the seleoted basins was limited to the determination of the land and water potentials, and to general appraisals of the possibilities of their further development. Defore irrigation development can be started on a large scale, additional studies will be necessary, to produce plans for woh of the basins, and first of all in the basins of Hari Rud, Farah Fud and Kabul.

The additional studies should include the following programme of surveys, investigations and design works

(1) Compilation of contour maps with 1-metere intervals, at scale 1:10,000 of an area of:
a) 200,000 - 250,000 hectares in the Herat valley.
b) 60,000 - 70,000 hectares in the Farah valley.
c) $200,000-250,000$ hectares in the Kabul valley.

(2) Compilation of maps of the reservoir catchments at scale $1: 250,000$ 。

(3) Fngineering-geological and hydro-geological investigation of the dam sites and reservoirs with the help of drilling equipment, pits and tunnelling.

(4) Preparation of designs of dams and reservoirs on the Hari Hud, Farah Rud and Kabul tributaries.

(5) Pedological and hydro-geological investigations of the irrigated and irrigable areas.

(6) Preparation of layouts of three typical plots for trial irrigation farms, each 250-300 hectares, one plot in each area of development, at a scale of 1:2,000, with $0.25 \mathrm{~m}$. intervals between contours. On these plots should be designed the systems of field irrigation and drainage in full detail, and specifio indices of quantities of works should be determined.

(7) Preparation of layouts of the irrigation systems, based on contour maps at scale 1:10,000 (with designs of the irrigation, drainage and road systems with installations, preparation of specifications for equipment. and materials, estimation of the main quinttios of work and the costs of project) on areas of:
a) 150,000 hectares in the Herat valley,
b) 60,000 heotares in the Farah valley,
c) 36,000 hectares in the Logar valley (Kabul basin).
d) 76,000 hectares in the Shakar Dara valley (Kabul basin) and
e) 98,000 hectares in the Kabul valley (Kabul basin).

12. Studies relating particularly to Agricultural development: there should include:

(1) Preparation of plans and organization of three model trial irrigation farms, each of 250-300 hectares, and each with an agricultural research station of 15-20 hectares, in the Herat, Farah and Kabul valleys respectively.

These farms and the researab stations will be for demonstration purposes, as well as for the training of national agricultural specialists. 
(2) The operation of the trial agricultural farms and research stations should be supervised by well qualified experts, possibly foreign, for 4-5 years until national staff are trained for this purpose.

(3) Study of the existing system of land use, size of holdings, future conditions of land use, etc.

(4) Study of farm incomes, gross and net value of rarmjng produce, and conditions of oredit, etc.

(5) Survey of roads and other communications.

(6) Study of the whole economic aspect of the areas where irrigation development is planned.

(7) Collection of data of organizational and technical nature.

13. Costs of Further Investigations. To indicate the order of magnitude of the work involved in implementing the above suggestions, it is tentatively estimated that the following servioes would be required: (1) external technical assistance for about 1000 expert-months; (2) equipment, motor transport, eto., to the value of about $\$ 800,000$; (3) on the part of the Government, investment would be required totalling about $\$ 700,000$, of whiah $\$ 200,000$ would be for the salaries of engineers, technicians, administrative and service personnel; $\$ 300,000$ for the construction, maintenance and operation of the trial farms and research stations and their equipments and $\$ 200,000$ to meet local operating costs.

14. Priorities in the Development Recommended. The execution of the developments recommended in this Report, for the Hari Rud, Farah Rud, and Kabul basins, will involve heavy capital investment over a considerable period of years. It is therefore necessary to establish an order of priorities for the proposed stages of development:

(i) First, in all basins, it is important to bring under control the intake and distribution of water, by the construotion of regulating works, with, on lands where drainage is poor, systems of collector drains.

(ii) As between the three basins, the possibilities and prospective benefits appear definitely greater in the Hari hud and Kabul basins than in the Farah Rud. Sinoe the surveys and investigations already made are more detailed for the Hari lud than for the Kabul basin, it is recommended that the order of priority to begin with should bes

Hari Rud (Herat Valley)

Kabul Basin

Farah Pad.

(iii) Development in the Herat Valley will itself have to be done in stages. These may well be linked with the construction of reservoirs as follows:-

Stage 1 Tangi Shah Reservoir

Stage 2 Assarassum Reservoir

Stage 3 All reservoirs - full development. 
There are arguments for building Assarassum Reservoir in Stage 1, and Tangi Shah Reservoir in Stage 2. But at present, on the whole, the balance of advantage appears to lie with Thangl Shah in Stage 1. This question ahould be further examinod, as should also the question of what other reservoirs hould also be built, including those at Salma and Tasrakat on the Hari Fud and at Tangl Azao on the Kawgan tributary, and of what designs and orpacities.

14. Other Recommendations Teahnical and practiosl recommendations appliouble to irrigation development in all basins are summarised below -

(i) Asricultural Recommendations

Without improvement in virtually every branch of orop husbandry, irrigation by itself can bring little lasting benofit. In particular, there will be a need for the adoption of suitable arop rotations, (such for example as ootton/alfalfa); improved cultivation teohniques; more pest control; and the use of fertilizers. The present system of arop-fallow rotations should be abandoned. Wore intensive orop rotations mould include suitable proportion of oash arops, wuch as sugar beet, jute, oil plants, oto., as well as cotton, which can provide raw materials for the further expansion of industries. To improve methods of cultivation, the present use by farmers of primitive implements and draft animals should bo gradually replaced by improved implements operated by tractors.

(ii) Training of Farmers and Farm Credits and Servioes Trainting of farmers in all branches of afrioultural production in Afghanistan is most urgently noeded and should begin as soon as possible. It is not the purpose of this Report to make specifio proposals, but it is suggested that suah a programme should inalude provision for teahnical agricultural and veterinary services to farmers, for study courses in village schools, and for the initiation of seminars, exhibitions, and demonstration plots or farms. The application of new methods by farmers would be greatly faoilitated by a system of farm aredits, e.g. for the aoquiaition of now -quipment, and by the establishment of secial stations, equipped and staffed to carry out speoial kinds of agricultural work, against pryment, or against a share in the prospective orop yields.

(iii) Animal Husbandry

The introduotion of arop rotations with inoreased proportions of pulses and fodder oxops, and the expansion of summer orops, will areate enlarged opportunities for the development of productive animal husbandry.

(iv) Trial and Demonstration Stations and training of Speoialised Staff

The trial farms recommended above under Para. 12 can, as there mentioned, be used to demonstrate new methods to farmers, and to train national agrioultural specialists, as well as for researah. To staff these farms, expert expatriate staff will be required for several years, until national staff can gain sufficiont experience to take charge of them. 
(v) Irrigation

In applying water for irrigation in the field, the present wasteful preotices, such as flooding, should wherever possible be replaood by better mothods, inoluding furrow imsigation. This requires oareful levelling of fields and systematio control of water, according to the requirements of the orops, and considerations of drainage, soil water conditions, Boil reolamation, eto. To achieve this, regulation of flows throughout the oanal systems is essential, as well as control of river flows by reservoirs.

Seepege losses from conals can be reduced by lining the canals with conorete or, less expensively where feasible, with asphelt; the deposition of fine silt can also help in this.

(vi) Cround Water and Drainger Salinity and Land

Reclamation

Where ground water levels are high, e.8. less than $5 \mathrm{~m}$. below the surface; or lands are saline but reclaimable, the introduction of drainage systems is required. Where irrigation is to be extended to now lands in which ground water levels are deeper, the immediate provision of drainage may appear to be unnecossary. But the application of irrigation will itself raise the levels of ground water, with inoreased risks of salinization, and to prevent this, the development of the drainage systems at the same time as the irrigation systems will be desirable, or by sucoessive stages if preferable. Systematio observations of the levels and qualities of ground water, in suitable wells, is very necessary.

(vii) Propraming and Planning

In any one area, it appears very desirable that the improvement and remodelling of lands already under irrigation, and the provision of irrigation to new lands, should be done together. Certainly, the plans and designs for any one area should be comprehensive and provide for both these forms of development.

This combination of purposes is also necessary in the work of the higher planning authorities of the country. If, for example, a national programme provides for the construction of a reservoir for irrigation purposes, it should also cover the construction of a system of irrigation and drainage to use water from that reservoir, with also the corresponding development of agriculture, and the processing and disposal of the crops to be expected. Funds for all these steps should be earmarked, and means to effeot them. 
(vii1) Organisation of Land and Water Use

With the increasing development of national sahemes of irrigation development, it appears necessary to establish a single Covernment authority to deal with all the teahnioal problems of survey, planning, operation and maintenanoe, and the registration and supervision of individual systems. This althority should be organised with the requisite teohnical staff, both at its headquarters and in provinoial centres as required.

NOTES Manj of the fields referred to in the above generel recommendations have already been the subject of projects carried out by FAO under the U.N. Fxpanded Programme of Teohnical Assistance. The Final Reports of those which are especially relevant to the areas covered by the present projeot are listed in Appendix IV.

15. As a first follow-up of the Projeot with wiah this report is conoerned, the Government of Afghanistan requested the U.N. Speoial Fund to oonsider a new projeot which should concentrate in more detailed investigations of the Hari Fud and Kabul Basins. This Project has been approved by the Coverning Counoil of the Speciel Fund, with FAO as the Frecuting Agenoy.

In addition, a further Projeot for a goundwater curvey of the Kabral, Katawas and Bakma areas, has been approved, for implementation by the U.N. Teohnioal Assistanco Administration as Krocuting Agenoy. 


\section{CHAPTER 3 - GENERAL DESCRIPTION OF PROJECT ARFAS IN THE SETIIIG OF AFGHANISTAN}

1. General Information Afghanistan is a mountainous country with a surface area

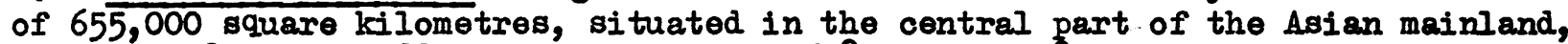
between $29^{\circ} 30^{\prime}$ and $38^{\circ} 31^{\prime} \mathrm{N}$ latitude and $60^{\circ} 30^{\prime}$ and $72^{\circ} \mathrm{O}^{\prime}$ E longitude. The narrow Wakhan strip in the East reaches as far as $74^{\circ} 5 I^{\prime} \mathrm{E}$ longitude.

In the North, Afghanistan borders on the Soviet Central Asian Republios; in the North-East, over a short stretch, on the Chinese Peoples Republic and India; in the Fast and South on Pakdstan, and in the West on Iran. The most important cultural centres are located at high elevations: 0.8 . Kabul at $1795 \mathrm{~m}$. above sea level, and Charni - the country's ancient capital - at $2360 \mathrm{~m}$. Fren the comparatively lower cities of Herat and Kandahar are elevated 930 and $1020 \mathrm{~m}$. respectively above the sea.

Physically, the principle feature of the country is a great mountain mass which divides it, roughly, from NNE to SW, sloping more steeply on the northern side than to the south and west. The ranges of which this is composed are in effect a western and south-westerm extension of the Hindu Kush, the main range of which occupies the north-east corner of the country, with peaks rising to nearly 6,000 metres. North of Kabul, the main range fans out, continuing westwards as the Kuh-i-Baba, which rises to 5,000 m., the Band-1-Bayan and finally the Paropamisus, whioh form the northern watershed of the Hari Bud. All the river basins w1th which this Project is concerned are on the south side of this mountain backbone. South of Kabul is another range, the Safed Kuh, which again reaches nearly 5,000 m. on the Pakistan frontier. The Kabul valley itself descends very steeply below Kabul oity, to as $10 \mathrm{w}$ as $600 \mathrm{~m}$. in the Jalalabad plain, which has a sub-tropical climate, but in the south and southwest of the country vast barren territories extend over some 15,000 square $\mathrm{Km}$., at altitudes of 700 and $800 \mathrm{~m}$. These constitute the Helmand and Bakwa deserts in the south west, and towards the Pakistan frontier, the Reghistan ("country of sand"). Swampy lakes are a feature of the western and south-western frontier country.

The main features of the country are shown on Map No. 1.

The surveys made under the Project cover various parts of the country, mainly in West and South-West Afghanistan, represented by the basins of Hari Rud, Adraskand and Farah Rud, and in East and South-Elast Afghanistan, represented by the basins of the rivers Kabul, Chazni and Nahar.

Though these areas have some characteristics in common, they vary widely in respect of climate, geology, soils, population, land use, roads, vegotation, hydrology and topography.

2. General Geology Considerable parts of the basins surveyed are high alpine and mountainous areas at altitudes from 2500 to $4500 \mathrm{~m}$. Their valley portions are also considerably elevated above sea level, for instance, the Herat valley lies at 900$1000 \mathrm{~m}$. Kabul velley - 1600-1800 m., Chazni valley - 2000-2500 m.3 only the Farah valley does not rise above $800 \mathrm{~m}$. 
The general terrain of the mountainous part of the area, with its peaks, testifies to a relatively reoent lift of the mountain ranges whose origin oan be traced brak to the Tertiary perriod.

Metamorphic and intrusive rooks are prodominant in north-oastern Afghanistan, from Chazni towards the Safed Koh south of Jalalabad, and from Kabul to Panjahir, Mir Somir and Badakshan. Nuch of this metemorphio terrain has Palaezoio elements, and is not equivalent to the true Arohrean Basement Complex of the seismically stable Indian pentinoular.

Crystalline rooke are also present along both sides of the Heri fud in the ObehHerat area, but the high ranges of the greater part of south-western Afghanistan consist of limestones and Flysah, with oconsional intrusive masses. All the higher summits along the upper Farah Fud consist of Cretaceous limestone.

In the contral Farah Fud, along the Adraskand around Shindand, and in parts of the contral Hari fud, there is an extensive development of Iower Tertiary voloanio roaks, with intrusive granodiorite and gabbro. Three of the dem sites with which this report is concerned are located within these voloanios.

Neogene conglomerates are prevalent not only in the lower lving reglon of Farah and Herat, but ocour throughout muah of the central hishlands, up to 3,000 metres elevation. Similar deposits ocoupy muoh of the Kabrul besin, where they oocur as terreoes partially swemped by reoent alluvium.

Much of south-eastern Afghanistan consists of Cretaceous to Lower Tertiary Flysah, with assooiated Cretroeous-Booene limestones.

Southern Afghanistan is interseoted by major faults along which transcurrent movements heve taken place. These are desortbed in Volume. II. The Chaman fault extends from noar the Makran into Baluahistan and Afghanistan as far as near Mukur. Its certain length is $700 \mathrm{Km}$, but a northern extension probably brings it past Charni almost to Kabul.

\section{General Climate and Hydrology:}

(i) Climater The location of Afghanistan in the heart of the Asian continent, and its remoteness from the ooeen, result in intense heating and comparatively quiak oooling of 1 te land surfece. In generel, the country is chareoterized by dryness of the air, low aloudiness, plenty of sunshine, Iow precipitation, hot summers and relatively cold winters. This areates a continental olimate, with sherp differenoes of day and night temperatures, and a considerable range of temperature over the yoar.

The determining olimatio factor in any one locality is not the latitude or longltude, but the altitude above sea levels the very topography of the country determines the variety of olimatio oonditions. In the Alpine areas of the besins (over $4,000 \mathrm{~m}$. In some cases) the winter is severe and long, up to 9 months; the summer is short and has an average air temperature below $+5^{\circ}$. Agrioulturally speaking, conditions range from areas such as those above $3,400 \mathrm{~m}$., in the Kabul besin, where it is hard even to grow barley, to the lowlands where sugar cane, citrus Iruits and date pelms are oultivated ( $650 \mathrm{~m}$. in the Farah valiey). In the Kabul basin, at 1,800 m., the average air temperature is $+24^{\circ}$ in July and $-4^{\circ} \mathrm{C}$ in Jamuary. In the plaing of the west and south-oast (Herat, Farah and Chaznt), the average air temperature in Jamary is above zero, rising to $30-35^{\circ} \mathrm{C}$ in July. 
Precipitation is low, being very unevenly distributed through the year and depending also on the elevation. In the lower parts of the Herat, Farah and Chazni valleys, it is 150-250 mm per anmum. It is higher in the mountains, where it takes the shape of snow in winter and of shower rains in spring. In the Kabul area, affected by the monsoon from the Indian Ocean, anmal precipitation reaches $400 \mathrm{~mm}$.

(ii) Hydrology: A precise appraisal of the water resources of a river depends on a long series of records, based on regular measurements of flows. As the study of the water and sediment discharges of the majority of the Afghan rivers has only just been started, the solution of any hydralio problem in the country must be based on short hydrological records, or on analogues from other rivers with 3 to 15 years of observations.

In estimating the river runoff in the basins surveyed, generally accepted methods of computation have been used, leading to determinations of the mean normal runoffs, anmual runoff fluctuations, seasonal runoff distributions, maximum and minimum discharges, sediment discharges and other hydrological elements, for each proposed dem site on every river surveyed. Such estimates of river runoff are given in the various seotions of this volume for every basin, and are described in detail in Volume III on Hydrology.

4. Soils of Afghanistan The soils of the main farming areas within the river, valleys and foothills can be divided by their texture into four principal categories:

1) Heavy loams of the bottom lands;

2) Medium loams of mountain slopes (sierozems);

3) Loess-like loams of the foothill areas (northern part of the country);

4) Cultivated dry-farming casis soils.

The heavy loams are usually connected with water-logged (or marshy) river bottom land, mainly in areas used for rice growing.

Humus Soils with a significant amount of organic matter are met only among the heavy loams. All the heavy soils have the highest alkalinity and carbonate content.

Medium loams are common sierozems. In their skeletal part they have much stone, passing into pebbles or finer deposits, along steep slopes. These loams occur on patches of piedmont and talus origin.

The alluvial soils in the river bottom lands are also sierozems, but have more hum us and are less stony.

All the medium and light loams are characterised by a higher content of particles of 0.1-0.05 m. size, which testifies to their deposition by fast water flows. Their common feature is a good permeability and a quick capillary action. These qualities are in some respeots valuable for farming purposes, especially in irrigated agriculture.

The easy permeability accounts for the desalinized state of the cultivated irrigated soils. The bottom land medium loams usually have medium humus content, which indicates their cultivated condition. On the other hand, little cultivated loams sierozems - on the piedmont patches are often saline and short of humus to such extent that they more resemble rock than soil and could be named desert sierozems. 
If they occur in the valley bottom lands the medium loams pass into sandy loams of medium humus content.

The man-made soils of the cases stand quite apart from the others. They could be called "cultivated irrigated soils", as they have not gone the way of natural development, and their structure changes with reclamation.

The arable soils of the Herat casis (900-1100 $\mathrm{m}_{0}$ ) as well as those of the Kabul area (1600-1800 $\mathrm{m}_{\bullet}$ ) and the soils of Sar-i-Cheshmeh (along the Kabul area - $2500 \mathrm{~m}_{0}$ ) fall into the same category of medium loams with medium humus content, they might be called sierozems. These sierozems vary in different areas in their degree of stoniness, in the thickness of the layer affected by the soil-forming processes, and in the extent of salinity. In parts, they turn into solonohaks, but the total area of the latter in Afghanistan is not very large, except in the solonchak marshes of Seistan.

The "cultivated irrigated soils" near large centres and towns are the deepest and best arable soils. However, these soils are map-made. In their natural state all the soils of Afghanistan could be rather called rock-soils. In the southern stony deserts, plants grow on the sierozem sand barely covering parent outcrops.

The attached maps Nos. 2 and 3 should be considered as first attempts at compilation of soil botanical maps of Afghanistan. This work would require in the future detailed investigations using more precise cartographical materials, now under preparation in the country. These maps were borrowed from the book "Agricultural Afghanistan" by N. Vavilov and D. Bukinich.

A detailed desoription of the soils surveyed in the valleys of Herat, Farah, Adraskand, Kabul and Chazni is given in respective chapters for each of the basins in this Volume, and also in Volume IV.

6. Vegetation and Animals Although there are some fine forests in the high mountrin ranges, especially to the north and north-east of the country, with the fauna to be expected under such conditions, the areas with which the surveys were concerned are remarkable for their sparseness of vegetation and the paucity of animal life. The upper catchments are often bare rocky mountains, with almost no soil cover and very little vegetation. In the steep ravines, shrubs and occasional trees appear, while on the ridges lower down there is thin soil cover with correspondigly more vegetation. Shrubs at these heights include wild olive, acacias and mimosas, while lower down there are more herbs especially of the natural orders Labiatee, Compositae and Umbelliferae. On unirrigated land, camel thorn, tamarix and mimosas occur, with the other vegetation usual on semi-arid lands, including many spiny plants.

While this general pattern applies to virtually all the areas surveyed, there are differences between species and associations in the different valleys, according to microclimatic and soil changes.

Round the villages and in populated areas generally, cultivated trees include pines, poplars, willows, oaks and various fruit and nut trees, as well as grape vines and mulberries which are grown in some areas for sericulture as well as for their fruits. Peasant farmers have created what are virtually small oases in some of the deeper river valleys, building up and preserving the soil to grow cereals and vegetable crops. 
7. Population According to the latest estimate, the country's population exceeds 13 million, of whom about 9.5 million are occupied in agriculture or animal husbandry, some 2.5 million engage in nomadic or semi-nomadic raising of livestock, while the remainder, over I million, are townspeople engaged in commerce and industry.

Afghans are estimated to constitute some $60 \%$ of the population, Tith Tajiks (30\%) and Uzbeks (5\%) predominating among the other racial groups; the principal relizion is Islam, the majority being Sunnites of the Hannifite creed.

The population is very unevenly distributed, the controlling factor being the nature of the terrain and the variety of natural conditions. While vast areas of mountain and waterless, barren arid lands remain virtually unpopulated, the Kabul and Kandahar oases, the Herat and Farah valleys, Mazar-i-Sharuf, Baghland and Kunduz in the north, as well as other areas with fertile lands and ample water are densely populated at a density said to equal that of the U.S.A. Thus, unofficial data show 2.6 million in the Kabul basin (including 300,000 in Kabul), 1.3 million in the Herat Province (including 160,000 in Herat), 300,000 in the Farah Province (including 15,000 in Farah), around 600,000 in the Gazni Provibce (including 20,000 in Chazni).

Particularly in the areas surveyed, agriculture and livestock industry are the mainstay of the economy. Besides employing the vast majority of the pouplation, these industries create $80 \%$ of the national gross product, while they supply, chiefly in the form of animal products (karakul, sheepskins, wool, carpets etc.) some $95 \%$ of the country's exports.

8. Roads and Communications The principal cities and towns in the basins surveyed, Kabul, Herat, Farah, Chazni, Shindand are connected by the main national circular highway, which runs in effect round the country, 2,700 Km in length. These centres are also linked by another main road which crosses the country from east to west, from the Khyber pass through Kabul to Herat, wi th a spur running southwest from Qal oh Shararak to Shindand, thus connecting the Pakistan road network with that of Iran. Often steep, winding and rough, this road oould be a main supply route but it is unsuitable for heavy traffic at present; it is closed during winter and in spring is often unmotorable. (Map No. 1)

When the east-west route has been improved, these two main routes could be used for transporting all the material required for irrigation development in the basins under review. It must however be borne in mind that while these will serve as the main routes, access roads from them to the proposed sites for dams and power works will also be needed.

The majority of the populated centres in the valleys are linked to the main routes by dirt roads. Especielly in the mountain stretches, these are often steep, narrow and with poor surfaces and many temporary bridges. They are in many cases, and at certain times of the year, quite unfit for motor transport. Nonetheless, an ever increasing fleet of trucks provides the main means of transporting heavy materials for building etc., as well as equipment and bulk consumer goods. The nember of passenger buses is also increasing steadily throughout the country and the big cities have their own motor fleets owned by "shirkets", local joint stock companies with Government participation. In the remote areas, and within the country in general, pack animals still carry a major part of the goods traffic, especially in the Hari Pud, Farah Rud and Chazni basins. 
Kabul has a modern international airport connected with many world air routes, and soheduled internal flights conneot the capital with the major provinoial centres. Radio and line telegraph and telephone systems link the oities, and there are local telephone networks, and postal services in and around the capital and the provinoial and distriot centres.

9. Land Use Under Fristing Conditions Land irrigation under existing conditions in the surveyed basins is mainly based on the limited supply of surface waters that can be used under the present natural regime of the rivers, wi thout water control, and, to an insignificant extent, on the use of ground water. Flows available in the low periods - during the summer, autumn and winter seasons - are entirely takon for irrigation. However; over 50\% of all the yearly runoff on every river occurs in the spring period (see Table 2). The passage of the flood is characterized by high but brief peak discharges, and full usage of the flow during this period for irrigation is possible only if it is controlled by storage in reservoirs.

A characteristic feature of the irrigated farming in the valleys surveyed is the wide variety of field crops. However, the main orop in the valleys, as in the majority of the country's areas, is wheat. Considerable acreages are sown to barley (especially in the Herat valley), maize, alfalfa, clover, pulses; relatively amall areas are grown with rice and cotton. Vineyards and orohards, regeteble gardens and melon fields occupy farmstead plots near the villages; something like 100 different plant species are grown for one purpose or another.

Another feature of land use in the valleys is the crop-fallow system. The main reason for this lies in the small availability of free lands, fit for irrigation, and the lack of sufficient water under the present conditions wi thout water control. One year of cropping is usually followed by 2 to 4 years of fallow.

The crop lands belong in part to omer-cultivators, and in part to big landowners who, as a rule, rent the land out to peasants. The peasants' plots are very smell, and there are only fow farms excoeding one heotare. The irrigated plots are divided into well-levelled aheaks; flood irrigation is the rule, irrigation by furrows being only rarely met with.

There is no strictly established system of crop rotation, but the peasants have a cortain $\operatorname{cod} \theta$ of rotation rules to which they adhere in sowing individual crops. Wheat and barley are rotated rather freely, but cotton and rice are usually sown after alfalfa and pulses.

Although mineral fertilizers are almost unknown to the Afghan peasant farmer, earth fertilizer, with an admisture of dung, is used wherever it can be obtained. It is applied anmually, often in comparatively largo quantities, but mainly on the intensively cultivated plots near the villages. The small soele of peasant farming operations, and the dispersel of their holdings, present big obstacles to the application of modern farm machinerys at present virtually all agricultural work is carried out by hand or with draft animals. Bvidently, the whole problem of the size of holdings, and possibly of the land temre system, will need to be tackled before modern farming can be introduced on a large scale.

More detailed information on agriculture is given in the respective ohapters later in this Volume, on land use and farming practices in the seotions dealing with the various basins with which the Project was conoermed. 
10. Summary of Survers Completed Below is a brief description of the main surveys carried out by the Projeot Team specifioally for each basin.

\section{HARI RUD BASIN}

\section{a) Topography}

Topographical surveys were carried out and maps prepared for the proposed storage dam sites of Tasrakay, Assarassum, Salma and Tagau-Kaza, on the Hari Pud, and Rangi Shah, on the Kawgan river, a left bank tributary of the Hari lad.

Besides, surveys were carried out and maps prepared of the sito for a diversion weir on the Hari Bud, and a "typical plot" wi thin the Herat valley.

b) Geology

Geological investigations were conduoted of all the dam sites on the Hari Rud and its tributary Kawgan, Tasrakay, Assarassum, Salma, Pul-i-Sherkhaj, Tagau Kaza, Marwa, Tangi Azro and Tangi Shah. Geological reports and mape were prepared for five of these dam sites. A geological map was compiled for the north-western portion of Afghanistan, including the Hari Had Basin.

\section{c) Soils}

Soil surveys were carried out on a total area of 410,770 hectares in the Herat valley. Thers were prepared a soil report and maps of the soils, land classiflcation and land use. Chemical analyses were run on soil and water samples, and the physical properties of the soils were investigrted.

\section{d) Hrdrolost}

The hydrologionl characteristios of the Hari Rud and Kawgan were described for each proposed storage and diversion dam sites: Assarassum, Tagau Kaza, Tangi Shah and Marwa. Ceuging stations were constructed at Checkcheran, Tagau Kaza and Herat, on the Hari Fud, and at Pangi Azao and Langar, on the Kawgan river, and regular observations were taken.

\section{FARAH RUD BASIN}

\section{a) Topography}

Topographic surveys were made and maps were prepared of the potential storage dam sites of Lashkagar, Alikinai, and Bakshabad, on the Farah Bud.

b) Geology

Geologioal investigations were made of the three dam sites at Lashkagar, Alikinai and Bakshabad, on the Farah Fud, and of the adjoining areas. basin.

A report and a geological map were prepared of the central part of the Farah fud

\section{c) Soil Survers}

Soil surveys were carried out on a total area of 50,900 hectares in the Farah valley; soil report and maps of soll types, land classification, and land use were prepared. Soil and water samples were analysed covering the entire surveyed area, and the physical properties of the soils were investigated.

\section{d) Hydrology}

Hydrological aharactexistics were described for each of the proposed storage dam sites on the Farah Pud: Iashkagar, Alikinai and Bakshabad. Gauging stations were built and equipped at Petchi-Tangi and Daulatabad - on the Frarah Rud - and on the Malmand tributary of the Farah Fud on its left bank; and regular observations were taken. 


\section{KABUL BASIN}

a) Topography

Surveys were carried out and contour maps prepared of the proposed storage sites at Tangi Saidan on the Bala Maidan (upper Kabul river), and at Kajao on the Logar river.

Simplified surveys were also carried out at two dam sites on the Panjshir and four on the Chorband.

b) Coology

Geological surveys were carried out and reports and maps prepared for the storage dam sites at Tangi Saidan and Kajao. A brief geological description was also prepared for the proposed sites on the Panjshir and Chorband rivers.

c) Soils

Soil surveys were conducted in the valleys of Logar, Chorband, Panjshir, Shakardara and in the Kabul area, on a total of 238,000 heotares. A soils report and maps of soil types, land classification, and land use were prepared. Chemical analysis of soil and water samples was carried out for the surveyed aseas.

d) Hydrology

The hydrological characteristics of the Bala Maidan, Logar, Chorband and Panjshir rivers at the sites of the proposed storage dams at Tangi Saidan, Kajao, Ushturshar and Gulbahar were described. A gauging station was set up on the Iogar river at the proposed Kajao dam site.

\section{GHAZNI PROVINCE}

a) Topography

Office processing was done of the aerial photos of proposed dam sites on the Chazni river, and later trips were made for inspection of these sites.

b) Geology

Along with the geological reconnaissance survey of the Nahar valley and Katawaz area, a hydrogeological investigation was also carried out, which resulted in a reconnaissance report on the ground water conditions in this area of the country.

c) Soils

Soil surveys covered an area totalling 878,290 hectares, out of which:

Chazni valley

Valley of the Jilga river (Ghazni tributary)

250,000 ha.

Nahar valley

139,990 ha.

Katawaz area

123,400 ha.

Dil area (around Ab-i-Istada lake)

54,900 ha.

A soils report and maps were prepared of soil types, land classification, and land use. Chemical analyses were made of soil and water samples taken from the entire area, and the physical properties of soils in the areas were investigated.

d) Hydrology

A hrdrological report was prepared on the water resources of the Chazni and Naheir rivers. 


\section{ADRASKAND BASIN}

\section{a) Topography}

A map was prepared of the Adraskand basin, and office studies were made to find possible storage dam sites, using aerial photographs and contour maps.

b) Soils

Soil surveys were carried out on a total erea of 155,000 hecters, covering the middle part of the Adraskand valley - above and below Shindand.

There were compiled a soils report and maps of soil types, land classification, and land use.

Chemical analyses were made of soil and water samples, providing a coverage of the whole surveyed area.

A brief report was prepared on the physical properties of the valley soils.

c) Hydrology

A hydrological report was prepared on the water resources of the Adraskand river.

Two gauging stations were set up: one on the Adraskand river and the other on the Rud-i-Ghaz (Northern Afghanistan) - on the highway bridges.

\section{KHASH RUD BASIN}

Based on the aerial photographs, the Engineering Geologist prepared brief conclusions as to the utilization of the Khash Rud Waters for irrigation of part of the Balkwa valley lands. (See Volume Two, Section I, part IV).

\section{GENERAL -}

Besides the above activities in each individual basin, the hydrology team installed eleven totalising rain gauges in the mountainous and desert areas. These cover the basins of the following rivers: Kabul, Kunduz, Hari Rud, Farah Rud, Adraskand, Charni, Helmand and Murghab. In the majority of cases, they enabled preliminary data to be obtained of the precipitation during the cold period of 1962-63. In all, eleven river gauging stations were set up. Of these, five were equipped with water level recorders, four with cable ways, and all eleven with staff gauges. Four of the stations are fitted on bridge piers. All have a fixed zero of gauge expressed in absolute or relative values; their bearings were determined, as well as distance from the river mouth, catchment areas above each station, their opening dates and other information needed for carrying out regular hydrological observations and measurements.

A hydrological yearbook has been prepared for all the stations set up by the Project, for the period from their inception till mid-1963. Observations and measurements at all these gauging stations are contiming.

\section{DESIGN}

An interim plan was prepared for the reconstruction of the irrigation systems in the Herat valley, over a total of $131,000 \mathrm{ha}$. This includes recommendations for implementation of the reconstruction in stages, and gives preliminary estimates of the costs, and certain technical and economic indices. Sohemes for irrigation development covering some $50,000 \mathrm{ha}$. in the Farah valley and a total of 107,000 ha. in the valleys 
of the Kabul besin have also been propared.

Preliminary deaigns havo also been carried out for run-off regalation of certain of the rivers. These include desi gens of dams and reservoirs, mainif for irrigation development; at the same time the hydroporver potential of oertain dem sites on each of the rivers was established.

As a general rule, all field materials were processed, and design work was oarried out, in Kabul, every effort being made to integrate the work of the different experts involved.

Besides the survey activities, much work was done by the soils laboratory, the soil chemists making over 7,000 analjais on 952 soil samples from various parts of the country. The soil chemists agreed that there will be a noed within the noxt for jears, of a foreign expert to supervise the work of the laboratory, and espeoially to contime theoretical and practioal training of the looal specialister as there is still a shortage of gualified personnel who could assume the responsibility of running the laboratory and directing its operations. 
CHAPTER 4 - METHODS OF FIFHD SURVEYS AND OFFICE WORK

The field and office work for the Project was carried out by standard and generally accepted methods, suited to the background conditions provided by previous surveys, if any, and with very limited statistical data available.

The organization of the field and office processing work is described in Chapter 1 of this Volume.

Below is given a brief summary of all the methods on which were based the topographical, geological, pedological and hydrological investigations of the Project.

1. Topographic Surveys Topographic Surveys were mainly concentrated on water storage sohemes, although some surveys were also carried out for the purposes of irrigation design.

Small scale mapping, at scales smaller than 1:10,000, was done photogrammetrioally, plotting being carried out on a Zeiss stereoscope. The average scale of air photography used was about 1:50,000. All photogrammetric mapping can only be considered to be of a reconnaissance standard, producing only first estimate data for engineering designs.

Vertical control for air photographs was normally effected by altimetry. Horizontal control was either taken from advance copies of the Geological Survey maps, or established geodetic points, or was based on local triangulations and traverses. All surveys for mapping at scales 1:10,000 or larger were carried out on the ground by conventional survey methods. For the most part the mapping was only referred to a local datum. In areas where the absolute datum could be economically tied in, connections were made by spirit-level lines.

The Project obtained its own sets of air photographs of those areas where large scale investigations took place, namely the Farah, Herat, Katawaz, Adraskand and Kabul regions. As time did not permit field ahecking of photogrammetric mape, little can be said about expected accuracies. If development proceeds on any of the proposed projeots additional mapping will have to be carried out.

2. Engineering Geolog Until recently, Afghanistan was little known geologically except for traverses made by Griesbach, Hayden, Fox, Bouie, Tromp, Popol and Hunger. Systematic geological survey work is now being undertaken in the north of the country with the assistance of Soviet scientists, and in the east by the German Geological Mission in Afghanistan. The greater part of the areas with which the Project was concerned had, however, been little explored, and it was necessary to make photogeological studies in order to form a regional structural background. Ground reconnaissance was carried out over the routes which were travelled. Particular sites and reservoir basins were selected from the air photographs, and these were then visited on the ground. If a site was considered to be feasible for dam construotion, a detailed survey on the scale of 1:2,000 or 1:2,500 was made by the topographical group. These maps were the basis for geological mapping of dam sites, while the air photographe were used for reservoir studies. It was only towards the end of the work that the Government topographioal maps on the scale of 1:50,000 were available over parts of the river basins under stady. 
3. Soil Survey and Land Classification The investigations on the soils and land use of the project area had four objectives:

- Classification and reconnaissance survey of soils according to their morpho-genetic characteristics; the final product of which is a base soil map.

- Land classification based on the suitability of soils for irrigation. This results in a land suitability map.

- Description of land use under existing conditions.

- Evaluation of the possibility of developing irrigation on noncultivated areas.

A soil map and a land suitability map were made of the various basins covered by the project. The total area surveyed amounts to over 1.7 million hectares. The maps were based on aerial photographs at the scale of 1:50.000 or 1:76.000. The final maps are at the scale of $1: 100.000$.

The soil survey was based on profile examination along cross sections of the valleys or basins. Various laboratory determination as detailed in Vol. IV were made in addition to the field work.

The land capability map is an interpretation of the basic soil map. It shows the distribution of soils according to their general suitability for irrigation. All. surveys made were on a reconnaissance standard.

\section{The Soil Maps}

The various basins survveyed are located at altitudes of from a few hundred meters in the Farah valley to over 2,000 m. in the Chami valley; their geology, vegetation, climate and soils vary considerably. In view of this it was decided to have a separate soil legend for each basin. The various legends have, however, much in common and are based on a associations of groups of soils, with some reference to characteristics of the soils which are highly important for irrigation, such as texture of the parent material, salt content, stoniness, or natural drainage. The legends for each basin are briefly described below; a more detailed description of the mapping units and representative soils is given in Volume IV of the Report, "Soil Survey and Land Classifioation".

\section{Land Suitability Maps}

From the basic soil map, land suitability maps were made at the same scale. The suitability olassification for irrigation is based on internal and external soil charactertistics which are significant for this purpose, such as texture and thickness, nature of the underlying material, stoniness, permeability and water-holding capacity, salinity, erosion, slope and flood hazard.

A uniform classification was used for the various valleys. It does not mean, by the way, that the same irrigation techniques can be used for the same class in each basin. Local conditions of climate, crops, water availability, farmers' ability, and presumably, other economical factors have to be taken into consideration. However important, soil is only one faotor of orop production and agricultural development, and the only aim of the suitability classification is to show that soils in one class have approximately equivalent potentialities under irrigation. 
Six olasses, varying from land most ouitable for irrigation to the non-irrigable land were established. The olesses wore sub-divided into sub-classes according to the nature of the limitations of the land use under irrigation.

Four sub-classes wore usually separateds

A - Sub-class of salinity.

S - Sub-class of texture, thickness, or permeability.

$T$ - Sub-class of topographical conditions and erosion.

W - Sub-olass of natural drainage, water table.

\section{Iend Classification Trpes}

Class Is Verr suitable for irrigetion - deep medium textured soils, good permeability and water-holding capacity; no salinity; high fertility status; no erosion, no water table or flood probleas; flat or gently undulating topography.

Clase II: Moderately autable for irrigation: The soils have a lower oapability than Class I soils, due to moderate limitations in relation to one of the abovemontioned factors. They may require a limited amount of work - land levelling including benoh levelling - wind or water erosion control - speolal tillage operation - removal of rooks, trees, - high quantities of fertilizers - salinity control.

Class III: Marginally suitable for irrigation - The soils require a very special and usually expensive management, due to major limitations of their use under irrigation. they may require extensive work in levelling a rough micro-topography, or terracing on steop slopes, or control of salinity and alkalinity. Some soils of this class have a very low water-bolding capaotty due to a coarse texture or shallownese, or a very low fortility tatus.

Class IV: Non-arable land. Not suitable for irrigation, except under special conditions - The soils are not suitable for annual crops, due to shallowness, slope, flood hazard, natural drainage, or salinity. They may be irrigated under special conditions such as abundant water supply, or proximity of densely populated area, and should be used in accordance with their capacity: e.g. for perennial pasture, or forage, production of firewood, eto.

Class V: Non-arable land: undetermined suitability for irrigation - The limitations mainly due to salinity, alkalinity or topography are so important that under the present conditions the so1ls do not seem suitable for irrigation. Further studies are erentually needed to evaluate their capability for irrigation, especially sprinkling irrigation.

Class VI: Non-irrigable land - This class includes hilly and mountainous areas, river wash, stream beds, extremely rooky or gravelly areas, sand dunes, marshes, salt and alkali flats.

4. Hrdrological Investigations Field hydrological investigations involved the - stablishment of permanent gauging stations at points where dam sites were chosen for construction of reservoirs, and the observation of discharges and water levels at these -tations. All the stations were provided with staff-gauge observers.

At stations without level recorders, water level observations were made twice a day (mornings and evenings); where recorders were installed, staff observations were made once daily, and record rolls were changed every 30 days. 
The measurements of velocities and stream depths, as well as levelling work and selection of samples for silt-charge testing was periodically done by visiting specialists.

All the records at the gauging stations were kept in the Persian language (Farsi).

The completed rolls and observers' water level records were oolleoted by the visiting specialists once every two-three months. The observers' records were translated into Bnglish and analysed, and thon the daily water levels were computed and compiled in annual tables. Discharge curves were based on water levels and discharges, and from them the daily discharges, and the monthly and annual run-offs, were computed.

Because of the very short series of hydrological observations, the data observed at the stations set up under the Project were not sufficient to meet requirements, since it was necessary to make computations for hydrological desoriptions covering a considerable period of years. In this connection, use was made of hydrometrio materials of observations and measurements conducted by other agencies in the basins of the Farah Rud, Kabul and Helmand rivers. Therefore, all the 24 hydrological descriptions were computed on the basis of analogues, with the help of mathematical statistics, through the use of approximate methods, as described in Volume III Hydrology.

Every hydrological description includes the calculations of normal annual run-off, annual run-off fluctuations, maximum discharges, minimum discharges and the mean annual sediment discharge.

The expression a "year of X\% probability" is discussed in Volume III - Hydrology Chapter 5. In effect, in this Report it is taken to mean a year such that its discharge (whother mean, maximum or minimum) will probably be reached or excoeded in $X$ years out of 100 . For example, a year of $75 \%$ probability is a low year, belor the average; a year of $20 \%$ probability is a high year above the arerage.

5. The processing and appraisal of all the field records was done, as a rule, in Kabul, in consultation between all concerned in the various aspects of the Project. 
SECTION II - BASIN OF HARI RUD

CHAPTIAR 5 - DESCRIPTION OF BASTN

1. General Information The Hari Bud rises in the mountains of Central Afghanistan, its principal watersheds being the Paropamismus mountains and other westerm ranges of the Hindu-Kush. It is formed near the village of Shalthin by the confluence of several mountain streams, which flow down the slopes of the Kuh-i-Baba range, from sources at altitudes of about $4000 \mathrm{~m}$. The Hari Rud is one of the main rivers of Western Hindu-Kush. In its upper and middle reaches it flows westwards as far as the village of Kohsan, some $560 \mathrm{Km}$. from its source. It then turns northwards; for some $90 \mathrm{Km}$. it forms the boundary between Afghanistan and Iran, and thereafter the boundary between USSR and Iran; in these reaches the river is called the Tedjen.

The Hari Rud basin is very extensive; its area within Afghanistan is about $39,300 \mathrm{sq.km}$. Its width fluctuates from 40 to $100 \mathrm{~km}$. Some $75 \%$ of the catchment areas are below $1200 \mathrm{~m}$. and runoff from these areas is very small.

The tributary system is better developed on the left-bank of the river. The main left-bank tributary of the Hari Rud within Afghanistan is the Kawgan river, about $260 \mathrm{~km}$. Iong, whose catchment is $7820 \mathrm{sq} . \mathrm{km}$.

The main right tributary is the Korrukh river, flowing into the Hari Rud a few lkm. upstream of Herat. The catchment area of this tributary is $1720 \mathrm{sq.km}$. and its length is $95 \mathrm{~km}$.

Within Afghanistan down to the village of Obeh the river flows in a mountain valley whose slopes are partl cultivated, or used as pastures. Below Obeh, and especially after its confluence with the Kawgan, the basin of the Iriver widens out to form the valley of Herat, one of the most populated in the country, with welldeveloped irrigated farming. The Herat valley is irrigated with soores of canals having independent intakes from the river. The canals vary in length from 2 to $40 \mathrm{~km}$., and have discharge capacities from $100 \mathrm{l} / \mathrm{sec}$. to $6 \mathrm{~m} / \mathrm{sec}$. Downstream of Herat, which stands at $930 \mathrm{~m}$. above sea-level, as a result of extensive water diversion for irrigation, there is no river run-off, as a rule, during the low water season.

Everywhere in the Hari Hud valley, especially upstream of Herat city, the slopes are cut by numerous streams which flow intermittently. When rainstorms occur, these send down flows laden with mud and shingle, which may reach $50 \mathrm{~m} / \mathrm{sec}$, and wich often cause considerable damage to farmsteads, destroying the irmigation canals and ruining crops. In individual years, vast debris-laden floods often swoep away human habitations, especially those of nomads, with loss of human life and livestock. For instance, in the spring of 1963, debris flows in the Hari Rud valley caused over 100 human deaths and the loss of several hundred head of cattle.

2. Climate of the Basin The monntainous terrain with deep-cut valleys and relatively high watershed ranges, creates a great variety of climates in the basin, determined in detail by the elevation above sea level and relief orography. In this respect as well as in topography, the basin can be divided into the following three zoness

i) Plains and foothills; 
ii) Medium-high mountains with altitudes of 1000-2500 m•;

iii) High mountains.

Each of these zones has its own diversity of local climates.

a) Air temperatures

In the zone of plains and foothills, the mean monthly air temperature over the entire year stays above zero. The coldest month is Jamary, with a mean monthly air temperature over many years of about $3^{\circ} \mathrm{C}$; the warmest month is July $\left(30^{\circ} \mathrm{C}\right)$. Filgh temperatures (above 250) contime from mid-Niay till mid-September. In the spring and. autumn, night frosts occur. Sometimes in winter the temperature falls to - $15^{\circ} \mathrm{C}$.

In the second zone, particularly in its upper part, the seasons of the year are rather well pronounced. Mean daily temperatures range over $20-25^{\circ}$ in the summer. In the upper part of this zone the three winter months have a mean monthly air temperature below $0^{\circ} \mathrm{C}$.

In the high mountain zone of the besin, the cold season lasts much longer. The winter with rather hard frosts lasts 4 to 5 months. Here in the summer mean monthly air temperatures do not reach $20^{\circ} \mathrm{C}$.

As there is only one meteorological station in the basin area (that in Herat City), the description of climate is based mostly on estimated figures.

Table 6 gives estimated air temperatures for various altitudes in the basin, as well as the actual temperatures taken at the Ferat Station.

TABLT 6

MUAN MONTHLY AIR TGMPURATURES IN HARI RUD BASIN

Areas and Mean Monthly Air Temperatures (in degrees Centigrade)

altitude Jan Feb Mar Apr Mar Jun Jul Aug Sep Oct Iov Doo

Mean anmal

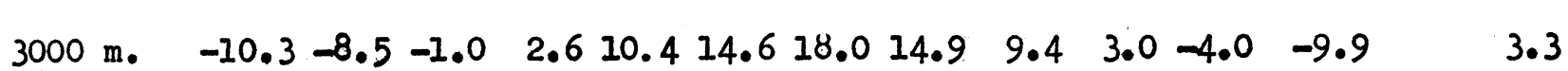

Tangi Arao

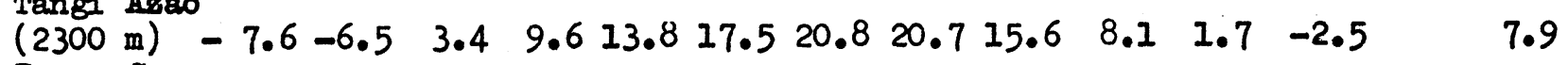

Tagau-Caza

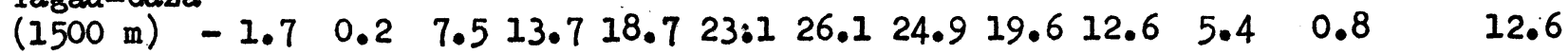

Herat

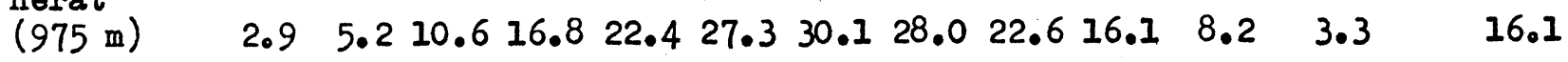

It can be assumed that in the remaining parts of the river basin, downstream of Herat, the air temperatures are near those of Herat. 
b) Precipitation

In all the high mountain zones rainfall occurs only during the period NovemberMay. The dry period lasts from June to Ootober, when rain falls only rarely.

In the lower part of the basin, precipitation usually occurs as rainfall; when snow falls, it usually melts in a few days.

To indicate precipitations in the zone of plains and foothills, Table 7 gives data collected by the Herat weather station:

TABLE 7

HERAT CITY - MEAN MONTHEY PRECI PITATION

Mean Wonthly Precipitation in MM.

Jan Feb Mar Apx Max June July Alsg Sept Oct Nor Deo Total for year.

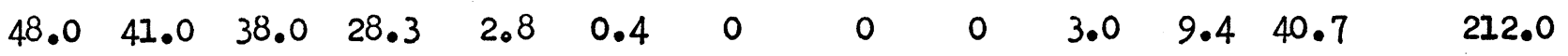

An indication of the precipitation in the basin's upper zones is given in Volume III (Hydrology). This volume includes a sketch map of precipitation in Afghanistan, as well as one-year data on precipitation in the medium high-zones of the rivers of the country, collected with the help of totalising raingauges set up by the Project's hydrology team. In the mountain areas of the basin, that is where the run-off originates, mean anmual rainfall would appear to be $300-400 \mathrm{~mm}$.

c) Evaporation

Relatively high temperatures, small rainfalls, and low humidities create the conditions for intense evaporation, especially in the lower zones. Unfortunately, there are no available observed data on evaporation from water surfaces in areas of possible reservoir construction: Assarassum, Salma, Tangi Azao and Tangi Shah. The Hydrologist of the Project therefore made special estimates of evaporation rates, as given in Table 8.

TABLE 8

HARI RUD - ESTTMATID WWAN MONTHLY EVAPORATION FROM WAYER

SURFACH - IN MILIIMETTRES

Name of Area

Assarassum

(or Salma)

Tangi Azao

Tangi Shah

Herat

Jan Fe

eb Mar

Apr May

70

$50 \quad 110$

130160

$\begin{array}{lllll}60 & 80 & 120 & 140 & 180\end{array}$

$\begin{array}{lllll}30 & 40 & 100 & 120 & 150\end{array}$

$\begin{array}{lllll}70 & 80 & 130 & 140 & 190\end{array}$

$\begin{array}{lllll}70 & 100 & 140 & 160 & 220\end{array}$

Jun

Jul

Aug Sep Oct Nov Dec

Yearly

Total 
Betimated evaporation values should be considered approximate, as a mumber of assumptions were made in their determinations for example, it was assumed that the air humidity at all the places listed is identioal with that at the Herat meteorological station. Such an assump lon is liable to cause some ermors in the results, however, the estimated values should be reasonably close to the actual ones. This conolusion is besed on analysis of the air humidity for the weathe stations at Herat, Kabul and Chami, loosted in different parts of Afghanistan and at different heights.

3. Flore and Faung The Harl Hud basin, in common with most of Western Afghanistan, has extremely limited vegetation and animal life, largo on account of the extreme climatic and topographioal conditions. Such as there is, shows the vertical zonality usual in areas of rapidly changing altitude. Vegotation in the watershed areas, which carry no resident population, retains its primitive character, but in some of the higher rocky mountain areas there is virtually no plant life at all.

The middle zone, with its deeply out valleys and debris-covered stream beds, shows a little more life. Some herbage, shrubs such as juniper, and scattered deciduous trees occur; animals include hares, foxes and ocoasional wolves. Iower down still, camel thorn is typical on the fallow lands, with herbaceous labiate and mimosa species; other families, including Compositae, are represented as weeds in the cropped areas, and other again on saline soils. Plantations of pines and mulberries, vinejards and orchards of apples, apricots, pears, pomegranates, etc., are evident round the villages and torms.

In the lowest parts of the basin, vegetation is mainly represented by isolated low-growing shrubs, mostly Mimosae. The characteristic feature of such sub-desert regi ons is the formation of sandy mounds among the shmub roots, the result of wind erosion. Herbaceous deep-rooted mints and Compositee also occur. Most plant species are used primarily for fodder, and where possible, for fuel.

4. Population In the absence of official census figures, the population of Herat Provinoe is considered to be about 1.3 million; Herat oity is said to have a population of about 160,000. About $65 \%$ of the people are Afghans, while Takiks and Uzbeks predominate among the other races. The majority of the people are muslimsunnites. Agrioulture and animal husbandry are the main occupations, only about $10 \%$ of the working population being employed in commerce, construction or other industries.

As elsewhere in Afghanistan, the distribution of the population is very uneven; the mountainous regions which occupy over $70 \%$ of the region are unpopulated except for nomadic herdsmen. The greater part of the population is therefore concentrated in the valleys of the Hari Hud and other rivers, where natural conditions permit irrigated agriculture, and where agricultural development oan take place as further irrigation facilities become available.

5. Roads and Communications Herat itself, in the heart of the area scheduled for irrigation development, is linked with the oircular highway which is the prinoipal trunkroad of the country, and is also one terminal of the east-west road that passes right through the country to link Pakistan with Iran. This second road traverses the Hari Rud basin and if improved to take heary traffic and made open for heavy traffic, it could serve as the main route for all materials required in irrigation development and dem construotion. At present, however, it is alosed in winter and unmotorable for much of the springe Branch access roads would noed to be constructed to the dam sites. 
Dirt tracks conneot the torms and villages with the main roads; though often steep and narrow, with makeshift bridges, they are motorable for much of the year. Herat has its own fleet of buses and lorries, the latter mainly used for transporting goods entering the countiry from the Soviet Union and Iran. Provinoial passenger and goods transport inoreases anmally. Present oil storage in Herat comprises a reservoir of $800 \mathrm{~m}_{3}$ there are several filling stations. However, muah of the loosl transport is still and is likely to remain, by pack animals.

Herat has en airport, recently reconstructed, with comection by Ariana Afgen Airlines with Kandahar, Kabul, Maimana, Mazar-i-Sherif and Kandus. There is a soattered provincial postal system. Iine telephone and telegraph system Iun through Herat to connect Kabul with Iran, passing through the centre of the basin, but within the provinoe and in Herat itself, telo-commanications are very limited, with batterypowered exahanges. There is radio-telegraphic oommuniostion, however, with Kabal and with other provinoial capitals. 
GHAPUER 6 - SOILS AND PRESENT ILAND USE

1. Ceneral Information Soil surveys in the Hari Rud valley were restrioted mainly to the Herat and Churian valleys, respectively east and west of Herat city, which form the principal cultivated areas of the Herat Province. These valley lands consist mainly of terrace deposits of mired talus-alluvial-loess origins. Some areas have a thick cover formed by long-practised irrigation. The irrigated soils can be classed as brown soils, and the unoultivated desert soils as sierozens. Here also may be included the badly drained saline soils which form a significant part of the areas surveyed. One feature is characteristic of the whole area; this is the absenoe of impermeable horizons or cement sub-soil strata. The soils are friable when moistened. The top horizon has a rather brown tint, which at greater depths becomes darker. The loose surface soil is mixed with sand and fine gravel, blown by wind. It is believed that the surface deposists are underlain by limestones and Flysoh, with tertiary clays and conglomerates.

Outside the cultivated lands in the valley, on both sides of the river, are rocky slopes of infertile debris washed down from the hills. The soil survey in the Hari lud oovered a total of $410,770 \mathrm{ha}$. It comprised, mainly, the Herat valley extending from the village of Obeh, 90 air $\mathrm{Km}$. upstream from Herat, to the distriot centre of Churian, 65 air $\mathrm{Km}$. downstream, as well as the valley soils up to $20 \mathrm{Km}$. east of Obeh and $30 \mathrm{Km}$. west of Churian.

2. Iand Resources of the Basin Table 9 gives data on the land classification for the survejed areas of the Hari Fud valley. The classification follows that defined in Chapter 4 , paragraph 3.

TABLE 9

HARI RUD - ILAND SUITABILITY CTASSIFICATION OF ARFAS SURVFYFD

\begin{tabular}{lrcc} 
Class & I & NII & \\
Class II & 75,730 & ha. \\
Class III & 63,700 & ha. \\
Class IV & 84,930 & ha. \\
Class V & 50,760 & ha. \\
Class VI & 125,650 & ha. \\
\hline & & 410,770 & ha.
\end{tabular}

3. Use of Land Under Present Conditions The agricultural population is dense in the valley around Herat; because of its protected situation, this valley has since ancient times attracted a settled agricultural population which have created here a specialised culture.

Availability of water, gentle topography, ease of drainage, relatively deep and easily-tillable soils have contributed to the development of intensive farming. 
The dryness of the air in the valley, situated at the edge of the desert at an average altitude of $1000 \mathrm{~m} \cdot$, is moderated by the artificial irrigation and the local winds which blow from $N_{0} N_{0} E_{0}$ for 120 days at a stretah, in the season from May to September, coming from Central Asia over the Paropamisus range.

The cultivated lands are primarily owned by big landholders who, as a rule, do not work the land themselves, but rent it out to peasants.

Holdings of petty owners are extremely small (0.3 to $1.0 \mathrm{ha}$ ). Though free lands are available, fit for irrigated agriculture, water shortage under present conditions prevents them from being put under cultivation. Therefore, while practicing the crop-fallow system of irrigation, the peasants are simultaneously engaged in intensive farming on the plots adjoining the villages. In fact, the fields look relatively presentable, the plots being divided into small checks some of which are fenced-in with low mud walls. Up to 100 varieties of plants are cultivated in the Herat valley; sometimes patches of vegetables are grown in the fields, in rotation with field orops; field crops include wheat, barley, millet, maize, pulses ranging from horse beans to lubia; oil bearing plants, though sometimes only in amall patches; sesame, flax, roaket-salad, upland-cress, castor-beans; cotton, alfalfa, Persien clover, Greek clover, hemp, tobacco, melons; figs, pomegranates, peaches, apricots, apples, pears, plums, mulberry.

As wooden stakes are scarce, mud walls are used to support the grape-vines.

Vegetable gardens are usually close to the village and enclosed by mud walls. Here also is a wide variety of plants: apart from the popular eggplants, fall radishes, turnips, onions, garlic, carrots, spinach, cucumbers, tarra, pumpkins, Iuffa, one can see a range of spices and medicinal plants such as dill, coriander, mint, "azhgon", cumin.

There is no generally adopted crop rotation, and wheat, barley, rocket-salad and chick pea are distributed comparatively freely. As a rule, however, pulses are grown after grains. Cotton and rice are usually sown after Persian clover, but never after barley.

On the intensively cultivated lands, the autumn-sown arops includes wheat, barley, alfalfa, Persian clover, rocket-salad (Emuca sativa), Vicia fava. In the spring or early summer are planted peas, lubia, chick pea, cotton, rice, melons, hemp, maize, gourds, tobacco, vegetables (carrots, roots, etc.); the summer sowing lasts till July. Millet, "mash", and often even tobacco, are sown in July after wheat and barley are harvested. Cotton comes next, and the only exception is made for rice: it is sown as a first crop in April. Alfalfa is grown for many years in succession.

The proportions of crops according to their share in the acreage sown is approximately as follows: 1) wheat, 2) barley, 3) alfalfa, 4) cotton, 5) rice, and 6) melons (largely Cucumis melo). Of relatively secondary importance are: rocketsalad, lentils, peas, chick peas, millet and other varieties.

Mineral fertilizer is practically not used in the valley, but earth and organic manures are widely applied every year on the extensively cultivated lands and mainly for summer crops. In the Herat streets, as well as in the villages, women and children can be seen diligently collecting cattle manure. All the Herat Province abounds in pigeon-houses, towering structures which can be mistaken from a distance for mosques. There are hundreds of them in the Herat valley alone, where they form a distinguishing architectural feature; they are not built for the sake of breeding 
pigeons, but just for the production of pigeon dung, which is highly valued as a very effective natural fertilizer. The earth left after the demolition of mud structures and walls is also utilised as fertilizer. Fertilizers are applied but once a year, either in spring or in autumn. Wach hectare receives about 25 tons of earth manure with an adition of dung and other fertilizer.

Table 10 gives figures of current land use:

TABLE 10

HARI RUD - BXISTING IAND USE

1. Lands cultivated for irrigated farming

(of which intensively cultivated and irrigated)

157,260 hectares

(54,700 hectares)

2. Seline lands used as pastures

16,240 hectares

3. Desert lands used as pastures

68,000 hectares

4. Foothill and hilly (undulating) lands used as pastures
169,270 hectares

410,770 hectares

Water for irrigation of the lands is drawn mostly from the Hari lud, but also in part from underground waters by "Warezes".

Despite the fact that over 157,000 ha. are intermittently cultivated for irrigation, the area of anmually cultivated and irrigated lands does not exceed 55,000 ha., since annual irrigation involves only the lands that can be provided with irrigation water under the natural regime of the river. The area under summer crops does not exceed $20 \%$ of the total anmally irrigated acreage, the remaining $80-85 \%$ being under winter crops.

On the whole, agriculture is based on the crop-fallow system, which is necessary here, under the existing farming conditions, for regeneration of the fertility of the soils.

Absence of any control of water use has created conditions in wich the original river water is almost fully taken by the irrigation canals of the upper valley, leaving only water already used for the irrigation of the lower valley. Therefore, wherease there remain fallow, on the average, up to $50 \%$ in the upper valley lands, over $75 \%$ of the irrigable lands in the lower valley have to be left fallow. The yields of grain crops in the upper valley are consequently good, whereas in the lower valley they rarely exoeed five to six times the amount of grain sown, due to lack of irrigation water.

The desert areas adjoining the velley lands on the west are used as pastures. During the winter and spring months, many nomads can be seen here with vast herds of animals (sheep, goats, donkejs, camels and horned cattle) making use of the grazing. 
1. Introduction This chapter gives the general hydrological characteristics of the Hari Rud and Kawgan rivers at the potential sites for storage dams: Assarassum, Tagau Gaza, Marwa, Salma, Tangi Azao and Tangi Shah, which are discussed in Chapter 8. Volume III of this Report - Hydrology - gives hydrological particulars for each of these sites, available for the design of hydraulic structures.

2. Initiel Data The following materials have been used for the estimation of the Heri Rud water resources:

(i) Hydrological observations in the Hari Rud basin, made by the Hydrology Group of the Projeot Team, for the period from 1961 to 1963;

(ii) Data on the run-off of the Hari Rud (Tedjen) and Murgab rivers, observed at the Pul-i-Khatum and Takhta-Bazar gauging atations in USSR territorys

(iii) Data on the Iun-off of the Afghan rivers published in the Soviet Union in the work by V.P. Schultz "Experience in Computing the Surface Water Resources of Afghanistan";

(iv) Data supplied by the Helmand Valley Authority for the rivers of Arghandab (1948-1961) and Khash Rud (1954-1959);

(v) Data collected by the German Hydrological Mission in Afghanistan and the expedition of "Sredazgiprovodkhlopok" Tashkent Designing Institute on the sediment discharge of the Kabul, Jilga and Kharwar rivers, as well as data on the silt charge of the Hari Rud collected at the Tagau Gaza and Herat gauging stations, during the flood periods of 1962 and 1963, by the Hydrological Group of this Projeot.

Systematic hydrological observations in the Hari Rud basin within Afghanistan were started at the end of 1961. by the hydrologists of the Project in cooperation with Afghan counterparts. From 1961 till mid-1963, five gauging stations were set up, of which 4 are equipped with automatic level recorders and cableways.

The waters of the Hari Rud, as used for irrigation, are average in their properties - with a low proportion of exchangeable sodium and a conduotivity a little above average. As the irrigated lands have good vertical drainage, the waters of this river are presently used without visible effects in altering the soil conditions. However, if in the future the trend will be towards development of intense irrigated farming on additional areas upstream of the existing irrigation, it will probably become necessary to adopt measures for land reolamation, the nature and extent of which can be decided after further research and design at the next pre-construotion stage of surveys.

3. River Regime The main features of the water regime of the Hari Rud, as of other rivers of Afghanistan, result from the peculiarities of climate and the relief of the area. These peculiarities are: the comparatively low elevation of the catchments; the instability of the snow cover at heights below $2000 \mathrm{~m}$., and the occurrence of preoipitation only during the cold season, it being almost totally lacking during the months of June-September. 
The instability of the snow cover below $2000 \mathrm{~m}$. , as well as the occurrence of preoipitation in the flatland and foothill zones mainly in the shape of rainfall, cause increased runoffs in the middle and lower reaches of the river during the winter, compared with the low water in the summer. In the upper part of the basins, these features do not occur; weter discharges are similar during the winter and summer low-water periods.

Floods usually begin in March, reach thoir peak in April or early in May, and then begin to diminish. In the upper river, almost constant discharges are observed throughout the entire low water period. For instance, from August till Jamary the river discharges at the Tagau Gaza station are about $6-7 \mathrm{~m} / \mathrm{seo}$. Lower down the river, due to water diversion for irrigation, the run-off practically ceases from June-July and begins again only in the second half of December.

4. Normal Anmual Run-off The methods of estimation of the normal anmual run-off for individual metering sections on the Hari fud and its main tributary, the Kawgan, are desoribed in Volume III. In this ohapter only the main figures are given for the various potential sites for dams or diversion works: Assarassum, Tagau Gaza, Marwa, Tangi Azao and Tangi Shah; of these, the first three sites are on the Hari Rud, and the other two on the Kawgan. In addition, data are given of the normal annual run-off at the Pul-i-Khatum station in Turkmenistan over the period from 1931 through 1955.

The run-off values at these sites are given in Table 11.

TABLE 11

HART RUD BASIN - MEAN NORMAL RUN-OFFS

Normal Anmal Runoff

Names of Sites

\begin{tabular}{|c|c|c|c|c|c|}
\hline Assarasum & Tagau Kaza & Marwa & Tangi Azao & Tangi Shah & $\begin{array}{l}\text { Pul-i- } \\
\text { Khatum }\end{array}$ \\
\hline $\begin{array}{r}33.0 \\
1.0\end{array}$ & $\begin{array}{r}45.0 \\
1.4\end{array}$ & $\begin{array}{r}65.0 \\
2.0\end{array}$ & $\begin{array}{l}8.0 \\
0.25\end{array}$ & $\begin{array}{c}15.0 \\
0.47\end{array}$ & $\begin{array}{c}30.9 \\
0.98\end{array}$ \\
\hline
\end{tabular}

The observed run-off at Pul-i-Khatum is only about half of the estimated run-off at Marwa, though the total catchment area at the former point exceeds that at the second by $47,000 \mathrm{Km}^{2}$. The main reason for such a difference is the diversion of water for irrigation.

In the whole valley of the Hari Rud within Afghanistan approximately 55,000 ha. are now irrigated. In addition, the Hari Rud provides irrigation water to areas in Iran and the Soviet Union. It can be assumed that not less than $1.5 \mathrm{Km}$ water is annually diverted for irrigation in Afghanistan, Iran and the USSR down to Pul-iKhatum. Including this consumption for irrigation with the observed run-off at Pul-i-Khatum, the normal anmual natural run-off at this point would be about $2.5 \mathrm{Km}^{3}$ representing a mean anmial discharge of $78 \mathrm{~m} 3 / \mathrm{sec}$. 
Analysis of the hydrological data shows that the catchment areas downstream of Marwa do not provide any significant part of the mun-off of the Hari Rud.

5. Fluctuations of Anmual Bun-0ff In line with common tendencies in the fluctuations of anmal runoff in mountainous regions, it appears that in Afghanistan the magnitudes of variations in the anmal run-off diminish with increases in the mean elevation of the catchment areas.

The data available for the rivers of Afghanistan, and in particular for the rivers Murghab, Farah Pud, and Arghandab situated not far from the Hari Hud, confirm this conclusion. On the basis of data for these rivers plus the formula derived by the Soviet hydrologiat V.I. Schultz, a probability curve has been defined which enables the fluctuations of the anmal run-off for a period of any required duration to be estimated.

The estimated fluctuations of the anmal run-off over a hundred-year period for the five potential dam sites in the Hari Rud basin are as follows:

\section{TABLE 12}

HARI RUD BASIN - USTIMATMD WATHER DISCHARGAS OF DIFHERENT *PROBABILITIES

istimated normal annual discharges in $\mathrm{m}^{3} / \mathrm{sec}$. with \%age probability

$\begin{array}{lcccccccccc}\text { Assarassum } & 60 & 54 & 51 & 46 & 41 & 32 & 26 & 19 & 17 & 14 \\ \text { Tagau Gaza } & 82 & 74 & 69 & 63 & 56 & 44 & 35 & 25 & 23 & 20 \\ \text { Marwa } & 125 & 114 & 106 & 96 & 83 & 62 & 48 & 33 & 29 & 24 \\ \text { Tangi Azao } & 15.9 & 14.0 & 13.1 & 11.7 & 10.2 & 7.7 & 6.0 & 4.0 & 3.6 & 3.0 \\ \text { Tangi Shah } & 30 & 26 & 25 & 22 & 19 & 14 & 11 & 8 & 7 & 6\end{array}$

$$
\text { * Probability - see Glossary }
$$

6. Anmual Distribution of Stream-Flow All the rivers of Afghanistan, inoluding the Hari Rad, are characterized by an irregular distribution of the run-off within the year. This distribution over the months and seasons, in percent. of the anmal run-off, is similar for the various dam sites on the Hari Rud river. An analogous condition is observed on the Kawgan river, but the anmal distribution is different, because during the cold season more precipitation occurs as rainfall in the Kawgan basin than in the Hari Bud. This results in increased discharges on the Kawgan in the autumn-winter months, which raises the proportion of the anmal run-off for these months. In contrast, on the Hari Rud upstream of the potential dam sites, the major portion of the precipitation is snow, which, as it melts, causes a relatively higher and more lasting flood than that of the Kawgan.

The stream-flow distribution in percent. of the anmal run-offs for an average and a low year are given below for the Hari Rud and Kawgan rivers: 
TABLE 13

HARI RUD BASIN - ANNUAL RUN-OFF DISTRIBUTION IN \%

Type of Year

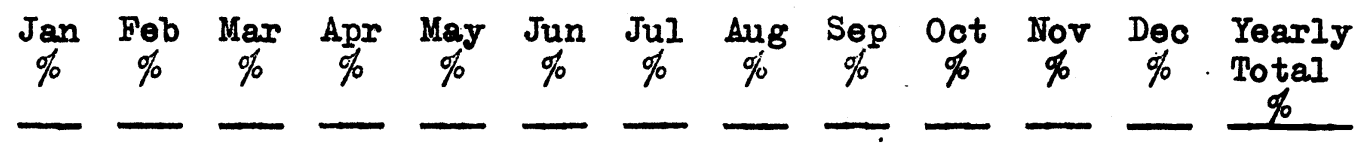

1. Hari Rud

Average year

Low year 1962

$\begin{array}{lllllllllllll}4 & 5 & 14 & 24 & 20 & 10 & 5 & 4 & 3 & 3.5 & 3.5 & 4 & 100 \\ 1.5 & 2.6 & 7.9 & 35.9 & 32.8 & 8.6 & 2.6 & 1.6 & 1.6 & 1.8 & 1.7 & 1.6 & 100\end{array}$

2. Kawgan

Average year

Low year 1962

$\begin{array}{lllllllllllll}6.5 & 7 & 13 & 20 & 18 & 7 & 5 & 4 & 4 & 4.5 & 5 & 6 & 100 \\ 9.4 & 10.9 & 13.1 & 17 & 10.9 & 4.1 & 3 & 3.5 & 4.7 & 6.3 & 8.1 & 8.5 & 100\end{array}$

It can be seen from this table that the following three seasons can be distinguished for all years: spring, summer low-water period, and autumn-winter low-water period.

The following table shows the seasonal distributions of the anmal flows.

TABLE 14

HARI RUD BASIN - STAASONAL RUNOFF DISTRIBUTION IN \%

Type of Year

Hari Pand

Average year

Dry year 1962

Kawgan

Average year

Dry yoar 1962

Spring
(Mar-June)

(Mar-June)

68.0

85.2

58.0

45.1
Summer
(July-Sept)

12.0

7.4

13.0

11.6
Autumn-Winter
(Oot-Feb)

20.0

7.4

29.0

43.3
Yearly

Total

100

100

Remark: To convert the percentage indices to run-off quantities, it is necessary to use for normal years the anmal disaharges given in Table 9, and for dry years the following discharges: Assarassum - $22.6 \mathrm{~m}^{3} / \mathrm{sec}_{\text {. }}$ T Tagau Gaza $-35.8 \mathrm{~m} / \mathrm{sec.8}$ Marwa - $50 \mathrm{~m} 3 /$ sec.; Tangi Azao - $2.5 \mathrm{~m} 3 /$ sec. and Tangi Shah $-6 \mathrm{~m}^{3} / \mathrm{sec}$.

7. Maximum Discharges Maximum discharges of the Hari Hud occur during the flood period, and they differ somewhat in their origin for each of the dam sites.

Snow-melt waters play the most important role in the formation of maximum discharge at all sites. However, in the middle and lower courses of the river maximum discharges may increase because of rainfall occurring at the time snow is melting in the mountains. 
As the snow-melt waters constitute the main component of the maximum discharges, those of the Hari Rud are relatively less than those of the neighbouring river Farah Rud, which derive from storm rainfalls. Therefore the available data for the Farah Rud cannot be used to estimate the maximum discharges of the Hari Rud. Nor is it possible to use for this purpose the observed data for the Hari Rud at Pul-i-Khatum, since these are considerably modified by water abstracted for the irrigation of the upstream lands, by water losses, and by the flattening of the flood wave as it passes over the long stretah from Marwa to Pul-i-Khatum.

To estimate the maximum discharges of the Hari Rud and Kawgan, use was made of the fact that the mean and the maximum discharges of a mumber of Afghan rivers show fairly uniform relationships, especially where the maximum discharges are due to snowmelt. The relationship between the maximum and mean anmal discharges for the Arghandab river over the period of 1948-1961 was ascertained. From this it appears reasonable to assume, for the Hari Rud, that the ratio of maximum to mean anmal discharge will be about 7 or 8 to 1 .

On the basis of this ratio, and the normal anmal mean discharges, there were determined normal anmul maximum discharges for the individual sites for dams or diversion works on the Kawgan and the Hari Rud, as follows:

$$
\begin{array}{r}
250 \mathrm{~m} 3 / \mathrm{sec} \text {. for Assarassum } \\
350 \mathrm{~m} / \mathrm{sec} \text {. for Salma } \\
450 \mathrm{~m} / \mathrm{sec} \text {. for Marwa } \\
60 \mathrm{~m} / \mathrm{sec} \text {. for Tangi Azao } \\
120 \mathrm{~m} / \mathrm{sec} \text {. for Tangi Shah }
\end{array}
$$

From the discharge probability curves and the above discharges, there were estimated maximum discharges of varying probabilities for normal and exceptional

\begin{tabular}{|c|c|c|c|c|c|c|}
\hline $\begin{array}{l}\text { Name of river } \\
\text { and dam site } \\
\end{array}$ & $\begin{array}{l}\text { Conditions } \\
\text { of flow }\end{array}$ & $\frac{\text { Maximum }}{0.1}$ & $\frac{\text { Discharges } \mathrm{m}^{3} / \mathrm{sec} \text {. }}{0.5} \underline{\underline{1}}$ & $\frac{\text { Probability }}{3}$ & $\frac{\text { of }}{5}$ & $\frac{\text { discharge \% }}{10}$ \\
\hline \multicolumn{7}{|l|}{ Hari Rad. } \\
\hline Assarassum & $\begin{array}{l}\text { Normal } \\
\text { Exceptional }\end{array}$ & $\begin{array}{l}820 \\
980\end{array}$ & $\begin{array}{l}630 \\
750\end{array}$ & 530 & 480 & 420 \\
\hline $\begin{array}{l}\text { Tagau Gaza } \\
\text { (Salma) }\end{array}$ & $\begin{array}{l}\text { Normal } \\
\text { Exceptional }\end{array}$ & $\begin{array}{l}1150 \\
1380\end{array}$ & $\begin{array}{r}880 \\
1060\end{array}$ & 740 & 680 & 580 \\
\hline Marwa & $\begin{array}{l}\text { Normal } \\
\text { Exceptional }\end{array}$ & $\begin{array}{l}1470 \\
1750\end{array}$ & $\begin{array}{l}1130 \\
1360\end{array}$ & 960 & 870 & 750 \\
\hline \multicolumn{7}{|l|}{ Kawgan } \\
\hline Tangi Az\&o & $\begin{array}{l}\text { Normal } \\
\text { Excoptional }\end{array}$ & $\begin{array}{l}200 \\
240\end{array}$ & $\begin{array}{l}150 \\
180\end{array}$ & 130 & 120 & 100 \\
\hline Tangi Shah & $\begin{array}{l}\text { Normal } \\
\text { Excoptional }\end{array}$ & $\begin{array}{l}390 \\
470\end{array}$ & $\begin{array}{l}300 \\
360\end{array}$ & 260 & 230 & 200 \\
\hline
\end{tabular}
conditions at the proposed dams. These estimated discharges are given in the following table.

\section{TABLE 15}

HARI RUD BASIN - ESTIMATFED MAXIMUM DISCHARGES AT PROPOSED SITES 
Remark: For exceptional conditions, a safety factor has been applied equal to $20 \%$ of the maximum discharges estimated for normal conditions.

8. Minimum Discharges Owing to a lack of sufficient data of measured disoharges on the Hari aud and Kawgan rivers, for this purpose also use was made of the data for the Arghandab.

By analysis of the mean monthly minimum discharges and mean anmal discharges of the Arghandab, the relationship between them was established. It was assumed that the corresponding relationships for the Hari Rud and Kawgan rivers would be similar.

On these assumptions and employing the data for normal anmal discharges, there were estimated the long-term mean minimum monthly discharges, as follows:-

$\begin{array}{lr}\text { For the Assarassum site } & 6.0 \mathrm{~m} / \mathrm{sec} . \\ \text { For the Tagau Gaza (Salma) site } & 9.0 \mathrm{~m} / \mathrm{sec} . \\ \text { For the Marwa site } & 12.0 \mathrm{~m} / \mathrm{sec} . \\ \text { For the Tangi Azao site } & 1.6 \mathrm{~m} / \mathrm{sec} . \\ \text { For the Tangi Shah site } & 3.0 \mathrm{~m} / \mathrm{sec} .\end{array}$

Using these discharges plus the probability curves, there were estimated the mean monthly minimum dischargos with probabilities from 1 to $99 \%$, that is with a 100-year frequency. The estimated discharges are cited in the following table:-

TABLE 16

FARI RUD BASIN - MEAN MONTHLY MINIMUM DISCHARGES AT POTIENTIAI SITES

Dam site

Mean Monthly Minimum Discharges - Discharge Probability in \% m3/sec.

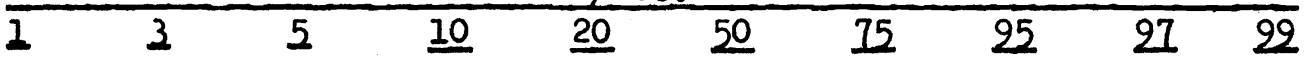

\begin{tabular}{|c|c|c|c|c|c|c|c|c|c|c|}
\hline $\begin{array}{l}\text { Assarassum } \\
\text { Tagau Caza } \\
\text { (Salma) }\end{array}$ & $\begin{array}{l}11 \\
16\end{array}$ & $\begin{array}{r}9.8 \\
14.7\end{array}$ & $\begin{array}{r}9.2 \\
13.9\end{array}$ & $\begin{array}{r}8.4 \\
12.6\end{array}$ & $\begin{array}{r}7.5 \\
11.2\end{array}$ & $\begin{array}{l}5.8 \\
8.7\end{array}$ & $\begin{array}{l}4.7 \\
7.1\end{array}$ & $\begin{array}{l}3.4 \\
5.1\end{array}$ & $\begin{array}{l}3.4 \\
4.7\end{array}$ & $\begin{array}{l}2.6 \\
3.9\end{array}$ \\
\hline $\begin{array}{l}\text { Marwa } \\
\text { Tangi Azao } \\
\text { Tangi Shah }\end{array}$ & $\begin{array}{r}22 \\
3.2 \\
6.5\end{array}$ & $\begin{array}{r}19.7 \\
2.8 \\
5.6\end{array}$ & $\begin{array}{r}18.5 \\
2.6 \\
5.2\end{array}$ & $\begin{array}{r}16.8 \\
2.4 \\
4.6\end{array}$ & $\begin{array}{r}14.9 \\
2.0 \\
3.9\end{array}$ & $\begin{array}{r}11.6 \\
1.5 \\
2.8\end{array}$ & $\begin{array}{l}9.4 \\
1.2 \\
2.1\end{array}$ & $\begin{array}{l}6.6 \\
0.8 \\
1.3\end{array}$ & $\begin{array}{l}6.2 \\
0.7 \\
1.2\end{array}$ & $\begin{array}{l}5.2 \\
0.6 \\
0.9\end{array}$ \\
\hline
\end{tabular}

9. Sediment Discharge The lack of vegetation, the presence of great masses of rock debris, and the considerable slopes of the catchments, result in heavy erosion of the finer fractions of soils by the surface run-off in the basins of all the Afghan rivers. Therefore, during the flood periods, the rivers carry relatively high silt charges, reaching sometimes $8-10 \mathrm{Kg}$. per $\mathrm{m}^{3}$ of water. At the same time, throughout the low-water period, suspended load mun-off is practically non-existent on the rivers of Afghanistan.

Such a conclusion is based on the sediment information collected by the Project on the Hari Rud river at the Tagau Gaza gauging station during 1962-63, as well as on fragmentary data on the fine silt run-off obtained from various sources. These data are given in the following table. 
TABLE 17

MEAN ANNUAL SILT CHARGE OF ARGHANDAB, KABUL AND KHARWAR RIVERS FOR DIFFERENT YEARS

\begin{tabular}{|c|c|c|c|c|}
\hline Name of River & $\begin{array}{l}\text { Looation of } \\
\text { geuging station }\end{array}$ & $\begin{array}{l}\text { Catohment area } \\
\text { in } \mathrm{sq. \textrm {km }} \\
\end{array}$ & Year & $\begin{array}{c}\text { Mean anmual silt } \operatorname{charg\theta } \\
\left(\text { in } \mathrm{Kg} / \mathrm{m}^{3}\right)\end{array}$ \\
\hline Arghandab & $\begin{array}{l}\text { Upstream of } \\
\text { reservoir }\end{array}$ & 15,180 & 1956 & 4.10 \\
\hline $\begin{array}{l}\text { Kabul } \\
\text { Kabul } \\
\text { Kabul } \\
\text { Kharwar }\end{array}$ & $\begin{array}{l}\text { Naghlu } \\
\text { Serobi } \\
\text { Serobi } \\
\text { Upstream of }\end{array}$ & $\begin{array}{l}23,350 \\
25,000 \\
25,000\end{array}$ & $\begin{array}{l}1957 \\
1958 \\
1960\end{array}$ & $\begin{array}{l}1.70 \\
3.70 \\
5.20\end{array}$ \\
\hline & proposed dam site & 592 & 1957 & 2.77. \\
\hline
\end{tabular}

On the observations made at Tagau Gaza and on analysis of the river analogues, the rate of $2.0 \mathrm{Kg} / \mathrm{m}^{3}$ was adopted as the normal anmual silt charge on the Hari lud.

On this rate and the figures of water run-off, there were calculated the normal anmual amounts of suspended load for each potential dam site on the Hari Rud and Kawgan rivers, as follows:-

\section{TABLE 18}

HARI RUD BASIN - SEDIMENT DISCHARGES

\begin{tabular}{|c|c|c|c|c|c|c|}
\hline Dam site & $\begin{array}{l}\text { Suspended } \\
\text { load } \\
\text { (MIn.tons) }\end{array}$ & $\begin{array}{l}\text { Total } \\
\text { Sedim } \\
\text { disch } \\
\text { mln. } \\
\text { tons }\end{array}$ & $\begin{array}{l}\text { ent } \\
\text { arge } \\
\text { mln. } \\
\text { m3 } \\
\text { year }\end{array}$ & $\begin{array}{l}\text { Catchment } \\
\text { area in } \\
\text { sq. km. }\end{array}$ & $\begin{array}{l}\text { Sediment } \\
\text { discharge } \\
\text { per } \mathrm{Km}^{2} \text { of } \\
\text { catchment } \\
\text { (tons) }\end{array}$ & $\begin{array}{l}\text { Proportion } \\
\text { of sediment } \\
\text { discharge to } \\
\text { I sq.km. of } \\
\text { catchment }\end{array}$ \\
\hline $\begin{array}{l}\text { Assarassum } \\
\text { Tagau Gaza } \\
\text { (Salma) }\end{array}$ & $\begin{array}{l}2.1 \\
2.8\end{array}$ & $\begin{array}{l}2.3 \\
3.1\end{array}$ & $\begin{array}{l}1.8 \\
2.4\end{array}$ & $\begin{array}{r}7,430 \\
11,700\end{array}$ & $\begin{array}{l}310 \\
270\end{array}$ & $\begin{array}{l}0.18 \\
0.17\end{array}$ \\
\hline $\begin{array}{l}\text { Marwa } \\
\text { Tangi Azao } \\
\text { Tangi Shah }\end{array}$ & $\begin{array}{l}4.1 \\
0.5 \\
0.95\end{array}$ & $\begin{array}{l}4.5 \\
0.65 \\
1.0\end{array}$ & $\begin{array}{l}3.5 \\
0.44 \\
0.80\end{array}$ & $\begin{array}{r}23,300 \\
2,240 \\
7,200\end{array}$ & $\begin{array}{l}190 \\
250 \\
140\end{array}$ & $\begin{array}{l}0.18 \\
0.18 \\
0.17\end{array}$ \\
\hline
\end{tabular}

Remark: The quantity of bed load in the total sediment discharge is taken as $10 \%$ of the suspended load. 
GHAPTIER 8 - DAMS AND RESERVOIRS

1. General Data on Survered Dam Sites Bight potential storage dam sites in the Hari Hud basin have been considered and examined, 6 on the Hari hud proper and 2 on its tributary the Kawgan. The geologioal charaoteristios of these dam sites are given in Volume II, to which referenoe should be made. Their sites are shown on Draving No. 5.

The topographical and hydrological characteristics of these sites, as well as their distances from Herat and Kabul, are given in the table belowr

\section{TABLT 19}

HARI RUD BASIN - TOPOGRAPHICAI AND HYROLOCI CAI DESCRIPIIOI OF DAM SITES SURVEYR

\begin{tabular}{|c|c|c|c|c|c|c|c|}
\hline $\begin{array}{l}\text { Name of } \\
\text { Reservoir }\end{array}$ & $\begin{array}{l}\text { Maximum } \\
\text { height } \\
\text { (m) }\end{array}$ & $\begin{array}{l}\text { Capacity at } \\
\text { maximum height } \\
\text { (mill.m3) }\end{array}$ & $\begin{array}{l}\text { Normal Anmual } \\
\text { run-off at dam } \\
\text { site (mill.m3) }\end{array}$ & $\begin{array}{l}\text { Dist } \\
\text { in } \mathrm{K} \\
\text { from } \\
\text { Herat }\end{array}$ & noes & $\begin{array}{l}\text { Name } \\
\text { River }\end{array}$ & of \\
\hline $\begin{array}{l}\text { Tasrakay } \\
\text { Assarassum } \\
\text { Pul-i-Sherkhaj } \\
\text { Salna } \\
\text { Tagau Gaza } \\
\text { Tangi Azao } \\
\text { Tangi Shah } \\
\text { Marwa }\end{array}$ & $\begin{array}{r}68 \\
60 \\
\text { J. } 30 \\
60 \\
50 \\
100 \\
116 \\
-\end{array}$ & $\begin{array}{r}474 \\
593 \\
80 \\
220 \\
194 \\
475 \\
267 \\
-\end{array}$ & $\begin{array}{r}850 \\
1,000 \\
1,400 \\
1,400 \\
1,400 \\
250 \\
470 \\
2,000\end{array}$ & $\begin{array}{l}390 \\
350 \\
180 \\
169 \\
153 \\
237 \\
85 \\
67\end{array}$ & $\begin{array}{l}460 \\
510 \\
670 \\
654 \\
670 \\
616 \\
740 \\
756\end{array}$ & $\begin{array}{l}\text { Haxi } \\
" \\
n \\
" \\
" \\
\text { Kawga } \\
\text { Hari }\end{array}$ & $\begin{array}{c}\text { hud } \\
n \\
n \\
n \\
n \\
\text { Pud }\end{array}$ \\
\hline
\end{tabular}

All the above sites were, on tentative examination, considered for the construction of storage dams. It is quite clear that each site will have its merits and its drawbacks. Their final comparative appraisal should be made after the completion of adequate exploration including test drilling, trial pits, and tunneling, preliminary design and estimation of quantities and costs of the engineering work involved, and the appraisal of their importanoe for the development of generel economy in the provinces of the basin. However, preliminary information now available indicates that of these 8 sites three, namely Pul-i-Sherkhaj, TagauGaza, and Marwa, on geologioal grounds alone will not justify further examination as sites for storage dams. Marwa, however, appears to be quite a possible site for a diverwion barrage and canal headworks, as discussed in Chapter 9 below.

2. Suggested Trpes of Dams For each of the 5 remaining sites a tentative seleotion has been made of the most suitable type of dam, based on 4 main considerations, as follows:-

(1) Geological structure of the dam site;

(2) Availability of local building materials;

(3) Minimum use of imported building materials, such as cement, timber, metal;

(4) Accessibility of the dam site from the main highways. 
Accordingly, for purposes of prelindnary appraisal, the following types of dan have been ascumeds

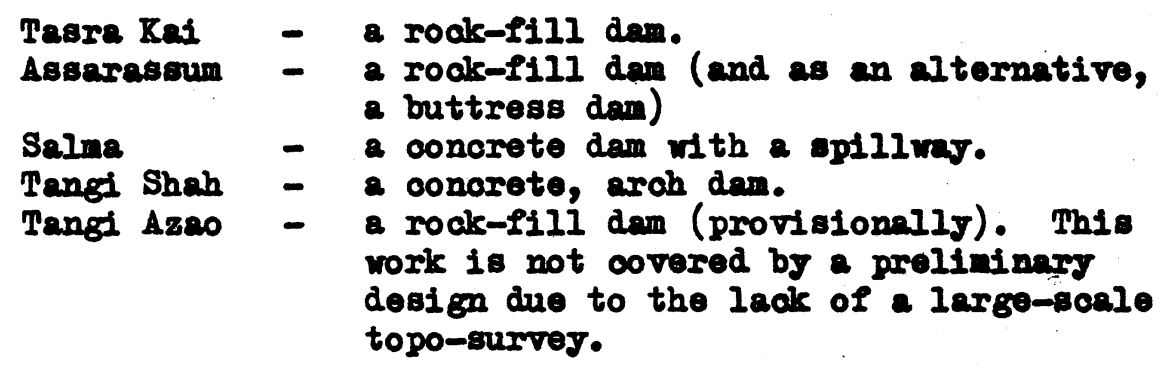

Of these, Tasra Kai at the present stage oan be regarded as an alternative to Assarassum. In the discussion of water control which follows, only the other four reservoirs are assumed to bo available.

3. Saheme of Water Control and Batimated Water Balanoes As discussed in Volume V, to irrigate all the lands of Classes II and III in the Hari lud Valley (149,000 heotares gross area, or 131,000 heotares not irrigable area) at the assumed rates of water requirement totalling $14,250 \mathrm{~m} / \mathrm{h}$ ootares/ year, would require an anmal total of 1866 million m 3 anmally at canal heads. From Chapter 7 above, it is seen that in an average year (50\% probability) the total run-off of the Hari lad at larwa, including that of the Kawgan, is about 2000 million $\mathrm{m}^{3}$. Such a development of irrigation therefore appears to be feasible in an average year provided that sufficient storage capacity can be provided to store the ourpluses and make good the shortages, month by month as they occur. In jears lower then average, 0.8. of $75 \%$ probability, surpluses will be less and shortages will be more; some over-year storage would then be necessary to make good the requirements in full.

Table 20 below provides date for the prospective reservoirs at the four sites mentioned in paragraph 2 above, in respeot of gross capacity, sedinentation to be expeoted in 100 years, and resulting not useful capaolts.

\section{TABLS 20}

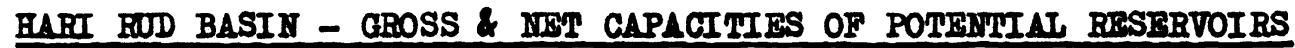

\begin{tabular}{|c|c|c|c|c|c|}
\hline Biver & Reservolr & $\begin{array}{l}\text { Total } \\
\text { Caproity } \\
\text { mills.m }\end{array}$ & $\begin{array}{l}\text { Silted } \\
\text { milear } \\
\text { mils.m } 3\end{array}$ & $\begin{array}{l}\text { lepeoity } \\
100 \text { years } \\
\text { mills.m3 }\end{array}$ & $\begin{array}{l}\text { Not Useful } \\
\text { Capaoity } \\
\text { mills.m } 3\end{array}$ \\
\hline $\begin{array}{l}\text { Hari Pud } \\
\text { Harl Bad } \\
\text { Kawgan } \\
\text { Kawgan }\end{array}$ & $\begin{array}{l}\text { Assarassum } \\
\text { Salma } \\
\text { Tangd Azao } \\
\text { Tangi Shah }\end{array}$ & $\begin{array}{r}593 \\
220 \\
475 \\
267 \\
1555\end{array}$ & $\begin{array}{l}1.8 \\
0.6^{*} \\
0.44 \\
0.56^{*} \\
3.4\end{array}$ & $\begin{array}{l}180 \\
60^{*} \\
44 \\
\frac{56}{340}^{*}\end{array}$ & $\begin{array}{r}413 \\
160 \\
431 \\
211 \\
1215\end{array}$ \\
\hline
\end{tabular}

* Silted Capacity stated as the local silt inflow between this site and the one upstream. 
To assess the possibilities more definitely, computations are given in Volume V of water balances and control, for a net irrigable area of 131,000 hectares, in years of $20 \%, 50 \%$ and $75 \%$ probability, showing surpluses and shortages month by month throughout the year. The results of these are summarised in Table 21 below:-

TABLE 21

BARI RUD BASIN - COMPOTHD WATER BAIANCES \& CONPROL

\begin{tabular}{lccc} 
& \multicolumn{3}{c}{ Probability of Year - Quantities in Millions M3 . } \\
\cline { 2 - 4 } & Ite\% & $50 \%$ & $15 \%$ \\
\hline Run-off & 2617 & 1955 & 1514 \\
Irrigation Requirements & 1866 & 1866 & 1866 \\
Total monthly surpluses & 1248 & 726 & 409 \\
Total monthly shortages & 497 & 637 & 761 \\
Excess of surpluses & 751 & 89 & - \\
Deficit of surpluses & - & - & 352
\end{tabular}

This table shows that while in all years of $50 \%$ probability and better it should just be possible to make good shortages out of previous surpluses, in a year of $75 \%$ probability 352 million $\mathrm{m} 3$ would be required from capacity fllled in some previous year.

These computations were made on the following basis:-

(i) Monthly surpluses and deficits for each assumed year were calculated assuming that the ultimate requirements for 131,000 hectares were fully met.

(ii) All surpluses were assumed to be retained in storage, and all monthly shortages made good from storage.

(iii) Since the effective capacity of the reservoirs on the Kawgan is greater than that of those on the Hari Rud, it is assumed that surpluses were first stored so far as possible in the Kawgan reservoirs, while monthly shortages were made good in the first place from the Hari Bud reservoirs. The idea was to use the Kawgan reservoirs so far as possible for long-term control.

(iv) Evaporation losses were estimated at the mean monthly contents of each reservoir, from graphs of water loss prepared from hydrological and climatological analysis, as described in Volumes III and V.

(v) Infiltration losses, and leakages through gates, were not taken into account, because water so lost will return to the river and be available for irrigation.

The preliminary scheme of water control, recommended for the Hari fud basin, is more fully described in Volume $V$, which gives more particulars of the results of reservoir operation, month by month, in years of $20 \%$, $50 \%$ and $75 \%$ probability. 
On the analysis of observations on the Tedjen river over 33 years, the probability of $75 \%$ assumed for the computation of the water supply for irrigation purposes, on the condition of long-term control of the Hari Bud run-off can be expeoted to rise to $85 \%$.

4. Hydraulic Installations at Reservoirs Preliminary designs for the four dams contemplated in the discussion of water control show the following features:-

a) Assarassum Dam

The works at Assarassum were considered for two types of dam: rook-fill and buttress.

The first version would include the following elements:

1) Rock-fill dam with a ferro-oonorete laminated facing, $30-50 \mathrm{~cm}$. thick.

2) An emergency spillway with a shaft intake and gates, to pess disoherges up to the meximum of $980 \mathrm{~m} 3 / \mathrm{sec}$. (0.1\% probability under excoptional conditions). The adoption of such a high probability rate was necessitated by the fact that an irrigated area of over 100,000 hectares is located below the dam.

3) A hydropower station supplied through a pressure tunnel. Its capacity would be $26,000 \mathrm{KW}$. in three units of 8,670 Kw. each.

4) A diversion tunnel capable of passing a $480 \mathrm{~m} 3 / \mathrm{sec}$. discharge of $5 \%$ probability, with cofferdans to enclose the works area.

The hydralio works for a buttress ferromooncrete dam would include the same elements as the roak-fill dam. However, as this would be a spillway dam, the shaft intake would be replaced by spillway openings with sector gates. The pressure tunnel is also excluded, as the hydroporer station is situated immodiately below the dam, taking water through it.

A tentative caloulation of the costs of these alternative forms shows an undoubted advantage for the rook-fill dam. This oiroumstance once again stresses the importance of using looal building materials for construotion in remote areas. Therefore, in what follows only the rook-fill dam is assumed.

A reservoir $60 \mathrm{~m}$. high can be formed with a total capaoity of 593 million $\mathrm{m}^{3}$. Dead storage sufficient for silting over 100 years requires 180 million $\mathrm{m}^{3}$, and thus the net useful capacity is 413 million $\mathrm{m}^{3}$.

The Assarassum reservoir is intended to provide seasonal storage of the Hari Rud run-off, and to be emptied every year dorn to the dead storage level.

The preliminary technical designs are shown in the drawings Hos.18 \& 19 attached to this Volume. 
b) Salna Dom

Adam $60 \mathrm{~m}$. high will form a rescrvoir with a total oapacity of 220 million $\mathrm{m}^{3}$. Alloving for doad storage for silting over 100 jears 60 million $\mathrm{m}^{3}$, the not avaliable onpaoity of the Salma reservoir will be 160 million $m^{3}$. The Salma desien provides for a conarete grevity dam. The hydrailio works include the following elements:

1) A conorete epillway dam. The emergenoy diecherge of $1380 \mathrm{~m} 3 / \mathrm{se0}$. at $0.1 \%$ probability, is passed through three spillway openings, each with a $15 \mathrm{~m}$. span, controlled by seotor gates at a head of $6.05 \mathrm{~m}$.

2) Irrigation outlets for a disohargo of $130 \mathrm{~m} 3 / \mathrm{sec}$. are built in the body of the dam; their three openings, 5.5 by $2.5 \mathrm{~m}$., provided with seotor gates, are loouted in a special gailery.

3) A hydropower station with a capeoity of $24,000 \mathrm{Kw}$, , has three units. The station building adjolns the dom. Three inlets, corresponding to the mumber of generatose, are in the body of the dem.

4) The diversion tunnel is intended to pass a disoherge of $680 \mathrm{~m} 3 /$ sec. at a $5 \%$ probabilits.

5) The construotion oofferdams to enolose the site of the dam and the power station would be formed of gravels from ralley lands.

Preliminary designs of the Salna works are shown on drating No. 20 attached.

c) Tangt Shah Dam

An arch dem has been designed for this site, $116 \mathrm{~m}$. high, to provide a total reservoir capadty of 267 million $\mathrm{m} 3$. With dead storage of 56 milition 3 , intended for a ailt life of 100 years, the net available capaoity will be 211 million $\mathbf{m}^{3}$.

The Tangl Shah works include the following main elements:

1) An arch dam, domo-shaped.

2) An emergonoy opillway with shaft inteke, to pass a maximum water disoharge of $470 \mathrm{~m} 3 / \mathrm{sec}$, with a $0.1 \%$ probability. The intake shaft joins the diversion tunnol.

3) The diversion tunnel is intended to pass disoharges up to $230 \mathrm{~m} / 800$., with i $5 \%$ probability.

4) The irrigation outlets are built in the dem body. The water discharges from these outlets are controlled with conical valves, which are aheap, sinple to build, and reliable in operation.

5) The construotion cofferdens are made from a mixture of crushed rook and gravel.

6) A dam to olose off the eadde situated on the ridge to the right of the main dam is made of rook-f111, made watertight hy a reinforced conorete feoing.

The preliminary designs of the Tangl Shah works are shown on drawing No.21 atteahed. 
d) Tengi Azeo Dem

The Tangi Azeo dam site was studied only in the office from topographical maps of a 1:50,000 scale. Without a large-scale topo-map it was not possible to prepare a preliminary design of the works.

However, a brief geological reconnaissance was carried out on the spot by the Engineering Geologist, which showed that this is quite acceptable for the construction of a dam.

Sinoe fino-grained materials for the dam core are not to be found in the area, a concrete dam, or a rock-fill dam with a ferro-conorete facing, will be preferable.

The following particulars can be adopted for the water control computations for the Tangi Azao dam and reservoir: maximum height - $100 \mathrm{~m}$; gross reservoir capacity - 475 million $\mathrm{m}^{3}$; dead storage for silting over 100 years - 44 million $\mathrm{m}^{3}$; net available capacity - 431 million $\mathrm{m} 3$. The reservoir is chiefly intended for long-term water control.

5. Quantities of Main Work Items and Costs A table is given below showing the main quantities of work items, as well as the requirements for the main building materials and mechanisms for the construction of the hydraulic works at the Assarassum, Salma and Tangi Shah dam sites, and also their provisional costs.

\section{TABLE 22}

HARI RUD BASIN - QUANTITIES AND COSTS OF POTENTIAL DAMS

No. Desoription

Quentities of Work

1 Excavations of Foundation

2 Rock excavation

3 Tunnelling

4 Rock-fill in Dam

5 Ditto, placed by hand

6 Construction of cofferdams

7 Conoreting of underwater part of power house building and shaft spillway

8 Concrete lining of tunnels

9 Concrete dam facing

10 Gates and operating gear

II Power Plant

12 Clearence of river bed to by-pass water fro hydro power station

13 Concrete in dam
Unit

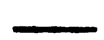

$$
\begin{array}{r}
75.0 \\
11.8 \\
21.4 \\
518.2 \\
34.0 \\
15.0
\end{array}
$$

$"$
$"$
tons
KW

$$
3.4
$$$$
4.3
$$

2.3

560

26,000

Name of Dam

Tangi Azeo

thos.m $^{3}$
23.5
$-\quad 241.5$

$$
\begin{gathered}
- \\
35.0 \\
8.0 \\
- \\
10.0
\end{gathered}
$$

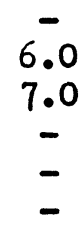

?

?

?

$?$

$?$

$?$

1.6
-
550
24,000

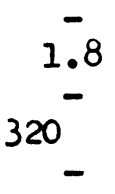

$?$
$?$
$?$
$?$
$?$

? 


\section{TABLE 22 (Cont'd)}

No. Description

\begin{tabular}{l} 
\\
\hline 1 \\
2 \\
3 \\
\\
1 \\
2 \\
3 \\
4 \\
5 \\
6 \\
7 \\
8
\end{tabular}

Building Machinery

1 Excavators, various types

2 Concrete mixing plant

3 Lorries and dump truoks

standard load capacity

4 Bulldozers

5 Motor rollers

6 Concrete pumps

7 Cableway

8 Traction vehicles for narrow gauge

Cost of Hydralic Works
Unit

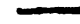

Name of Dam
Asseressum SeIme Tangi Shah

Name of Dam

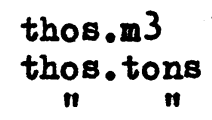

$$
\begin{array}{r}
15.0 \\
2.5 \\
1.5
\end{array}
$$

2.5

20.0
60.0
1.6

10.0
17.0
1.8

?

?

pieces
"
tons

$\begin{array}{rr}5 & 5 \\ 1 & 1 \\ 300 & 300\end{array}$

5
1
200

?

pieces
"
"
"

$\begin{array}{ll}5 & 5 \\ 5 & 3 \\ 2 & - \\ - & -\end{array}$

6

$\overline{6}$

6

3

?

1 Total net cost of hydralic \$ thos.

4893

4052

12190 works

These costs of construction for the hydraulic works at Assarassum, Salma and Tangi Shah are provisionally forecast in accordance with the estimated quantities of work at tentative but reasonable unit rates of cost, as discussed in Volume $V$.

The cost of the works at Tangi Azeo is taken as an average value based on the investment for all the other proposed reservoirs in proportion to the total storage required, $1 . \theta . /(20510 \times 1250)+784 /-20510=\$ 12,190$ thos.

It must be stressed that these figures of cost, based only on reconnaissance data, are subject to considerable modification when more detailed investigations can be made. A margin for contingencies of $15 \%$ or even more would not be unreasonable at this stage.

The total capital investment ( $T a b l e ~ 27$ ) in the whole scheme of works to achieve water control of the Hari Rud basin will reach $\$ 32,700,000$. In this case the specific expenditure for water control per hectare, provided the entire area of 130,900 hectares in the Herat valley is irrigated, will be:

$$
32,700 \div 130.9=\$ 250 \text {. }
$$

This is a comparatively low index of specifio expenditure for water control, and is encouraging in considering irrigation development in the Herat valley. 


\section{CHAPTHR 9 - POTFHTIAI IRRI GATION DEVHLOPIESIT}

1. Land and Water Resources of the Valley The soil survey results indicate that free land resources fit for large-scele irrigation do exist in the basin, mainly in the Herat Valloy.

Acoording to the land classification in the valley, it has been found that Classes II and III lands total 139,430 hectares. These lands need only water, for their condition is such that they would require the minimum of additional reolamation. Reservoirs will however be needed, to develop irrigated agriculture since under present conditions of water use only $40 \%$ of them can be supplied with enough irrigation water.

Classes IV and V lands, occupying a total of over 145,000 heotares, have major limitations, and their agricultural development would call for heavy oapital investment for special reclanation. These lands therefore must be earmarked for a later stage of irrigation development, and only to the extent possible with full control of the water supplies.

In Chapter 7 above the average annual run-offs of the Hari Rud and Kawgan at various points are given as follows:

Hari Rud at Assarassum

Hari Rud at Salma

Kawgan at Tangi Shah

Hari Rud at Marwa

Mills.m ${ }^{3}$
1000
1400
470
2000

Sstimates are 2180 given of the run-offs at probabilities of $20 \%$, $50 \%$ and $75 \%$.

Marwa, downstream of the confluence of the Kawgan, is the mein intake point for the irrigation of the greater part of those lands of the Herat valley which are irrigable without special reclamation. The normal run-off at this point in quantity should suffice for the irrigation of about 140,000 hectares of land, provided the natural water regime is modified through control by reservoirs.

The regime of the Hari Rud, like that of most of the rivers of Afghanistan, is notable for a seasonable run-off distribution which to a considerable degreo limits the expansion of summer crops. inhus, as already mentioned, in the Hari Bud basin the run-off is distributed as follows: Jpring (March-June) - 68\%; Summer (JulySeptember) - 12\%; and Autumn-Ninter (October-F'ebruary) - 20\%. With such a distribution an increase in the sown area of the more valuable summer orops is possible only if the natural regime of the rivers is changed, and this is possible because a considerable portion of the flood run-off at present remains umased.

2. Existing Position of Irrigated Agriculture in the Valley The use of lands in the Herat valley under the present conditions is described in detail in Chapter 6. Here only those problems are discussed which were not covered by that chapter.

The existing irrigated areas with their canal systems that will fit into the projected irrigation scheme, come to 98,000 hectares, out of which 55,000 hectares are anmally sown and irrigated, including 10,000 hectares taken up by homesteads and intensively irrigated orchards and vegetable gardens. 
The irrigation of the present areas is done from more than 80 canals with independent uncontrolled intakes direot from the river.

There are also 137 kareze channels using groundwater, which however irrigate only 608 heotares. The karezes are situated mostly on the right bank of the Hari liud; their depth does not exceed $4 \mathrm{~m}$. , and the inspection shafts are spaced 20-25 m. apart.

The irrigation of the lands is effected usually through "wild" or shoet flooding. The irrigated plots, as a rule, are very well levelled.

Water distribution from the canals, as well as the intake from the river, is chaotio and in no way controlled. During the flood, the canals, having no regulating gates, take in excessive flows which overwater the lands, and may even damage canals and crops.

The peasants have accumulated a very good knowledgo of the natural regime of the irrigation supplies, and select their crops accordingly as desoribed in chapter 6 above.

3. Irrigation Development Scheme The irrigation development saheme for Herat valley provides for the reorganization of the intakes and main canal systems, for the ohange to regular irrigation, and for the elimination of crop-fallow farming.

The irrigation will be normal, by gravity, over an area of 148,800 heotares (gross) or 131,000 hectares (net), mainly Classes II and III lands, with some Classes IV and V lands, commanded by the main canals.

The following reconstruotion scheme is recommended for the valley irrigation system: headworks will be built for the right bank main canal with a discharge capacity of $118 \mathrm{~m} 3 / \mathrm{seo}$, and for the left bank main canal with a discharge of $19 \mathrm{~m} 3 / 800$. The left bank canal, $48 \mathrm{Km}$. long, should ensure water supply to the upper lands on the left bank (16,800 heotares). The main right bank trunk canal, $112 \mathrm{Km}$. long, will feed all the existing right bank canals, with an irrigated area of 67,420 hectares, and also 38,190 hectares on the left bank. Twenty two kilometres upsteam of Herat the main canal has a branch on its left side with a discharge of $22.5 \mathrm{~m} 3 / \mathrm{sec}$. that will cross the Hari Rud through a culvert syphon and join the existing oanal on the left bank to irrigate 21,850 heotares.

Thirty kilometres downstream of Herat an intake is planned from the right bank main canal for another branch to the left with a discharge of $18 \mathrm{~m} 3 / \mathrm{sec}$. This discharge passes into the Hari lad from where the second left bank branch absorbs it for irrigation of 16,340 hectares.

For the irrigation of the lands in the Obeh area, on an area of 8,490 hectares an independent intake will be provided direct from the river.

The developments proposed are shown on drawings $7,10,11,15, \& 16$. Three major drops are anticipated on the main right bank canal: at $\mathrm{Km} .22$ a $70 \mathrm{~m}$. drop; at $\mathrm{Km} .38 .7$, a $39.6 \mathrm{~m}$. drop; and at $\mathrm{Km} .64$, a $39 \mathrm{~m}$. drop. These drops could be used for hydropower stations, as described in Chapter 10 on the hydro power resources of the Hari Rud. 
With the development of irrigation in the valley and the increase in the coefficient of land use, underground water supplies will inorease. As a result, there will be a danger of waterlogging in areas with hampered drainage of surface and ground water. To aroid this, the project recommends the establishment of collector-drainage systems in some parts of the valley. Proper investigations, hydrologioal in the first place, will indicate the best type of drainage, whether by free flow or by lift.

Meanwhile, expert views have been expressed in favour of lift drainage, using the pumped-out water for irrigation. This proposal may prove very effective, as the soanty water resources in the Herat valley put a limit to irrigation development. Since strong winds are prevalent for about 120 days in any jear, it might be possible to use wind power to operate the pumps. There is also the possibility of using eleotric power for lift drainage; it would be practicable to set up a hydro-power - station on the main canal, which would have excess of power during the summer season. Drainage by free flow is also possible and this has been assumed in estimating the costs. The relative advantages and disadvantages of the two types of drainage can be assessed on the basis of technical-economic comparisons, on investigations and preparation of designs.

4. Range of Crops and Irrigation Regime To raise the profitability of agriculture in the Herat valley, the project proposes to increase considerably the area under cash crops, and to raise their productivity, and to develop fodder-fed livestook, pulse and alfalfa crops are proposed.

Table 23 below gives particulars of the existing and proposed ranges of orops at the various stages of reclamation and irrigation development, depending on the extent of water control in the Hari Rud basin.

\section{TABLE 23}

HERAT VALLEY SCHARE - RANGES OF AGRT CULTURAL CROPS

Crop

Areas in thos. ha. and percentages of crops at various stages At present No run-off Run- ff control Full runcontrol but at Tangi Shah off control irrigation system re-

Wheat
Barley
Cotton
Alfalfa and Clover
Orchards
Vineyards

Area \%
$\frac{\text { constructed }}{\text { Area } \%}$

Area 2
by 4 reservoirs

$\begin{array}{rrrrrrrr}33.0 & 61.5 & 40.50 & 45.0 & 34.0 & 34.0 & 42.50 & 32.5 \\ 6.0 & 10.9 & 5.76 & 6.4 & 6.0 & 6.0 & 7.85 & 6.0 \\ 1.5 & 2.6 & 4.95 & 5.5 & 24.0 & 24.0 & 51.00 & 39.0 \\ 1.5 & 2.6 & 2.43 & 2.7 & 5.0 & 5.0 & 13.09 & 10.0 \\ 0.6 & 1.1 & 1.17 & 1.3 & 3.0 & 3.0 & 0.66 & 0.5 \\ 1.2 & 2.2 & 1.98 & 2.2 & 5.0 & 5.0 & 1.31 & 1.0\end{array}$


TABLE 23 (Cont'd)

Crop

Areas in thos. he. and percentages of crops at various stages At present No run-off Run-off control Full runcontrol but at Tangi Shah off control irrigation by 4 resersystem re-

\begin{tabular}{|c|c|c|c|c|c|c|c|c|}
\hline & & & 100. & & & & & \\
\hline & Area & $\%$ & Area & $\%$ & Area & $\%$ & Area & $\%$ \\
\hline $\begin{array}{l}\text { Forest belts } \\
\text { Farmstead plots } \\
\text { Maize for grain } \\
\text { Vegetable gardens \& }\end{array}$ & $\begin{array}{l}- \\
2.0 \\
0.9\end{array}$ & $\begin{array}{l}- \\
3.6 \\
1.6\end{array}$ & $\begin{array}{l}0.90 \\
1.80 \\
2.43\end{array}$ & $\begin{array}{l}1.0 \\
2.0 \\
2.7\end{array}$ & $\begin{array}{l}1.0 \\
2.0 \\
3.0\end{array}$ & $\begin{array}{l}1.0 \\
2.0 \\
3.0\end{array}$ & $\begin{array}{l}1.31 \\
2.62 \\
4.19\end{array}$ & $\begin{array}{l}1.0 \\
2.0 \\
3.2\end{array}$ \\
\hline $\begin{array}{l}\text { melon fields } \\
\text { Pulses } \\
\text { Oilseeds } \\
\text { Rice }\end{array}$ & $\begin{array}{l}1.0 \\
0.8 \\
3.0 \\
3.0\end{array}$ & $\begin{array}{l}1.8 \\
1.5 \\
5.3 \\
5.3\end{array}$ & $\begin{array}{r}0.99 \\
2.70 \\
23.85 \\
0.54\end{array}$ & $\begin{array}{r}1.1 \\
3.0 \\
26.5 \\
0.6\end{array}$ & $\begin{array}{r}2.0 \\
3.0 \\
11.0 \\
1.0\end{array}$ & $\begin{array}{r}2.0 \\
3.0 \\
11.0 \\
1.0\end{array}$ & $\begin{array}{l}1.31 \\
4.40 \\
- \\
0.66\end{array}$ & $\begin{array}{l}1.0 \\
3.3 \\
- \\
0.5\end{array}$ \\
\hline Total & 54.7 & $100 \%$ & 90.0 & $100 \%$ & 100.0 & $100 \%$ & 130.9 & $\overline{100 \%}$ \\
\hline Double Crops & & & & & & & & \\
\hline $\begin{array}{l}\text { Oilseeds } \\
\text { Maize for silage }\end{array}$ & - & $\overline{-}$ & $\overline{-}$ & - & $\begin{array}{l}2.7 \\
2.7\end{array}$ & $\begin{array}{l}2.7 \\
2.7\end{array}$ & $\begin{array}{r}22.0 \\
5.6\end{array}$ & $\begin{array}{r}16.8 \\
4.3\end{array}$ \\
\hline Total & - & - & - & - & 5.4 & $5.4 \%$ & 27.6 & $21.1 \%$ \\
\hline $\begin{array}{l}\text { Grand Totals: } \\
\text { thos. hectares }\end{array}$ & 54.7 & & 90.0 & & 105.4 & & 158.5 & \\
\hline
\end{tabular}

In estimating the rates of irrigation requirement (waterings, frequencies and times) of the crops, as far as possible, the conditions of climate and soils, the depths of ground water levels, and the methods and techniques of irrigation were taken into account. Graphs of the irrigation requirements on the adopted regime and the percent distribution of crops, were also prepared separately for each crop. The overall irrigation rate, including pre-sowing waterings, amounted to a net $8,583 \mathrm{~m} 3 / \mathrm{ha}$ for the cropping plan adopted for the development of 131,000 hectares, as shown in Table 24 . 
TABLE 24

HERAT VALLEY SCHEME - IRRIGATION RATES

Name of crop

Wheat and Barley

Cotton

Maize for grain

Alfalfa and clover

Pulses

Rice

Vegetable garden and melon fields

Orchards, vineyards, and forest belts

Total

Second Crops

Maize for silage

Oilseeds

Total

Grand Total

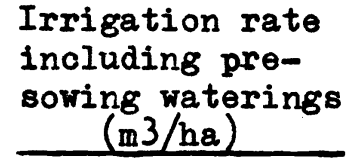
(m3/ha)

$$
\begin{array}{r}
4,300 \\
9,800 \\
6,000 \\
10,300 \\
5,400 \\
20,000
\end{array}
$$

13,000

8,500
Proportion of crops $\%$

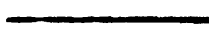

38.5

39.0

.2

10.0

3.3

0.5

1.0

$4 \cdot 5$

$100.0 \%$
Average irriga-

tion rate in

$\mathrm{m} 3$ hectare

$(2 \times 3)$

1,655

3,920

192

1,030

178

100

130

297

$-$

$$
4 \cdot 5
$$

164

3,800

16.8

917

\begin{tabular}{lll}
\hline- & $21.3 \%$ & 1,081 \\
- & $121.3 \%$ & 8,583 \\
\hline
\end{tabular}

The efficiency of the irrigation system is taken as 0.60 . In this case, the gross irrigation rate will be equal to $8,583 \div 0.60=14,300 \mathrm{~m} 3 /$ hectare.

Irrigation Requirements In accordance with the adopted cropping plan and the recommended irrigation rates, Table 25 gives data on the monthly water requirements at the Marwa intake for the development of 131,000 hectares of land.

\section{TABLE 25}

HERAT VALLEY SCHEME - WATER REQUIREMENTS FOR IRRIGATION OF 131,000 HECTARES

Millions of $\mathrm{M}^{3}$

\begin{tabular}{cccccccccccc}
\hline Jan Feb Mar Apr May Jun Jul Aug Sep Oct Nov Dec Annual \\
- & - & - & - & - & - & - & - & - & - & - & -
\end{tabular}

\section{Water require-}

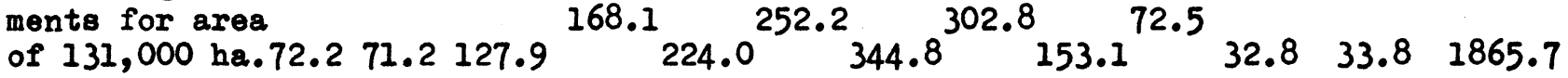

including

second crops

on area of

27,600 ha.

requiring:

$$
-\quad-\quad-\quad-{ }^{(36.7)}(73.7)^{(83.7)}(35.5)^{(3.9)}
$$$$
-\quad-(233.5)
$$ 
These water requirements take into consideration the sowings, after wheat, of maize on an area of 5,600 hectares and of oilseeds on an area of 22,000 hectares.

The computed full water requirements to irrigate 131,000 hectares, 1865.7 million $\mathrm{m}^{3}$, are 134.3 million $\mathrm{m}^{3}$ less than the normal annual run-off of the Hari Rud at Marwa (2000 million $\left.\mathrm{m}^{3}\right)$. Takding into account the losses in the regulating reservoirs, the prospective irrigation requirements are equal to the normal Hari Rud runoff, that is, the irrigating capacity of the river will be completely used. (see Chapter 8 above)

It is necessary to mention that the full development of the land and water resources in the Hari Rud basin will take a long time and will require very large capital investment. It will therefore be necessary to allocate priorities for the measures proposed. As already indicated, the first step would be to regulate the intake and distribution of water to eliminate water losses in the adjoining wastelands and gradually to construot water distributing structures within the irrigation systems. In irrigating additional areas, with a gradual increase of the land use effloiency, it would be necessary to build collector-drains for the lands where conditions of drainage are poor.

Irrigation in the Herat valley will in all probability be developed in three stages. The first will be to an area of about 100,000 hectares, with one storage reservoir. On the balance of conflicting factors, it is recommended that this should be the Tangi Shah reservoir on the Kawgan river, which is nearer than the others to the Herat valley lands, and is cheaper to build. The alternative would be to build first the Assarassum reservoir on the Hari Rud as being larger in capacity, and controlling the larger flows of the main river; this proposal has been put forward. A final conclusion between these alternatives may involve further investigation. In either case the second stage of development will involve the construction of whichever of these two reservoirs has not been built in the first stage, with a corresponding increase in the irrigated area.

The third stage will almost finalise the regulation of the Hari Rud run-off and the development of the irrigation system to 131,000 hectares.

Considering the prospective land-water balance in the basin, it should be noted how close it is, as the irrigation requirements will be equal to the normal annual run-off of the rivers. It will be necessary to find out ways and means of reducing this strain on the balance. However, water balance computations for the irrigation systems of Central Asia have shown that about $20 \%$ of the irrigation water returns to the river. Therefore, under the conditions of the Herat valley, with its irrigated and irrigable lands sloping towards the river, return of a part of the irrigation water into the river can be expected. The extent of this return can be established later, through proper investigations.

Another means of economising irrigation water would be adjustment of the irrigation of second crops. The second orops of maize and oilseeds are sown at the end of May or early in June. By this time the amount of stored water in the reservolrs will be fully known, and in especially low years, when there is not enough water in the reservoirs, the areas sown to the second crops could be reduced. 
6. Quantities of Jain Items of Work and Costs The quantities of the main items of work for the reconstruction and establishment of the Herat valley irrigation system have been derived as specific indices per hectare of the irrigated area, as follows:

1) For main oanal and distributary system:

$\begin{array}{lr}\text { Excavation } & 127.0 \mathrm{~m}^{3} \\ \text { Banking } & 24.0 \mathrm{~m}^{3} \\ \text { Concrete } & 2.32 \mathrm{~m}^{3}\end{array}$

2) For collector-drainage system:

Excavation $\quad 43.0 \mathrm{~m}^{3}$

3) For field irrigation system:

$\begin{array}{lc}\text { Excavation } & 20.0 \mathrm{~m}^{3} \\ \text { Banking } & 18.0 \mathrm{~m}^{3} \\ \text { Concrete } & 0.16 \mathrm{~m}^{3}\end{array}$

4) For field drainage system:

Excaration $\quad 40.0 \mathrm{~m}^{3}$

5) Levelling of fields: $\quad 85.0 \mathrm{~m}^{3}$

6) Road network:

Concrete for road installations and structures

Surfaced roads

Non-surfaced roads

$0.06 \mathrm{~m}^{3}$

6 lin $\mathrm{m}$.

40 lin $\mathrm{m}$.

7) Wind-protective forest belts 7.1 lin $\mathrm{m}$.

Summing up all the speoific quantities, the following results appear:

$\begin{array}{lr}\text { Excavation } & 220.0 \mathrm{~m}^{3} \\ \text { Banking } & 30.6 \mathrm{~m}^{3} \\ \text { Concrete } & 2.40 \mathrm{~m}^{3}\end{array}$

The total of works (without reservoirs) at the various stages of reclamation and development, in relation to the control of run-off, will be as follows: 
TABLE 26

HERAT VALLEY SCHEME - QUANTTTIES OF MAIN WORK ITEMS

Items

Quantities of work in thousand cubic metres

\begin{tabular}{|c|c|c|}
\hline $\begin{array}{l}\text { Full Run-off } \\
\text { control and } \\
\text { irrigation of } \\
130,900 \mathrm{ha} \text {. }\end{array}$ & $\begin{array}{l}\text { Run-off Control } \\
\text { at Assarassum } \\
\text { and irrigation } \\
\text { of } 120,000 \mathrm{ha} \text {. }\end{array}$ & $\begin{array}{l}\text { Run-off control } \\
\text { at Tangi Shah and } \\
\text { irrigation of } \\
100,000 \mathrm{ha} \text {. }\end{array}$ \\
\hline $\begin{array}{r}28,798 \\
4,505 \\
314\end{array}$ & $\begin{array}{r}26,400 \\
3,672 \\
288\end{array}$ & $\begin{array}{r}22,000 \\
3,060 \\
240\end{array}$ \\
\hline
\end{tabular}

$1 \mathrm{~m}^{3}$ of the main work items is estimated to cost:

$\begin{array}{llr}\text { Excavation } & \$ 0.5 \text { per m3 } \\ \text { Earth Banking } & \$ 1.0 \text { per m3 } \\ \text { Concreting } & \$ 100 \text { per m3 }\end{array}$

At these rates the total cost of the irrigation system, including the cost of the reservoir, depending on the extent of the run-off control, will be:

\section{TABLE 27}

HERAT VALLEY SCHEME - COSTS OF IRRIOATION DEVELOPMENT

Description

Cost in Million Dollars

\begin{tabular}{|c|c|c|c|}
\hline $\begin{array}{l}\text { Full run-off } \\
\text { control and } \\
\text { irrigation of } \\
130,900 \text { ha. }\end{array}$ & $\begin{array}{l}\text { Run-off control } \\
\text { only at Assarasum } \\
\text { and irrigation of } \\
120,000 \mathrm{ha} \text {. }\end{array}$ & $\begin{array}{l}\text { Run-off control } \\
\text { only at Tangi } \\
\text { Shah and irriga- } \\
\text { tion of } 100,000 \\
\text { ha. }\end{array}$ & $\begin{array}{l}\text { Run-off } \\
\text { control } \\
\text { only at } \\
\text { Assarassum } \\
\text { and irrig- } \\
\text { ation of } \\
100,000 \text { ha.* }\end{array}$ \\
\hline $\begin{array}{r}14.4 \\
4.5 \\
31.4\end{array}$ & $\begin{array}{r}73.2 \\
3.7 \\
28.8\end{array}$ & $\begin{array}{r}11.0 \\
3.1 \\
24.0\end{array}$ & $\begin{array}{r}11.0 \\
3.1 \\
24.0\end{array}$ \\
\hline 50.3 & 45.7 & 38.1 & 38.1 \\
\hline
\end{tabular}

Total

Items not detailed

\& contingenoies -

$50 \%$

25.2

22.9

4.9

19.0

19.0

Cost of dams

32.7

4.1

4.9

Total

108.2

73.5

61.2

62.0

Specific cost of

irrigation per

hectare (in US \$) 826

612

611

620

* Two versions of the crop composition percentage are given for the Assarassum reservoir. 
The established indices of the speoifio costs of irrigation in the Herat valley leave no doubts as to the ooonomic profitability and future effectiveness of irrigation development in this valley.

Preliminary appraisals of the productiveness of the measures outlined by the design and the prospects of repayment of the capital invested in development of irrigated agrioulture in the Herat valley, are given in Volume VI. 
CHAPTHER 10 - POTHEMIIAL DIEVHLOPYEINT OF HYDROPOWER

1. The hydropower potentials of the proposed reservoirs have been considered for the conditions of their operation to suit the irrigation sohedule when all sultable land resources of the basin (131,000 heotares) are developed for irrigation.

As already mentioned, the reservoirs Assarassum and Salma on the Hari Rud will mainly regulate the seasonal run-off, that is, these reservoirs will be the latest to be filled and the first to be drawn upon.

The Kawgan reservoirs, which have the largest regulating capacities, will be used for everyear regulation of mun-off. Therefore, the Kawgan reservoirs will fill first, and be emptied only after the Harl Rud reservoirs are exhausted.

2. On analysis of the calculations to determine the possible capacities and power outputs of the hydropower stations attached to the Hari Rud reservoirs, as given in Volume V (Dams and Reservoirs), Tables 19, $20 \& 21$, the following should be noted:

(1) The power stations at Assarassum and Salma on the Hari Rud will work continuously throughout the year, producing in March-August about $80 \%$ of their entire annual output, and $20 \%$ during the rest of the year (September-February).

(11) The power stations at Tangi Azso and Tangi Shah on the Kawgan would be 1 dle for part of each year, about 6 months in a high year of $20 \%$ probability, and about 3-5 months in a low year of $75 \%$ probability, on account of the large regulating capacity of these reservoirs, and their operation for overyear storage. In high years the whole flood run-off, surplus to irrigation requirements, will be stored in the reservoir to build up the overyear reserves.

(iii) On the adopted regime for the operation of the Hari Rud stations, it is recommended to use only the potential power resources on the Hari Rud, i.e. only the Assarassum and Salma stations, whose rated capeoity amounts respectively to 26 and $24 \mathrm{MW}$. Construction of the stations at Tangi Azao and Tangi Shah on the Kawgan river would not be economically expedient.

3. Included in the irrigation scheme for the Herat valley, as already mentioned, there are three drops on the right bank main canal; the first of $70 \mathrm{~m}$. at $\mathrm{Km} .22$, the second of $39.6 \mathrm{~m}$. at $\mathrm{Km} .39$, and the third one of $39 \mathrm{~m}$. at $\mathrm{Km} .64$, near Herat. Considering that the right bank canal will always be in flow, it would be justifiable to set up hydropower stations at all these drops. Since these power stations must operate acoording to the irrigation regime of the canal, their power will be usable only for base loads, and the number of hours for the use of the ostablished capacity should not be reoommended to be less than 7000 per annum. 
4. To illustrate this point, a table of possible capacities and power outputs is drawn below, for these power stations when the valley is fully developed to an area of 131,000 heotares.

The data given in Table 28 show that the potential power attainable during the six summer months for all the three stations through the use of the entire run-off considerably excoeds the rated capacity, based on the condition of the annual use of the water - 7,000 hours.

If there is a demand in the Herat valley for seasonal power, then it would be reasonable to increase the capacity of these stations.

5. For the whole Harl Rud basin, including the Assarassum and Salma hydro power stations, as well as the three stations at the drops on the main irrigation canal, the total rated capacity of all stations will be 85.5 thousand $K W$. , and the average multi-annual power output will be 458.79 million KN-hours, as shown in Table 28.

\section{TABLE 28}

MAIN HERAT CANAL - POTENTIAL POWER AND EHNGRCT OUTPUT OF SIALIONS AT DROPS

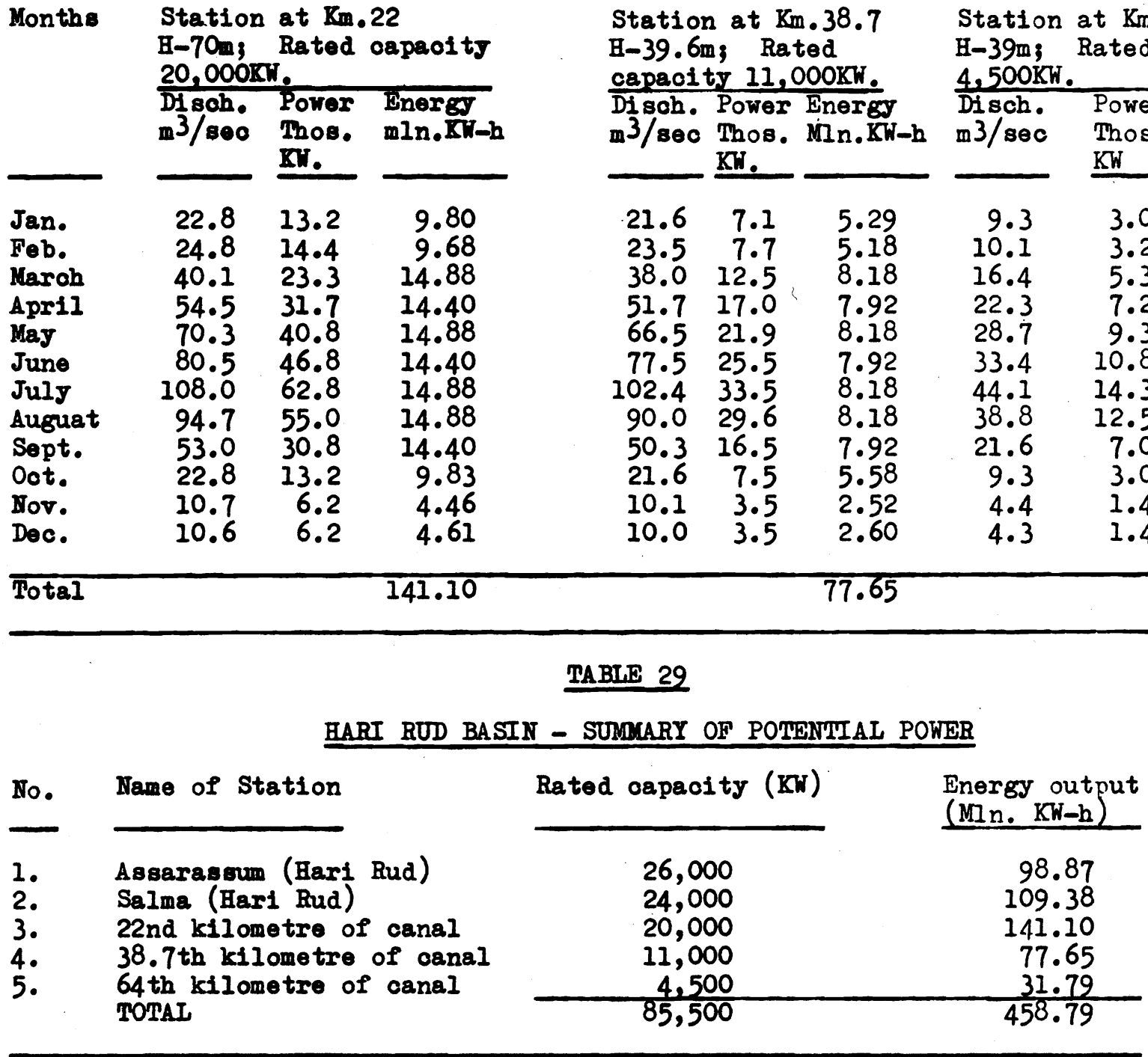


6. Of all the five stations proposed for construotion, the first priority ahould go to the one looated at Kilometre 22 of the main irrigation oanal. This station could be constructed as a temporary sobeme, using water passed down $22 \mathrm{Km}$. of tho main canal, and released to an esoape channel construoted down to the river.

One of the advantages of this atation would be its proximity to the city of Herat, which will initially be the main oonsumer of the power produced. 
CEAPTIER 11 - CONCLUSIONS \& RECOMMEADATIONS

1. On all grounds, considering the umsed resources of land and water available, the further development of irrigation in the Hari Rud basin, and in the first place in the valley of Herat, should be given high priority in the near future, in order to improve the economy and living standards of the Herat Province.

Following the system of land olsssification, it has been established that Classes II and III lands total 139,430 hectares. These are lands that need water only. Their general characteristio is such that they would require the minimum of extra reclamation work. To develop irrigated agrioulture on these lands, the construction of reservoirs is necessary, as under the present conditions of using the Hari Rud waters, only $40 \%$ of these lands are applied with irrigation water.

Classes IV and V lands covering an area of over 145,000 heotares, have large limitations, and development of irrigated agrioulture there will require heary capital investment for special reclamation. These lands, therefore, should be considered for irrigation development only as a distant prospect, and only to the extent possible when run-offs are regulated for irrigation.

2. Under the present conditions, irrigated agrioulture is mainly deroted to growing grains, covering over $80 \%$ of all the areas annually cultivated summer crops take only $20 \%$ of the oropped lands.

The ensuring of supplies of irrigation water to Classes II and III lands, and the introduction of more profitable industrial crops, by increasing summer crops instead of winter orops of lower value, mast be the main tasks in planning the development of irrigated farming in the Herat valley in the near future.

3. The irrigated lands of the valley have a medium texture, with good vertical and horizontal water drainage, and at present are largely free from salinity. Only part of the lands are sown and irrigated intensively. The major portion of the lands fit for irrigated agrioulture are som once every 2-4 years. To shorten the period of time wen the lands mast remain fallow, and to increase the cropped areas, it would be necessary, first of all, to have additional irrigation water.

4. The development of irrigation would necessitates the improvement of the existing irrigation systems the construction of regulating hydraulic structures, and on some lands, also of a collector-drainage networks the putting in order of the water use system; the management of the water resources in the valley, eto.

The establishment of control over the available irrigation waters mat be the first step on the way to normal development of irrigated agrioulture in the valley. Simultaneously with this, the application of mineral and organic fertilizer and the introduction of more correct orop rotation practices and modern agrotechniques, besed on the results of recent research and experiment mast be given priority in the agricultural production.

5. Eren under the existing conditions - lack of irrigation water and waste of a considerable portion of idle fallow lands - in the lower parts of the valley partial salinization and raised underground water levels occur. While at present this oondition exists over a comparatively small portion of the valley, it will spread more videly, particularly with increased intakes of water following the construction of reservoirs, unless there is proper control over water usage. The more water is supplied to the areas situated in the elevated part of the valley, the more frequently 
appear signs of soil salinization and a rise of the ground water levels in the lower parts of the valley. Therefore, to prevent lands falling out of agricultural production, and to maintain their fertility, it would be necessary to create on a part of the lands a collector-drainage network and to regulate the water consumption through establishment of proper control over water use.

6. In the Herat valley, summer crops suffer much from the strong daily winds which prevail in the months of May through August and check their growth. To reduce the harm done by the winds, it is necessary to create special shelter belts by afforestation. These will also help to reduce, and possibly to halt, the windcaused soil erosion, as well. as improving the microclimate in the valley.

7. Land use under the existing conditions in the Hari Rud basin, and the areas fit for irrigation development in the surveyed part of the valley, are given in the following table.

TABLE 30

HARI RUD VALIEY - LAND USE

Total area of surveyed lands in the valley

410,770

Class II-III
lands currently
irrigated
54,700

AREAS IN HECTARES

Irrigable but unused due to lack of water II and III
Class IV-VI lands, non-irrigable and used as pastures

$$
84,730 \quad 271,340
$$

8. The full proposed development of irrigation in the Hari Rud basin is quite possible and necessary, but it is dependent in the first place on the provision of water control. The prospective development of irrigation on an area of 130,900 hectares would require a regulating reservoir capacity of $1250 \mathrm{milli}$ io $\mathrm{m}^{3}$. The proposed reservoirs at Assarassum, Sa lma, Tangi Azao and Tangi Shah have an available total storage of 1215 million $\mathrm{m}^{3}$, almost equal to the requirements.

\section{TABLE 31}

\section{HARI RUD BASIN - SUMMARY OF RESERVOIRS}

\begin{tabular}{|c|c|c|c|c|c|}
\hline $\begin{array}{l}\text { Name of } \\
\text { Reservoir }\end{array}$ & $\begin{array}{l}\text { Net Available } \\
\text { storage } \\
\quad\left(\mathrm{mln} \cdot \mathrm{m}^{3}\right)\end{array}$ & $\begin{array}{l}\text { Run-off at } \\
\text { reservoir } \\
\text { site } \\
\left(\mathrm{mln} \cdot \mathrm{m}^{3}\right)\end{array}$ & $\begin{array}{l}\text { Regulation } \\
\text { coefficient } \\
(2: 3)\end{array}$ & $\begin{array}{l}\text { Capital } \\
\text { cost of } \\
\text { dams } \\
(\$ \mathrm{mln} .)\end{array}$ & $\begin{array}{l}\text { Capital } \\
\text { cost per } \\
\mathrm{m}^{3} \text { of } \\
\text { water of } \\
\text { Available } \\
\text { storage } \\
\text { (cents) }\end{array}$ \\
\hline Assarassum & 413 & $\begin{array}{r}1000 \\
* \quad 400\end{array}$ & $\begin{array}{l}0.41 \\
0.40\end{array}$ & 4,892 & 1.18 \\
\hline Salma & 160 & $\begin{array}{r}1400 \\
* \quad 220 \\
\end{array}$ & $\begin{array}{l}0.11 \\
0.96 \\
\end{array}$ & 11,566 & $7 \cdot 22$ \\
\hline $\begin{array}{l}\text { Tangi Shah } \\
\text { Tangi Azao }\end{array}$ & $\begin{array}{l}211 \\
431\end{array}$ & $\begin{array}{l}470 \\
250\end{array}$ & $\begin{array}{l}\overline{0.45} \\
1.72\end{array}$ & $\begin{array}{r}4,052 \\
12,190\end{array}$ & $\begin{array}{l}1.92 \\
2.83\end{array}$ \\
\hline
\end{tabular}

Note: * Numerator shows run-off with the upper reservoir in existence; denominator shows run-off without the upper reservoir. 
The above data wow that the Assarassum reservoir has the optimum eoonomio index, that is, the lowest oapital investment per $\mathrm{m}^{3}$ of the arailable storage. The regulation coefficient of this reservoir $(0.41)$ is fairly low, indicating that its available capacity will be fully used in all years.

The Tangi Shah reservoir comes seoond, by its good economic inder. This reservoir has the advantage of being closer than the others to the Herat Valley lands proposed for irrigation development.

The Salma reservoir proves to be the most expensive. The capital investment per $\mathrm{m} 3$ of water of the available storage here would be six times that for Assarassum and almost four times that for Tangi Shah.

Shortage of time and fund did not permit completion of the survey and design work for the Tasrakay reservoir on the Hari Bud. It was pointed out in the preliminary design for the Karngen reservoirs that these reservoirs would control a comparatively small run-off. Therefore it would be desirable to examine in further investigation the possibility of inoreasing the oapacity of the reservoirs on the Hari Bud proper. In this case, instead of building the Tangi Azao reservoir on the Kangan river, it might be more advantageous to form a more oapaoious reservoir at Tasrakay on the Hari hud if this proves practioable.

9. The utilization of the water resources in the Hari Rud basin towards irrigation development would require large capital investment and woh time. Therefore, it would be necessary in the future to set up an order of priorities for the construction of the reservoirs, bringing it into relation with the systematio development of irrigation as well as with the general economic development of the valley.

In all probability, the water control in the Hari Rud basin will be started with the construotion of the Tangi Shah reservoir on the Kawgan tributary. This reservoir is the nearest to the Herat valley lands proposed for irrigation development, and the apeoific capital investment per $\mathrm{m}^{3}$ of water from the available storage of the reservoir does not exceed two cents. This particular point, however, deserves further investigation.

10. In Volume VI are given the results of preliminary economic estimations of the relationahip between the value of the production to be expected (a) on first development, and (b) on ultimate operation (20\% higher), and the costs of achieving that produotion. It is there assumed, reasonably, that of the total value of production, $60 \%$ will be absorbed in meeting costs of operation, taxation, etc., leaving $40 \%$ arailable, as profit, to be used for repayment. The capital costs estimated in Chapters 8 and 9 are net, and include no allowances for interest and amortization durins the period of construction and development. If this period is taken as 3 yeare, and interest at $10 \%$ and amortization at $2 \%$ are allowed for, it is estimated that the total gross oosts will be about $26 \%$ more than the net figures. Below are given figures of the resulting comparisons, and of the periods required for repayment, on the basis of both net and gross oapital costs, for the ultimate development of 130,900 hectares in the Herat Valley.

\begin{tabular}{|c|c|c|c|c|c|c|}
\hline $\begin{array}{l}\text { Area } \\
\text { hectares }\end{array}$ & & $\begin{array}{l}\text { Investment } \\
\text { per heotare }\end{array}$ & $\begin{array}{l}\text { Net Profit } \\
\text { of irrigated }\end{array}$ & $\begin{array}{l}\text { er hectare } \\
\text { area }\end{array}$ & $\begin{array}{l}\text { Period after } \\
\text { cost oan be }\end{array}$ & $\begin{array}{l}\text { which oapita } \\
\text { repaid }\end{array}$ \\
\hline & & & $\begin{array}{l}\text { On first } \\
\text { development } \\
\$\end{array}$ & $\begin{array}{c}\text { On ultimate } \\
\text { development } \\
\$\end{array}$ & $\begin{array}{l}\text { On first } \\
\text { development }\end{array}$ & $\begin{array}{l}\text { On ultimate } \\
\text { development }\end{array}$ \\
\hline 130,900 & $\begin{array}{l}\text { Net } \\
\text { Gross }\end{array}$ & $\begin{array}{r}826 \\
1044\end{array}$ & $\begin{array}{l}92.4 \\
92.4\end{array}$ & $\begin{array}{l}142.4 \\
142.4\end{array}$ & $\begin{array}{r}9.0 \\
11.3\end{array}$ & $\begin{array}{l}5.8 \\
7.4\end{array}$ \\
\hline
\end{tabular}

These tentative figures indicate that development in the Herat Valley will be economically profitable. But the measures proposed mast be re-examined in detail before final decisions are taken. 
11. The proposed development of water control at dams and on irrigation canals will provide the following potential amounts of hydro-electric power in the Hari Rud basin:

$\begin{array}{ll}\text { Station } & \text { Installed } \\ \text { Capacity }\end{array}$
Estimated Output
per year
Million KWH

\begin{tabular}{ccc}
\hline Assara ssum & 26,000 & 98.9 \\
Salma & 24,000 & 109.4 \\
Canal - Km.22.0 & 20,000 & 141.1 \\
$"-\mathrm{Km} \cdot 38.7$ & 11,000 & 77.6 \\
$"-\mathrm{Km} \cdot 64.0$ & $\underline{4,500}$ & 31.8 \\
& $\underline{85,500}$ & $\underline{458.8}$ \\
\hline
\end{tabular}

As and when developments for irrigation make these stations possible, it appears likely that their construction and equipment will be economically advantageous, provided that in all cases the appropriate demand can be foreseen. This will require special and careful investigation.

In any case, in the design of the works for water control and irrigation, provision should be included for hydro-power, even if it is not installed when the works are first built. 
SECTION III - FARAH RUD BASIN

CHAPTER 12 - DESCRIPTION OF BASIN

1. General Data. The Farah Rud rises in the western slopes of the Siyah-Koh and flows into the Hamun-i-Sabari lake situated in the Seistan depression, in the southwest part of Afghanistan, near the Iran border. It is $560 \mathrm{~km}$. long. The catchment area totals about $30,000 \mathrm{~km}^{2}$.

The watershed of the basin down to the town of Farah is generally at elevations from $3,200 \mathrm{~m}$. down to $1,800 \mathrm{~m}$. Downstream from Farah the river crosses a plain where the watershed is much less pronounced. The river sources are located at a height of about $3,700 \mathrm{~m}$. and the elevation of the river where it flows into the lake is about $600 \mathrm{~m}$. Thus from source to mouth the river falls about $3,100 \mathrm{~m}$. which gives an average gradient of about $5.5 \mathrm{~m}$. per kilometre. The mountain slopes limiting the river basin are almost devoid of vegetation and deeply cut with stream beds, most of which only flow temporarily. The steep gradients and the lack of vegetative cover contribute at the time of abundant rainfall, to the formation of brief floods whose maximum discharges near Farah town may reach $1,500 \mathrm{~m} / \mathrm{sec}$.

The network of tributaries is considerably better developed in the left-bank part of the basin. The main tributaries of the Farah Rud are: Rud-i-Ghor, Malmand and Zarmardan, with respective catchment areas of $7,220,1,420$ and $2,090 \mathrm{sq} \cdot \mathrm{km}$.

Though the Farah Rud catchment is mainly mountainous, it is rather lower than those of the rivers of northern, and especially eastern Afghanistan. Whereas there is eternal snow in the mountains of eastern Afghanistan, the snow that falls in the Farah Rud basin melts completely by the month of June. In the formation of run-off the main role is played by the catchments lying above $1,500-2,000 \mathrm{~m} \cdot 3$ the se cover $21,000 \mathrm{~km}{ }^{2}$ or about $70 \%$ of all the total catchment area. The run-off from the remaining portion of the catchment. $(9,000 \mathrm{~km} .2)$ is never significant, and is sometimes altogether absent.

The river is widely used for irrigation, and as a result, it almost dries up in the summer season when water consumption for this purpose intensifies near Farah and further downstream.

2. Climate of the Basin. The only meteorological station is at Farah with a three-year series of observations. It has not been possible, therefore, to provide a complete description of the actual climatic conditions throughout the whole basin.

However, to assess the climate, apart from the data supplied by the Farah station, use has been made of data from other stations in Afghanistan, as well as computed characteristics for the proposed dam-sites at Lashkargah, Alikinai and Bakhshabad.

Similarly, the establishment and distribution of meteorological characteristics over the basin were done on the basis of estimations by geographical interpolation.

a) Air Temperatures

As in all mountainous areas, the climate of the lower zones of the Farah Rud differs considerably from that at heights of 1,500-2,000 $\mathrm{m}$. and above. 
The lower zones of the basin, located below Farah town, are amongst the hottest areas in Afghanistan; the mean monthly air temperature of the three summer months (June - August) exceeds $30^{\circ} \mathrm{C}$. The maximum daily air temperature in the daytime during the summer months may exceed $45^{\circ} \mathrm{C}$. In the cold months (December - February) mean monthly air temperatures do not go below $7-10^{\circ} \mathrm{C}$. In the alpine zones (about $3,000 \mathrm{~m}$ ) ) the air temepratures are considerably lower, the cold months having air temperatures below $0^{\circ} \mathrm{C}$. basin.

Table 32 shows computed mean monthly temperatures for various parts of the

TABLE 32

FARAH RUD BASIN - MEAN MONTHLY TERPERATURES

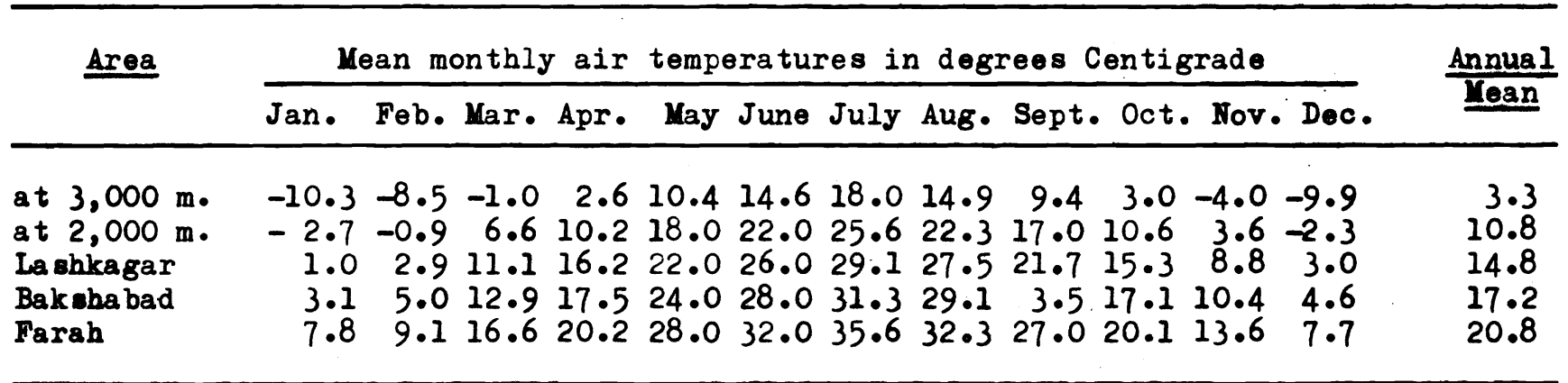

Remarks: 1) The data for Farah are based on observations over three years.

2) For the other areas, computed data are given.

b) Precipitation.

Only insignificant rainfall occurs in the lower parts of the basin throughout the year. Table 33 gives factual data for the Farah meteo-station.

TABLE 33

FARAH RUD BASIN - MEAN YONTHLY PRECIPITATION

Koan monthly precipitation in mm.

Jan. Peb. Mar. Apr. May June July Aug. Sept. Oct. Nov. Dec. Yearly

$\begin{array}{lllllllllllll}26 & 23 & 10 & 1 & 1 & 0 & 0 & 0 & 0 & 0 & 15 & 40 & 116\end{array}$

As in all the other areas of Afghanistan, the precipitation occurs in the cold season and is greater in the mountain areas of the basin. Volume III - Hydrology gives computed precipitation data based on the sketch map of rainfall in Afghanistan and on the Farah Rud run-off, indicating that in the mountain parts of the basin there is about $300 \mathrm{~mm}$. of rainfall annually. 


\section{c) Evaporation}

The above climatic condition cause high rates of evaporation. According to data provided by the Helmand Valley Authority, the annual evaporation for an area situated $70 \mathrm{~km}$. downstream of Farah is $2,920 \mathrm{~mm}$. However, thi value cannot be used to appraise the water losses from the projected reservoirs of Lashkagar, Alikinai and Bakshabad in areas with different temperature regimes and, therefore, evaporation. For the evaporation in these areas, estimated values were used, that fit well, a analysis has shown, into the factual data collected at Farah. The rates adopted as the basis for preliminary design of these reservoirs, as well as the Farah observed data, are given in Table 34 belows

TABLE 34

FARAH RUD BASIN - MEAN YONTHIY EVAPORATION FROY WATER SURFACE - MU.

Area Jan. Feb. Mar. Apr. May June July Aug. Sept. Oct. Nov. Dec. Yearly

\begin{tabular}{lrrrrrrrrrrrrr}
\hline Lashkagar & 80 & 90 & 140 & 170 & 200 & 260 & 280 & 260 & 170 & 140 & 110 & 80 & 1,980 \\
Alikinai & 90 & 100 & 140 & 170 & 210 & 280 & 300 & 260 & 180 & 150 & 120 & 80 & 2,000 \\
Bakshabad & 100 & 110 & 150 & 170 & 220 & 290 & 310 & 260 & 200 & 160 & 120 & 90 & 2,180 \\
Parah City & 110 & 130 & 180 & 210 & 300 & 350 & 460 & 310 & 240 & 180 & 130 & 100 & 2,700 \\
$70 \mathrm{~km}$. below & 70 & 90 & 120 & 290 & 290 & 480 & 520 & 420 & 300 & 220 & 140 & 90 & 2,920
\end{tabular}

Farah

3. Vegetation and Animal life. The physical geography and climate of the Farah Rud basin are the prime causes of its poor vegetation and limited animal life, although intensive grazing may be an ancillary factor in reducing the vegetative cover. In the upper regions of the catchment area, vegetation is very scanty, the rocky materials having very little soil cover, and animal life is little in evidence. Where soil has accumulated in the river gorges, occasional trees and shrubs grow, and more plentiful herbage may be found. Lower down still, a greater variety of species appear, and deciduous trees become more frequent. On the non-irrigated lands in the flatter regions, camel thorn and Mimosa species appear, with further characteristic flora on the saline areas. Shrubs used as fuel occur along the river banks and on the islands where there is also a certain amount of grass cover which forms valuable animal fodder.

4. Population. The Farah Rud basin, covering an area of $30,340 \mathrm{sq} \cdot \mathrm{km} \cdot$, has a very uneven population distribution resulting from the variety of natural conditions. The majority of the population is concentrated in those parts of the basin where suitable conditions for agriculture exist, in contrast to the largely waterless mountain areas.

Administratively, the river basin is located mainly within the Farah Province. Its upper part forms part of the Herat Province. According to unofficial data (no population census has ever been carried out in Afghanistan), the population of the basin is about 300,000. The capital city of the province - Farah - accommodates up to 15,000, and in those parts of the valley surveyed by the Project, the population does not exceed 50,000. The population is mostly Afghan, with some Uzbeks, Tajiks and Turkomans. Agriculture and animal breeding are the principal occupations; only $10 \%$ of the population practise domestic crafts or commerce or are emplnyed in construction work in some fields of the province's rather poor economy. 
5. Roads and Communications. The ofty of Farah is connected, like Herat, with the other regions by a oiroular highway, the principal trunk road in the country. A brief description of this road and the regions which it links is given in Section II, Chapter 5 of this volume. Farah is also connected to Kabul by the much poorer road that crosses the country from east to west.

These roads can be used for the transportation of all material that will be needed in the future for development of irrigation in this area. It should be kept in mind, however, thet in using these roads as trunk routes it would be necessary to construct access roads from these highways to each of the proposed dam-sites on the Farah Rud. Whereas only $30 \mathrm{~km}$. of road would be needed to the Bakshabad site, and its construction would be relatively easy, the road to the Lashkagar site (from the Shindand - Dilaram stretoh of the highway now being constructed with help from the U.S.S.R. would be $100 \mathrm{~km}$. long, and over $50 \%$ of its length would have to be constructed in rockg mountainous country. The majority of the populated centres within the basin are connected with the highway by dirt roads that are not always motorable. These routes abound in steep rises, narrow and ill-levelled road surfaces and makeshift unreliable bridges with limited load capacity.

As in other towns in the country, there is a small motor fleet in Farah that belongs to a joint-stock company. This fleet is used for the transportation of various cargoes beyond as well as within the province. A considerable share of the internal goods traffic however, is still carried by pack animals.

Though Farah is connected by telegraph, radio and telephone with all the large cities in the country, these types of communication are very limited within the province, and at best only telephone lines provide links between Farah and the district centres. 


\section{CHAPTER 13 - SOILS AND EXISTING LAND USE}

1. General Information. The Farah Rud valley extend $\mathrm{s}$ for $40 \mathrm{~km}$. and is divided into two parts by the river. About $2 / 3$ of the currently irrigated lands occupy the right bank, and the rest lie on the left bank. Throughout the length of the valley, the slope is rather gentle (about $1.5 \mathrm{~m}$. per kilometre) falling from $695 \mathrm{~m}$. to $620 \mathrm{~m}$. above sea-level. Starting from the point where the river leaves the mountains, the valley gradually widens and then its width remains constant at about $20 \mathrm{~km}$. over a length of about $20 \mathrm{~km}$. There is no doubt that the Farah valley has been under irrigation for centuries. This is proved by deposits $1.5 \mathrm{~m}$. thick formed as the result of irrigation. Levees along the banks of some of the canals are up to $3-4 \mathrm{~m}$. high and some of them can be compared with the Drian area canals in Iran built 2,500 years ago. Remains of old cities can be traced on the saline as well as on the nonsaline lands.

Small mounds made up of salt concretions can be observed on the saline lands. These testify to the fact that in ancient times the land was made tillable by scraping away the top layer of the soil covered with salt crust, which led to the formation of such mounds.

The upper part of the Farah Rud basin, upstream of Daulatabad, is mountainous and formed by cretaceous limestone, bowl-shaped, with an extensive outcrop of young Farah-Rud volcanic rocks coming out to the surface in combination with sand stone, limestone conglomerates and calc-shales. Ninety kilometres downstrem of Farah there lies the Juwain valley beyond which a desert starts. This valley also includes the Ghankhansur plain partially flooded by the Farah Rud.

In the lower part of the basin, downstream of Dezak, the valley becomes a fanshaped area fringed on both sides by mountains of limestone, limestone schists and sandstone, and volcanic rocks. The Farah valley is based on calc-shales and sandstone covered with pliopleistocene cemented gravels.

Geomorphologically, the Farah Rud valley can be placed together with the desert plains and internal watershed basins of south-western Afghanistan. The valley is divided mainly into the following geomorphological parts:

1) Alluvial fan, somewhat triangle-shaped, where the river enters the valley.

2) The central part, an old valley with top soil one metre thick, the result of centuries-old irrigation.

3) Saline soils formed primarily in depressed areas adjoining the alluvial fan.

2. Description of Soils. The Farah Rud soils were classified as follows:

1) Alluvial soils with a thin (non-irrigation) cover, non-saline and not under irrigation.

2) Alluvial soils with a thick irrigation cover and partial salinity, partly irrigated.

3) Ancient irrigated soils with a thick irrigation deposit on the surface.

4) Saline soils corresponding to solon chaks, with saline-alkaline patches.

5) Gravelly soils. 
The soils of the alluvial fan are medium-textured, 100-105 $\mathrm{cm}$. deep, and have a good structure and good vertical as well as horizontal drainage. They are calcareous, with an average calcium content of $10 \%$ and $\mathrm{pH}=7.5-8.0$. There occur profiles that have no apparent lime or chalk concentration.

In the central valley soils have a noticeable irrigation horizon, $50-100 \mathrm{~cm}$. deep. Calcareous spots are rarely met at depths from 50 to $100 \mathrm{~cm}$. These soils are deeper thar the soils situated in the upper part of the alluvial fan and have individual saline patches.

The ancient irrigated soils are located mainly in the central valley along both banks, and are characterized by a thick irrigation cover with medium drainage. As a rule, these soils are not saline. Ground water is not found above 6 metres deep below the surface. The soils are moderately alkaline with $\mathrm{pH}$ within 7.5 to 8.5 . The salt content is around $7 \%$, and the calcium content is 10-15\%. Solonchak soils with a higher salt content in the upper part (10-15\%) and $\mathrm{pH}=8.0-9.0$ are classified as saline-alkaline soils. There occur in places leached plots under cultivation with salts appearing on the surface. In areas with favourable drainage conditions, cultivated patches can be observed on saline soils. An undulating gravel complex of soils is situated lower down the valley, with individual cultivated plots of thin colluvial soils.

A complete detailed description of the typical soils of the valley is given in Volume IV.

3. Land Resources of the Valley. As the result of the soils surveys and the adopted land classification, information is given below as to the areas of each class of land as described in Chapter 4, paragraph 3.

The area surveyed in the Farah valley was 50,900 hectares. The present periodically cultivated and irricated part of the valley is mainly its alluvial fan, totalling about 25,000 hectares. The rest of the valley is considerably saline and is now cultivated and irrigated in individual patches and mainly used as pastures. All these saline lands used to be under cultivation in ancient times, but lost their fertility due to the poor irrigation system and the unsuitable agricultural practices.

Apart from the lands of the Farah valley proper, the following lands were vi sually surveyed and classified:

1) Near Daulatabad and Dezak (upstream of Farah) on an area of 5,000 hectares Class II lands.

2) Near Juwain ( $90 \mathrm{~km}$. downstream of Farah) on an area of 5,890 hectares; out of these 1,740 hectares are Class II lands, 850 hectares are Class III lands, 1,800 hectares are Class IV lands and 1,500 hectares are Class V lands.

3) Near Kale-i-Ka (40 km. downstream of Farah) on an area of 1,850 hectares; out of these 1,500 hectares are Class II land and 350 Hectares are Class III lands. For reasons explained in Volume I, Chapter II, these are not included in the total area considered to be suitable for regular irrigation, which is therefore taken to be 59,200 acres (see Table 47). 
The preliminary conolusions are that salinization in the Farah valley is the result of the occurrence of a layer of cemented gravels rather close to the surface. The thiokness of the soil parent material varies from 0.5 to $5.0 \mathrm{~m}$. ; in the desert solis it does not exceed $3.0 \mathrm{~m}$. Ihis may be an obstacle to free drainage removal and contributes to a high ground water level.

As the areas of good lands go out of cultivation, the water that remains is used with increasing intensity, which leads to higher groundwater levels and a speedier salinization process. The vicious circle is complete.

Reclamation of Class $\mathrm{V}$ lands is theoretically possible, but it would require a vast amount of work for the establishment of an irrigation and collector-drainage system. Besides, to leach the soil, plenty of water would be needed in the autumn-winter period, whereas there is excess of water only during the spring flood for 3 months in the year. During the rest of the year water is fully utilized upstream and never reaches the Class V lands. Therefore, until the spring run-off is regulated by storage, reclamation of the saline lands is practically impossible.

4. Land Use under Present Conditions. The Farah Rud valley encircling the city of Farah and extending to the north-east for $25 \mathrm{~km}$. and to the south-west for $15 \mathrm{~km}$. from the city, has been long had a settled farming population.

The availability of water, gentle slopes, relative easiness of water derivation for irrigeted purposes, as well as relatively thick and tillable soils, have contributed to development of irrigated agriculture in a part of the valley.

Current practices are indicated in Table 35

\section{TABLE 35 - LAND USE IN FARAH VALLEY}

\section{Type of Land and its Use}

1. Irrigated crop land

2. Farmstead plots, orchards and vegetable gardens, intensively tilled and irrigated

3. Complex of irrigated saline and non-saline lands.

4. Partly irrigated saline soils less intensively cultivated

5. Saline uncultivated and non-irrigated lands, used as pasture

6. Gravelly, eroded saline lands, used as pasture $\frac{\text { Areas in }}{\text { hectares }} \quad \frac{\% \text { of tot- }}{\text { al area }}$

25,100

50

$\begin{array}{ll}2,100 & 4 \\ 3,900 & 7 \\ 2,200 & 4\end{array}$

$15,000 \quad 30$

2,600

Total: $\quad 50,900 \quad 100$


Lands tabled under 2 and 3, over an area of 6,000 hectares, are used, as a rule, for intensive winter and summer cropping with many different crops. However, lands under 1 and 4 , an area of 27,300 heotares, are periodically cultivated and irrigated, with $1 / 3$ of them annually in use and the other $2 / 3$ left fallow to restore the soil fertility. These lands are used primarily for winter crops and mostly for wheat and barley. After these crops are harvested, a portion of the lands (up to $15 \%$ ) is used for secondary crops (corn, cotton, vegetables, etc.)

Item 5 covers 15,000 hectares presently used only as pasture, owing to heavy salinity. However, in the recent past, these lands were cultivated and irrigated, but their hydrogeological conditions called for a collector-drainage network to leach the salt out and to lower and remove ground water. The condition of these lands grew worse with every year, and in time their fertility decreased to the point where their use became economically unprofitable.

The restoration of these lands for crop production is possible provided fundamental reclamation work is done, and first of all the construction of drainage and collector canals. These measures, however, would be justifiable only on the condition that the lands were supplied with enough water for leaching and irrigation.

Irrigated farming is based mainly on the Farah water and partly on the use of groundwater, through the use of karezes.

It is established that 33,300 hectares of periodically cultivated land is available, out of which only about 15,000 hectares are annually cultivated and irrigated. This area can be provided with irrigation water from the river, using its natural regime.

A large variety of field crops is a characteristic feature of the valley's agriculture. However, the principal crop in the valley is wheat, although considerable acreages are occupied by barley,alfalfa, clover and legumes; comparatively small areas are taken for rice and cotton. Vineyards and orchards, vegetable gardens and melon fields are, as a rule, adjoining the villages.

The cultivated lands are worked primarily by their owners, only a very small part being rented out to peasants. The latter have small plots, and there are only few holdings in excess of one hectare. The irrigated areas are broken down into small individual plots and are usually very well levelled.

A strictly applied crop rotation system does not exist, although it is usual to stick to certain crop-rotation practices in sowing individual crops. Wheat and barley are rotated rather freely, but cotton and rice are usually sown after Persian clover, alfalfa and pulses.

Mineral fertilizer is not used; earth fertilizer, with an admixture of manure, is applied annually and on a comparatively large scale, mostly on the individual farmstead plots, where soils are as a rule intensively used. 
CHAPTER 14 - HYDROLOGY

1. Initial Data. In estimating hydrological characteristics for different damsites on the Farah Rud, observed data of the Helmand Valley Authority at the Farah gauging station for the period from 1953 to 1961, were used, plus data for three hydrometric stations set up by the Project's Hydrology team. These data cover a period of observations from one to three incomplete years.

Data for the gauging station at Arghandab on the Arghandab river for the period of 1948-1961 were also used. The Arghandab river was selected as an analogue from the fact that it is subject to conditions of runoff more or less similar to those of the Farah Rud, and has the longest series of observations.

Use was also made of work by Soviet hydrologists published in the USSR. For the sediment discharge of the Farah Rud, materials furnished by the German hydrological team and the Soviet Mission for the Kabul, Julga and Kharwar rivers have been used. points:

The Project's hydrologists set up river gauging stations at the following

1) Pitchi-Tangi station on the Farah Rud at the Bakshabad site - set up at the end of 1960.

2) Malmand station on the Malmand river (left tributary of the Farah Rud) - seven kilometres above the mouth - set up early in 1961.

3) Daulatabad station on the Farah Rud at the bridge, set up in March 1961.

2. Regimes of the Rivers. The main features of the water regime of the Farah Rud are determined primarily by the climatic peculiarities and the relief of the basin (relatively low elevation of the catchment, unsteadiness of the snow cover at heights lower than 2,500-2,000 m., precipitation only during the cold season and none in June to October).

The comparatively low height of the watershed predetermines the early snow melting in the upper parts of the catchment, coinciding with abundant rainfall. It results in a well-pronounced flood wave annually. The flood is of snow-rainfall origin. The run-off during the summer low water period is rather regular, and gradually decreases towards September-October as a result of groundwater depletion. The flood begins in March and reaches its highest levels and discharges in April.

The amplitude of water level variations at the Pitchi-Tangi station in 1961 was about $6 \mathrm{~m}$. and the maximum discharge was over $1,200 \mathrm{~m} / \mathrm{sec}$. During the summer low water period, water discharges here reach $10-15 \mathrm{~m} 3 / \mathrm{sec}$. and in the autumn-winter months $20-30 \mathrm{~m} 3 / \mathrm{sec}$. At the same time at the Farah station, in the low water period water discharges do not exceed 80 litres/sec. All the water from the river upstream of Farah is taken for irrigation, and water flows reach the mouth of the river only during the high water period.

3. Normal Annual Flow. Table 36 gives computed values of the normal annual run-off for the proposed dam-sites on the Farah Rud: Lashkagar, Alikinal and Bakshabad as well as actual mean annual run-off at the Fareh station. 
TABLE 36 - FARAH RUD BASIN - NORMAL ANNUAL RUNOFFS

\section{Runoff Characteristic}

Normal annual discharge m $3 /$ sec.

Normal annual munoff, $\mathrm{km} 3 /$ per annum
Lashkagar

41.0

1.3

1.35

1.40

4. Fluctuations of Annual Run-off. The annual runoffs of the rivers of southwestern Afghanistan, including the Farah Rud, vary from year to year. Thus, on the Arghandab river, over a 14 year observation jeriod, the annual runoff varied within a range from $17.6 \mathrm{~m} 3 / \mathrm{seo}$ (1955) to $87.0 \mathrm{~m} 3 / \mathrm{sec}$. (1957). On the Farah Rud, the annual runoff for the period from 1953 to 1961 varied from 15.4 to $85.7 \mathrm{~m} 3 / \mathrm{sec}$.

In this connection, in designing hydraulic structures, it is important to know how the annual runoff would change over a long period. The fluctuation of the annual runoff over a 100-year period for the various stations on the Farah Bud were computed with the help of probability ourves and Table 37 gives the discharges.

TABLE 37 - FABAH RUD BASIN - COMPUTED MEAN ANNUAL DISCHARGES AT VARYING PROBABILITIES*

Demsite \begin{tabular}{l} 
Computed Mean Annual \\
\hline 3
\end{tabular}

$\begin{array}{lcccccccccc}\text { Lashkagar } & 103 & 87 & 82 & 68 & 56 & 38 & 26 & 14 & 12 & 8 \\ \text { Alikinai } & 109 & 92 & 84 & 73 & 60 & 40 & 27 & 15 & 13 & 9 \\ \text { Bakshabad } & 112 & 94 & 89 & 74 & 62 & 42 & 29 & 15 & 13 & 11 \\ \text { * probability - Seo Glossary } & & & & & & & \end{array}$

In designing hydraulio installations for irrigation purposes, $75 \%$ probability is usually assumed as far as discharges are concerned. With such discharges, the annual runoff at Lashkagar, Alikinai and Bakshabad will be equal to 800,850 and 900 million $\mathrm{m}^{3}$ respectively.

5. Seasonal Runoff Distribution. The Farah Rud, like the majority of Afghan rivers, is characterized by an uneven runoff distribution within the year. The table below shows this distribution in $\%$ of the annual totals for different water years. 
TABLE 38 - FARAH RUD BASIN - MONTHLY RUNCFF DISTRIBUTION IN \%

\begin{tabular}{lllllllllllllll}
\hline $\begin{array}{l}\text { Type of } \\
\text { Year }\end{array}$ Jan. Feb. & Mar. & Apr. & May & June & July & Aug. & Sept & Oct. Nov. & Dec. Yearly \\
\hline $\begin{array}{l}\text { Medium (for } \\
\text { many years }\end{array}$ & 4.9 & 7.6 & 20.4 & 27.7 & 16.0 & 5.8 & 4.6 & 2.2 & 1.7 & 2.0 & 3.1 & 4.0 & 100 \\
High, 1957 & 3.4 & 6.0 & 15.9 & 32.7 & 20.0 & 8.5 & 4.0 & 2.0 & 1.8 & 1.6 & 1.9 & 2.2 & 100 \\
Low, 1962 & 8.0 & 11.4 & 14.5 & 20.2 & 12.8 & 5.4 & 3.7 & 3.4 & 3.6 & 4.2 & 5.0 & 7.8 & 100 \\
\hline
\end{tabular}

TABLi 39 - FARAH RUD BASIN - SEASONAL RUNOFF DISTRIBUTION IN \%

\begin{tabular}{lcccc}
\hline Type of year & Spring & $\frac{\text { Summer }}{\text { Mar-June }}$ & $\frac{\text { Autumn-hinter }}{\text { Jct-Feb }}$ & For Year \\
\hline Medium (for many yrs.) & 69.5 & 8.5 & 21.6 & 100 \\
High Year & 71.0 & 7.8 & 21.2 & 100 \\
Low Year & 52.9 & 10.7 & 36.4 & 100 \\
\hline
\end{tabular}

Note: To convert the percentages to quantities of munoff, it is necessary to use for normal years the annual discharges given in Para. 3 (Table 23) and to use the values of 87.0 and $10.5 \mathrm{~m} / \mathrm{sec}$ respectively for the high and low years.

It is peculiar that in low years the annual runoff $\%$ increases in the autumnwinter months, and is reduced in the flood period.

6. Maximum Discharges. The maximum discharees of the Farah Rud are of rainfall origin therefore they are relatively considerably higher than those of rivers whose maximum discharges are formed by melting snow.

Due to the irregularity of the rainfall in different years, the maximum discharges on the Hari Rud vary much. Thus, at Farah, the maximun discharges during the period 1953-1961 fluctuated from $170 \mathrm{~m} 3 / \mathrm{sec}$. (1958) to $2,210 \mathrm{~m}^{3} / \mathrm{sec}$. (1956). Over this period the mean maximum discharge came to $1,210 \mathrm{~m} / \mathrm{sec}$. Upon analysing all the available materials, the hydrologist of the Project adopted the following normal annual maximum discharges; for the Lashkagar damsite - 1,000 $\mathrm{m}^{3} / \mathrm{sec}$, for Alikinai $-1,200$ $\mathrm{m}^{3} / \mathrm{sec}$. , and for Bakshabad - 1,300 $\mathrm{m}^{3} / \mathrm{sec}$.

Based on these discharges and the probability curve, discharges of various probabilities were computed of various probabilities for normal and exceptional conditions of flow for the proposed storage damsites. 
TABLE 40 - MAXIMUM DISCHARGES OF FARAH RUD OF VARIOUS PROBABILITIES

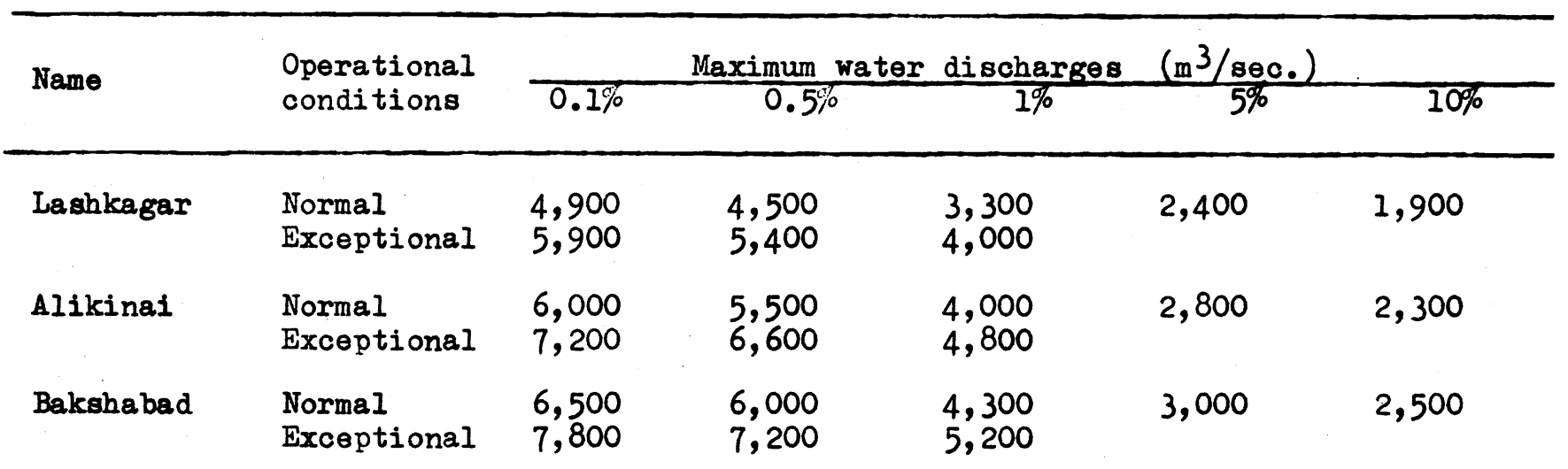

Note: The correction for the exceptional conditions is assumed as $20 \%$ added to the maximum discharges computed for normal conditions.

7. Minimum Discharges. In the low water period in summer when almost all the water is consumed for irrigation, it was not possible to use data of the Farah gauging station to determine the minimum flows. Instead, the data obtained from the Arghandab river were used to determine the minimum runoffs.

Analysis of the mean monthly minimum and the mean annual discharges of this river established a fairly definite relationship between these quantities. Using this relationship and the normal annual discharges, the mean monthly minimum discharges were determined for the damsites as follows:- Lashkagar $-7.8 \mathrm{~m} 3 / \mathrm{sec}$., Alikinai - $8.3 \mathrm{~m} / \mathrm{sec}$. and Bakshabad - $8.35 \mathrm{~m} / \mathrm{sec}$.

Based on these discharges and the probability curves, computations of the mean monthly minimum discharges were carried out with probabilities ranging from 1 - $99 \%$ that is for a 100 year cycle.

TABLE 41 - FARAH RUD BASIN - MEAN MONTHLY MINIMUM DISCHARGES AT VARIOUS PROBABILITIES

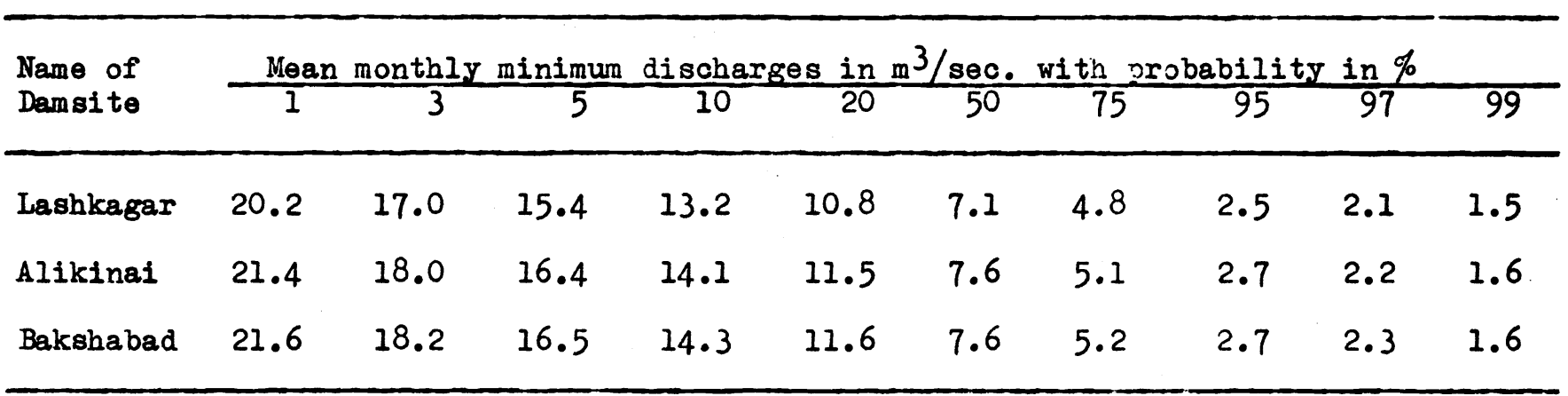

These minimum discharges do not include the water abstracted for existing irrigation of lands situated upstream of the above-mentioned damsites. 
8. Sediment Discharge. During the flood period, a very high silt aharge is observed reaching 8-10 kg. to a $\mathrm{m}^{3}$ of water, but the quantity is negligible during the low water period when the surface runoff on the Farah Rud practically ceases.

Making use of the analysis silt charge data of the rivers of Afghanistan and some neighbouring rivers in Soviet Middle Asia, a normal annual silt charge of 3.0 $\mathrm{kg} / \mathrm{m}^{3}$ was adopted for the Farah Rud. Using this figure and the known water discharge, the normal annual runoff of suspended load for each damsite on the Farah Rud was estimated.

TABLE 42 - FARAH RUD BASIN - SEDIMENT DISCHARGE

\begin{tabular}{llccccc}
$\begin{array}{l}\text { Name of } \\
\text { Darnsite }\end{array}$ & $\begin{array}{l}\text { Suspended } \\
\text { load runoff } \\
\text { (mill. tons } \\
\text { ner year) }\end{array}$ & $\begin{array}{l}\text { Sediment dis- } \\
\text { charge per yr. tons }\end{array}$ & Basin area & $\begin{array}{l}\text { Sediment dis- } \mathrm{m}^{3} \\
\text { charge per } \\
\text { sq. kms. of } \\
\text { catchment (tons) }\end{array}$ & $\begin{array}{l}\text { Ratio of sed- } \\
\text { iment dis- } \\
\text { charge to wat- } \\
\text { er runoff } \%\end{array}$ \\
\hline Lashkagar & 4.0 & 4.4 & 3.4 & 15,300 & 290 & 0.26 \\
Alikinai & 4.1 & 4.6 & 3.5 & 18,300 & 250 & 0.26 \\
Bakshabad & 4.2 & 4.62 & 3.54 & 19,400 & 240 & 0.25 \\
\hline
\end{tabular}

Note: Bed load is taken as 10\% of the suspended load. 


\section{CHAPTER 15 - DAMS AND RESERVOIRS}

1. General Information. The soil surveys show that irrigable land in the Farah Rud basin amounts to 53,200 ha., of which 48,300 are in the Farah valley proper. However, a comparison of the discharge regime of the Farah Rud (Table 40) and the irrigation requirements show that the whole of this area can only be irrigated if run-off is controlled.

Even under the present irrigation conditions, the peak-shaped nature of the Farah Rud runoff, when the water discharges sharply decrease starting from June, puts limits on the economic development of the province, forces cultivators to grow primarily grains, since there is a lack of water for more profitable crops.

Based on the preliminary draft designs and reconnaissance hydro-engineering surveys, three alternative regulating reservoirs are proposed in the mountainous part of the Farah Rud basin.

Their preliminary topographical and hydrological characteristics and distances from the city of Farah are given in Table 43.

TABLE 43 - CHARACTERISTICS OF FARAH RUD RESERVOIRS

\begin{tabular}{lcccc}
\hline $\begin{array}{l}\text { Name of } \\
\text { Reservoir }\end{array}$ & $\begin{array}{c}\text { Maximum Head } \\
(\mathrm{m})\end{array}$ & $\begin{array}{l}\text { Capacity of } \\
\text { Reservoir } \\
\text { (mill. sq. m.) }\end{array}$ & $\begin{array}{c}\text { Normal Annual } \\
\text { Runoff } \\
(\text { cu. km. })\end{array}$ & $\begin{array}{c}\text { Distance from } \\
\text { Farah city } \\
(\mathrm{km} .)\end{array}$ \\
\hline Lashkagar & 91.0 & 566.0 & 1.3 & 168 \\
Alikinai & 67.0 & 540.0 & 1.35 & 116 \\
Bakshabad & 60.0 & 572.7 & 1.4 & 96 \\
\hline
\end{tabular}

It can be seen from the above data that the maximum possible capacity of each reservoir is about the same, but the Lashkagar damsite is the farthest one from Farah and it would be necessary to build an access road, over $100 \mathrm{~km}$. long, through very difficult mountainous country.

The geological-engineering conditions at the reservoir damsites on the Farah Rud are given in Volume II.

2. Water Control Soheme. For an area of 59,200 ha., the total irrigation requirements as at Bakshabad reservoir site will come to 843.6 million $\mathrm{m}^{3}$ whereas the normal annual runoff at the damsite is 1,400 million $\mathrm{m}^{3}$ per annum, and in a year of $75 \%$ probability, 883 million $\mathrm{m}^{3}$. This shows that the planned irrigation can be fully provided with water at $75 \%$ probability (as assumed). 
The comparison of the water supply regime for the irrigation of 59,200 hectares with the natural regime of the Farah Rud shows that in a year with $50 \%$ orobability from May through December, that is, for 6 months, there is surplus runoff of 718.2 million $\mathrm{m}^{3}$, whereas from June through November, also for 6 months, the irrigation requirements exceed the natural runoff of the Farah Rud river, with a deficit of 268.8 million $\mathrm{m}^{3}$. Consequently, seasonal water control is necessary to ensure planned irrigation development in the Farah Rud valley.

At an assumed water supply probability of $75 \%$, the required capacity of seasonal water control is determined by computations of water balances for a year with such probability.

Volume $V$ gives the balance computations as well as the regulation (control) calculations for a year with $75 \%$ probability. The calculations are done for monthly periods.

The total runoff deficit in such a year, for eight months (from June through January) reached 366.3 million $\mathrm{m}^{3}$.

On the basis of the above annual runoff deficit values, in a year with $75 \%$ probability, the available storage of the reservoir is assumed to be 366 million $\mathrm{m}^{3}$.

To illustrate the regime of the reservoirs in high years, Volume $V$ also gives a balance computation for a year with $20 \%$ probability. It should be pointed out that even in a high year the irrigation runoff deficit is observed for a duration of 6 months, from July through December, and reaches 202.6 million $\mathrm{m}^{3}$.

TABLE 44 - FARAH RUD BASIN - BALANCE COMPUTATIONS FOR THREE TYPICAL YEARS

(with 59,200 hectares irrigated)

Balance Elements

Quantities in Millions $\mathrm{m}^{3}$ with probabilities of:

\begin{tabular}{lrrr}
\cline { 3 - 4 } & $20 \%$ & $50 \%$ & $75 \%$ \\
\hline Farah Rud Runoff & $1,923.7$ & $1,293.0$ & 883.0 \\
Irrigation Requirements (59,200 ha) & 843.6 & 843.6 & 843.6 \\
Total surpluses within the year & $1,282.7$ & 718.2 & 405.7 \\
Total deficits within the year & 202.6 & 268.8 & 366.3 \\
Surpluses of annual runoff & $1,080.1$ & 494.4 & 39.4 \\
\hline
\end{tabular}

The above data indicate the availability of free water resources in the Farah Rud basin.

By long-term water control, which can be ensured through construction of several reservoirs, an additional 32,000 hectares could be irrigated (beyond the 59,200 hectares) with the available runoff surpluses in a $50 \%$ probable year (494 million $\mathrm{m} 3$ ), the average irrigation quota beirg $14,250 \mathrm{~m} 3 /$ ver hectare. 
Unused lands are available in the Seistan valley where the surplus Farah Rud flows could be directed. This problem will have to be settled in the future.

The storage required for seasonal control being 366 million $\mathrm{m}^{3}$, and the silt Iife equal to 50 years, the total capacity of the reservoirs, depending on their respective damsite locations, is given in the following table:

TABLE 45 - REQUIRED CAPACITY OF FARAH RUD RESERVOIRS

\begin{tabular}{lccccc}
\hline $\begin{array}{l}\text { Name of } \\
\text { reservoir } \\
\text { damsite }\end{array}$ & $\begin{array}{l}\text { Required } \\
\text { regulating } \\
\text { capacity } \\
\text { (mill. } 3 \text { 3) }\end{array}$ & $\begin{array}{l}\text { Annual } \\
\text { Sediment } \\
\text { runoff } \\
\left.\text { (mill. } \mathrm{m}^{3}\right)\end{array}$ & $\begin{array}{l}\text { Sediment } \\
\text { runoff for } \\
\text { (mill years }\end{array}$ & $\begin{array}{l}\text { Losses from } \\
\text { Reservoirs } \\
\text { (mill. cu.m) }\end{array}$ & $\begin{array}{l}\text { Total } \\
\text { Reservoir } \\
\text { Capacity } \\
\text { Required } \\
\text { (mill. m3) }\end{array}$ \\
\hline Lashkagar & 366 & 3.4 & 170 & 30 & 566 \\
Alikinai & 366 & 3.5 & 175 & 30 & 571 \\
Bakshabad & 366 & 3.54 & 177 & 30 & 573 \\
\hline
\end{tabular}

Because of its topographical conditions, the total canacity of the Alikinai reservoir cannot exceed 540 million $\mathrm{m}$, and its estimated silt life would thus be only 41 years.

The possible regime of the three comparable reservoirs for the three characteristic years is given in Volume $V$, for the condition of irrigation requirements fully met.

The estimations show that in resnect of compliance with the irrigation requirements all the reservoirs are equally valuable. Because of the lower position of the Bakshabad reservoir, its evaooration losses are higher by $47 \%$ as compared with Alikinai reservoir and by $80 \%$ as compared with Lashkagar reservoir.

In respect of power production, the Lashkagar reservoir is the most advantageous as the head is higher though the water discharges are lower. If power generation by the Lashkagar reservoir is taken as 100\% then the Alikinai reservoir power production will be $73 \%$ and that of Bakshabad $66 \%$.

3. Headworks at the Reservoirs. In accordance with the irrigation develonment scheme described in Chapter 16 and the water control calculations given above, further integrated use of the basin's water resources is possible. The structures at potential reservoirs - to bring this about are briefly described below. Hore detailed descriptions are contained in Volume $V$.

a) Bakshabad Installations. Due to the absence of fine-grain materials suitable for the impermeable dam core or facing, a rockfill dam is practicable only with a ferro-concrete facing. However, the occurence in the river bed of a tectonic displacement with a crushed zone would make the junction between the facing, the river bed and the banks complicated. Therefore, at this damsite a concrete gravity dam is recommended. 
The installations include the followings a dam, a hydropower station, a spillway and an irrigation outlet.

It is planned to pass the maximum elood discharge of $4,300 \mathrm{~m} / \mathrm{sec}$. (1\% probability) through four spillway openings, each with a apan of $20 \mathrm{~m}$, and a hoight of $8.8 \mathrm{~m}$. fitted with segment gates.

The present stage of the project does not consider the storage of the flood peak in the reservoir, as well as getting rid of a part of the flood through the power station and the irrigation outlets.

It is anticipated to pass flood peaks of $3,000 \mathrm{~m}^{3} / \mathrm{sec}$. ( $5 \%$ probability) during the construction period through two horseshoe-mbeped tunnels, $437 \mathrm{~m}$. long and $12 \mathrm{~m}$. in diameter. gravel.

The dam foundation will be enclosed by $18.5 \mathrm{~m}$. ooffordams made of sand and

The irrigation outlets and the power station ducts will pass through the dam body and be fitted with gates.

The total estimated disoharge of the irrigation outlets will come to $65 \mathrm{~m}^{3} / \mathrm{sec}$. giving a margin of $50 \%$ over the discharge required according to the water control calculations.

The passing of this discharge should be ensured at the lowest operating level of the reservoir.

For each of the three generators of the power station (total capacity 24,000 Kw.) there is planned the maximum estimated discharge of $19.7 \mathrm{~m}^{3} / \mathrm{sec}$, according to the irrigation schedule. The estimated head is $50 \mathrm{~m}$.

It is anticipated to close the saddle on the left side of the reservoir between the Farah Rud and the Takhta-Taimar dry bed with a dam made of rock and gravel materials.

The draft design of the hydropower installations, and the structure and dimensions of its elements are given in drawing No. 22 attached.

A dam at the Bakshabad site, with a head of afound 60 m. will be able to oreate a reservoir with a total capacity of 572 million $\mathrm{m}^{3}$.

b) Alikinai Installations. Twenty kilometres upstream of the Bakshabad aite it would be possible to construct the Alikinai dam and reservoir. At a beight of $67 \mathrm{~m}$. the reservoir capacity will be 540 million $\mathrm{m}^{3}$.

The Alikinai installations will include:

1) Concrete gravity dam.

2. Irrigation outlet to pass (at the minimum head of $15 \mathrm{~m}$ ) a forced discharge of $54 \mathrm{~m}^{3} / \mathrm{sec}$. The regulating gates will be fitted into a pecial gallery in the body of the dam. From the same gallery the repair gates will also be operated. 
3) Surface emergency spillway consisting of four spillway openings in the orest of the dam each with a span of $20 \mathrm{~m}$ and a height of $8.4 \mathrm{~m}$. , controlled by segment gates. The draft designs are shown in Drawing No. 23.

4) There is a saddle on the right side of the dam, that will be closed with a rockfill gravity dam with a ferro-conorete facing.

5) A hydropower station with a capacity of $26,000 \mathrm{Kw}$. is located to the right of the emergency spillways, and the power house adjoins the dam. The estimated head is $50 \mathrm{~m} \cdot$, the estimated discharge is $62.5 \mathrm{~m} / \mathrm{sec}$. There will be three generators. The water will be fed to the turbines through pipes incorporated in the dam body.

6) The construction discharge will be passed through a tunnel $658 \mathrm{~m}$. long.

c) Lashkagar Installations. By its topographical conditions and location the Lashkagar works differ sharply from the two others. There is a narrow gorge, $29 \mathrm{~m}$. wide at the river level and $148 \mathrm{~m}$. wide at the dam crest level, $90 \mathrm{~m}$. high.

However, the favourable topographical conditions are hampered by the considerable remoteness of the area from the existing highways, as well as from Farah town, the centre of the proposed water use.

To make the construction of hydraulio installations possible at the proposed site, it would be necessary to build a motorable road, $100 \mathrm{~km}$. $10 \mathrm{ng}$, of which at least $50 \%$ would be in extremely diffioult mountainous conditions. Therefore, apart from a considerable expenditure for the construction of the access road, necessary only for the construction, as the local needs are quite adequately met by pack tracks, extra expenditure for transportation of materials from outside will be necessary.

Under such conditions it would be necessary to approach the problem of selecting a proper design for the installations with the utmost care.

Owing to the narrow gorge, it would be obligatory to provide for the passage of river flows through a construction tunnel, irrespective of the type of the dam, whether concrete arch or gravity dam, or a rockfill dam with a ferro-conorete facing (no fine-grain materialo are available for the dam oore or facing.)

The existence of a major river bend on the stretch under review would make it possible to straighten it with a construction tunnel, about $500 \mathrm{~m}$. Iong. (In the oase of Bakshabad and Alikinai, the lengths of the tunnels would be 437 and $658 \mathrm{~m}$. respectively.

Although the topographical conditions are extremely favourable for the construction of a light arch dam, such a possibility remains doubtful because in the construction area there are major tectonic irregularities, and because only limited geological and engineering investigations have so far been possible. Taking all this into consideration, a rockfill dam with a ferro-concrete facing is proposed.

The Lashkagar installations include the following elements: a rockfill dam with a ferro-conorete facing, a diversion tunnel, a horse-shoe shaped emergency spillway leading to the diversion tunnel; the construction of cofferdams and a hydropower station. The dam creates a reservoir with a capacity of 566 million $m$. According to the water control calculations, the silt life of the Lashkagar regervoir is taken as 50 years, for which period the capscity required is 170 million $\mathrm{m}^{3}$, and the balance of available storage is 396 million $\mathrm{m}^{3}$. 
The design of the rookfill dam is given in Drawingllo. 24.The height of the dam is $91 \mathrm{~m}$., the crest width $4 \mathrm{~m}$, the height over the normal reservoir level $2 \mathrm{~m}$., the crest length $147 \mathrm{~m}$., the slopes $1.7 \mathrm{~m}$. and the ferro-concrete faoing is 30 to $90 \mathrm{~cm}$. thick.

The diversion tunnel is horse-shoe shaped, $12 \mathrm{~m}$. in diameter, and is designed to pass a flood peak, of a $5 \%$ probability with a discharge of $2,400 \mathrm{~m} / \mathrm{sec}$. The height of the upstream cofferdam is determined at $20 \mathrm{~m}$. to pass the flood peak. The trenoh-shaped emergency spillway is meant to pass the maximum flood discharge of $3,300 \mathrm{~m}^{3} / \mathrm{sec}$. with a $1.0 \%$ probability. It is controlled by four gates, each $30 \mathrm{~m}$. wide and $5.6 \mathrm{~m}$. in height. At this stage of design it is not considered reasonable to take into account the reduction of flood peaks by the effect of the reservoir, or by flows passing through the power station.

The water from the trench-shaped spillway passes to the diversion tunnel by an inclined shaft. It is intended to use the rook in the body of the rookfill dam.

The hydropower station on the left bank with a capacity of 34,000 Kw. is of a derivation type, to be fed by a pressure tunnel. The rated head of the power house is $76 \mathrm{me}$ and the rated discharge is $55 \mathrm{~m} / \mathrm{sec}$.

The diameter of the derivation tunnel is $4.5 \mathrm{~m}$. Before the slope towards the hydro-power station, a surge chamber of $10 \mathrm{~m}$. diameter is to be built on the derivation tunnel.

At the station it is intended to instal three generators each $11,330 \mathrm{Kw}$. To pass the irrigation discharges, in case of an emergency halt, a passway is provided, housed in a special block. After passing through the station, the water is returned to the river.

4. Quantities of the main work items and costs. A table is given below showing the main items of work and requirements for building materials and equipment for construction of hydraulic installations at the Bakshabad, Alikinai and Lashkagar sites as well as their approximate costs.

TABLE 46 - FARAH RUD BASIN - QUANTITIES OF MAIN WORK ITEYS AND COST OF PROJECTED RESERVOIRS

\begin{tabular}{lcccc}
\hline No. Description & Unit & Bakshabad & Alikinai & Lashkagar \\
\hline 2 & 3 & 4 & 5 & 6 \\
\hline
\end{tabular}

Quantities of Work

1. Removal of Rock thou. $\mathrm{m}^{3} \quad 137 \cdot 2$

109.9

971.6

2. Removal of gravel from riverbed

"

"

3. Tunnelling

4. Cofferdams

5. Saddle Dam
"

11
73.5

76.6

53.5

70.6
239.8

114.3

134.2

61.8
1.9

104.5

40.3 
TABLE 46 (Cont.)

\begin{tabular}{|c|c|c|c|c|c|}
\hline No. & Description & Unit & Bakshabad & Alikinai & Lashkagar \\
\hline 1 & 2 & 3 & 4 & 5 & 6 \\
\hline \multicolumn{6}{|c|}{ Quantities of Nork } \\
\hline & Dam conoreting & thou. $m^{3}$ & 313.2 & 763.0 & - \\
\hline 7. & Ferro-concrete dam facing & $"$ & 3.0 & 1.8 & - \\
\hline & $\begin{array}{l}\text { Concrete lining of diversion } \\
\text { tunnels }\end{array}$ & $"$ & 20.8 & 30.5 & 104.5 \\
\hline & Gates, anchors and hoists & tons & 800.0 & 780.0 & 800.0 \\
\hline 10. & Power equipment & Kw & $24,000.0$ & $26,000.0$ & $32,000.0$ \\
\hline 11. & Rookfill for dam body & thou. $\mathrm{m}^{3}$ & - & - & 927.0 \\
\hline 12. & $\begin{array}{l}\text { Concreting of power house under- } \\
\text { water foundations }\end{array}$ & $"$ & - & - & 2.9 \\
\hline 13. & Ferro-ooncrete dam facing & " & - & - & 18.8 \\
\hline \multicolumn{6}{|c|}{ Building Materials } \\
\hline 1. & Timber & $"$ & 40.0 & 30.0 & 25.0 \\
\hline 2. & Cement & thou. tons & 84.0 & 200.0 & 32.0 \\
\hline 3. & Metal & $n$ & $5 \cdot 5$ & 2.8 & 2.4 \\
\hline \multicolumn{6}{|c|}{ Building Bquipment } \\
\hline & Various exoavators & pcs. & 10.0 & 15.0 & 12.0 \\
\hline & Concrete mixing plant & $"$ & 1.0 & 3.0 & - \\
\hline & Concrete pumps, $20 \mathrm{~m}$ capacity & $n$ & 5.0 & 8.0 & 2.0 \\
\hline & $\begin{array}{l}\text { Lorries and dump trucks, general } \\
\text { capacity of }\end{array}$ & tons & 500.0 & 700.0 & $1,500.0$ \\
\hline & Bulldozers & pos. & 10.0 & 12.0 & 12.0 \\
\hline & Motor rollers, 10 tons & " & 5.0 & 5.0 & 8.0 \\
\hline \multicolumn{6}{|c|}{ Cost of Hydraulic Installations } \\
\hline & $\begin{array}{l}\text { Total cost of the installations } \\
\text { as a whole. }\end{array}$ & $\$$ thou. & $15,550.0$ & $30,406.0$ & $16,370.0$ \\
\hline
\end{tabular}


The estimation of construction costs in Afghanistan, without knowing the current rates, is extremely difficult. Therefore, the construction costs for the Bakshabad, Alikinai and Lashkagar have been determined on a very approximate basis and are given merely to compare the alternative reservoirs for the Farah Rud basin, in accordance with the established volume of work.

The Bakshabad reservoir is the least expensive and the nearest to the irrigated lands, and it can be recommended for water control purposes, to ensure irrigation development on an area of over 60,000 hectares in cther words, more than adequate for the irrigable land in the Farah Rud Basin, 1.0. 59,200 ha.

Volume V - Dams and Reservoirs - gives a desoription of the organization and execution of construotion work, priorities, local quarries, and of some particulars of each of the various installations.

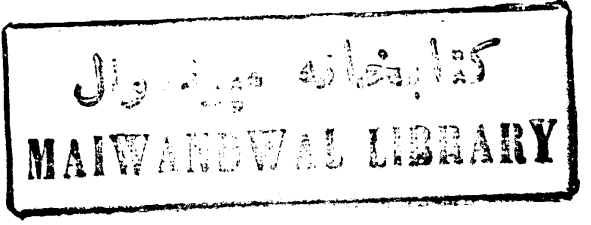




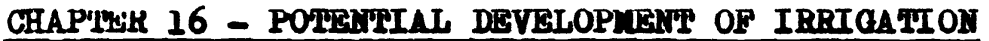

1. Shortoomings in Irrigation Development. The main shortcomings in the irrigated agriculture of the Farah Rud valley are as follows:

1) Lack of proper control over water distribution, which leads to an excessive water intake during the flood period, flooding of the adjoining land and an increase of the groundwater level. During the low period, the river flows are entirely taken for irrigation and only return flows come down to the lower valley. This causes damage to or loss of crops in the lower valley.

i1) The rise of the ground water levels brings about waterlogging in low areas and intensive salinization. Considerable acreages have fallen out of cultivation and some lands have been abandoned.

iii) The sharply-peaked Farah Rud flow regime contributes to these shortcomings, and makes it necessary to grow primarily grain crops.

iv) Because of lack of water for irrigation and a shortage of manure, in order to maintain the fertility of the lands it is necessary to use a crop-fallow system whereby only a third of the area is sown and the rest is left fallow.

In the light of this situation it would be necessary:

1) To bring order to the water distribution system, for which reconstruction of the irrigation network would be needed.

ii) To fight the ever-progressing salinization of the irrigated lands, by building a system of collector-drains. This drainage system should be laid out in such a way that the lands could be drained gradually without waiting for the completion of all the work.

iii) Further to develop irrigation in the valley and change towards a more intensive economy, by controlling the water of the Fas dh Rud, thus increasing the supply for irrigation purposes during the low water period.

2. Land Reserves. The irrigable areas in the Farah Rud basin are shown in Table 47. 
TABLE 47 - FARAH BWD - LAND CLASSES AND THEIR LOCATION

\begin{tabular}{|c|c|c|c|c|c|c|c|c|c|}
\hline & & \multicolumn{2}{|c|}{$\begin{array}{l}\text { At Daulatabad } \\
\text { and Dezak }\end{array}$} & \multicolumn{2}{|c|}{$\begin{array}{l}\text { Between Diahk } \\
\text { and Farah }\end{array}$} & \multicolumn{2}{|l|}{ At Juwain } & \multicolumn{2}{|c|}{ Totals } \\
\hline & & Hectares & $\%$ & Hectares & $\%$ & Hectares & $\%$ & Hectares & $\%$ \\
\hline $\begin{array}{c}\text { Class } \\
\text { " } \\
"\end{array}$ & $\begin{array}{l}2 \\
3 \\
4 \\
5\end{array}$ & $\begin{array}{l}5000 \\
- \\
- \\
-\end{array}$ & $\begin{array}{c}8.4 \\
- \\
- \\
-\end{array}$ & $\begin{array}{r}25,000 \\
2,600 \\
5,800 \\
14,900\end{array}$ & $\begin{array}{r}42.3 \\
4.4 \\
9.8 \\
25.2\end{array}$ & $\begin{array}{r}1740 \\
850 \\
1800 \\
1500\end{array}$ & $\begin{array}{l}2.9 \\
1.4 \\
3.0 \\
2.6\end{array}$ & $\begin{array}{r}31,740 \\
3,450 \\
7,600 \\
16,400\end{array}$ & $\begin{array}{r}53.6 \\
5.8 \\
12.8 \\
27.8\end{array}$ \\
\hline Totals & & 5000 & $8.4 \%$ & 48,300 & $81.7 \%$ & 5890 & $9.9 \%$ & 59.190 & $100.0 \%$ \\
\hline
\end{tabular}

It should be pointed out that the Juwain lands form a separate area situated about $80 \mathrm{~km}$. below the city of Farah. It would be reasonable to provide this area with water through the use of the return flow from the drainage-collector system of the main land block situated between Dishk and Farah. However, in preparing water control computations, the water supply for this area has been allowed for in full.

Table 48 gives the land classification of the main area situated between Dishk and Farah with the areas on the left and the right banks shown separately.

TABLE 48 - PARAH RUD - MAIN LANDS ON RIGHT AND LEFT BANKS

\begin{tabular}{lcrr} 
Iand Class & Loft Bank & Right Bank & Total \\
\cline { 2 - 4 } II & 910 & 2,290 & 3,200 \\
II A & 3,220 & 4,380 & 7,600 \\
II TA & 4,100 & 10,100 & 14,200 \\
\hline Total II & 8,230 & 16,770 & 25,000 \\
III A & 1,130 & 1,470 & 2,600 \\
IV A & 2,730 & 5,800 & 5,800 \\
V A & 12,170 & 14,900 \\
\hline Total & 12,090 & 12,170 & 48,300 \\
\hline
\end{tabular}


These areas heve been adopted in working out an irrigation developwent scheme in the Farah Rud basin on the Dishk-Farah stretch.

3. Regime of Irrigation Water Supply. The following regime of water supply per hectare of irrigable lands has been adopted:

\begin{tabular}{llll} 
Jan. $-800 \mathrm{~m}^{3}$ & Apr. $1,000 \mathrm{~m}^{3}$ & July $-2,000 \mathrm{~m}^{3}$ & Oct. $-780 \mathrm{~m}^{3}$ \\
Feb. -890 " & May $-800 "$ & Aug. $-2,000 "$ & Nov. $-1,000$ " \\
Mar. $-1,150$ " & June $-1,800$ " & Sept.- 1,200 " & Dec. - 830 " \\
\hline
\end{tabular}

$$
\text { Total: } \quad 14,250 \mathrm{~m}^{3}
$$

It should be noted that the above average irrigation requirement of $14,250 \mathrm{~m}^{3}$ per hectare (at the point of water intake from the river), taking into account canal and evaporation losses, does not cover the quantities of water needed for initial leachings. However, as the new lands are to be gradually develoned, it would not be necessary to allow specially for the leaching, or to provide an extra margin in the discharge capacity of the irrigation canals.

4. Irrigation Water Requirements. In accordance with the above-mentioned average irrigation requirements, the following regime will have to be established for the total water supply for an area of 59,200 hectares in the Farah Bud valley:

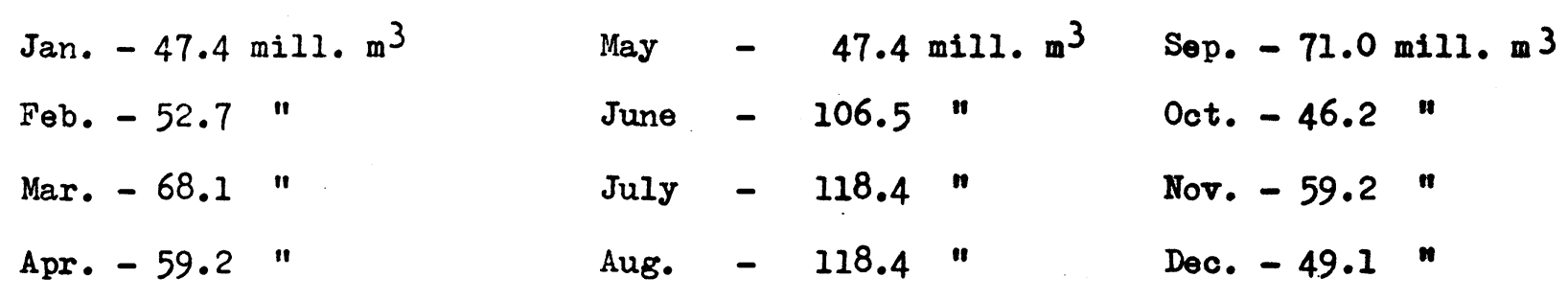

$$
\text { Total: } \quad 843.6 \mathrm{mill} \cdot \mathrm{m}^{3}
$$
below.

These water consumption values are used in further water control calculations

5. Irrigation Development Scheme. To illustrate the main principles of building a prospective irrigation system in the basin, and to investigate the required quantities of work involved in its construction, a draft design has been prepared for the Dishk-Farah lands with an area of 48,300 hectares.

In prevaring the design, the drawbacks of the present irrigation, were taken into account, and the following principles were established:

1) Because measures for the prevention of waterlogging and salinity will be most important for irrigation development, these measures should be started immediately.

This would call for the use of the Farah Rud bed as the main drainage collector, making it possible to carry out the drainage of the existing irrigated areas without waiting for the completion of their full reconstruction, and thus to ensure this 
reconstruction in stages.

2) The use of the Farah Rud bed as the main collector determines the position of the main canals, which must follow the external boundaries of the area to be irrigated.

3) The headworks (barrage) should be built $2 \mathrm{~km}$. above Dishk village. In view of the fact that the river transports a large quantity of suspended load, especially during the flood period, it is necessary to arrange for silt control at the head intake structure. This could be achieved by creating a crosswise circulation of the flow through a curved approach to the headworks. In such a case, the intake must be on one bank. As more water will enter the right-bank canal, the intake for the whole should be concentrated on this bank, and from it a culvert syphon housed in the heedworks structure should carry water to the left bank canal.

The layout of the irrigation scheme based on these principles, is shown in Drawings Nos. 12 and 17 indicating the irrigation network and the longitudinal profiles of the canals.

In accordance with the irrigation requirements and the distribution of the areas between the two banks, the maximum estimated intake of the right bank canal is $27.0 \mathrm{~m} / \mathrm{sec}$, and that of the left bank canal is $9.0 \mathrm{~m}^{3} / \mathrm{sec}^{\text {. }}$

With a safety margin of $20 \%$, the design capacities of the canals would be respectively equal to $38.4 \mathrm{~m}^{3} /$ sec. and $10.8 \mathrm{~m} / \mathrm{sec}$.

Particulars of the planned distribution network, includirg the areas assigned to various distributary canals, and their estimated normal and maximum discharges, and lengths, are given in Volume $V$.

The average slope of the valley down the river is about $1.5 \mathrm{~m}$. to a kilometre. The elevation difference between the head and the tail of the right-bank main canal comes to $55.0 \mathrm{~m}$. , and with its length being $43.2 \mathrm{~km}$, the average gradient is equal to 0.00127 . The fall of the left-bank canal is $36.5 \mathrm{~m}$. and its length is $26.4 \mathrm{~km}$. giving an average gradient of 0.00138 . The existence of such gradients on the canals would require a few drops to reduce the water slopes and velocities of flow.

The drops will be located at the offtakes of distribution canals. Fourteen drops with a total fall of $31.24 \mathrm{~m}$. are planned on the right bank canal, the maximum drop being $4.03 \mathrm{~m}$. and the minimum drop $0.77 \mathrm{~m}$. The left bank main canal has 7 drops with a total fall of $13.9 \mathrm{~m}$. , the maximum drop being $2.73 \mathrm{~m}$. and the minimum drop $1.20 \mathrm{~m}$.

The drops will necessitate the removal of considerable volumes of earth, especiaIIy from the right bank canal. In the next stage of design the selection of an economically justifiable drop height would be necessary, through comparison of the cost of building drops with that of excavation from the canal.

6. Quantities of Main Work Items and Costs. To find out the quantities of work for the distribution network, two distributors have been designed, PR-8 and LR-5. Parallel to the distributors collector channels have been planned which will take water from the drainage network. 
The collectors PK-7 and $\mathrm{LK}-4$ are expected to be used as escapes from the main canals, having in mind the possibility of passing through them up to $50 \%$ of the canal reaching their points of offtake. As the water will be passed within a very short lapse of time, no special deepening of the channels would be required.

The estimation of the quantities of work for the main, distributor and collector network has resulted in the following specific indices per hectare of irrigated areas

1. Main canals:

$\begin{array}{lrll}\text { Excavation } & 35.0 \mathrm{~m}^{3} & \text { per hectare } \\ \text { Banking } & 8.7 & " 1 " \\ \text { Concrete } & 1.3 & " & "\end{array}$

2. Distributor network:

$\begin{array}{lrll}\text { Excavation } & 3.0 \mathrm{~m}^{3} & " & " \\ \text { Banking } & 12.3 \mathrm{n} & " & " 1 \\ \text { Concrete } & 0.4 \mathrm{n} & \text { " }\end{array}$

3. Collector network:

$\begin{array}{lrll}\text { Excavation } & 59.1 \mathrm{~m}^{3} & " & \\ \text { Concrete (pipes) } & 0.3 \mathrm{n}\end{array}$

The specific quantities of work for the minor irrigation and drainage network have been based on the data estailished in designing the irrigation soheme in the Herat valley where designs of typical plots were worked out, giving details of all the quantities of construction work. These indices to an area of one hectare are given below:

4. Irrigation network:

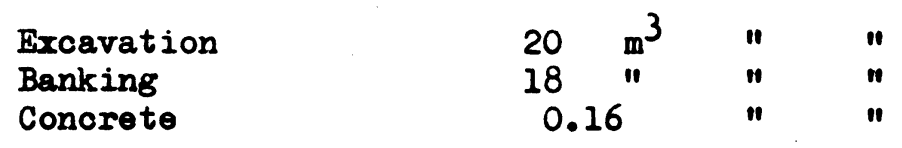

5. Water colleotor network:

Excavation* $80 \mathrm{~m}^{3} \quad " \quad$

* In the Herat valley with its limited development of the drainage network, the excavations are $40 \mathrm{~m}^{3}$ per hectare. For the Farah valley this figure has been doubled.

6. Field Levelling:

7. Road Network:
$85 \mathrm{~m}^{3} \quad " \quad$

$0.06 \mathrm{~m}^{3} \quad 1 \quad$

6 lin. m.

40 lin. $m$.

8. Afforestation belts, with trees and 7.1 lin. m. bushes planted four deep. 
Sunming up all the specific quantities of work per hectare, the following figures result:

\section{Earthwork}

$\begin{array}{lrl}\text { Excaration } & 282.1 \mathrm{~m}^{3} \\ \text { Banking } & 39.0{ }^{\prime \prime} \\ \text { Concrete } & 2.22 "\end{array}$

Serious difficulties exist in estimating the costs of construction work. Afghanistan lacks wide construction experience and therefore has no authorized quotations for varicus types of work. horeover all the transportation is effected by hired motor-cars, draft or pack animals. Nor are there any established transportation rates. At the same time the construction will require considerable amounts of non-local materials that would have to be transported over great distances. Based on the scanty data available on the costs of individual work items for the projects already completed or still under way in afghanistan, and assuming as reasonable the following rates per $\mathrm{m}^{3}$ of the main items, such as:

Excavation
Banking
Concreting

$$
\begin{array}{r}
\$ 0.5 / \mathrm{m}^{3} \\
\$ 1.0 / \mathrm{m}^{3} \\
\$ 100.0 / \mathrm{m}^{3}
\end{array}
$$

the total cost of the irrigation network for an area of 59.2 thou. hectares would be:

$$
\begin{array}{lrr}
\text { Excavation } & 282.1 \times 59.2 \times 0.5=\$ 8.35 \text { million } \\
\text { Banking } & 39.0 \times 59.2 \times 1.0=\$ 2.31 \text { million } \\
\text { Concreting } & 2.2 \times 59.2 \times 100.0=\$ 13.14 \text { million }
\end{array}
$$

\begin{aligned} \hline Total & $=\$ 23.80$ " \\ $\begin{array}{l}\text { Work not specif- } \\ \text { ied in detail - } 50 \%\end{array} & =\$ 11.90 "$ " \\ Intake headworks on the Farah Rud & $=\$ 4.60 " ~\end{aligned}$

Consequently, the estiulated expenditure for irrigation of one hectare of the Farah Rud lands (without the reservoirs) would amount to 680 . 
CHAPTER 17 - POTENTIAL DEVELOPMENT OF HYDROPOWER

The water balance calculations carried out within the frame of the water control scheme, have indicated that in developing irrigation in the Farah Rud basin on an area of 59.2 thousand hectares, it would be sufficient to regulate runoff in one of the three reservoirs under consideration.

It is therefore necessary to determine the power potential of each reservoir in order to ascertain which is the best in this respect.

Volume V - Dams and Reservoirs - gives estimations of the possible capacities of the power outputs of the power stations at Bakshabad, Alikinai and Lashkagar for years of $50 \%$, $75 \%$ and $20 \%$ probability.

On the basis of these data, it would be possible to determine in the preliminary estimates, with a considerable degree of accuracy, the normal annual power output of the stations as the mean of power outputs for low, medium and high years. These and other main indices for the hydropower stations are quoted in the following table:

TABLE 49 - FARAH RUD RHSERVOIRS - HYDROPOWER RESOURCES

\begin{tabular}{llllll}
\hline $\begin{array}{l}\text { Name of } \\
\text { Station }\end{array}$ & $\begin{array}{l}\text { Rated } \\
\text { capacity } \\
\text { (thou. Kw.) }\end{array}$ & $\begin{array}{l}\text { Normal ann- } \\
\text { ual power } \\
\text { production } \\
\text { (mill.Kw-krs.) }\end{array}$ & $\begin{array}{l}\text { Mean dis- } \\
\text { charge } \\
(\mathrm{m} 3 / \mathrm{sec})\end{array}$ & $\begin{array}{l}\text { Nean } \\
\text { Head } \\
(\mathrm{m})\end{array}$ & $\begin{array}{l}\text { Distance from } \\
\text { Farah Town } \\
(\mathrm{km})\end{array}$ \\
\hline Bakshabad & 24.0 & 132.6 & 41.9 & 52.4 & 96 \\
Alikinai & 26.0 & 143.0 & 41.0 & 58.0 & 116 \\
Lashkagar & 34.0 & 188.2 & 39.2 & 79.2 & 168 \\
\hline
\end{tabular}

From the above data it could be seen that the Bakshabad hyaropower station possesses the smallest potential resources. The Alikinai power output would exceed that of the Bakshabad station by $7.8 \%$, whereas the Lashkagar station would generate $41 \%$ more power than the Bakshabad station.

As the hydropower stations are not the main components of the complex, the final selection of a recommended version would be made when deciding on the whole complex. The above data would be of help in choosing the reservoir version. 


\section{CHAPTHE 18 - COHCLUSIOIS AND RFCOMAHIDATIOIS}

1. The avallability of free irrigable lands in the Farah fud valley as well as of water resources now only partially utilized without water control meawures, and of ample man-power resources in the valley, are factors in favour of planning irrigation development in the very near future, in order to boost the economy and culture in this part of the country.

2. It has been established that lands of Classes II and III acoount for : 27,600 heotares in the Farah valley, 5,000 hectares at Deulatabad and 2,540 hectares in Juwain. These lands need only water. Their general charaoter is ouch that they would require the minimum amount of work in measures of reclamation.

To develop irritation on these lands, construction of a reservoir would be required since under the present conditions without water control only $50 \%$ of these lands are being irrigated.

Class IV lands in the Farah valley (5,800 heotares) and in the Juwain $(1,800$ hectares) are also suitable for irrigated agriculture, but their present condition would require speoial reclamation.

Class $\nabla$ lands (14,900 hectares in the Farah valley) occupy now a special position. All these lands were irrlgated in the past and were later abandoned for cultivation because of their high salinity and alkalinity. Restoration of these lands is quite possible, but it would be necessary to carry out much large-scale reclamation involving in the first place the establishment of a drainage system and also the provision of water for reaching purposes for a number of years.

However, in planning a dam and reservoir on the Farah Rud, the capaoity of caloulatione should also take into account the possible reclamation of Class $V$ lands in the future. In this case it should be necessary to carry out teohnical and economic computations to justify restoration of these lands.

3. Under the present conditions, irrigated agriculture mainly consists of grain orops which oocupy over $80 \%$ of all the annually irrigated areas, with all the summer crops having a scant $20 \%$ share. Such a proportion of orops is necessitated by the natural regime of the river throughout the year, and the peasant must adjust himself to this regime. Anj change in the regime may be possible only by regulation of the run-off.

The provision of irrigation water to lands of Classes II, III, and IV and the introduction of more profitable industrial crops, should be one of the main tasks in planning irrigation development in the Farah valley where unused land, water and man-power resources are available, to say nothing of the favourable climatio condittons of this valley for the development of valuable orops which are already required in quantity for the country's own developing industries.

4. Only an insignificant part of the lands is sown and irrigated intensively. The greater part of the lands suitable for irrigated farming is used only once in 2-3 years. To reduce the fallow period and to increase the irrigated area, it would be necessary first to have additional water for irrigation waters. In all, irrigation development will requires 
a) Improvement or reconstruction of the existing irrigation systems

b) Construction of regulating hydraulic structures on the canal

c) Construction of drainage and collector-disposal system

d) Regulation of water use and distribution

e) Efficient management of the valley water resources, and also registration of land and irrigation water use.

Establishment of control over the distribution of the available irrigation water must be the first step on the way to irrigated farming development in the valley. At the same time, the introduction of mineral and organic fertilizer into the soil, as well as the application of modern techniques of cultivation should be given priority in the improvement of agriculture.

Even under the existing conditions, with shortage of irrigation water, and with vast areas of waste lands kept fallow, almost $50 \%$ of the valley area is saline in varying degrees and has high levels of groundwater. In the absence of proper control over the use of irrigation waters, salinity would clearly increase even under the existing conditions, and the more so if, in the future, the water intake is increased as a result of a reservoir. The more water is fed to the area in the upper valley, the more would soil salinization increase and the ground water levels rise in the lower valley. Therefore, to prevent the abandonment of lands from cultivation, and to maintain their fertility, the necessity of balancing water use through proper control over irrigation, and of establishing the drainage and collector network over the greater part of the valley is once again emphasized.

5. In the Farah valley, as in the valley of Herat, summer crops suffer heavily from the winds which, at velocities up to $40 \mathrm{~km} . / \mathrm{hr}$. considerably reduce during the summer months the productivity of the agricultural crops.

To reduce the harmful effects of the wind in the valley over a wide area, it would be necessary to provide special wind-protective belts of trees and bushes. These would also reduce and possibly eliminate soll erosion caused by the wind, as well as improve the valley microclimate.

6. A number of suggestions directed at improvements in the existing farining and development of additional irrigated agriculture in the Farah valley are given in the report by 0.T. Osgood - "On the Use of the Land and Water Resources of the Farah Area". These recommendations deserve much attention on the part of the Government authorities, and particularly of the Ministry of Agriculture.

7. Development of the land and water resources of the Farah Rud valley in accordance with the proposed irrigation scheme, is possible, provided that the run-off is regulated in accordance with the calculations for water control.

8. The irrigation development scheme is planned for the area of 59,200 hectares by gravity, with easy conditions of water intake from the river. The valley has favourable topographical conditions for the construction of an irrigation distribution network. However, the existence of over 15,000 hectares, which are saline in various degrees would require comprehensive hydrogeological investigations in the future throughout the valley, with the object of designing and constructing a satisfactory drainage system. 
9. The surveys and preliminary designs of the three reservoirs at Bakshabad, Alikinai, and Lashkagar have established that by constructing one of these it will be possible to increase the present irrigated area by about 45,000 hectares, up to about 60,000 hectares, under crop rotations including up $50 \%$ of industrial crops.

Of the three reservoirs, that at Bakshabad is the nearest to the irrigated areas, as well as the least expensive, and therefore it is recommended for water control in the Farah Rud basin. The cost of this reservoir would amount to US $\$ 15.55$ million, equivalent to a specific expenditure of $\$ 262$ per hectare of irrigated area of $69,200 \mathrm{ha}$.

The total cost of irrigation development over this area comes to US $\$ 40.30$ million, equivalent to a specific expenditure of $\$ 680$ per hectare.

Consequently, the total of irrigation works in the Farah Rud valley, including the cost of runoff regulation in the Bakshabad reservoir, for the entire area of 59,200 hectares would amount to US\$ 55.85 million, equivalent to US $\$ 942$ per hectare.

Further particulars of the irrigation development envisaged in the valley of the Farah Rud are given in Volune $\nabla$ of this Report.

20. The potential hydropower of the three alternative storage projects is estimated t. 3 follows:-

\begin{tabular}{lccccc} 
Project & $\begin{array}{c}\text { Rated } \\
\text { Capacity } \\
\text { (Thous. KW) }\end{array}$ & $\begin{array}{c}\text { Normal } \\
\text { Annual } \\
\text { Production } \\
\text { (Milln. KW-Hrs) }\end{array}$ & $\begin{array}{c}\text { Mean } \\
\text { Discharge } \\
\left(\mathrm{m}^{3} / \mathrm{s}\right)\end{array}$ & $\begin{array}{c}\text { Mean } \\
\text { Head } \\
(\mathrm{m})\end{array}$ & $\begin{array}{c}\text { Distance from } \\
\text { Farah Town } \\
(\mathrm{Km})\end{array}$ \\
\hline Bakshabad & 24.0 & 132.6 & 41.9 & 52.4 & 96 \\
Alikinai & 26.0 & 143.0 & 41.0 & 58.0 & 116 \\
Lashkagar & 34.0 & 188.2 & 39.2 & 79.2 & 168 \\
\hline
\end{tabular}

All can develop power on a large scale, Lashkagar having the greatest potential and Bakshabad the least. But considerations of power are much less important than the other factors mentioned in 9 above, in deciding which of the three alternatives should be seleoted. 


\section{STCIIOI IV}

\section{KABUL BASIII}

\section{Chapter 19. BASIN DESCRIPTION}

1. General Information: The Kabul Basin, in the north-east of Afghanistan, is asymmetrical, the left bank tributaries being much more important than those on the right bank. The Kabul river has a total length of $360 \mathrm{Km}$. within Afghanistan, and another $140 \mathrm{Km}$. In Pakistan before it joins the Indus. The catchment area within Afghanistan, including the Kunar river, is $75,390 \mathrm{Km}^{2}$. To the north, the basin is bounded by the Hindu Kush, whose snows feed the Panjahir flowing south-west, and the Chorband flowing north-east to join it. After their confluenoe, the Panjshir, whose catohment area is $14,900 \mathrm{~km}^{2}$, receives a amall river, the Shakrar Dara, on its right bank, before it flows into the Kabul river.

The Kabul river itself rises at the foot of the Unai Pass, being bounded on the north by the Kuh-i-Baba range of Central Afghanistan. It flows eastwards, and above Kabul city is known as the Bala Maidan. Below the city, it is joined from the southwest by the Logar (catchment area $11,430 \mathrm{~km}$ ), receiving the Panjshir some $40 \mathrm{~km}$. further east. Other important left-bank tributaries are the Alishang, with a catchment of $7,900 \mathrm{~km}^{2}$ and the Kunar, which has a catohment of $26,810 \mathrm{~km}^{2}$. The two last, and the Surkhab, a much smaller right-bank tributary, were not included in the Project surveys.

There are also many minor tributaries, which are usually dry during the summer. During the heavy rains, however, at the end of winter and in spring, floods carrying much debris may occur on these streams, doing extensive damage to the peasants' farms. Thus, In 1960 the specific maximum discharges of the streams below the Surkhab mouth reached over 2,000 litres/sec. per $\mathrm{km}^{2}$.

All the rivers of the basin are widely used for irrigation. As a result, even some major tributaries, such as the Logar, Surkhab and the Upper Kabul may almost dry up during the summer period of intensive water consumption.

In recent years, the waters of the Kabul river have been used for the generation of power. Up to the present, the Sarobi power plant has been the largest, with a capacity of $22,000 \mathrm{kw}$. Now, the largest station in Afghanistan, with a capacity of $60,000 \mathrm{Kw}$, is under construction on the Kabul river at Naghlu.

2. Climate. Three climatic zones can be distinguished in the Kabul basin; the plains and foothills, the zone of medium elevation from 1000 to $2500 \mathrm{~m}$., and the alpine zone.

The first zone includes the Jalalabad valley. Though this valley is at the same latitude as Kabul and Herat, its climate is quite different, on account of their elevations and reliefs.

From the north the Jalalabad valley is protected from cold winds by high mountains. At the same time, it is affected by the warm monsoon from India. These conditions make its climate the warmest in Afghanistan. Here January, the coldest month, has a mean monthly air temperature of $5^{\circ} \mathrm{C}$, and July the hottest month, over $33^{\circ} \mathrm{C}$. The range of daily air temperatures may be from 20 to $35^{\circ} \mathrm{C}$. Sometimes, late in the autumn and in winter, mild frosts occur at night. For instance, in January 1962, the Jalalabad met. station recorded a minimum air temperature of $-4^{\circ} \mathrm{C}$.

In the second zone, that is, at the height of Kabul, Karazemir and Ghazni, over $1500 \mathrm{~m}$. the mean daily air temperatures in the summer period rise to $20-25^{\circ} \mathrm{C}$ between June and August, are about 10-200C in the spring and autumn, and fall to0 $-5^{\circ}$ in winter. In the upper portion of this zone, the three winter months of December to February have mean monthly temperatures below freezing point. 
In the alpine zone, the duration of the period when mean monthly temperatures are below zero increases substantially, and reaches 6 months in the area of the southern Salang meteorological station. Here the mean monthly temperatures in the summer months fluctuate within $+9-12^{\circ} \mathrm{C}$.

Estimations indicate that above a haight of about $4,500 \mathrm{~m}$. in the Hindu-Kush mountains, mean monthly temperatures belor zero prevail throughout the year.

a) Air Temperatures. Table 50 belor shows data for five meteorologioal. stations, and also computed air temperatures for an elevation of $4,000 \mathrm{~m}$.

\section{TABLE 50}

RABUL BASTN - MEAN ANNUAL AIR TERUPERATURES

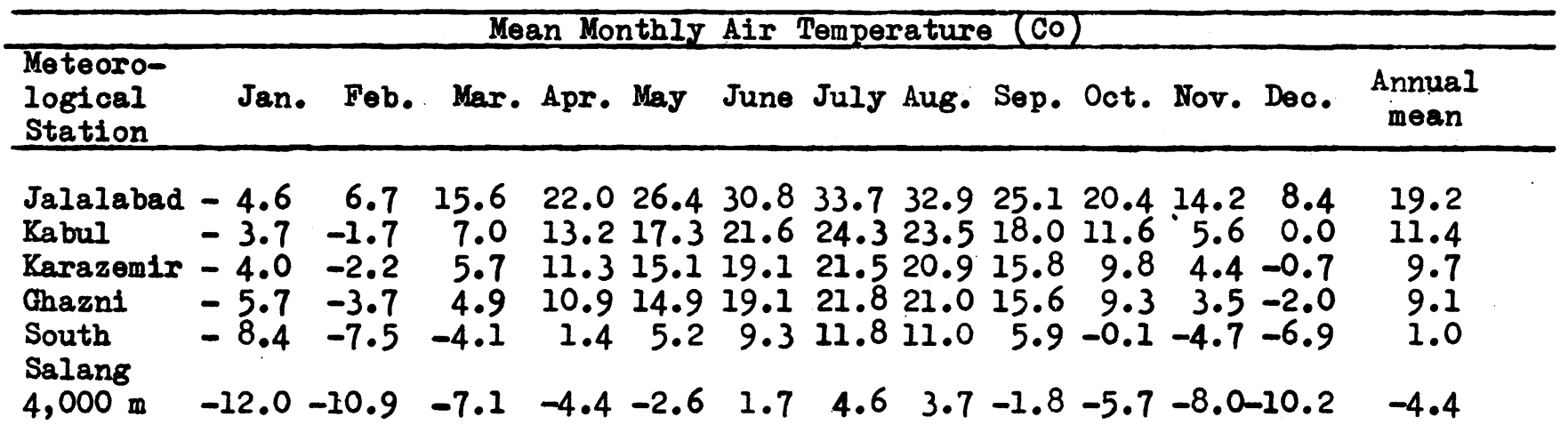

b) Precipitation In the alpine zones precipitation occurs mainly in the months of November to May. However, in contrast to other areas in Afghanistan, in the Kabul basin precipitation takes place also during the summer period, though not in significant amounts. This precipitetion is caused by the monsoon from India. As in many other mountain regions, precipitation here increases with height.

A peculiarity in the distribution of precipitation over the basin is the fact that in its northern part, that is on the left bank of the river, precipitation is twice to three times that in its southern part. This is explained by the fact that the surrounding mountain ranges are higher on the north than on the south. Air masses passing over the basin area only slightly saturated, part with their moisture more easily over the higher portions of the basin. As a result, the left-bank tributaries of the Kabul carry considerably more water than those on the right-bank.

In the plains and foothills precipitation throughout the year occurs mainly as rainfall although in winter time there are quite frequent snow falls never forming any lasting snow cover.

In the alpine zone precipitation occurs solely in the form of snow. Over the greater part, a lasting snow cover persists throughout the cold period and only disappears by the middle of the summer (June-July). In the Kunar basin, there are glaciers and eternal snows. 
Table 51 below shows figures of the mean monthly precipitation for a long-term period at the five meteostations.

TABLE 51

\section{KABUL BASIN - MEAN MONIHLY PRECIPITATION}

\begin{tabular}{|c|c|c|c|c|c|c|c|c|c|c|c|c|c|}
\hline \multirow{2}{*}{$\begin{array}{l}\text { Name of } \\
\text { Station }\end{array}$} & \multirow{2}{*}{\multicolumn{13}{|c|}{ Monthly Mean Precipitation in MM. }} \\
\hline & Jan & Feb & $\operatorname{Mar}$ & Apr & May & June & July & Aug & Sep & Oct & Nov & & \\
\hline $\begin{array}{l}\text { Jalalabad } \\
\text { Kabul } \\
\text { Karazemir } \\
\text { Chazni }\end{array}$ & $\begin{array}{r}25.2 \\
42.0 \\
48.0 \\
39.1\end{array}$ & $\begin{array}{l}25.2 \\
50.0 \\
57.0 \\
29.7\end{array}$ & $\begin{array}{l}29.7 \\
61.4 \\
69.0 \\
65.6\end{array}$ & $\begin{array}{l}54.0 \\
69.5 \\
78.8 \\
66.9\end{array}$ & $\begin{array}{l}10.0 \\
25.0 \\
28.0 \\
26.6\end{array}$ & $\begin{array}{r}0.8 \\
4.5 \\
4.6 \\
11.0\end{array}$ & $\begin{array}{r}6.7 \\
4.6 \\
4.8 \\
38.1\end{array}$ & $\begin{array}{l}4.9 \\
5.4 \\
6.0 \\
1.0\end{array}$ & $\begin{array}{l}8.9 \\
1.8 \\
2.0 \\
0.0\end{array}$ & $\begin{array}{r}40.0 \\
8.8 \\
9.5 \\
0.0\end{array}$ & $\begin{array}{l}18.2 \\
13.6 \\
15.0 \\
22.4\end{array}$ & $\begin{array}{l}19.0 \\
34.5 \\
38.3 \\
33.6\end{array}$ & $\begin{array}{l}242.6 \\
321.1 \\
361.0 \\
334.0\end{array}$ \\
\hline Salang & 102 & 132 & 190 & 280 & 58 & 8 & 9 & 11 & 4 & 17 & 27 & 77 & 910.0 \\
\hline
\end{tabular}

The figures for the Karazemir and South Salang stations have been adjusted to a 30-year period, whereas the figures for Kabul, Jalalabad and Chazni stations are based directly on the observed data over 30,8 , and 5-years respectively.

c) Evaporation Because of high air temperatures and low humidities in the Kabul basin, especially in its lower zones, rates of evaporation are high. In the absence of observations of evaporation from water surfaces in the various parts of the basin, estimated figures are given in Table 52, based on the air temperatures and humidities.

\section{TABLE 52}

KABUL BASIN - ESTIMATED MEAN MONTHLY EVAPORATION FROM WATER SURFACE

\begin{tabular}{lrrrrrrrrrrrrrrr}
\hline \multicolumn{10}{c}{ Mean Monthly Evaporation in mm } \\
\hline Station & Jan. Feb. Mar. Apr. May & June & July & Aug. & Sep. & Oct. & Nov. & Dec. & $\begin{array}{c}\text { Annual } \\
\text { (min) }\end{array}$ \\
\hline Jalalabad & 90 & 110 & 170 & 210 & 260 & 340 & 360 & 330 & 160 & 120 & 110 & 110 & 2370 \\
Kabul & 50 & 70 & 120 & 140 & 180 & 210 & 220 & 210 & 150 & 130 & 80 & 50 & 1610 \\
Karazemir & 40 & 60 & 110 & 140 & 160 & 180 & 200 & 180 & 130 & 100 & 70 & 50 & 1420 \\
Chazni & 30 & 50 & 100 & 140 & 180 & 190 & 200 & 190 & 140 & 100 & 60 & 40 & 1420
\end{tabular}

It is difficult to judge how closely these values approach the actual rates of evaporation. They can probably be safely used in the first stage of designing the hydraulic works, but they require to be checked by direct observations as soon as possible.

Although the Kabul basin is better covered by meteorological observations than the other parts of Afghanistan, it is still difficult to furnish more detailed descriptions of the climate, since the mountainous terrain with deep river valleys and high watershed ranges creates a large variety of conditions in different parts of the basin.

The climatic information given above is based on the data provided by seven meteorological stations with varying periods of observation series. Table 53 below lists these stations, their bearings, elevations and their respective years of observations. 


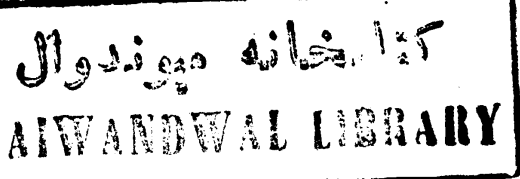

TABLE 53

METEOROLOGICAL STATIONS IN KABUL AREA

\begin{tabular}{|c|c|c|c|c|}
\hline \multirow{2}{*}{$\begin{array}{l}\text { Name of } \\
\text { Station }\end{array}$} & \multicolumn{2}{|c|}{ Co-ordinates } & Elevation & \multirow{2}{*}{$\begin{array}{l}\text { Years of } \\
\text { Observations }\end{array}$} \\
\hline & Latitude & Longitude & $\begin{array}{c}\text { above sea level } \\
(\mathrm{m})\end{array}$ & \\
\hline $\begin{array}{l}\text { Kabul } \\
\text { Karazemir } \\
\text { Kabul (Seraj) } \\
\text { North Salang } \\
\text { South Salang } \\
\text { Jalalabad } \\
\text { Ghazni }\end{array}$ & $\begin{array}{l}34^{\circ} 33^{\prime} \\
34^{\circ} 40^{\prime} \\
35^{\circ} 08^{\prime} \\
35^{\circ} 22^{\prime} \\
35^{\circ} 16^{\prime} \\
34^{\circ} 35^{\prime} \\
33^{\circ} 33^{\prime}\end{array}$ & $\begin{array}{l}69^{\circ} 12^{\prime} \\
69^{\circ} 05^{\prime} \\
69^{\circ} 15^{\prime} \\
69^{\circ} 03^{\prime} \\
69^{\circ} 03^{\prime} \\
70^{\circ} 27^{\prime} \\
68^{\circ} 25^{\prime}\end{array}$ & $\begin{array}{r}1763 \\
1822 \\
1628 \\
3350 \\
3100 \\
550 \\
2150\end{array}$ & $\begin{array}{r}30 \\
4 \\
1 \\
1 \\
1 \\
8 \\
5\end{array}$ \\
\hline
\end{tabular}

Analysis of the data obtained for these stations shows that the principal factor determining the climate is not the latitude and longitude of the various parts of the basin, but their elevations above sea level and their orography.

3. Vegetation and Fauna. The Kabul basin, like the majority of other parts of Afghanistan, is notable for its poor vegetation and animal life, as described in Chapter 3.,

However, in a number of valleys where rivers have formed narrow strips of flatter land with at least a scarce top soil, great efforts have been made to preserve and build up the soils, using every square meter for crops.

Trees found in the cultivated areas near centres of habitation include oaks, ashes,willows, poplars, conifers and palms, as well as fruit trees; grapes are also grown.

4. Population. According to official figures the population of Kabul Province is about $1.6 \mathrm{milli}$. This is one of the most densely nopulated provinces in Afghanistan, about 310,000 people inhabiting Kabul, the capital of the country. The population is varied in its national composition, Afghans comprising over $80 \%$.

The main occupations of the people are agriculture and the breeding of livestock, but about 15\% are employed in handicrafts, trade, industrial enterprises and civil service. As elsewhere in Afghanistan, the population is very unevenly distributed. In the mountains, which form some $70 \%$ of the total area, there is no resident population. The people are mainly settled in the valleys of the Kabul river and its tributaries, such as the Bala Maidan, Logar, Panjshir, Ghorband, and others, where the presence of soils and water make agriculture possible.

5. Roads and Means of Communication. The part of the Kabul basin covered by the Project, as compared with other parts of the country, has a quite well-developed network of roads of different grades usable by motor transport throughout the year. From the city of Kabul roads radiate in all directions, giving access to all regions of the country as well-as to the neighbouring foreign states. The northern part of the basin is linked by a first-class road to Jabal-Seraj, through Karabagh, Charikar and Gulbahar. Branches of this road, along the rivers Ghorband and Panjshir, have quite satisfactory gradients and sufficiently wide metalled surfaces. 
Towards the south-west runs the main trunk road to Ghazni, now being reconstructed with USA aid. Connected with this is a wide network of motorable dirt roads, which include that to the upper reaches of the Logar valley, where the Kajao reservoir may be built; this too can be used by motor vehicles throughout the year.

The damsite at Tangi Saidan on the Bala Maidan river (the upper Kabul river) is hardly yet accessible by motor transport, although it is only $16 \mathrm{Km}$. from Kabul city. To provide access to this site, a road $10 \mathrm{Km}$. in length will be required.

The eastern part of the Kabul basin has a first-class highway linking Kabul, through Jalalabad, with Peshawar in Pakistan. Access to western Afghanistan is either by the circular highway, or by the road through the mountains via Hazarajat, to.Herat, but this crosses very high passes and is tortuous, steep and rough; it is impassable in winter. (See Chapter 3, Section 8)

Most of the villages in the valleys of the Kabul river and its tributaries are connected with these highways by dirt roads, not everywhere motorable, which, especially on the mountain stretches, abound in steep rises, narrow tracks, and illdesigned and defective bridges. The construction of any hydraulic structures on the Kabul or its tributaries will undoubtedly involve the provision of access roads.

Motor transport carries the main types of building materials and equipment, consumer goods and other freights. $60 \%$ of it is owned by joint stock companies, and $40 \%$ by the state. A growing fleet of buses provides passenger transport within the province, as well as between provinces; over 2/3rd of all the motor fleet of Afghanistan is concentrated in Kabul and other towns of the Kabul province, although a considerable part of the internal traffic is still handled by pack animals.

In Kabul there are storage tanks capable of holding over 2,000 cu.m. of petrol, and a number of filling stations belonging to the Department of State Monopolies.

Kabul has a first-class international airport, served by many international airlines. The Ariana Airlines operate domestic flights between Kabul and Kandahar, Herat, Maimana, Maza-i-Sherif, Kunduz and Jalalabad.

Kabul is linked by telegraph and telephone land lines with all the provincial capitals, and has telephone communications with many district centres in the Province. There are also radio-telephone links with the provincial capitals, as well as radiotelegraph communication within the country and to foreign countries. 


\section{CHAPTER 20 - SOILS AND PRESENT IAND USE}

1. General Information. Vol. IV - Soils - provides detailed desoriptions of the main types of soils found in the Kabul basin based on chemical analyses of individual profiles as well as classifications of capability for irrigation and present land use. Here only a summary of the main features is given.

The soil surveys were limited to the valleys of the middle and lower Logar, the lower Ghorband, the middle Panjshir and the lower Bala-Maidan rivers. These lands are located in the central part of the Kabul province at altitudes of 1600 to $2000 \mathrm{~m}$ above sea level; they include the main agricultural areas, on ancient cultivated lands, lying in both narrow and wider valleys, filled with ancient glacier deposits or tertiary conglomerates of varying thicknesses. Over these lie recent deposits of river alluvia or piedmont-talus materials. All this mass of conglomerates, shingles and sand-clay deposits is in part covered with loess-like surface soils, largely in patches.

The surveyed area is surrounded by mountains formed of metamorphic rock. Except the relatively wide Charikar and Kabul depressions, all the valleys are in general narrow and elongated.

2. General Description of Soils. The surveyed soils of the Kabul valley and its tributaries vary considerably. A brief description is given below of the soils of each valley separately.

a) Ghorband, Panjshir and Shakar Dara valleys. The soils of these valleys have four well-pronounced features.

1) Mountain soils, grey-brown to brown, are of a medium texture, with a lime horizon. These soils are located on the upper terraces and, as a rule, are less intensively irrigated; their texture grows heavier with depth changing from sandy loam to loam.

The soil cover is rather thick and extends to a depth of 1.5 to $2 \mathrm{~m}$ or even more.

The terrain here is slightly undulating, and is sometimes eroded by gullies.

No salt formations are observed. The soils drain well vertically and horizontally. Some of these lands are irrigated and sown with wheat, but the major portion of them is unused because of lack of water.

2) River terraces - have a light texture, and contain no lime. These soils occupy the middle-level and lower river terraces, and are the most intensively irrigated and cultivated: none are left under fallow.

The soil is from 0.50 to $1.0 \mathrm{~m}$ thick, and mired in all horizons with well-rounded pebbles, the quantities of which decrease with depth. 
The terrain is relatively flat and slightly undulating. The drainage is good.

3) Piedmont soils have a light texture, and contain little or no lime. They usually occupy the upper parts of the surveyed valleys and adjoin the areas of talus materials or the outwash erosion fans. These soils usually occur in the narrow parts of the valleys, and also cover higher portions of the mountain slopes. They are terraced, and the majority of them are very intensively cultivated.

In their terrain, these lands are undulating and eroded. They drain well. Where there is water, intensive irrigation exists, these areas being, as a rule, taken up for orchards and vineyards.

4) Stony soils, talus and debris are usually located on mountain slopes, highly eroded by mountain streams and practically devold of any soil. Scattered piedmont patches with thin limy soils, whenever they occur, are intensively used for orchards and vineyards and irrigated by the mountain streams. These soils have sandy loamy to loamy textures.

b) Logar Valley. The soils surveyed in the Logar valley are mostly alluvially deposited, contain lime and have comparatively high $p H$ values. They are of three well-pronounced types:-

1) Upper brown soils of medium texture have a uniform profile with moderately light loamy top layer underlain with sandy loamy sub-soil to a depth of $1.5 \mathrm{~m}$. A compact layer of thick loam usually occurs underneath.

These soils usually adjoin eroded gravelly valleys and rocky mountain spurs.

Much of the area covered by soils of this type is rather even in terrain, but parts are subject to heavy erosion, due to their steep slopes. Both vertical and horizontal drainage is good. The solls are used for agriculture, but only in part, since water is not sufficient to irrigate the whole area.

2) Grej-Brown alluvial soils of medium texture, loany with a thiok irrigation horizon, are situated on the middle-level terraces, and, as a rule, are under intensive cultivation, with wheat grown as the main crop.

The drainage conditions of these soils are satisfactory.

3) Grey Hydromorphic solls are situated on the lower river terraces. They do not have good sub-soil drainage, and this results in high groundwater levels, up to depths from 0.3 to $1.5 \mathrm{~m}$. These lands have a slightly undulating terrain. The soils of this type are intensively irrigated and oultivated. 
c) Kabul Valley. The soils of the central Kabul valleys, around Kabul city, fall into five well-pronounced types, briefly described as follows:-

1) Grey-brown medium-textured lime soils occupy considerable parts of the higher areas. Parts of these lands are intensively irrigated, and wheat and barley are the main crops grown.

The major part of these lands, approximately 40,000 hectares, lie north of the Kabul airport, and at present have no water for irrigated agriculture. Some of these lands are hilly and eroded.

The texture of these soils varies from loamy to sandy loam. The structure is lumpy.

2) Limey soils of the river terraces of light texture are intensively cultivated and irrigated. The texture ranges from sandy loam to loam. Gravels occur in the lower horizons. These soils are generally not thick, and contain line.

3) Limey piedmont soils of light texture from sandy loam to sandy are observed at the foot of the mountains or on out-wash flats.

Along the hill slopes in the Paghnan area the soils are too thin and include rocky stony outcrops. Cultivated lands occur in patches.

The soils contain lime.

4) Grey-Brown Hydromorphic Soils of medium texture from loam to sandy loam. These lands as a whole are intensively cultivated and irrigated. There are, however, large areas partly waterlogged, with groundwater levels stand at 30 to $100 \mathrm{~cm}$ from the surface, for which reason they have been abandoned.

5) Brown soils, of medium texture in the mountain parts of the valley occur in the south-western part of the surveyed area. The soils range from fine landy loam to loam.

3. Land Resources. Table 54 shows the land resources in the basin of the Kabul river and its tributaries, in accordance with the classification given in Chapter 4, para 3.

\section{TABLE 54}

KABUL BASIN - LAND RESOURCES OF THE PART SURVEYED

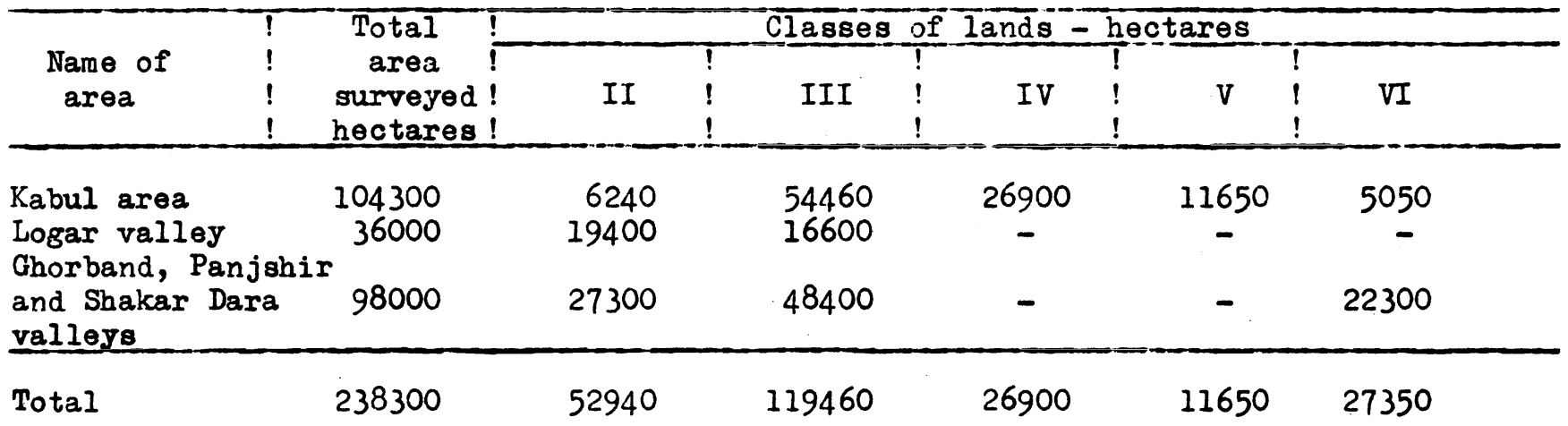


5. Land Use in Existing Conditions. The river valleys are mostly narrow, from $50 \mathrm{~m}$. to $1000 \mathrm{~m}$. wide, and lie at elevations of from 1600 to $2000 \mathrm{~m}$.among mountains of varying heights. However, such valleys as Kuh-i-Stan and Kuh-i-Daman are wide and reach $15 \mathrm{~km}$. across. These valleys are intensively cultivated and, therefore, are amongst the most densely populated areas in the country.

Table 55 gives a summary of the present use of the lands surveyed.

TABLE 55

KABUL BASIN - PRESENT ILAND USE

\begin{tabular}{|c|c|c|c|c|}
\hline \multirow[b]{2}{*}{ Description } & \multicolumn{4}{|c|}{ Gross Areas - Hectares } \\
\hline & $\begin{array}{l}\text { Logar } \\
\text { Valley }\end{array}$ & $\begin{array}{c}\text { Panjshir - Ghorband } \\
\text { and Shakar Dara } \\
\text { Valleys }\end{array}$ & $\begin{array}{l}\text { Kabul } \\
\text { Area }\end{array}$ & Totals \\
\hline \multirow{5}{*}{$\begin{array}{l}\text { 1. Lands intensively irrigated } \\
\text { 2. Lands intermittently irriga- } \\
\text { ted } \\
\text { 3. Lands of low value, used as } \\
\text { pastures } \\
\text { 4. Gravelly lands unsuitable } \\
\text { for irrigation }\end{array}$} & 15,500 & 38,400 & 44,350 & 98,250 \\
\hline & 20,500 & 36,300 & 46,550 & 103,350 \\
\hline & - & - & 8,350 & 8,350 \\
\hline & - & 23,300 & 5,050 & 28,350 \\
\hline & 36,000 & 98,000 & 104,300 & 238,300 \\
\hline
\end{tabular}

Apart from these surveyed areas numerous small plots are cultivated in the talus areas of minor streams.

The whole basin is one of the most ancient intensively irrigated and cultivated parts of Afghanistan. Much of the cultivated land belongs to large landowners who do not work the land themselves, but rent it in small plots to peasants, on a sharecropping basis. According to official taxation figures, the bulk of the peasantry have on the average little more than one hectare of land per family. Peasants form about $85 \%$ of the total number of landowners, but own only about $25 \%$ of the privately cultivated lands. Such peasant ownership or operation of land in small scattered plots, and the poverty of the bulk of the peasantry, preclude the use of tractors and other modern agricultural machinery. Almost all the field work is done by draft animals or by hand.

Where water is suffioient, the lands are intensively used, but where it is in short supply, the peasants are forced to practise the crop-fallow system of rotation. The irrigated plots, as a rule, are very small, only rarely as large as $0.8-1.0$ hectare, but very well levelled. In most cases, they are watered by flooding; furrow irrigation is very rare.

The field crops grown include wheat, barley, millet, maize, pulses, oil plants, alfalfa, Persian clover, hemp, tobacco and melons, with orchards of cherries, almonds, aprioots, apples, pears, plums, grapes and mulberries. Vegetable crops are usually grown near the villages, in plots fenced off by mud walls, though sometimes in the fields, in rotation with nain crops. The vegetables too are very varied, including egs plants, turnips, radishes, ontons, garlic, carrots, spinach and cucumbers, as well as herbs and medicinal plants. Altogether, over 100 varieties of plants are cultivated in the Kabul basin. 
There are no strictly established systems of crop rotation, the peasants following rules based on age-long experienoe. In the intensively oultivated parts of the area, wheat, barley, alfalfa and Persian clover are sown in the autumn; peas, lobia, chick peas, rice, cotton, melons, hemp, corn, pumpkin, tobacco, vegetables- in the spring or early summer; sowing still continues into June. Rice is sown not later than May. Alfalfa is a perennial crop grown for several years at a time.

On the irrigated lands the main crops are wheat, rice, maize, and pulses. Alfalfa, Persian olover, barley, cotton, melons occupy about une third of the cropped area.

Artificial fertilizers are hardly used on the peasants' fields, but earth and organic manures are applied on a fairly large soale to the intensively oultivated lands. Earth manure, mixed with dung, is applied before ploughing in quantities of 40-50 $\mathrm{m}^{3}$ per hectare, thus gradually increasing the thickness of the top soil.

Control of pests and diseases of field crops, fruit trees and bushes is carried out, but very ineffectively, as the materials and equipment necessary for this purpose, are very limited and concentrated on a few state agrotechnical stations of the Ministry of Agriculture, which cannot yet carry out activities of this kind on a large scale.

Irrigation is mainly done by using the natural regime of the surface flows of the Kabul river and its tributaries; only an insignificant part of the lands in the wider valleys are irrigated through "Karezes".

The lands in the upper reaches of the survejed rivers were not studied, but all the available areas there are intensively cultivated.

The 172,400 hectares of Class II and III lands are fit for irrigated agriculture. Of this, only 98,200 hectares are now supplied with water and intensively cultivated each year; the other 74,150 hectares of irrigable lands cannot be fully used for farming purposes due to the present lack of water. Out of these lands, about 50\% are annually used for dry farming crops, watered, at most, during the winter and early spring. While spending much effort on these lands, the peasant obtains very low harvests from them. These figures show the extent to which suitable lands are available for development, but are now not fully used because of lack of water. 


\section{CEAPTER 21 - HYDROLOGI}

1. Initial Data. Regular hydrological observations and measurements in the Kabul basin were started in 1959 by the German hydrologioal group working under the Ministry of Mines and Industries of Afghanistan. This Group set up in the Kabul basin 16 gauging stations, of which 15 were equipped with water level recorders: 5 on the Kabul river, 2 on the Logar river, and the remaining 9 on the Ghorband, Panjshir, Kunar and Paghman rivers. A further gauging station was set up on the Logar river, near the proposed storage damsite at Kajao, by the hydrologists of the Project. Several hydrological surveys have been carried out in the Kabul basin by special missions. In 1957, a Soviet mission conducted extensive investigations on the Kabul river at Naghlu, and on some of the tributaries.

In appraising the Kabul water resources, the following initial data were used as the basis for the computation of various hydrological characteristics of the Kabul rivers, particularly at the proposed storage damsites.

a) Water discharges in the years 1960 to 1962 at the German-installed gauging stations;

b) Daily water discharges of the Logar river at the Kajao gauging station for March-July 1963.

These data are appended to Volume III - Hydrology.

2. Regime of the Kabul river system. Like most of the rivers of Afghanistan, the Kabul river has a regime which is mainly determined by the climatic peculiarities and the terrain of its basin.

The watersheds of the tributaries from the right-bank of the Kabul river are considerably lower than those of the left-bank tributaries. This considerably influences the distribution and amounts of precipitation. In the alpine zones of the Hindu Kush, on the left-bank, precipitations are twice to three times those occurring on the slopes of the mountain ridges which confine the basin to the south and west. In the part of the basin, on the right bank much of the precipitation falls as rain; in its left-bank part in the shape of snow. This peculiarity is reflected in the form, height and timing of the flood wave.

In respect of its water regime, the Kabul river system, within Afghanistan, can be divided into three reaches: 1) From the headwaters down to the confluence with the Panjshir; 2) From the mouth of the Panjshir down to the confluence with the Kunar river; 3) From the mouth of the Kunar down to the border of Pakistan.

(i) First Reach. The water flows here are small as compared with those in the others. Here the main contribution to run-off comes from rain. As a rule, the flood here starts in Maroh and ends in a low year in May, and in a high year in June-July.

Usually, the maximum discharges occur in April, and they vary quite a lot from year to year. Thus, for example, in 1960 which was a high year, the maximum discharge at Tangi-Gharu was $175 \mathrm{~m}^{3} / \mathrm{sec}$., whereas in 1962 , a low year, it was a mere $35 \mathrm{~m} 3 / \mathrm{sec}$. 
In the summer low water period, almost all the water is taken up for irrigation. At the Tangi-Gharu station in August-September the discharges do not exoeed 100-200 1/8e0.

(ii) Second Reach. The regime here is quite different from that in the first reach. Tho najor tributaries, the Panjahir and the Aliahang, contribute much water to the river; snow-melt waters play the main part in their runoffs. Here, therefore, the flood period is more prolonged; it lasts 4 to $5 \frac{1}{2}$ months at the Naghlu and Darunta gauging stations.

The maximum mean monthly runoff in this stretch is observed usually in June and, less often, in April-May. At Darunta, the maximum water discharge observed over a 3 -year period, reached in the comparatively high year of 1960 , was $1560 \mathrm{~m} / \mathrm{sec}$, that is, nine times more than in the first reach at Tangi-Charu, only $70 \mathrm{~km}$ upstream. The maximum difocharge here at the same station in the low year of 1962 was $900 \mathrm{~m}^{3} / \mathrm{sec}$, which was 25 times more than that at Tangi Gharu.

Though within this reach also much water is taken off for irrigation, the minimum water discharges observed at Darunta have not been less than $35-40 \mathrm{~m}^{3} / \mathrm{sec}$.

(iii) Third Reach. This carries considerably more water than the second, as it is also fed by the Kunar tributary, which has more water than any other. In the run-off of the Kunar, the largest contributions come from the snowmelt waters of the current year, plus those derived from the Hindu Kush glaciers; the duration of the Kabul flood below the Kunar confluence extends up to 7-8 months.

The maximum water discharges occur, as a rule, in July, and the minimum discharges in February. The maximum discharges here are almost twice those in the second stretch. In 1960, below the Kunar river, the maximum discharge was $3,000 \mathrm{~m} 3 / \mathrm{sec}$, whereas at Darunta it was $1560 \mathrm{~m} / \mathrm{sec}$.

3. Normal Annual Runoff. The method used in calculating the normal annual runoffs for different damsites on the Kabul rivers is given in Volume III - Hydrology; this Chapter gives only a summary of the resulting figures. Average annual runoffs are given in Table 56 below:-

\section{TABLE 56}

KABUL BASIN - AVERAGE ANNUAL RUNOFFS AT VARIOUS SITES

\begin{tabular}{|c|c|c|c|c|c|}
\hline Place & $\begin{array}{l} \\
! \\
1\end{array}$ & of River & $\begin{array}{l}T \\
1 \\
\end{array}$ & $\begin{array}{c}\text { Normal Annual } \\
\text { Discharge } \\
\left(\mathrm{m}^{3} / \mathrm{sec} .\right)^{-}\end{array}$ & $\begin{array}{lc}! & \text { Normal Annual } \\
! & \text { Runoff } \\
! & \left(\mathrm{km}^{3}\right) \\
\end{array}$ \\
\hline $\begin{array}{l}\text { 1. Tangl Saidan } \\
\text { 2. Tangi Charu } \\
\text { 3. Naghl } \\
\text { 4. Kajao } \\
\text { 5. Nawishta } \\
\text { 6. Pul-i-Ashawa } \\
\text { 7. Gulbahar }\end{array}$ & $\begin{array}{l}\text { Kabul } \\
\text { Kabul } \\
\text { Kabul } \\
\text { Logar } \\
\text { Logar } \\
\text { Chorband } \\
\text { Panjahir }\end{array}$ & & & $\begin{array}{r}6.0 \\
22.6 \\
142.0 \\
10.5 \\
18.2 \\
27.0 \\
62.5\end{array}$ & $\begin{array}{l}0.19 \\
0.71 \\
4.47 \\
0.33 \\
0.57 \\
0.85 \\
1.97\end{array}$ \\
\hline
\end{tabular}


4. Fluctuations of Anmual Runoff. The hydrologists determined the parameters of the probability curve, with the help of which values were estimated for annual runoffs of various probabilities. These are given in Table 57.

TABLE. 57

KABUL BASIN - ESTIMATED MEAN ANNUAL DISCHARGES OF VARIOUS PROBABIILITIES *

\begin{tabular}{|c|c|c|c|c|c|c|c|c|c|c|}
\hline \multirow[b]{2}{*}{ Damsites } & \multicolumn{6}{|c|}{ Estinated Mean Annual Water Discharges } & \multicolumn{4}{|c|}{$\left(\mathrm{m}^{3} / \mathrm{sec}\right)$ at $\%$ Probability } \\
\hline & & 3 & 5 & 10 & 120 & $! 50$ & $! 75$ & $! 95$ & $! 97$ & 99 \\
\hline $\begin{array}{l}\text { Tangi Saidan } \\
\text { Tangi-Gharu } \\
\text { Naghlu } \\
\text { Ka jao } \\
\text { Nawishta } \\
\text { Pul-i-Ashawa } \\
\text { Gulbahar }\end{array}$ & $\begin{array}{l}14.0 \\
50.5 \\
307 \\
22.6 \\
42.5 \\
57.2 \\
124\end{array}$ & $\begin{array}{l}12.0 \\
45.2 \\
266 \\
19.6 \\
36.4 \\
50.5 \\
109\end{array}$ & $\begin{array}{l}11.0 \\
41.6 \\
247 \\
18.3 \\
33.5 \\
47.0 \\
102\end{array}$ & $\begin{array}{l}9.6 \\
36.2 \\
218 \\
16.2 \\
29.1 \\
41.5 \\
92.0\end{array}$ & $\begin{array}{l}8.1 \\
30.3 \\
186 \\
13.8 \\
24.5 \\
35.3 \\
80.0\end{array}$ & $\begin{array}{l}5.6 \\
21.1 \\
140 \\
10.0 \\
17.0 \\
25.6 \\
60.0\end{array}$ & $\begin{array}{r}4.0 \\
15.2 \\
104 \\
7.4 \\
12.2 \\
19.2 \\
47.0\end{array}$ & $\begin{array}{r}2.4 \\
9.1 \\
64.0 \\
4.7 \\
7.3 \\
12.2 \\
31.8\end{array}$ & $\begin{array}{r}2.0 \\
7.7 \\
55.4 \\
4.1 \\
6.2 \\
10.5 \\
28.0\end{array}$ & $\begin{array}{r}1.6 \\
5.9 \\
43.1 \\
3.2 \\
4.8 \\
8.4 \\
23.1\end{array}$ \\
\hline
\end{tabular}

5. Run-off distribution within the year. Not only is the run-off unevenly distributed within the year, the greater part coming during the flood period, but the distributions in the upper and lower reaches are far from similar. In the upper reaches the flood lasts 2-4 months, while on the lower Kabul it may last 6-7 months or, below the confluence of the Kunar river, even longer.

\section{TABLE 58}

KABUL BASIN - MONTHLY DISTRIBUTIONS OF ANNUAL FLOWS

Type of Year $\begin{aligned} & \text { Runoff Distribution in }{ }^{30} \text { within the Year } \\ & \end{aligned}$

Kabul river at Tangi Saidan

$\begin{array}{lllrlllllllllll}\text { Mean Year } & 10.1 & 9.0 & 10.1 & 24.0 & 15.0 & 3.2 & 1.8 & 1.5 & 3.0 & 5.1 & 8.5 & 8.7 & 100 & 6.0 \\ \text { Low 1962 year } & 10.0 & 7.9 & 8.3 & 25.2 & 13.0 & 4.3 & 3.2 & 3.2 & 3.7 & 4.5 & 7.6 & 9.1 & 100 & 3.8\end{array}$

Logar river at Kadjao si te

$\begin{array}{lllllllllllllll}\text { Mean Year } \quad 10.1 & 9.0 & 10.1 & 24.0 & 15.0 & 3.2 & 1.8 & 1.5 & 3.0 & 5.1 & 8.5 & 8.7 & 100 & 10.5\end{array}$

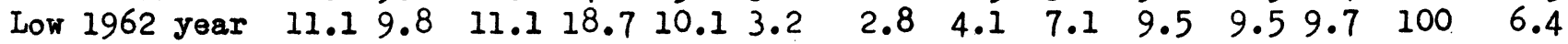

Ghorband river at Pul-i-Ashawa

$\begin{array}{lrrrrrrrrrrrrrrr}\text { Mean Year } & 3.9 & 4.0 & 5.8 & 11.7 & 19.0 & 21.6 & 11.8 & 5.2 & 4.2 & 3.8 & 4.7 & 4.3 & 100 & 27.0 \\ \text { High 1960 year } & 1.6 & 3.4 & 7.5 & 11.2 & 20.6 & 22.3 & 14.8 & 5.8 & 3.5 & 2.7 & 3.5 & 3.1 & 100 & 38.7 \\ \text { Low } 1962 \text { year } & 5.1 & 5.0 & 5.6 & 11.8 & 16.1 & 19.4 & 9.5 & 4.9 & 5.6 & 5.4 & 6.0 & 5.6 & 100 & 20.9\end{array}$

Panjshir river at Culbahar site

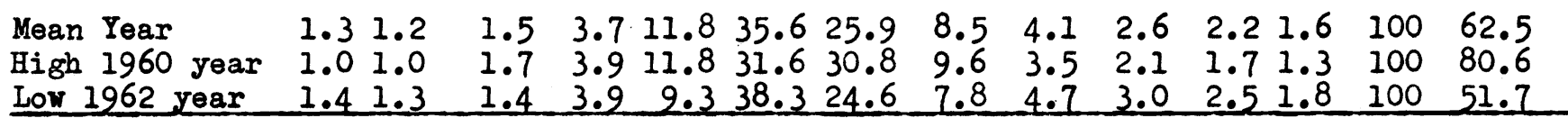


It is notable that for all the gauging stations on the Kabul river and its tributaries, in years that differ in their total runoff, the percentage distributions within the year vary also. For instance, in a low year, the percentage of the annual runoff increases in the low water autumn-winter period and decreases in the flood period. In a high year, the converse occurs.

6. Maximum Discharges. Estimates were made of the maximum water discharges at various probabilities, without and with margins for exceptional conditions. Table 59 gives the figures, including those sites which are proposed for the construction of reservoirs.

TABLE 59

KABUL BASIN - ESTIMATED MAXIMUM RIVER DISCHARGES OF VARIOUS PROBABILITIES (m $3 / \mathrm{sec}$ )

\begin{tabular}{|c|c|c|c|c|c|c|c|c|}
\hline Name of site ! & Discharge! & & rim & in $\mathrm{Dis}$ & ges (m3 & at \% F & $i$ & $i t y$ \\
\hline and river ! & Regime ! & $0.1 \%$ & $!$ & $1 \%$ & $3 \%$ & $5 \%$ & $!$ & $10 \%$ \\
\hline $\begin{array}{l}\text { Tangi Saidan, } \\
\text { on Kabul river }\end{array}$ & $\begin{array}{l}\text { Normal } \\
\text { Exceptional }\end{array}$ & $\begin{array}{l}215 \\
260\end{array}$ & & $\begin{array}{l}140 \\
170\end{array}$ & 110 & 95 & & 75 \\
\hline $\begin{array}{l}\text { Kajao, on } \\
\text { Logar river }\end{array}$ & $\begin{array}{l}\text { Normal } \\
\text { Exceptional }\end{array}$ & $\begin{array}{l}325 \\
390\end{array}$ & & $\begin{array}{l}210 \\
250\end{array}$ & 160 & 140 & & 110 \\
\hline $\begin{array}{l}\text { Pul-i-Ashawa, } \\
\text { on Ghorband } \\
\text { river }\end{array}$ & $\begin{array}{l}\text { Normal } \\
\text { Exceptional }\end{array}$ & $\begin{array}{l}465 \\
560\end{array}$ & & $\begin{array}{l}350 \\
420\end{array}$ & 295 & 265 & & 225 \\
\hline $\begin{array}{l}\text { Culbahar, } \\
\text { on Panjshir }\end{array}$ & $\begin{array}{l}\text { Normal } \\
\text { Exceptional }\end{array}$ & $\begin{array}{l}1630 \\
1960 \\
\end{array}$ & & $\begin{array}{l}1260 \\
1510 \\
\end{array}$ & 1060 & 970 & & 840 \\
\hline
\end{tabular}

Note: 1) Because of the short series of observations of maximum discharges, a margin of safety for exceptional conditions for the maximum discharges was taken at $20 \%$ above the normal figure.

7. Minimum Discharges.

TABLE 60

KABUL BASIN - ESTIMATED MINIMUM RIVER DISCHARGES OF VARIOUS PROBABIIITIES

\begin{tabular}{|c|c|c|c|c|c|c|c|c|c|c|}
\hline & Mear & Mont & $21 \mathrm{y} \mathrm{Min}$ & imum Wat & I Disoh & harges & $(\mathrm{m} 3 / \mathrm{sec})$ & at $\%$ & Probabil & $i t y$ \\
\hline Name of Site & $1 \%$ & $3 \%$ & $5 \%$ & $110 \%$ & $20 \% !$ & $150 \%$ & $975 \%$ & $95 \%$ & $! 97 \% !$ & $99 \%$ \\
\hline $\begin{array}{l}\text { Tangi Saidan } \\
\text { Kajao } \\
\text { Pul-i-Ashawa } \\
\text { Culbahar }\end{array}$ & $\begin{array}{r}4.7 \\
6.0 \\
24.0 \\
22.8\end{array}$ & $\begin{array}{r}4.0 \\
5.2 \\
21.0 \\
20.5\end{array}$ & $\begin{array}{r}3.7 \\
4.9 \\
19.6 \\
19.3\end{array}$ & $\begin{array}{r}3.2 \\
4.4 \\
17.6 \\
17.5 \\
\end{array}$ & $\begin{array}{r}2.7 \\
3.8 \\
15.4 \\
15.5\end{array}$ & $\begin{array}{r}1.9 \\
2.9 \\
11.5 \\
12.2\end{array}$ & $\begin{array}{l}1.3 \\
2.2 \\
9.0 \\
9.7\end{array}$ & $\begin{array}{l}0.8 \\
1.5 \\
6.1 \\
7.0\end{array}$ & $\begin{array}{l}0.68 \\
1.35 \\
5.4 \\
6.5 \\
\end{array}$ & $\begin{array}{l}0.52 \\
1.10 \\
4.5 \\
5.4\end{array}$ \\
\hline
\end{tabular}

On the Kabul river and its tributaries the minimum runoffs observed are much affected by the large abstractions of water for irrigation, and therefore Table 60 does not exactly reflect the actual runoff values. However, these data can be used for purposes of preliminary appraisal. 
8. Sediment Disoharge. In the Kabul basin, catchment slopes are steep, regetation cover is scanty, and there is much debris. When surface run-off oocurs, these factors contribute to an intensive erosion of minor soil partioles from the slopes. As a result, during the flood high silt loads occur on the rivers, sometimes reaching several kilogrammes per $\mathrm{m}^{3}$ of water. There is, however, little or no sediment discharge during the low water period.

From the data of silt charges and normal annual runoffs given in Volume III, calculations have been made of the normal anmual silt discharges in the Kabul and its tributaries.

\section{TABLE 61}

KABUL BASIN - SEDIMEANT DISCHARGES AT VARIOUS SITES

\begin{tabular}{|c|c|c|c|c|c|c|}
\hline \multirow[t]{2}{*}{ Place } & \multirow{2}{*}{$\begin{array}{ll}! & \\
! & \text { Suspended } \\
! & \text { silt } \\
! & \text { mill.tons } \\
\end{array}$} & \multicolumn{2}{|c|}{$\begin{array}{c}\text { Total } \\
\text { Annual Sediment } \\
\text { discharge }\end{array}$} & \multirow{2}{*}{$\begin{array}{cc}! & \\
! & \text { Basin } \\
! & \text { area } \\
! & \left(\mathrm{km}^{2}\right)\end{array}$} & \multirow{2}{*}{$\begin{array}{l}\text { Sediment } \\
1 \text { discharge } \\
1 \text { per } \mathrm{km}^{2} \text { of } \\
1 \text { catchment } \\
! \text { (tons) } \\
\end{array}$} & \multirow{2}{*}{$\begin{array}{l}\text { Ratio of } \\
\text { sediment } \\
\text { to liquid } \\
\text { munoff }(\%)\end{array}$} \\
\hline & & $i$ mill.tons & $\mathrm{mill} \cdot \mathrm{m}^{3}$ & & & \\
\hline $\begin{array}{l}\text { Tangi Saidan } \\
\text { Kajao } \\
\text { Pul-i-Ashawa } \\
\text { Culbahar } \\
\text { Naghlu }\end{array}$ & $\begin{array}{r}0.48 \\
0.83 \\
1.70 \\
3.94 \\
11.20 \\
\end{array}$ & $\begin{array}{r}0.53 \\
0.91 \\
1.87 \\
4.23 \\
12.30 \\
\end{array}$ & $\begin{array}{l}0.41 \\
0.70 \\
1.44 \\
3.26 \\
9.50 \\
\end{array}$ & $\begin{array}{r}1900 \\
4720 \\
4440 \\
5610 \\
30010 \\
\end{array}$ & $\begin{array}{l}280 \\
190 \\
420 \\
750 \\
410 \\
\end{array}$ & $\begin{array}{l}0.22 \\
0.21 \\
0.17 \\
0.17 \\
0.21 \\
\end{array}$ \\
\hline
\end{tabular}

Note: In determining the figures of sediment discharge, the bed load is taken at $10 \%$ of the suspended load.

To give an idea of the composition sediment texture, Table 62 gives data for the Naghlu station on the Kabul river.

\section{TABLE 62}

KABUL RIVER - PERCENTAGE COMPOSITION OF SEDIMFNTS

Dimensions of particles in millimetres

\begin{tabular}{llllllll}
\hline 1.0 & $! 1.0-0.25$ & $! 0.25-0.1$ & $0.1-0.05$ & $0.05-0.01 !$ & $0.01-0.005 !$ & 0.005 \\
\hline $0.0 \%$ & $21.2 \%$ & $15.8 \%$ & $18.3 \%$ & $14.3 \%$ & $18.2 \%$ & $12.2 \%$ \\
\hline
\end{tabular}

It is necessary to point out that the data on sediment discharge and the composition of the sediments are approximate, and must be subject to further investigation by systematic studies at each gauging station for a number of years. 
1. General Information. In the Kabul basin seven potential sites for dams were found, and studied in various degrees. One of these was on the Panjahir, four werv on the Ghorband, one on the Logar and one on the Bala Maidan (the Opper Kabul river).

In accordance with the preliminary scheme of irrigation development for the Kabul basin, discussed in Chapter 23, additional irrigation of lands from the Logar and Kabul (Bala Maidan) rivers is planned with regulation of their run-offs, whereas water from the Ghorband and Panjahir river will be drawn from their uncontrolled flows. It should be emphasized that this is a preliminary conclusion at the present stage of the project, and is subject to review after detailed topomaps for the irrigable areas become available.

Accordingly, only two reservoirs are at present contemplated for the Kabul basin: at Tangi Saidan on the Bala Maidan, and at Kajao on the Logar river. (See map No. 14)

The geological description of these damsites is given in Volume II, and their use for water control is discussed in Volume $\nabla$.

Some main features of the suggested reservoirs are given in Table 63.

TABLE 63

KABUL BASIN - MAIN FEATURES OF TANGI SAIDAN AND KAJAO RESERVOIRS

\begin{tabular}{|c|c|c|c|c|c|c|c|}
\hline $\begin{array}{l}\text { Name of } \\
\text { Reservoir }\end{array}$ & $\begin{array}{l}! \\
! \text { Name of } \\
\text { ! River } \\
! \\
\vdots \\
! \\
\end{array}$ & $\begin{array}{ll} & \\
! & \text { Maximum } \\
! & \text { head } \\
! & (\mathrm{m}) \\
! & \\
! & \\
\end{array}$ & $\begin{array}{l}\text { ! Full cap-! } \\
\text { ! acity of ! } \\
\text { !reservoir! } \\
\text { !at maxim-! } \\
\text { ! um head ! } \\
\text { ! mill.ou.! } \\
\text { ! m })\end{array}$ & $\begin{array}{l}\text { Mean run! } \\
\text { off at } \\
\text { damsite } \\
\text { (mill.m } 3) ! \\
! \\
! \\
!\end{array}$ & 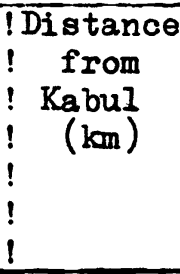 & $\begin{array}{l}\text { ! Net } \\
\text { ! Available } \\
\text { !storage } \\
!(\text { mill.cu. } \\
(\mathrm{m}) \\
!\end{array}$ & $\begin{array}{l}\text { Water } \\
\text { ! Control } \\
\text { ! Coeffic- } \\
\text { !ient } \\
!(7: 5) \\
! \\
!\end{array}$ \\
\hline 1 & 2 & 3 & 4 & 5 & 6 & 7 & 8 \\
\hline $\begin{array}{l}\text { Tangi Saldan } \\
\text { Kajao }\end{array}$ & $\begin{array}{l}\text { Kabul } \\
\text { Logar }\end{array}$ & $\begin{array}{r}64 \\
101\end{array}$ & $\begin{array}{l}110 \\
360\end{array}$ & $\begin{array}{l}189 \\
315\end{array}$ & $\begin{array}{r}18 \\
137\end{array}$ & $\begin{array}{r}69 \\
290\end{array}$ & $\begin{array}{l}0.36 \\
0.92\end{array}$ \\
\hline
\end{tabular}

When choosing the dam types, in each case account was taken of the geological conditions of the site, and of the availability of local building materials, and the minimum possible use of cement, timber and metal.

Proceeding from these considerations, the types of dam adopted and worked out were (a) a rookfill dam with a reinforced concrete facing for the Tangi-Saidan site, and (b) a concrete gravity dam for the Kajao site.

2. Water Control and Water Balance Calculations. The preliminary scheme of irrigetion development for the valleys of the Kabul and Logar, described in Chapter 23, calls for the increase of the present irrigated area of 27,500 hectares up to 43,500 hectares.

As already shown in Chapter 21 , almost $50 \%$ of the annual flow of the two rivers comes down in the three months March to May, whereas the irrigation requirement during the same time comes to little more than $21 \%$ of the same total. 
In these circumstances, the further development of irrigated agriculture in these valleys is possible only if most of the spring flood run-offs are controlled.

Computations of the regulation of the upper Kabul river by Tangi Saidan reservoir, to irrigate 10,500 hectares, and of the Logar river by Kajao reservoir to irrigate 33,000 hectares, have been made for monthly periods in years of $75 \%$, $50 \%$, and 20\% probability. Fall particulars of these are given in Vol. V. They lead to the following conclusions:-

(i) In a low year of $75 \%$ probability, the net available capacity in Tangi Saidan reservoir will be fully used in providing merely seasonal storage.

(ii) The muoh larger net capacity in Kajao reservoir will suffice not only for seasonal storage, but also to provide overyear storage. In a high year of $20 \%$ probability, it will be filled to its maximum, after being lowered to its minimum in previous low years.

(iii) Surplus water in excess of irrigation requirements will have to be spilt from Tangl Saidan reservoir in almost all years, and from Kajao reservoir in high years. The run-off controlled by the reservoirs, 189 mill. 3 at Tangi Saidan and $315 \mathrm{mill} \mathrm{m}^{3}$ at $\mathrm{Kajao,}$, will be about $70 \%$ of the average run-off of the Kabul river at Tangi Gharu ( $713 \mathrm{mill} . \mathrm{m} 3$ ), below the confluence of the Bala Maidan and the Logar. To make a better use of the water resources and to develop further the irrigated area in the upper Kabul basin, more storage oapacity is wanted. At the next stage of investigation, the possibilities of other reservoir sites should be examined, on the Logar river downstream of $\mathrm{KajaO}$, and the Bala Maidan upstream of Tangl Saidan.

It should be noted that the runoff control calculations for the Logar river were made for Kajao, whereas the water balance estimates for the Logar irrigation soheme were made for the Nawishta gauging station below which there are situated lands to be irrigated. Consequently, the water balance estimates take into account the local inflows from the catchment area situated between Kajao and Nawishta.

\section{Reservoir Worke.}

a) Tangi Saidan Dam. Because of the existence of a saddle in the ridge forming the right hand side of the reservoir, it was established that the optimum height for the Tangi Saidan dam is about $52 \mathrm{~m}$, corresponding to a gross capacity of $110 \mathrm{mill} . \mathrm{m}^{3}$. The mean annual sediment discharge at this point comes to $0.41 \mathrm{mill}$. $\mathrm{m}^{3}$, or $41 \mathrm{mill}$. $\mathrm{m}^{3}$ for a hundred yearg. The net available storage of the reservoir will thus be equal to 69 mill. m3.

The existence of a fault in the river bed is a main reason for adopting as the dam type a rookfill dam with a ferro-concrete facing. The works at Tangl Saidan will include the following:

1) A rockfill dam with a reinforced concrete facing. For a better junction the facing with the river bed and banks, as well as to prevent infiltration under the dam, there is provision for a cut-off to a depth of $20 \mathrm{~m}$, and below it a grouted zone to a depth of $30 \mathrm{~m}$.

2) A diversion tunnel with upstream and downstream cofferdams, to pass an estimated discharge of $95 \mathrm{~m} 3 / \mathrm{sec}$ at $5 \%$ probability.

3) An emergenoy spillway of trough type, leading to shaft joing the diveraion tunnel. The estimated spillway discharge is taken equal to $170 \mathrm{~m} 3 / \mathrm{sec}$, which corresponds to a $1 \%$ probability, in exceptional conditions.

4) An outlet for irrigation water. As about $80 \%$ of the prospective irrigable areas are concentrated on the left bank, it appears preferable to have one intake on the left bank, and thence to take water to the right bank through a reinforced-concrete pipe placed on a berm of the downstream slope. 
5) A rockfill levee with a reinforced concrete facing, to close the saddle on the right side of the reservoir.

Details of these proposed works are shown on Drawing No. 25 attaohed By the construction of the Tangi Saidan reservoir, there will be flooded about 300 hectares of irrigated lands and up to 80 farmsteads.

b) Kajao Dam The geological conditions described in Chapter 27 of Volume II Indicate that the river fault has shifted the quartzite so as to make a relatively small net width capable of acting as a foundation to a concrete dam. There is uncertainty about the depth of the river gravels and the nature of the conoealed river fault. It is probable that both a rookfill and a concrete gravity structure could be construoted in this gorge, but for the purpose of preliminary study only a concrete gravity dam is essumed. The design of the works includes the following items:-

1) A conorete gravity dam, in the centre of which is formed the spillway. The maximum construction height of the dam is $104 \mathrm{~m}$., and its length along the crest is about $300 \mathrm{~m}$. The gross reservoir capacity is 360 mill.m 3 , $\rho^{f}$ which dead storage for siltation over 100 years requires 70 mill.m 3 , leaving a net effective capacity of $290 \mathrm{mill} . \mathrm{m}^{3}$.

2) An emergency spillway for a disoharge of $250 \mathrm{~m} /$ sec. ( $1 \%$ probability), consisting of two openings each $7 \mathrm{~m}$. wide and $4.24 \mathrm{~m}$. high fitted wi th segment gates.

3) A diversion tunnel to pass a discharge of $140 \mathrm{~m}^{3} / \mathrm{sec}$. at $5 \%$ probability, with 2 construction cofferdams of shingle and gravel, taken from the river bottom plain.

4) An outlet for Irrigation water, incorporated in the dam body, has two openings each $2 \mathrm{~m}$. wide. Details of the works are shown on Drawing No. 26 attached.

The area to be flooded by the reservoir will cover about 500 heotares of irrigated land, 400 houses and a $13 \mathrm{Km}$. stretch of a dirt motorable road.

4. Quantities of Work and Costs Table 64 below gives the main quantities of work for the construction of the Tangi Saidan and Kajao dams and their estimated costs in US \$.

\section{TABLE 64}

TANGI SAIDAN AND KAJAO DAMS - QUANTITIES AND COSTS OP WORKS

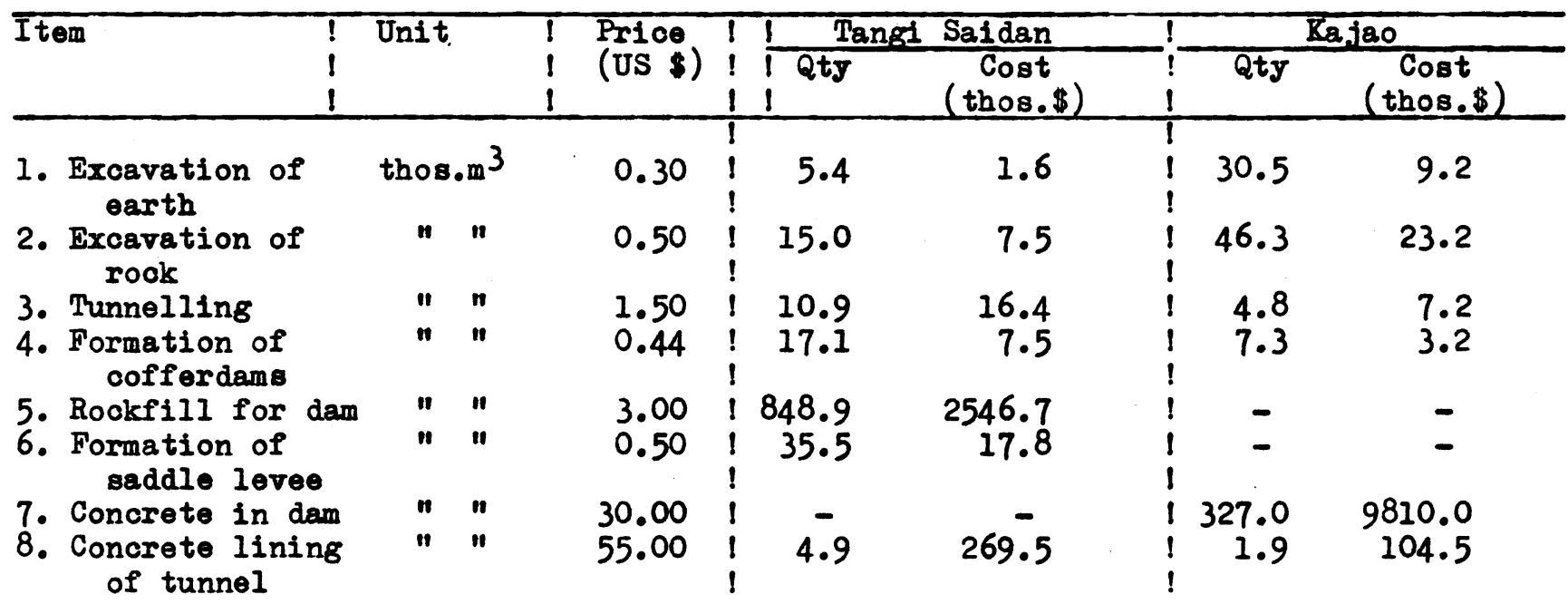


TABLE 64 (cont'd)

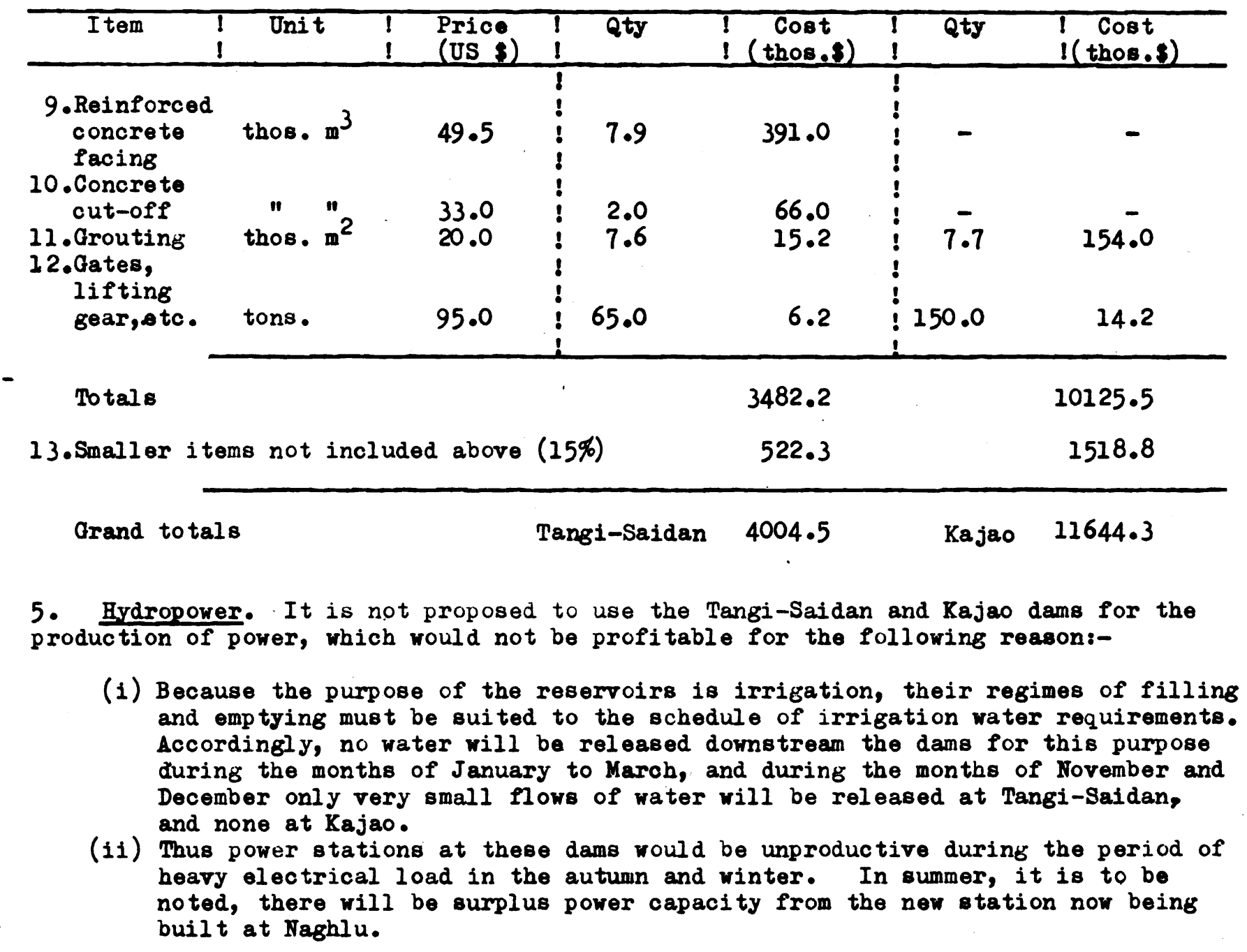

6. Specific Indices of Reservoirs, On the preliminary designs and estimates, the specific costs of the two reservoirs are as shown in Table 65.

\section{TABLE 65}

TANGI-SAIDAN AND KAJAO RESERVOIRS - SPECIFIC COSTS

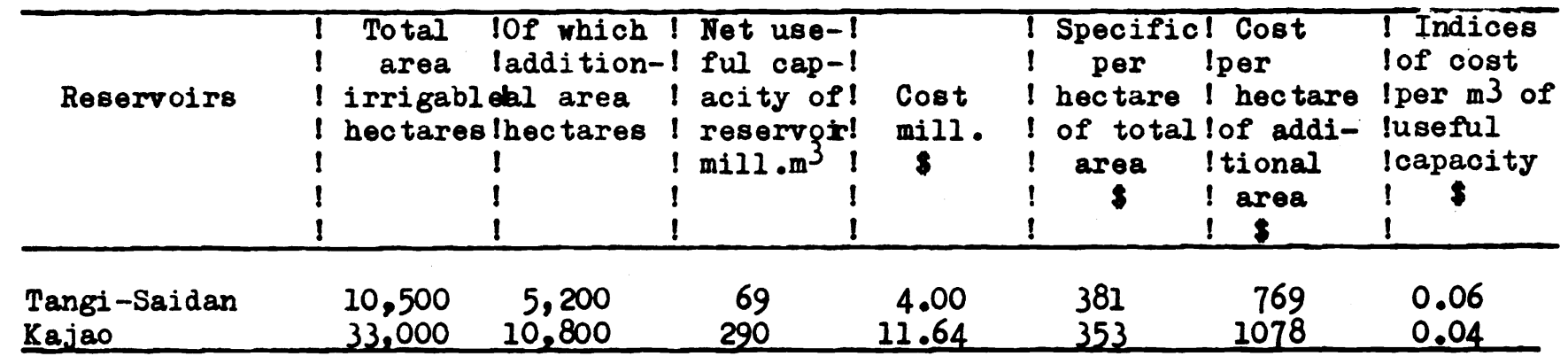


These specifio indices of cost are somewhat high, but there can ke little doubt as to the economic justification of the reservoir proposals. Bowever, before final decisions are taken, this question should be further examined, after more detailed technical and economic investigations have been made. 
1. General Information. Soll surveys have established that in the upper Kabul basin, down to Sarobi, there are some 70,000 hectares of unused land suitable for irrigation development. Unused water resources could also be made available after reconstruction of the heedworks and main canals of the existing irrigation systems, together with water control on some of the Kabul river tributaries.

However, due to the lack of topographical maps of this part of the basin, it is impossible jet to provide a detalled scheme for the development of irrigation. This problem can be fully solved only when the Government of Afghanistan receives the topographical maps, at a soale of 1:50.000, which are now being prepared in the USA.

In these circumstances, an outline scheme for irrigation development within the surveyed parts of the area has been prepared, based mainly on visual reconnaissance by hydraulic engineers, with some very scanty preliminary information about the elevations of the land and the sources of irrigation. This is discussed in Vol. VI.

It was decided, for convenience, to prepare this scheme in two independent parts. The first part covers the resouroes of the Shakar Dara, Ghorband and Panjahir rivers, and is called "The Shakar Dara Valley Scheme". This provides for irrigation development without the construction of any reservoirs. The second part combines the resources of the Bala Maidan (Upper Kabul) and Logar, and is called MThe Kabul Valley Scheme". This scheme provides for irrigation development with water control of these rivers by the construction of two reservoirs, as discussed in Chapter 22.

\section{SHAKAR DARA VALLEY}

2. Scheme of Irrigation Development. Of the total area of some 98,000 hectares of land covered by soil surveys in this region, lands in Classes II and III total 75,700 hectares gross, or some 67,000 hectares net irrigable area, assuming a landuse coefficient of 0.88 . The areas under command from the different sources of water supply are estimated to be approximately as follows:-

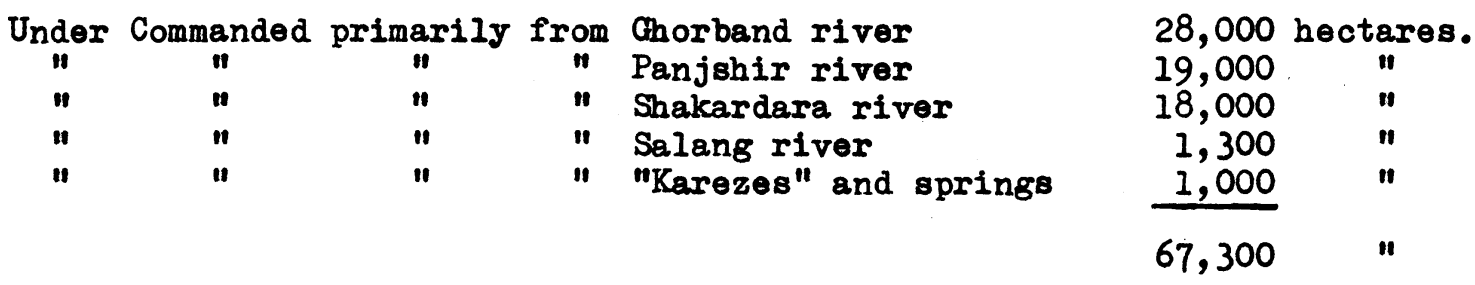

Estimations of the natural flows of the Chorband and Panjshir rivers in a year of $75 \%$ probability show that even without any water control by storage reservoirs, the flows would suffice for the irrigation of some 15,700 hectares from the Chorband, and over 44,000 hectares from the Panjshir. (Similar estimations for the Shakardara and Salang rivers are not at present available.) Clearly on the Chorband there is more suitable land that can be irrigated, while on the Panjshir there is a surplus of water.

After consideration of the circumstances the potential development forecast is as shown in Table 66. 
TABL. 66

SHAKARDARA VALLEY - ARFAS IRRTGABLE FROM DIFFERENT SOURCES

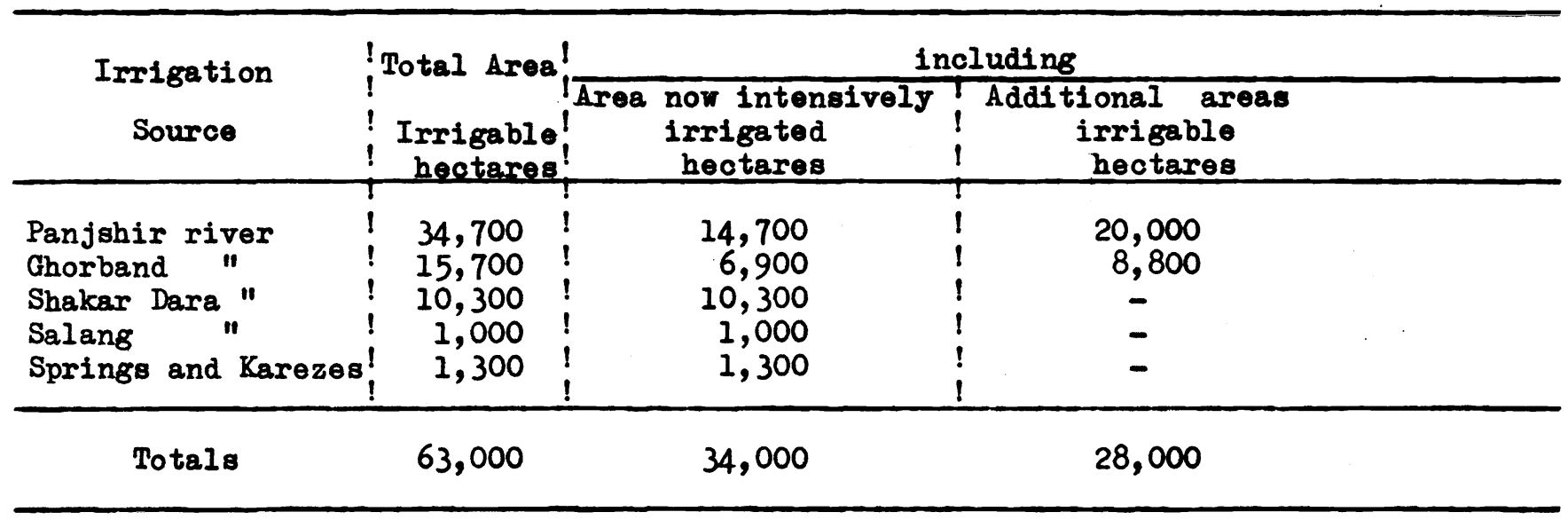

In the absence of contour maps of the region, and in view of the complex nature of the terrain, 1t was only found possible to work out a preliminary soheme of irrigation development for the lands irrigable from the Panjshir and Chorband rivers, totalling 50,400 hectares as shown above. Development of the lands commanded from other sources, 12,600 hectares, is not proposed at present.

The soheme for the development of the 50,400 heotares allows for the use of surplus water from the Panjshir to irrigate lands on the Ghorband which cannot be supplied from that river. An outline of the scheme is as follows. Headworks of weir type are proposed on the Ghorband river 5 kiloms. upstream from the bridge on the Kabul-Salang road, and on the Panjahir river at Gulbahar. From the Ghorband headworks a right bank main canal will carry up to $26 \mathrm{~m} 3 / \mathrm{sec}$, for the irrigation of 15,700 hectares. From the headworks on the Panjehir river, there will be two main canals, on the right and left banks. The right-bank canal, with a capacity of $26 \mathrm{~m} 3 / \mathrm{sec}$, will irrigate 20,500 heotares. This canal will cross the Salang and Ghorband rivers by culvert syphons, at kilometres 10 and 15 of its length respectively. The left bank canal, with a capacity of $18 \mathrm{~m} 3 / \mathrm{sec}$, will irrigate 14,200 hectares.

3. Cropping Plans and Irrigation Regimes. The cropping plans for the lands irrigated from the Ghorband and the Panjshir are not the same. On the Ghorband, where water is limited, the proportions of crops which require much water are reduced; rice is excluded.

The overall rates of water requirement for the two areas are estimated as follows:-

a) Required for the irrigation of lands from the Ghorband river

MAIN CROPS

1. Wheat and barley

2. Cotton

3.Alfalfa

4. Vegetables and melons

5. Orchards and vineyards

6. Maize for corn

7.Pulses

$$
\begin{array}{rl}
33.0 \% \times 3,000 & =990 \mathrm{~m}^{3} \\
22.0 \% \times 8,000 & =1760 \mathrm{~m}^{3} \\
8.2 \% \times 8,200 & =672 \mathrm{~m}^{3} \\
5.5 \% \times 7,400 & =407 \mathrm{~m}^{3} \\
23.0 \% \times 6,200 & =1426 \mathrm{~m}^{3} \\
5.5 \% \times 4,300 & =236 \mathrm{~m}^{3} \\
2.8 \% \times 4,600 & =139 \mathrm{~m}^{3} \\
\hline 100 \% & 5630 \mathrm{~m}^{3}
\end{array}
$$$$
\text { Total }
$$ 
SECOND CROPS

8. Naize for silage

9.Vegetables

Total

$$
\begin{aligned}
& 22.0 \% \times 3,800=836 \mathrm{~m}^{3} \\
& 11.0 \% \times 3,800=418 \mathrm{~m}^{3} \\
& \hline 33.0 \%
\end{aligned}
$$

The average irrigation requirements (net) per hectare will thus come to $6884 \mathrm{~m}^{3}$ and, with the efficiency factor of the irrigation system taken as 0.60 , the average irrigation gross requirement at canal heads per hectare will be $-6884+0.60=$ $11,470 \mathrm{~m}^{3}$.

b) Required for the irrigation of land from the Panjshir river:

MAIN CROPS

1. Wheat and barley

2. Cotton

3.Alfalfa

4. Vegetables and melons

5. Orchards and vineyards

6. Rice

7.Maize for silage

8.Pulses

Total

SECOND CROPS

9. Maize for silage

10. Vegetables

Total

$$
\begin{array}{rl}
22.0 \% \times 3,000 & =660 \mathrm{~m}^{3} \\
33.0 \% \times 8,000 & =2640 \mathrm{~m}^{3} \\
8.2 \% \times 8,200 & =672 \mathrm{~m}^{3} \\
2.8 \% \times 7,400 & =207 \mathrm{~m}^{3} \\
17.5 \% \times 6,300 & =1065 \mathrm{~m}^{3} \\
11.0 \% \times 20,000 & =2200 \mathrm{~m}^{3} \\
2.7 \% \times 4,300 & =116 \mathrm{~m}^{3} \\
2.8 \% \times 4,600 & =139 \mathrm{~m}^{3} \\
100 \% & 7699 \mathrm{~m}^{3}
\end{array}
$$

$$
16.5 \% \times 3,800=627 \mathrm{~m}^{3}
$$$$
5.5 \% \times 3,800=209 \mathrm{~m}^{3}
$$

$22.0 \%$

$836 \mathrm{~m}^{3}$

The average net water requirement per hectare will thus be $8535 \mathrm{~m}^{3}$, and the gross requirement at canel heads per hectare will be $-8535+0.6=14,230 \mathrm{~m} 3$. (See also Drawing No. 3I)

4. Total requirement of irrigation water. In accordance with the gross irrigation requirements per hectare, as given above, the provision of a combined water supply from the Ghorband river for an area of 15,700 heotares and from the Panjehir river for an area of 34,700 hectares was worked out.

Table 67 shows the comparison of the runoffs of the Ghorband and Panjshir rivers in a year of $75 \%$ probability with the combined water requirements of irrigation from these rivers throughout the year.

\section{TABLE 67}

CHORBAND AND PANJSHIR RIVERS

COMPARISON OF RUNOFFS AND REQUIREMENTS-YEAR OF $75 \%$ PROBABIIITY

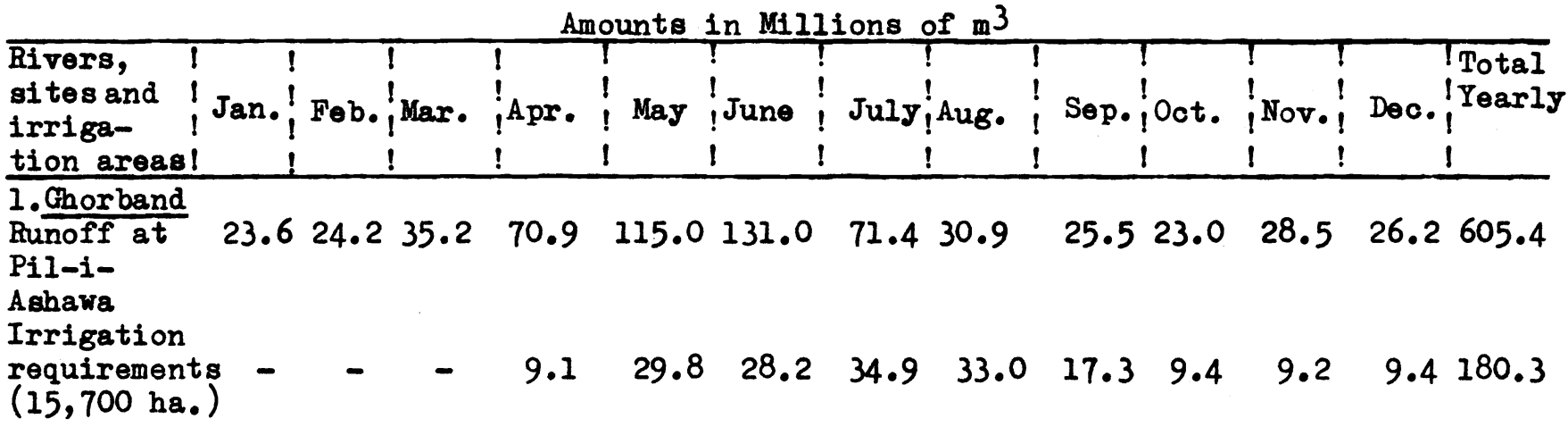


TABLE 67 (cont'd)

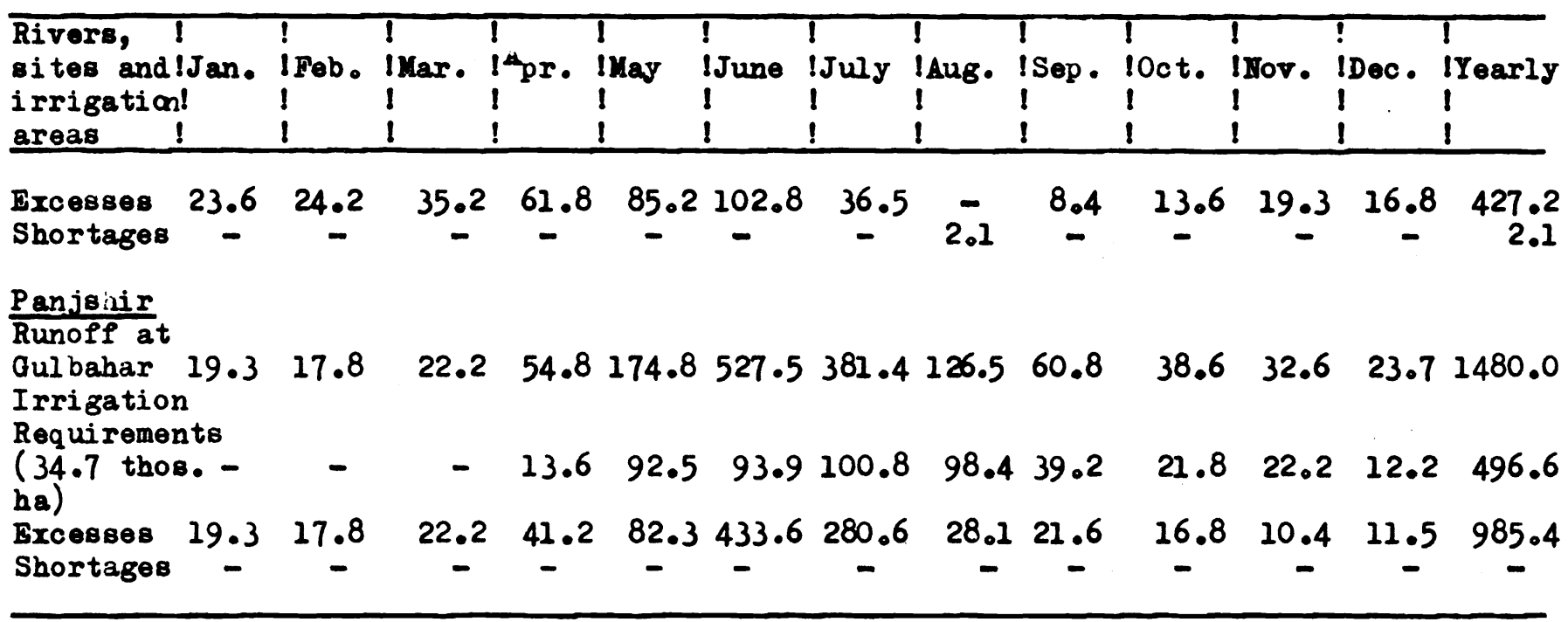

The slight shortage of water in the Ghorband river in August (about $7 \%$ of the monthly requirement) can be easily obviated by a shift of the watering dates.

5. Quantities and Costs of Works. To estimate the quantities and costs of works, use was made of the specific indices derived in the design of irrigation in the Herat Valley, where the layout of a typical plot of land was worked out in detail. However, since in the Shakar-Dara valley the provision of drainage is expected to be required on a smaller proportion of the area than in the Herat valley, the indices of excavation have been adjusted accordingly. The specific indices adopted are as follows:

1. Earthwork

a) Excaration

b) Banking

2. Concreting

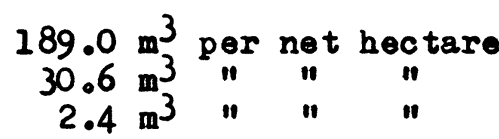

The total quantities of the main work items for the reconstruction of the existing irrigation network and the construction of a new one over the area for development 50,400 bectares, will come to:

1. Earthwork:

a) Excavations

b) Banking

2. Concreting

9495 thos. $\mathrm{m}^{3}$
1537 thos. $\mathrm{m}^{3}$
120.6 thos. $\mathrm{m}^{3}$

The irrigation costs are tentatively estimated on the basis of the following rates:

$$
\begin{aligned}
& \text { Excavation of } \mathrm{I} \mathrm{m}^{3} \\
& \text { Banking I } \mathrm{m}^{3} \\
& \text { Concreting I } \mathrm{m}^{3}
\end{aligned}
$$$$
\begin{array}{ll}
\$ & 0.5 \\
\$ & 1.0
\end{array}
$$

The total cost of the construction of the irrigation system on an area of 50.4 thos. ha will be as follows: 
Excavations

Banking

Conoreting

Total

Items not specified in detail and contingencies ( $50 \%$ )

Grand total
$9,495,000 \times 0.5-\$ 4,748,000$

$1,537,000 \times 1.0-\$ 1,537,000$ $120,600 \times 100-\$ 12,060,000$

$\$ 18,345,000$

$\$ 9,173,000$

$\$ 27,518,000$

The tentative cost of irrigation per hectare in the Shakar-Dara valley will come to 546.0. This is a reasonable rate, which indicates that irrigation development will be advantageous.

\section{KABUL VALLEY}

6. Scheme of Irrigation Development. Of the total area covered by soil surveys, some 140,300 hectares, some 96,700 hectares are in Classes II \& III, definitely suitable for irrigation. Of this total, 60,700 hectares are in the Kabul area, and 36,000 hectares along both banks of the Logar river, But the areas at present intensively irrigated, it is believed, do not exceed 12,000 hectares in the Kabul area, and 15,500 in the Logar Valley. The remainder can only be irrigated intermittently, because of the shortage of water. The main sources of supply are the Bala Maidan (Upper Kabul) \& Logar rivers, together with small supplies from springs, "Karezes", \& intermittent wadis.

All the flows of the Bala Maidan and Logar rivers in summer and autumn, and part of the flows in winter, are intensively used for irrigation. In contrast, much of the peak flood flows in spring cannot be used. Complete utilization of the runoff of these rivers is possible only if reservoirs are constructed.

A preliminary estimate of the water and land balance of the Kabul and Logar rivers shows that, if controlled, the annual runoff of these rivers can irrigate an additional 16,000 hectares. A preliminary scheme of irrigation development in the Kabul valley was worked out on this basis.

The irrigating capacity of the Logar river is considerably higher than that of the Bala Maidan. At the same time, more valuable lands, close to the city of Kabul, lie in the Kabul valley proper. Besides, there are available contour maps on a 1:50,000 scale for a part of this valley, whereas no such topographical information is available for the Logar valley.

Accordingly, the scheme of irrigation development provides for supplying water to the additional lands in the Kabul valley proper, from the Logar river. Even at present, parts of the Kabul valley lands are irrigated from the Logar river, and therefore, the supply of additional water will not be too complicated a proposition.

The scheme of development covers a total gross area of 49,400 hectares, or a total net irrigable area of 43,500 hectares on a land use coefficient of 0.88 . In what follows, figures of areas will be net irrigable areas.

The sources of irrigation of the 43,500 hectares are proposed to be follows:-

(i) To be irrigated from the Kabul river

(ii) To be irrigated from the Logar river
10,500 hectares. 33,000 hectares. 
As regards location, the areas are distributed as follows:-

(iii) In the Logar valley, only the 15,500 bectares now cultivated are to be irrigated, and no new lands are added.

(iv) In the Kabul valley proper, the scheme provides for the irrigation of $28,000 \mathrm{ha}$., out of which the lands now irrigated are 12,000 ha. and the new lands are 16,000 ha. The supply of water from the Logar river to the lands in the Kabul valley proper will be effected by gravity, via a special canal.

The irrigation development scheme for the Kabul valley provides for reconstruction of the headworks and main supply canals for the existing area. In addition it is planned to construct a drainage system for an area of $14,000 \mathrm{ha}$. In order to lower the groundwater level and to reduce salinization of the lands.

7. Cropping Plan and Irrigation Regime. The cropping plan adopted was the same as that used for the Ghorband river, as described in paragraph 3 above. As already mentioned, in working out the irrigation regime, use was made of that evolved for the Herat valley, but modified so far as possible, in accordance with the local conditions in the Kabul valley. A hydro-modulus graph was prepared accordingly (Drg. No. 30) The net overall irrigation requirement per hectare, at the field including presowing waterings, and the irrigation of second crops, is $6884 \mathrm{~m} / \mathrm{ha}$. Taking the efficiency factor of the irrigation system as 0.6 , the gross irrigation requirement per hectare at canal heads is $11,470 \mathrm{~m} 3 / \mathrm{ha}$.

8. Total Water Requirements for Irrigation. Table 68 shows the total water requirements for irrigation of $33,000 \mathrm{ha}$. of lands from the Logar river and 10,500 ha. from the Bala Maidan, month by month throughout the year.

\section{TABLE 68}

\section{KABUL AND LOGAR RIVERS MONTHLY WATER REQUIREMENTS FOR IRRIGATION}

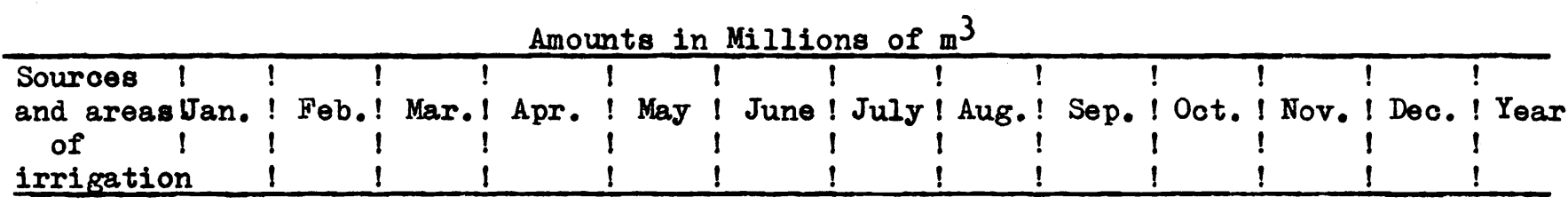

Logar river,

$\begin{array}{lllllllllllll}\text { irrigated - } & - & - & 19.1 & 62.6 & 59.2 & 73.4 & 69.8 & 36.4 & 20.1 & 19.6 & 19.5 & 379.7\end{array}$ area

33,000 ha.

Bala Maidan,

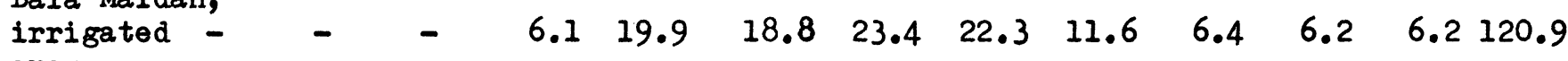

area

10,500 ha.

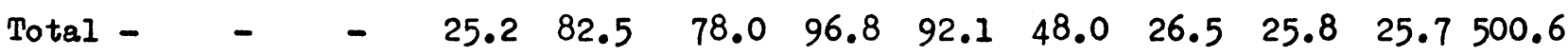

These figures take into account the second crop of maize after wheat on an area of 9,500 heotares, as well as vegetables on an area of 4,800 hectares. The water control by reservoirs necessary to meet these requirements and the design and costs of the works so involved, are discussed in Chapter 22. 
9. Quantities and Costs of Norks. The quantities of the main items of work have been determined on the basis of the specific indices adopted for the reorganization and development of irrigation in the Herat valley. These indices per bectare give the following figures:

1. Earthwork
a) Excavations
b) Banking
2. Concreting

$$
\begin{array}{rr}
255.0 & \mathrm{~m}^{3} \\
30.6 & \mathrm{~m}^{3} \\
2.4 & \mathrm{~m}^{3}
\end{array}
$$

The total quantity of the main work items for the reconstruction of the existing irrigation system, and the construction of a new irrigation system, over 43,500 bectares in the Kabul valley, will come to:-

$$
\begin{array}{lr}
\text { 1. } \frac{\text { Barthwork }}{\text { a) Brcavation }} & 11,092,500 \mathrm{~m}^{3} \\
\text { b) Banking } & 1,331,100 \mathrm{~m}^{3} \\
\text { Concreting } & 104,400 \mathrm{~m}^{3}
\end{array}
$$

The cost of irrigation construction has been tentatively based on the rates that were adopted in eģtimating the cost of work for the Herat and Farah valleys, that is: excavation of $I \mathrm{~m}^{3}$ of earth $-\$ 0.5$, Banking $\left(\mathrm{I} \mathrm{m}^{3}\right)-\$ 1.00$, and concreting ( $\left.\mathrm{Im}^{3}\right)-$ $\$ 100.00$

Therefore, the total cost of the irrigation system here on a total area of 43,500 hectares will come to:

Bxcavations
Banking
Concreting
Total
Smaller items not
opecified in detail,
and contingencies
$(50 \%)$

Grand total

$$
\begin{array}{r}
5,546,300 \\
1,331,100 \\
\$ 10,440,000 \\
\hline
\end{array}
$$

$\$ 17,317,400$

Consequently, the tentative cost of the irrigation of one hectare of lands in the Kabul valley (excluding reservoirs) will be $\$ 597.0$.

Including the construction costs of the Tangi Saidan and Kajao reservoirs, the specific expenditure for the irrigation of one hectare of lands in the Kabul valley will bes ha will be:

$\$ 597+\$ 360=\$ 957$, accordingly the total cost of the irrigation on 43.5 thos.

$$
25,976,000+15,648,800=\$ 41,624,800 \text { 。 }
$$

The specific expenditure indices for the construction of an irrigation system and reservoirs in the Kabul valley are of course high as compared with that for the Shakar- Dara valley, where reservoirs are not proposed. However, these expenditure indices are close to those determined for the similar irrigation development schemes for the Herat and Farah valleys. 
1. It has been shown that Class II and III lands in the Kabul basin form in all a considerable area, of over 173,000 hectares, of which little more than $50 \%$ is annually irrigated. These solls have a good texture, adequate vertical and horizontal drainage, and are almost completely free from salinity. Their location near Kabul city, in the most densely populated areas of the country, contributes to the significance of irrigation development here.

2. Although a wide variety of other crops is grown, irrigated agriculture here at present is concentrated mainly on the produotion of grain orops, whioh ocoups up to $70 \%$ of the annually sown areas, with the remaining $30 \%$ under summer orops.

3. The irrigation development of all Class II and III lands, and the introduction of more valuable orops, including cotton, sugar-beet, and o1lseeds, should be one of the most important tasks in planning irrigated agriculture in the Kabul basin in the near future. The implementation of this task beoomes still more important by reason of the fact that the growing domestio textile and sugar refining industries will be located in this basin and will require raw materials for their development.

The preliminary soheme proposess To increase the intensively irrigated area in the Shakar Dara valley from 21,600 heotares to 50,400 heotares wi thout water control, and in the Kabul valley, from 27,500 heotares to 43,500 heotares on the basis of water control of the upper (Bala Maidan) and Logar rivers. However, this soheme of irrigation development should be considered as striotly tentative; it should be reviewed and elaborated after receipt in Afghanistan of the contour maps which are at present being prepared in the USA, and upon the further study of the irrigated lands in the existing conditions.

4. In Volume VI are given the results of preliminary economio estimations of the relationship between the value of the produotion to be expeoted, (a) on first development; (b) on ultimate operation $-20 \%$ higher, and the costs of achieving that produotion. It is there assumed, reasonably, that of the total value of production, $60 \%$ will be absorbed in meeting costs of operation, taxation etc, leaving $40 \%$ available, as profit, to be used for repayment. The capital costs estimated in Chapters 22 and 23 are net, and include no allowances for interest and amortisation during the period of construction and development. If this period is taken as 3 years, and interest at $10 \%$ and amortisation at $2 \%$ are allowed for, then it is estimated that the total gross costs will be $23 \%$ more than the net figures.

In Table 69, are shown figures of the resulting comparisons, and of the periods required for repayment, on the basis of both net capital costs and gross capital costs, for each of the three proposed areas of irrigation development in the Kabul. basin. 
TABLE 69

KABUL BASTN - SPECIFIC COSTS, PROFITS AND PERIODS FOR REPATMENT

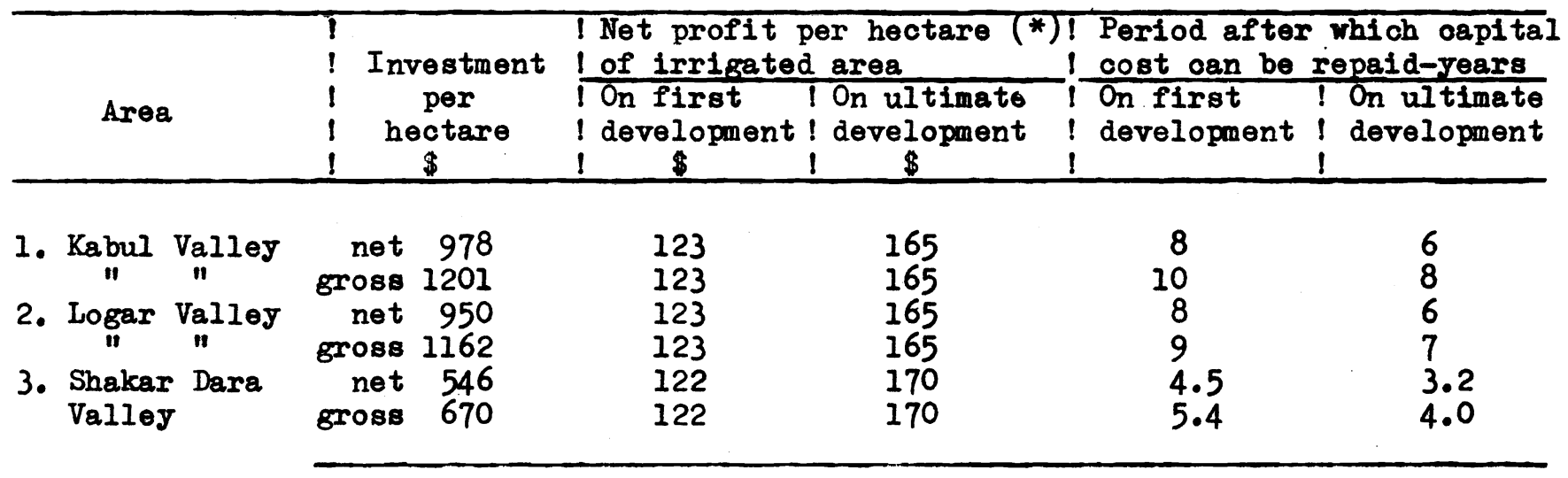

(*) These profits, resulting from improved agricultural methods, mechanisation use of fertilizers, etc, will require considerable longer periods than the 3 years of construction.

Comparison of the figures of the periods after which the capital expenditure will be returned indicate that development in Shakar Dara valley is economically preferable and therefore, this valley should be given first priority in the implementation of the planned measures for irrigation development of the Kabul basin.

5. Irrigation development on a major or minor scale will require, apart from the construction of reservoirs, construction of new irrigation systems and reconstruction of these existing, as well as the establishment of regulating works on the irrigation canals, so that effective control can be introduced over the distribution and use of water.

6. At the same time, it is necessary immediately to introduce on a large scale all the new and advanced methods of agriculture, that have been tested on the researchexperimental agricultural stations in the country. Modern techniques of cultivation, proper crop rotation systems, and the use of mineral fertilizers should be given full attention in the cultivation programme of every farmer.

7. To operate the hydraulic works, to regulate the water distribution, and to keep the means of drainage and reclamation in good working condition, a government organisation or agency for water economy management must be established as soon as possible in every major river basin, including the Kabul basin.

8. The construction of reservoirs will result in the flooding of some villages, farmsteads and cultivated lands, occupying the lands along both banks of the Kabul and Logar rivers, within the backwater area, i.e. to some 13-15 kilometres above each dam. Peasants' farms, cultivated lands and some dirt roads will be put out of use.

The loss so incurred by the peasants for their flooded farmsteads and cultivated lands will be more than made good, by the development of new lands that will many times exceed the flooded lands in area. However, the peasants whose lands and villages are to be flooded may not agree to resettlement in new areas, may not be willing to leave the localities where their ancestors have lived for many generations. 
Cases have already occurred of peasants' petitioning during the course of surveys and investigations in the areas of the proposed reservoirs. This should be kept always in mind in planning survey work for the next, possibly pre-construotion, stage of the project.

9. It is neoessary in conolusion to say that irrigation development in the Kabul basin has without doubt, very good prospects. However, since the measures recommended by this projeot are based only on reconnaissance survejs and on a very tentative estimate of costs, they should be examined in much fuller detall by further surveys and investigation, before final decisions are taken.

10. The development of hydro-electric power at the proposed dams at Tangl Saidan and Kajao would not be justified, beoause no water will be released from them for long periods each year, when irrigation requirements are nil. 
SECTIOI V - BASIISS OF CIIAZMI AND MABAR RIVERS

CHAPTHR 25 - DESCRIPIION OF BASTHS

1. Channi River This river rises at a height of about $3000 \mathrm{~m}$., some $55 \mathrm{Km}$. north of the oity of Chazni. It flows into the salt lake of Ab-1-Istada, about $1968 \mathrm{~m}$. above sea level, in the south-western portion of the Chazni Province.

From source to mouth, the Chazni river 18 about $190 \mathrm{Km}$. long, and its oatohment area totals $12,370 \mathrm{Km}^{2}$. Near its source, the river is torrential and flowe in a wide mountain valley. On this stretoh it has slopes up to $i 5 \mathrm{~m}$. per kdlometre. The lower river flows in a very wide valley and has an average gradient of $1.3 \mathrm{~m}$. per kilometre towards the Ab-1-Istada lake.

In the mountainous part of the basin, the watershed is as high as $4000 \mathrm{~m}$, whereas in the valley it drops to $2000 \mathrm{~m}$.

About $18 \mathrm{~km}$. above Ghaznl there is a dam, $35 \mathrm{~m}$. high, with reservolr capacity of 20-25 million $\mathrm{m} 3$, which stores flood water, to improve the supply to local lands and to inorease the irrigated area under summer orops. Because of heavy abstractions of water for irrigation, the middle and lower reaches dry up in summer.

The Jilge river is the largest tributary of the Chazni. Its sources are situated at a height of $3860 \mathrm{~m}$., its length is $152 \mathrm{Km}$. and its catahment area is $4380 \mathrm{Km}^{2}$. Since 1961 an earth dam has been under construction on the Jilga, $26 \mathrm{~m}$. high, to store up to 125 million $\mathrm{m}^{3}$, for the irrigation of an estimated maximum area of 13,200 heotares, mainly grain orops.

2. Wahar River The river rises at a height of about $3000 \mathrm{~m}$, , and flowe, like the Gharni river, into the Ab-1-Istada lake. Its total length is $133 \mathrm{Km}$, and the catohment area is $3710 \mathrm{~km}^{2}$. Through the greater part of 1 ts length, the river flows in a wide flat valley. The maximum heights of the watershed reach $3300 \mathrm{~m}$.

During the entire summer period the lower Nahar river has no water, since the streams which feed it have already been exhausted in the mountainous part of its basin to irrigate the meagre plots of land along the banks of these streams and in the upper valley. In the lower valley however groundwater irrigation is very popular, either by lift from wells, or through a highly developed network of karezes.

3. Climate The Nahar and Ghazni basins adjoin each other, and the meteorological oonditions can be taken as the sane. In general, these basins are oharacterized by a moderately hot climate.

There is only one meteorological atation in the area at Chazni, with a five-year series of observations. To give an impression of the olimate, estimated data are given, based on those from the Ghaznl and Kabul stations.

a) Air temperatures

The table belor gives data on the mean monthly temperatures for the Chazni meteorological station, extends to a 30-year series, and estimated temperatures for basin heights of $3000 \mathrm{~m}$. 
TABLE 70

GHAZNI AND NAHAR BASTNS - MEAN MONTHEY AIR TTEMPERATURES

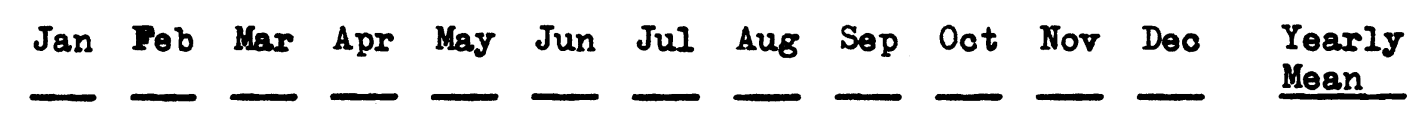

Chazni

$\begin{array}{lllllllllllllllllll} & (2150 \mathrm{~m})-5.7 & -3.7 & 4.9 & 10.9 & 14.9 & 19.1 & 21.8 & 21.0 & 15.6 & 9.3 & 4.5 & -2.0 & 9.1\end{array}$

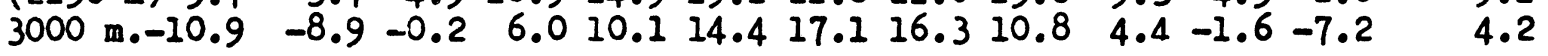

b) Precipitation

In the area of the two rivers and particularly in their valley parts, precipitation occurs during November-May. Only rarely, due to the influence of the Indian monsoon, does considerable precipitation take place in June and July.

Precipitation occurs mainly in the shape of snow, which rarely forms a permanent cover at heights under $2000 \mathrm{~m}$. In the higher parts of the basin the snow cover lasts throughout the cold period, and melts completely by mid-July.

Table 71 gives the mean monthly values of the precipitation distribution in the Ghazni basin at heights of 2000-2500 m. for a 5-year period at the Chazni station.

\section{TABLE 71}

CHAZNI BASIN - MEAN MONTHLY PRECIPITATION : MILLIMETRES

\begin{tabular}{|c|c|c|c|c|c|c|c|c|c|c|c|c|}
\hline Jan & Feb & Mar & Apr & May & June & July & Aus & Sept & Oot & Nov & Deo & $\begin{array}{l}\text { Ann- } \\
\text { ual } \\
\text { Mean }\end{array}$ \\
\hline 39.1 & 29.7 & 65.5 & 66.6 & 26.7 & 11.0 & 38.1 & 1.0 & 0 & 0 & 22.4 & 33.6 & 334 \\
\hline
\end{tabular}

It may be supposed that in the high-altitude part of the basin precipitation is about $400 \mathrm{~mm}$.

In the Nahar basin precipitation is somewhat less than at Chazni. It is presumed that in the Nahar basin precipitations over a period of years range from 250 to $350 \mathrm{~mm}$., acoording to elevation.

c) Evaporation

The oomparatively high air temperatures, low humidities and frequent strong winds in the Ghazni basin create conditions for fairly high rates of evaporation.

Below are given estimated values of the mean monthly evaporation in mm., computed on the basis of the air temperature and relative humidity at the Ghazni meteostation. 
TABLE 72

GHAZII BASIN - MEAN MONTHLY EVAPORATION \& MILIIMETRES

\begin{tabular}{|c|c|c|c|c|c|c|c|c|c|c|c|}
\hline Jan Feb & Mar & Apr & $\mathrm{May}$ & June & July & Aug & Sep & Dot & Nov & Deo & $\begin{array}{l}\text { Annual } \\
\text { Mean }\end{array}$ \\
\hline 50 & 100 & 140 & 180 & 190 & 200 & 190 & 140 & 100 & 60 & 40 & 1420 \\
\hline
\end{tabular}

As already mentioned, climatio conditions in the Nahar basin are similar to those in the Ghanni basin, and therefore the evaporation values, mean monthly as well as annual, will be close to those estimated for the Chazni basin.

4. Flore and Fauna. The areas survejed in both these vallejs have little vegetation, conforming in general to the same pattern as the lower areas of west and south-west Afghanistan, as described in Chapter 1. Soattered patahes of treees and sorub occur in the mountain areas, with low bushes and ephemeral grasses and other plants in the valleys. This scaroity of plant cover has left its impression on the soll, which is poor in iumus. Animal life, again, is similar in general to that at equivalent altitudes in the other valleys surveyed.

5. Population. No official data are available as to the size and composition of the population of the Chazni Province. According to unofficial information, around 600,000 reside in the Province. The main city - Ghazni, the anoient capital of Afghanistan - has a population of about 20,000 .

The main source of livelihood for the population is irrigated agriculture and animal husbandry, which give occupation to over $85 \%$ of the people.

The large landlords, renting their lands out on a share-cropping basis, also engage in commerce, both within the country and with Pakistan. The imports are consumer goods, such as fabrics, sugar, tea and matches, fuel, tobacoo, eto.

There are virtually no industrial enterprises in the provinces, but small handioraft establishments number perhaps as manj as 2,000 .

A characteristio disproportion in the Ghazni province is the availability of large areas of irrigable lands, and also of manpower for their development, on the one hand, and an acute shortege of irrigation water on the other.

6. Roads and Communications. Ghazni city, the capital of the province, is situated on the main circular highiray linking it with Kabul and the other principal oities of the country. The lands surveyed under the Projeot lie 10 to $80 \mathrm{Km}$. to the east of this road. Dirt roads conneot the main highway wi th the main distriot centres of the provinoe. They are motorable for the greater part of the year, except during the rainy season and in spring when torrent debris often destroys stretches of road and bridges.

As elsewhere in the country in spite of the increasing use of trucks, much internal goods transport is still done by pack animals. Telegraph and telephone communications are available between Ghazni and important national and provinoial centres. 
CHAPTER 26 - SOILS AND EXISTING IAND USE

1. General Information. The area surveyed is situated, administratively, mainly in the Chazni province; part only lies in the western portion of the Pakhtya Province, where the sources of the Nahar and the Jilga (left bank tributary of the Chazni River) are looated.

Soil surveys were carried out in the following areas:

(i) The valleys of the Ghazni and its tributary, the Jilga - on a total area of 389,990 heotares;

(ii) The valley of the upper and middle Nahar - on a total area of 123,400 hectares;

(iii) The Dil district, with the addition of lands situated around the Ab-i-Istada lake (lower Ghazni and Nahar and upper Lora) - on a total area of 310,000 heotares;

(iv) The Katawaz area around the village of Wazi Khwa - on an area of 54,900 hectares. This is the extreme southern portion of the Ghazni province, and the lands are situated very near to the Pakistan border.

It should be noted that under the revised Plan of Operations, it was intended that, apart from these areas, the Gomal basin should also be surveyed. But in September 1962 the Government made a verbal statement that, because of unsuitable conditions for visiting the Gomal basin, which lies in a border area, it would not be desirable to proceed at that time with these surveys.

Therefore, the study of the land and water resources in the Gomal basin was excluded from the Project's programme of work, and it was replaced by soil surveys in the Jilga basin (left bank tributary of the Ghazni river).

The elevation of the lands surveyed is from 2000 to $2400 \mathrm{~m}$.

On account of a shortage of suitable maps, the soil specialists started with a visual survey, late in May 1962.

This visual survey resulted in a brief preliminary report at the end of July 1962.

Further study of the soils was cerried out in the period from September 1962 till August 1963, using the data collected during this preliminary visit.

This investigation covered a total area of 878,290 bectares. The field work and laboratory analyses of soil specimens resulted in preparation of soil maps, and also maps of land classification and use under the present conditions, separately for each area surveyed. The major portion of these maps were prepared on the basis of the Fairohild topo-maps (scale 1:50,000) received in the second half of 1962 for a part of the Chazni province. 
2. Desoription of So1ls. The Chazni plateau, situated among the mountains, includes thick colluvial-alluvial deposits. The areas surveyed form the lower and flatter parts of the valleys sloping down from the adjoining low plateaus, with atrips of the alluvial valleys of the Jilga, Ghazni and Nahar.

In respect of landsoape and climate, the area survejed mainly represents the zone of wormwood steppes of the montane semi-desert, with development of soils that refer to desert types.

The areas surveyed are partially irrigated, and partly still bear the traces of ancient irrigation: the fallows of various ages are represented by light-coloured desert soils, poor in humus. The soils are largely silty loams and light olays, which have, in many cases, favourable physical propertios.

In every locality surveyed there are small areas where in depressions groundwaters flow out from underground streams coming from the higher areas. Hovever, under the present conditions of irrigation the underground water does not take much part in the soll formation over most of the areas, and only on the low areas beside river beds and in places under intensive irrigation is its effect seen in the salinization of the solls.

The existence of a well-developed system of karezes has a pronounced effect on the underground water regime, and contributes very much to the favourable condition of the greater part of the area surveyed.

However, a considerable portion of the lands around the Ab-i-Istada lake (up to 50,000 hectares) are medium to highly saline, with a high (0.60 m. to $1.50 \mathrm{~m}$. level of highly and medium saline ground waters, directly related to the formation of these saline soils.

The soil reports (Volume IV - Soils) give a detailed desoription, specifioally for each surveyed area, of each type of soll, based on the data provided by a study of the soil profiles and their laboratory analyses. They supply a morphologioal description of soils, their characterizing series: terrain, drainage, land use, groundrater condition, texture of soil samples, etc.

3. Land Resouroes. Table 73 shows the classification of the lands surveyed.

\section{TABLE 73}

GHAZII PROVINCE - LAND CLASSIFICATION

Name of Surveyed Area

1. Valleys of Ghazni \& its tributary Jilga

2. Valley of upper \& middle Nahar

3. Dil area - around Ab-i-I stada lake

4. Waz1 Khwa (Katawaz)
Total Area: Survered (ha)
Classes of Land

Classes of Land
II II IV V II

\begin{tabular}{rcrrrr}
389,990 & 76,150 & 74,040 & 40,920 & 110,880 & 88,000 \\
123,400 & 5,600 & 43,000 & 19,300 & 10,500 & 45,000 \\
310,000 & 74,740 & 65,000 & 15,230 & 35,530 & 119,500 \\
54,900 & - & 11,600 & 14,000 & 6,000 & 23,300 \\
\hline 878,290 & 156,490 & 193,640 & 89,450 & 162,910 & 275,800
\end{tabular}


4. Present Land Use. The river Chazni with its tributaries and the river Nahar are the sources of irrigation. The run-offs of these rivers, except during the flood period, are fully taken up for irrigation. In all the areas surveyed, and especially in the Nahar valley and the Nazikhwa area, ground waters are also successfully used for irrigation through a highly developed system of "karezes" and also from wells equipped with pumps or other water-lifting devices.

The main crops on the irrigated lands are winter grains (wheat and barley), maize and fodder orops - alfalfa and Persian olover. The proportion of melons and vegetables, rioe, orchards, vineyards, eto. is limited.

Dry-farmed crops are grown on a small area, but they are of little importance as their yields are always low, even in years of good rainfall. At best, the peasants get a threefold yield on the seed sown.

The orop-fallow system of agrioulture is a characteristic feature of the farming in the province. A plot is sown to crops for one year, followed by 3-4 years fallow.

Irrigation from the rivers is effeoted through numerous canals. In particular, 5,200 heotares of land in the middle part of the Ghazni valley are irrigated by 47 canals, each with a separate intake from the river. These intakes are repeatedly destroyed by floods. Water distribution for the canals is ohaotio and uncontrolled.

"Karez" irrigation is highly developed, as has already been indioated, in the Nahar valley and the Wazi Khwa area. The Karezes flow at depths of 5 to $16 \mathrm{~m}$. below the surface and the inspection wells are spaced out at 20-25 metres. A "Karez" canal irrigates from 5 to 80 hectares, and is owned by 3 to 20 families. The water discharges from the karezes range from 3 to 50 litres/sec. As a rule, the irrigation plots are well levelled; in most cases they are flooded and only rarely are they watered through furrows.

No mineral fertilizers are used; local manure is used only on a very insignificant part of the area.

Table 74 below gives land areas and describes their use under the existing conditions separately for each area surveyed in the Ghazni provinoe.

PABLE 74

GHAZNI PROVINCE - EXISTING LAND USE

Land Use

Area

hectares

$\%$ of total area

Valleys of Chazni river and its tributary Jilga

1. Annually irrigated lands

2. Fallow, or intermittently partially irrigated, lands uhder dry farming

3. Lands used as pastures:

Complex of irrigated non-saline and non-irrigated lands

b) Highly eroded saline lands

c Consolidated and non-consolidated lands

d) Eroded stony lands

\begin{tabular}{rr}
43,970 & 11 \\
100,800 & 25 \\
30,400 & 8 \\
57,090 & 14 \\
68,520 & 18 \\
89,210 & 24 \\
\hline 389,990 & $\overline{100}$
\end{tabular}

11

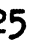

18

24 
TABLE 74 (Cont'd)

Land Use

Area $\%$ of

hectares total

$\underline{\text { area }}$

Upper and middle Nahar Valler

1. Annually irrigated lands

2. Lands used for pastures and partially for dry farming crops:

a) Froded, non-irrigated lands used for pastures

b) Fallow, non-irrigated lands used for pastures and dry farming orops

3. Saline, thin lands used only for pastures TOTAL

$\begin{array}{rr}9,010 & 7 \\ 33,790 & 27 \\ 21,820 & 18 \\ \frac{58,780}{123,400} & \frac{48}{100}\end{array}$

Dil Area - around Ab-1-Istada Lake (Lower Chazni and Nahar and Upper Lora)

1. Annually irrigated lands

2. Intermittently partially irrigated lands and lands used for dry farming

3. Lands used for pastures:

a) Complex of saline and dry farming lands

b) Highly aline (meagre pastures)

o) Eroded skeletal so1ls

TOTAL

\begin{tabular}{rr}
10,000 & 3 \\
139,000 & 45 \\
26,000 & 8 \\
50,000 & 16 \\
85,000 & 28 \\
\hline 310,000 & 100
\end{tabular}

\section{Kataraz}

1. Annually irrigated by karezes and household plots

2. Lands used for dry farming crops and pestures:

a) Non-irrigated, partially cultivated plots and lands

$$
\begin{array}{rr}
2,870 & 5 \\
8,250 & 15 \\
9,590 & 17
\end{array}
$$

b Eroded non-irrigated, partially cultivated lands

c) Complex of non-irrigated, partially cultivated saline lands

3. Lands used only for pasturess
a) Salino virgin lands
b) Lands with undulating terrain and stons patabes
TOTAL
Grand total for surveyed areas of Ghazni Provinoe
Inoluding:
Unconditionally suitable for irrigation Class II
and III lands.
out of which:
there are now irrigated only

$14,060 \quad 26$

6,300

12

13,830

15

54,900

$\overline{100}$

$878,290 \quad 100 \%$

350,130

65,850 or $19 \%$ 
1. Initial Data The appraisal of the regime of the Chazni and Nahar rivers, their flow and sediment disoharge, as well as the minimum discharge, is based on the observations at the gauging stations at Noorbuja, on the Ghazni river, for 1962, and at Sardeh, on the Jilga river, for 1957, and also on the analogous data for the Nurtaza station, on the Comal river, situated in Pakistan, where observations have been carried out over the period from 1929 through 1953. The appraisal below must therefore be taken as very approximate. As hydrological data aocumulate, the run-off values should be more olosely estimated.

2. Regime of the Chasni and Nahar rivers The low elevations and limited extents of catchments, the existence of depressions that have no flow, soant precipitations which usually oocur during the oold season, instability of the snow cover, contribute on the whole to the fact that run-offs on the Chazni and Nahar rivers are relatively low. Floods on these rivers start in Maroh, when snow begins to melt in the mountains and rainfall intensifies, and end in May or June. In the summer and autumn-winter periods the run-off is entirely taken for irrigation.

3. Normal Annual Run-off The basis for the estimation of the normal annual run-off of the Ghazni and Nahar rivers is given in Volume III - Hydrology. Table 75 shows the estimated figures of this run-off.

TABLE 75

CHIZNI AND NAHAR RIVERS - TOBMAL ANNUAL RUN-OFFS

Name of River

Ghazni at mouth Nahar at mouth
Mean Discharge $\left(\mathrm{m}^{3} / \mathrm{sec}\right)$
Normal Annual Pun-off in mill. $\mathrm{m}^{3}$
11.0
3.0
346
94

4. Fluctuations of Annual Flow Table 76 gives estimated figures of the data of the hydrological variations in the anmual run-offs of various probabilities on the rivers of Chazni and Nahar at their mouths.

\section{TABLE 76}

GEAZNI AND MAHAR BIVERS - AMUUA FLOW PLUCTUATIONS

Name of River

$$
\begin{aligned}
& \text { Nean Annual Water Discharges in } \mathrm{m}^{3} / \mathrm{seo} \text {. at \% Probability } \\
& \begin{array}{llllllllll}
1 & 3 & 2 & 10 & 20 & 50 & 75 & 25 & 21 & 22
\end{array}
\end{aligned}
$$

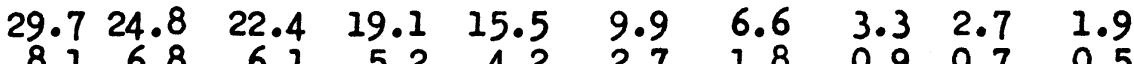

Ghazni

Nahar

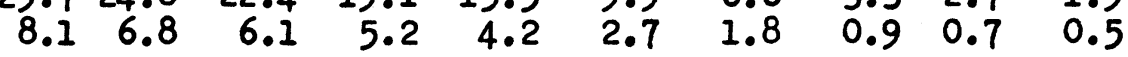


5. Run-off Distribution Within the Year The main part of the Ghazni and Nahar run-offs come down during the spring months, primarily due to the rainfall. Over the rest of the year these rivers are fed either by the seasonal snow melting. in the mountains, or by the underground sources which are almost entirely used upstream for irrigation for almost four months - from July to October. The distribution of the Iun-off of these rivers within the year is very irregular, but is similar for both rivers.

\section{TABLE 77}

\section{GHAZNI AND NAHAR RIVERS - DISTRIBUTION OF RUN-OFFS WITHIN} THE YGAR IN \%

Jan. Feb. Mar. Apr. May June July Aug. Sep. Dot. Nov. Dec.

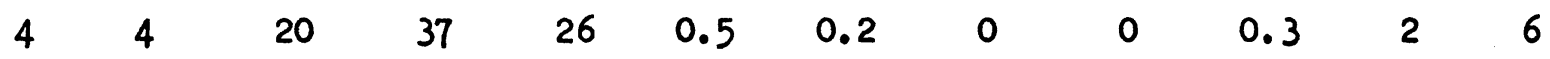

For the Year - 100

The seasonal distribution of the Ghazni and Nahar flow in percentage of the annual run-off amounts to:

$$
\begin{array}{lr}
\text { Spring (March-May) } & 83.0 \% \\
\text { Summer-Autumn (June-October) } & 1.0 \% \\
\text { Winter (November-F'ebruary) } & 16.0 \%
\end{array}
$$

It should be noted that the sumper, autumn and winter run-off of the Ghazni river, $17 \%$ of the total or 35 mill. $\mathrm{m}^{3}$ in a year of $75 \%$ probability, is entirely taken for irrigation. Of the spring run-off, $83 \%$, or 172 mill.m $\mathrm{m}^{3}$, over $1 / 5$ is controlled by the Band-i-Sultan reservoir, and over $3 / 5$ will be put under control, from late in 1964, when the Sardeh reservoir is in operation, as described in Chapter 28. Thereafter, all the seasonal run-off in the Ghazni basin will be almost fully regulated.

6. Maximum Discharges Those are shown in Table 78 below.

\section{TABLE 78}

GHAZNI AND NAHAR RIVERS - ESTIMATED MAXTMUM DISCHARGES

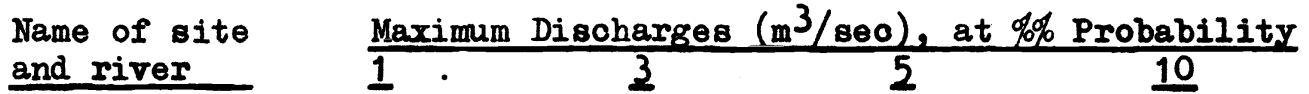

$\begin{array}{lllll}\text { Ghazni Mouth } & 770 & 600 & 520 & 410\end{array}$

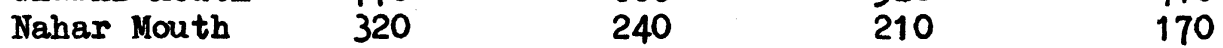

7. Sediment Discharge Volume III - Hydrology - gives information on the anmal suspended load disoharge, based on the data on the silt load and the normal anmul run-off. 
As is evident from the hydrological data, the Ghazni and Nahar rivers heve relatively limited surface water resources, especially from June to February, that is, after the passing of the flood. As to the Wazl Khwa (Katawaz) situated in the southern part of the Ghazni Province, south and south-east of the Ab-i-Istada lake, this area practioally has no surface waters.

At the same time, the Province is in possession of very large resources of lands in the areas surveyed. As shown in Chapter 26, the total area of Class II and III lands, unconditionally suitable for development of irrigated agrioulture amounts to 350,100 hectares, out of which only 65,800 hectares, or about $19 \%$, are annually cultivated and irrigated under the present conditions.

Such a major disproportion in the land and surfece water resources cannot be rectified, despite the fact that a portion of the spring flood waters of the Ghazni and Nahar rivers is not used and flows into the Ab-i-Istada lake.

As already mentioned in Chapter 27, the spring flood waters in the Chazni basin are already partially controlled by the existing Band-i-Sultan dam on the Chazni river upstream of Ghazni city. This, originally built centuries ago, was reconstructed about 1940. It is a concrete and masonry dam, $35 \mathrm{~m}$. high, forming a reservoir with a capacity of $30 \mathrm{mill} . \mathrm{m}^{3}$. The Sardeh reservoir on the Jilga river, formed by an earth dam $26 \mathrm{~m}$. high, with a capacity of $125 \mathrm{mill}$. $\mathrm{m}^{3}$, has been under construction since 1961, and will be completêd in 1964. The total capacity of the two reservoirs will come to about $165 \mathrm{mill} . \mathrm{m}^{3}$, approximately $78 \%$ of the total annual run-off of the Chazni basin in a year of $75 \%$ probability.

In effect almost all the seasonal mun-off in the basin will be controlled by these reservoirs. However, since it is to be expected that the available storage of these reservolrs will have silted respectively after 10 and 25 years, new capacities will be needed to regulate the run-off. In this connection, a study was carried out on aerial photographs and topo-maps, as well as field trips, to looate potential sites for storage dams on the Ghazni and Nahar rivers. The results of the surveys show that on the mountain stretches of these rivers, notwithstanding the availability of possible sites for dams up to $40 \mathrm{~m}$., the steep gradients of 15-20 m. per kilometre, as well as the narrow gorges, limit the reservoir capacities to such an extent that construction of dams there would be unprofitable. The silt life of such reservoirs, if constructed, would not exceed 10-12 years, which is too short to be justified.

Conditions for building economically justified reservoirs do not exist in the valley parts of these rivers. However, a proposal has been mooted for a reservoir at Paltu, on the Jilga river, some distance upstream form the Sardeh dam, to have a capacity of 30 mill.m $\mathrm{m}^{3}$, sufficient for the irrigation of 3000 hectares. This was taken into account in considering storage at Sardeh. The Paltu reservoir could not be required in less than 20 years time, when the allowance for dead storage at Sardeh will be silted up, and its effective capacity begins to be diminished. 
Since no possibility could be discovered of providing additional water for the Ghazni and Nahar rivers from other basins, this idea is ruled out.

The available unused resources of underground waters, however, could be considered for at least partial irrigation development in the future, in the Ghazni Province. But this could be decided upon only after further hydrogeological investigations, as mentioned in Chapters 29 and 30. 


\section{CHAPTER 29 - IRRTGATION DEVELOPMENT}

1. General As alreedy shown in Chapter 28, the Ghazni Province as a whole has large potential land resouroes suitable for irrigation. Therefore, the Government of Afghanistan has for a number of years been raising the question of possible irrigation development of at least a part of this land potential.

Loval investigations and studies towards this end were started in recent years with the assistance of some foreign organisations. In particular, from 1952 to 1954 the American company Morrisson-Knudsen began, and the "Technopromexport" (USSR) company finished in 1958, comprehensive investiagtions for storage dams at Sardeh and Paltu in the upper Ghazni basin. The dam at Sardeh, as already mentioned, will be completed in 1964.

The capacity of this reservoir will increase by 13,000 hectares the irrigated lands of the Province, growing the present range of crops, that is, mainly grain crops. It would have been desirable by the time the reservoir came into operation to have a water intake, irrigation system and new lands reclaimed and prepared for irrigation. However, an irrigation system, far from being built cannot jet be designed as no surveys have ever been started in the block of land that is earmarked for irrigation in the Andara area. In this area, commanded from the Sardeh dam site, at present an irrigation system exists over an area of only 240 bectares irrigated from the Jilga river.

Part of the stored water might be used to irrigate free lands in the lower Ghazni basin, but this would require reconstruction of the existing irrigation system, the oapacity of which is very limited, to say nothing of the fact that this system has not even the most elementary regulating works or measuring equipment.

This suggests a laok of coordination, as far as capital investment is concerned, which has resulted in the state funds being frozen for several years, due to the impossibility of using at once to the maximum and in a reasonable way the stored water for irrigation development.

As described in Chapter 28, conditions for further storage of water on the Ghazni and Nahar rivers are absent.

2. Ground Water Resources The hydrogeological investigation made in parts of the Province show some possibilities of developing irrigation by using groundwater. Because of lack of time, funds and the necessary equipment, this survey in the Nahar valley was carried out visually, without any drilling, through inspection of rock outcrops, wells, karezes, etc. (The Plan of Operation of the Project made no provisions for special hydrogeological investigations).

The engineering geologist's report in Volume II shows the stratigraphy, available rocks and their locations, and gives brief considerations as to the extent of the water-bearing strata and the quality of underground water; a description is given of the present utilization of the groundwater through karezes and also wells equipped with lifting devices. 
The preliminary conclusions are that artesian waters are absent in the mountain formations of the Nahar valley surveyed. The main aquifers are considered to be the Pleistocene gravels and overlying alluvium on the side slopes.

Based on the preliminary data of the survey, the conolusion is that the Nahar valley has considerable ground water reserves. However, to establish their potential and quality and the possibilities of their use for irrigation development, special hydrogeological investigations are necessry.

At present, a new Special Fund project is being undertaken. - "Survey of Underground Water in a Kumber of Areas in Afghanistan". (see Chapter 2, section 15) The Project will include a part of the Ghazni Province, over an area of $22,800 \mathrm{Km}^{2}$ in Katawaz.

The surveys of the present Project in the Ghazni Province were restricted to studies of the land and water potential. The preparation of a draft scheme of irrigation development must await the completion of the hydrogeological investigations. 
CEAPTHER 30 - CONCLUSIONS AND RECOMUTERDATIONS

1. In aooordanoe with the land olassification in the areas aurveyed for solls, the total area of Classes II and III so1ls suitable for irrigation amounts to 350,700 heotares. Out of this acreage only 65,800 heotares, or $19 \%$, are anmually used for irrigation.

The soils of these classes have, as a rule, good texture; they are loamy, with a thiok soil cover, non-saline and have quite satisfaotory physioal qualitien.

Provision of water for the lands 1s the cardinal problem to be solved before anj irrigation development, major or minor, is undertaken.

2. Classes IV and V lands, on an area of 252,400 heotares, are mainly used as pastures at present and are little suitable for irrigation, but, given water, they could be used in plots for irrigated orops, and plantations, to improve, first, the fodder supplies for animals, and second to provide fuel, to improve the mioroclimates and to reduce or prevent wind erosion of the solls.

3. Irrigated agrioulture using river water at present mainly grows winter grain orops, particularly wheat and barley, which occupy over $90 \%$ of all the annually Irrigated lands; only up to $10 \%$ of the area is oocupied by summer orops. On the lands irrigated by groundrater, from the highly developed system of karezes and by lift from wells, proportions of the orops grown are different. Not less than $50 \%$ of these areas are used for summer crops (vegetables, melons, or ahards, vineyards, etc.) and, as a rule, these lands are cultivated more intensively, giving two crops a year.

4. The Chazni Province as a whole possesses large potential resources of land suitable for irrigation development, but very limited surface water resources.

Of the normal run-off of the Ghazni river, $346 \mathrm{mill}^{3} \mathrm{~m}^{3}(83 \%)$ passes during the three spring months (Maroh-May), $1 \%$ in the summer and autumn months, and the remainder (16\%) during the winter months (November-February).

Orographically, the Nahar river is similar to the Chazni and its estimated normal annual run-off does not exceed $94 \mathrm{mill} . \mathrm{m}^{3}$.

5. If the run-offs of both rivers could be fully used for irrigation, and assuming that the present agricultural crops receive about $50 \%$ of the irrigation requirements (about 7,000 m $3 /$ ha.), the water resouroes of these rivers could ensure the Irrigation of not more than 65,000 hectares.

If 1 is is assumed that under the existing conditions out of the present total irrigated area of 65,800 hectares only 12,000 are irrigated by groundwater, then when the Chazni and Nahar rivers are fully put under control it would be possible, using surfaoe waters, to increase the total irrigated area by 11,200 hectares.

6. The run-offs of these two rivers cannot however be fully used, since the topogeological conditions limit the possibility of construoting economically justified storage dams in addition to the existing dam on the Ghazni river and one being built on the Jilga. 
7. Ground water is being used in considerable quantities in the Nahar valley, and to a less extent in the Wazi Khwa area, mainly from karezes but also by lift from wells. The yields of the karezes and wells range from 3 to 50 litres/seo.

8. The water from wells and karezes is applied scantily, The use of irrigation water from the rivers, especially in their upper reaches, lacks control and leaves muoh to be desired. Establishment of control over the distribution and use of the water now taken for irrigation from the rivers should therefore be the first step in developing irrigated agriculture.

9. Irrigation development in the province has already been started. At present the construction of the Sardeh dam is nearing completion, and the water stored in this reservoir will make it possible to increase the irrigated area by 8,000 to 13,000 hectares, depending on the composition of the crops grown. Until a new irrigation system is provided in this area, for not less than 5 years the water from this reservoir will partly be used for improvement of the water supply of the lands now under irrigation in the Ghazni valley, involving regulation and in part extension of the existing canals.

10. Rational use of additional supplies of water for irrigation will involve control works on the rivers as well as on the canals, to ensure effective intake and distribution. Any water projeot, especially one including a dam and reservoir, requires akilled looal and general management to maintain the works always in order, and to use every litre of water to the best advantage. This is particularly important in the Ghazni area, with its large resources of land and its very limited amounts of water.

11. However, management of water alone is not enough. Hithout the introduction of modern techniques of cultivation, production of orops cannot be expected to increase.

12. Therefore, in planning the economy of the country, and in particular its agrioultural development, priority should be given to training its own people, and primarily hydraulic engineers and agronomists, with a view to raising the standards of agricultural produotion by well-qualified management, in the various parts of the country including the Ghazni Province.

13. The results of the reconnalssance survey of hydrogeology in the Chazni province show that there are possibilities of developing irrigation further by the use of groundwater. However, before this can be done, detailed investigations and studies in this area must be made. These are inoluded in the UNSF Project referred to at the end of Chapter 29.

14. Bearing in mind that in the near future, after the completion of the groundwater studies, the problem of irrigation development in this part of the country based on the use of groundwater should have a high priority, it will be neceseary in connection with the hydrogeological study to carry out a broad programme of collectine relevant information and data. This should inolude:

a) The establishment of gauging stations in the Chazni and Nahar rivers. In studying the regimes of groundwaters, data on the run-offs of surface streams and the regimes of reservoirs are very important. At present there exists only one gauging station on the Chazni river, close to Bandi-Sultan reservoir, set up at the end of 1961. There are nn stations on the Nahar river, and no observations are made. 
b) Organization of a meteorological station in the middle Nahar vallej. In otudjing underground water regimes it is necessary to know all the meteorological factors and to trace their importance in the formation of the ground water regimes. It is necessary to have information on the precipitation, air temperature air humidities, eveporation, barometric pressures, soll temperature, and snow cover, oto.

To find out the conditions of replenishment of the aquifers an acourate record of all the precipitation (rainfall as well as snow) is particularly important.

In studjing artesian waters, it is necessary to consider the barometrio pressure in the areas whence they are replenished, even if they are remote from the weather station.

c) Organization of topographical surveys to locate all the sites of dams and observation points on the terrain and the map. This information will be needed also for the continuation of soll reclamation with the use of ground water. 
SECTION VI - ADRASKAND RIVER BASIN

CEAPTER 31 - DESCRIPIION OF BASTN

1. Ceneral Desoription of the Basin The Adraskand river has a total length of $480 \mathrm{Km}$. Its souroes are situated at altitude of about $3,000 \mathrm{~m}$. , and it flows into the Hamun-1-Sabari lake in the Seistan depression, at about $600 \mathrm{~m}$. The river has slopes of from 9 to $15 \mathrm{~m}$. per $\mathrm{Km}$. In the mountainous part, and on the average $3 \mathrm{~m}$. per $\mathrm{Km}$. In the lower valley, which is wide and flat.

The total catohment area has been estimated as 22,000 $\mathrm{Km}^{2}$. The watershed in places exceeds $3,000 \mathrm{~m}$. and elsewhere is as low as $1,000 \mathrm{~m}$. The catchment area situated above $2,000 \mathrm{~m}$. amounts to only $2,800 \mathrm{~km}^{2}$, or $13 \%$ of the total.

2. Climate As about $80 \%$ of the oatohment area of the river is situated in the zone of the plains and foothills, the basin of this river has a hot climate, with a high air temperature, little precipitation, and low humidities.

a) Air Temperature (Centigrado)

The mean monthly temperatures of January, the coldest month, and July, the hottest month, respectively are as follows:-

At a beight of $3,000 \mathrm{~m}$

At Adraskand vifiąo $(1350 \mathrm{~m}$ )

\begin{tabular}{rr}
$\frac{J a n u a r y}{}$ & $\frac{J u l y}{O} \mathrm{C}$ \\
\hline$-10.3^{\circ} \mathrm{C}$ & $27.0^{\circ} \mathrm{C}$ \\
$0.5^{\circ} \mathrm{C}$ & $27.3^{\circ} \mathrm{C}$ \\
$7.8^{\circ} \mathrm{C}$ & $36.0^{\circ} \mathrm{C}$
\end{tabular}

b) Precipitation

Little precipitation occurs in the Adraskand basin, only during the months of November to May, and mainly in the shape of rainfall. It is believed that on the average its different parts receive throughout the jear the following amounts:-

In the lower basin

In the Adraskand village area

In the highest parts of the basin
$50-100 \mathrm{~mm}$.

$150-200 \mathrm{~mm}$. up to $300 \mathrm{~mm}$. here precipitation also occurs as snow.

c) Evaporation

Eraporation from water ourfaces is estimated to be $2900 \mathrm{~mm}$. for the lower basin, and $1900 \mathrm{~mm}$. per year for the Adraskand village area. Volume III - Hydrology - gives information on mean monthly temperatures and evaporation values for each month for the Adraskand basin zone.

3. Vegetation and Animal life The Adraskand basin adjoins that of the Farah Rud. The physico-geographical and climatic conditions in these two basins are very similar and the flora and fauna of the Adraskand are analogous to those of the Farah Rud basin, desoribed in Chapter 12 of this Volume.

4. Population There are no official data on the population statistics. Howerer, judging by the information obtained by the tax inspection staff, it is believed that the population in the Adraskand basin may be about 80,000 , of whom about 7000 live in Shindand, the main city. 
The main ocoupations of the population are agriculture and animal husbandry; only up to $6 \%$ of the population are engaged in handicrafts, commerce and construotion work. The bulk of the population reside in the valleys of the Adrakand river and its tributaries, wherever conditions exist for irrigated agriculture. The mountainous part of the basin or in the deserts of the lower basin are virtually uninhabited.

5. Rosds and Communications Shindand ofty is connected with the rest of the country by the circular highway. (see Chapter 5) Shindand is also one of the two western terminals (the other being Herat) of the road which crosses the country from west to east and passes via Kabul to Pakistan. Local roads within the basin are very poorly developed and little sultable for motor transport, the majority of loads being carried by pack transport.

Shindand is connected by telegraph, radio and telephone with all the major towns in the country, but there are no telecommunications within the besin. 
CEAPIYR 32 - SOIIS AID EXISTINO LAND USE

1. Ceneral Information The soll survejs covered lands situated on both banks of the Adraskand river in the violnity of Shindand. The area survejed on the loft bank was two thirds, and that on the right bank was one third, of the whole.

The lands survejed lie at heights from 1450 to $1000 \mathrm{~m}$. above sea level.

2. Desoription of Solls On the basis of the data obtained from the field trips, five main s011 types were established. Their brief morphologloal descriptions are as follows:-

1) Brown desert soils; irrigated; light and medium loang, non-saline, alluvial; good drainage and satisfaotory

terrain.

11) Hydromorphio irrigated soils, partly saline, alluvial. Drainage and terrain are both satisfactory.

1i1) Reddish-brom desert soils, sandy loamy, skelotal, gravelly, highly permeable. The terrain is that of mountain slopes.

iv) Gravelly complex with Irrigated patches.

v) Cravel deposits.

Volume IV - Soils - gives a detailed description of typical soils in the surveyed part of the basin, together with chemical analysis data for each typical profile.

3. Land Resources The soil surveys resulted in the following division of the land into classes, according to the existing classifications

\begin{tabular}{|c|c|c|}
\hline Clase & Area in heotares & \% of total area \\
\hline $\begin{array}{c}\text { II } \\
\text { III } \\
\text { IV } \\
\mathbf{V} \\
\mathbf{V I}\end{array}$ & $\begin{array}{r}24,700 \\
5,000 \\
5,300 \\
100,000 \\
20,000 \\
155,000\end{array}$ & $\begin{array}{r}16 \\
3 \\
3 \\
65 \\
13 \\
100\end{array}$ \\
\hline
\end{tabular}

4. Land Use Under the Existing Conditions Under the present conditions, the use of eurveyed lands is classified in the following way:

a) Intensively cultivated lands and farmstead plots

b) Intermittently irrigated, dry farming, and fallow lands

c) Intermittently Irrigated, non-saline lands and non-irrigated saline lands, used as pastures

d) Lands eroded to various extents and gravelly lands, mostly used as pastures

$$
\begin{aligned}
& \text { 11,000 hectares } 7 \% \\
& 12,000 \quad \text { " } 8 \% \\
& 4,300 \quad \text { " } 3 \% \\
& \text { TOTAI } \frac{127,700}{155,000}=\frac{82 \%}{100 \%}
\end{aligned}
$$

The irrigated agrioulture is mainly based on the use of the waters of the Adraskand; only a very insignificant area is irrigated by groundwater with the help of karezes. 
Anidet the wide variety of agricultural orops, wheat is given the top priority, but in contrast with other basins, rioe also oocupies considerable areas.

The peasants have amall holdings, and only very fou farmsteads have more than one heotare of irrigated land. The plots are anall, rarely excoeding 0.1 heotares, but are very well levelled. Crop rotations are not rigld, the peasants following traditional practices.

Mineral fertilizar are not employed, but earth manure and dung are applied annually on Intoneively oultivated plote.

The sparsoness of irrigated plots is a oharaoteristic feature of the Shindand valley irrigation. One of the main reasons for such a peculiarity is the undulating terrain with depresaions which, in the absence of drainage canals, grow saline. The other, and still more important, reason is the lack of control over the distribution and use of irrigation water. 
CHAPTHR 33 - HIDROLOCI

1. Initial Deta The appraisal of the water resources of the Adraskand basin is based on the analogous date for the Farah Rud river and on short-term observations carried out at two gauging stations in the Adraskand valley, set up by this Project in February 1963.

2. River Regime The rather low elevation of the catohment area of the Adraskand basin, the limited amount of seasonal snow, and the occurrence of rainfall during the period from March to May, cause several short-lived floods, whose maximum disoharges at the Adraskand and Bud-1-Chaz confluence may rise to sereral hundred $\mathrm{m} / \mathrm{sec}$.

During the summer and almost throughout the entire autumn, when precipitation is nil in the basin, the river is fed by groundwater. During this time, disoharges at Adraskand village range from 0.5 to $1.5 \mathrm{~m} / \mathrm{sec}$. The flow in the oummer and autumn period is fully consumed for irrigation and the river dries up till December.

3. Normal Annual Run-off The appraisal of the normal annual run-off of the Adraskand river has been based on the established relationship between the mean runoff modulus and the average elevation of the river basins in the south-western Afghanistan. It was assumed, reasonably, that the run-off formation in the upper Adraskand is similar to that in the Farah Rud.

\section{TABLE 79}

\section{ADRASKAND AND BUD-I-GHAZ - ESTIMATED NORMAL ANMUAL RUN-OFFS}

Nane of River and Station

1. Adraskand at gauging station near Adraskand villago

2. Bud-i-Chaz at gauging station

3. Adraskand below confluenoe with Rud-iGhaz
Mean DLsoharge $\mathrm{m}^{3} / \mathrm{se0}$. Normal Year Year of $75 \%$ Probab1lity *
Annual Bun-off Mill. $\mathrm{m}^{3}$ Formal Year Year of $75 \%$ Probability *
$4 \cdot 3$
2.7
135
85
$4 \cdot 3$
2.7
135
85
$8.6 \quad 5.4$
270
170

* Probability - Seo Glossary.

4. Bun-off Distribution Within the Year There was established the following approximate distribution of the run-off vithin the year, in $\%$ from the annual runoff, at the gauging stations on the Adraskand and 1ts tributary Rud-i-Ghaz: 
TABLE 80

ADRASKAND AID RUD-I-GAZ - RUI-OFF DISTRIBUIION WITHIN THE TEAR

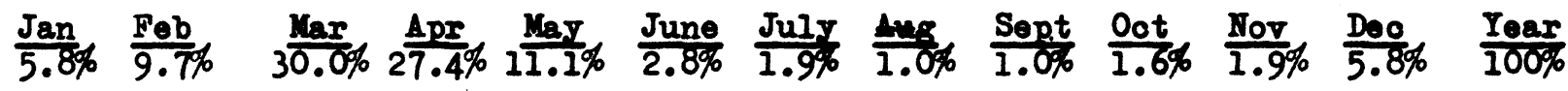

The seasonal distribution of the river run-off in $\%$ from the anmual run-off is the followings

$$
\begin{array}{ll}
\text { Spring (Maroh-May) } & 68.5 \% \\
\text { Summer and Autumn (June-November) } & 10.2 \% \\
\text { Winter (December-February) } & 21.3 \%
\end{array}
$$

All the summer and autumn run-off, and probably all the winter run-off, is fully taken up for irrigation. However, out of the spring (flood) run-off, amounting to $170 \times 68.5 \%=116 \mathrm{mill} . \mathrm{m}^{3}$ at $75 \%$ probability, not more than 50\%, that is $50-60$ mill.m 3 , is used. The remaining $50 \%$ could be used only if the run-off were controlled by reservo1rs.

5. Fluctuations of Annusl Bun-off, Maximum and Minimum Discharses and Sediment Discharge . The values of the annual run-off fluctuations, maximum and minimum discharges, at various probabilities, and also the sediment discharge of the Adraskand and its tributary Bud-1-Chaz, and also the sediment disoharge of the Adraskand are given in Volume III - HydrologJ. 
1. General It was noted in Chapter 32 that in the survejed basin area there are 29,700 hectares of Classes II and III lands quite suitable for 1rrigation. Out of these lands only 11,000 hectares, or about 40\%, are now annually 1rrigated, because of the lack of water for irrigation, the remaining 60\%, mostly fallow lands, being at present partially used for dry farming orope whioh give very lor ylelds.

Of the total annual run-off, $54 \mathrm{mill} . \mathrm{m}^{3}$, or $31.5 \%$, oocurring in the summer, autumn and winter, are already completely used for Irrigatign. As already ahorn in Chapter 33, of the mun-off in the spring period, $116 \mathrm{mil1.m}$, not more than $50 \% 18$ now used, that 18 up to $58 \mathrm{mill} \cdot \mathrm{m}^{3}$. The other $50 \%$ oould be used only with water control in reservolrs.

2. Potential Reservoirs To ascertain the possibilities for irrigation development in the Adraskand basin, gome topo-geologioal studies rere made to discover potential dam sites for reservolrs.

On 1850,000 maps of the mountainous part of the Adraskand and 1ts tributaries the Rud-1-Ghaz and the Kuland, two potential sites on the Rud-i-Ghaz were located on paper, of which one was far up its course and had a very limited catohment. It was only possible to visit the lower site. It was found that here the Rud-i-Chaz has relatively steep slopes up to $15 \mathrm{~m}$. per Kllometre, and narror gorges, and that because of geological conditions the helght of the dam could not exoeed $30 \mathrm{~m}$. It was estimated that this could provide a reservoly with a capacity of only $15 \mathrm{mill}^{\mathrm{i}} \mathrm{m}^{3}$, and that this would silt up in about ten Jears. This site cannot be recommended.

The southern tributary of the Adraskand (Wuland), is even less promising, judging by the $1: 50,000$ maps, than the Rud-i-Chaz catohment.

The Iimited time arailable to the Project did not permit of a more extensive survey of the Adraskand dam sites. The possibilities of the lower valley, particularly of the gorge a short distance above Jige Sarai, remain to be examined. But, considering the water resources that still remain unused in this area, onls about $60 \mathrm{mill} \cdot \mathrm{m}^{3}$, and the preliminary topo-geological investigations made, it can be concluded that the prospects of irrigation development in the Adraskand basin are Iimited, and that compared with the Hari Rud and the Farah Bud, between whioh Adraskand is situated, this basin will not play any substantial role in the development of agriculture and economy as a whole of this part of the country. 
The soll ourvegs have proved that there are available in the Shindand valley free land resources sultable for irrigation.

The lana olaseifioation has show that in the ourreyed part of the Adraskand basin lands of Classes II and III amount to 29,700 beotares. These are lands that need only water. For irrigation development of these lands, however, the construotion of reservoirs will be required, einoe under the present conditions, that is without water control, only 11,000 heotares, or around $40 \%$, oan be provided with irrigation water.

As already mentioned, out of the $116 \mathrm{~m} 111 . \mathrm{m}^{3}$ of the spring run-off, only up to 58 mill.m is at present used. Consequently, unuged water resouroes in the Adraskand basin are equal approximatels to $58 \mathrm{mill} . \mathrm{m}^{3}$.

With the present range of agricultural orops and the irrigation regime, the gross irrigation requirement will bes $10,200 \mathrm{~m} 3 /$ bectare.

In these conditions, and using the water resources of the Adraskand banin in full, potential irrigation development in this area can cover an additional 5,700 heotares.

Construotion of a reservoir will be required to make use of this land potential in the Adraskand basin. 
CHAPTER 36 - CONCLUSIONS AND RECOMMENDATIONS

1. The Adraskand basin has land resources, but very limited water supply. Out of the 29,700 hectares of Classes II and III lands quite suitable for Irrigation, and 5,300 hecatres of Class IV lands conditionally suitable, only 11,000 hectares are now annually irrigated. Water is necessary for irrigation development on the remaining 18,700 heotares (Classes II and III lands). However, out of the total annual run-off at $75 \%$ probability, only about $58 \mathrm{mill} . \mathrm{m} 3$ of unused water is available in the Adraskand basin. Making use of all this water, irrigation development in the basin oould be expanded only by 4000-6000 heotares. A reservoir with an available storage of up to $60 \mathrm{mill} . \mathrm{m}^{3}$ would be required, which would control the Adraskand vater resources completely.

2. The Adraskand basin is situated botween the Hari Rud and Farah Rud basins. These two basins have large land and water resources potential (see Sections II and III). Utilization of this potential will be given a top priority by the Government of Afghanistan in the economic development of the country's west and south-west parts. Therefore, in the Adraskand basin with its free land resources and very limited supply of water, irrigation development must be contemplated as a more distant goal, that is after the Farah and Herat lands are developed.

3. The existing irrigation system in the Shindand valley is composed of numerous canals of different discharge capacities (from $50 \mathrm{l} / \mathrm{sec}$. to $1.5 \mathrm{~m} / \mathrm{sec}$.) w1th independent intakes in the river, which are liable to frequent destruction by floods. Measures of a general nature should be begun as soon as possible in the Adraskand basin to improve the system of water intake, distribution and use. For this, it will be necessary to combine the various headworks and feeder canals, and to equip them with regulating, measuring and other control equipment. It might also be necessary to create a drainage system for those areas having poor natural drainage, with a view to reducing salinization and saving the land from further deterioration. Finally, to lessen the harmful influence of the strong summer winds on orop productivity, and to avoid soil erosion, a start should be made in planting shelter belts of useful. decorative or fruit-bearing trees and shrubs. 
GRAPTPR 37 - BAKMA VATIEI \& POSSIBIITIIES OF IRRICAMIOA

In the course of implementation of this project the Minister of Agriculture of Afghanistan asked for opinions as to the possibility of irrigation of the Bakra valley.

Because of the lack of means and time, this chapter gives a strictly prelininary foreoset of the possibilities of irrigating these lands, whose studs was not inoluded in the plan of operations of the projeot. This foreoset is based mostly on aerial photographs and contour maps.

The Bakwa valley is situated between the Farah Bud and Khash Bud rivers. Visual reconnalssances of a part of the lands in this valley suggested that they might be suitable for Irrigation; some soll survey has been done under the Helmand Valley Authority, but the results are not known. Irrigation by aurface waters is possible from the Farah Bud and Khash Rud rivers.

The Farah Hud has free water resources during spring floods; however, to use this water for irrigation of the Bakra lands a reservoir, and a very long tunnel under the Siyakh-Band-Koh mountains would be required. This would be very expensive and not justified oconomioally.

The possibility exdsts of using the spring flood waters on the Khash Rud. With this in view, the engineer-geologist, when flying from Herat to Kandahar, located a potential dam site on the Khash Rud river. From aerial photographs and contour maps this site is looated 38 air kilometres north-east of Dilaram, at approximately $32^{\circ} 22^{\prime}$ II and $63^{\circ} 45^{\prime} \mathrm{E}$. Coologioally, this dan alto does not seem to be very complicated. The topographioal conditions would appear to allow of a dam about $50-60 \mathrm{~m}$. high, forming a reservolr of 50-100 mill.m capaotty. The site has not been examined on the ground.

Such is very striotly preliminary infornation on the problem. The prospects at present do not appear promising. To obtain more detailed information it is neoessary to carry out a serles of reconnaissance survejs and investigations, as was done in the Hari hud and Farah thud basins. Pedological, hydrological, goologioal and topographical survejs would be required on which it would be possible to find outs

a) Land resouroes, acoording to the land classes;

b) Water resources and their hydrological characteristios;

c) Suitability of the dam sites and reservoir basihs, in respeot of geological and topographical conditions;

d) Eoonomio justification and effectiveness of irrigation development in the Bakwa vallej.

It should be noted that the Bakwa valley is inoluded in the Special Fund Project for the study of hydro-geological conditions, now being undertaken. 
SECPION VII - COHCLUSIOHS

\section{CHAPTER 38 - IRRTCATION DEVELOPIEITT IN THS SURVETED BASTHS}

1. Soope of the Projeot The areas covered by the Projeot 110 within six river basins: Hari Rud, Adraskand, Farah Rud, Upper Kabul, Ghazni-Nahar, and the Hazikhwa area (Katawaz). In each basin investigations were made of topography, geolosy, soils, and hydrology, on the basis of whioh preliminary assesements were prepared of the potentialities of irrigation development. Sohemes for auch development were worked out for three of these basins, Harl Bud, Farah Bud, and Jpper Kabul, as being those with the best prospeots, and as harlng considerable resources of both land and water at present unused.

2. Priority of Development It is reconmended that the order of priority of irrigation developwent in the three basins should be as follows:-

(1) Herat Valler On a total net area of 131,000 hectares, of which 76,000 hectares would be additional to the area now irrigated. The soheme would provide the possibility of hydro-electrical development to a total installed capacity of $85,500 \mathrm{Kw}$. In five stations. Four storage dams would ultimately be required.

(ii) Upper Kabul On a total net area of 140,700 hectares, of which 44,800 hectares would be additional to the area now irrigated. Two storage dams would be required. No hydro-electrio power could be economically developed.

(1ii) Farah Rud On a total net area of 59,200 hectares, of which 34,100 hectares would be additional to the area now irrigated. One storage dam would be required. The soheme would provide the possibility of hydro-eloctrio development in one station with an installed capacity of $24,000 \mathrm{Kw}$.

It appears particularly desirable to prepare a detailed project for irrigation development in the Herat valley, with a vier to beginning actual construction there in the near future.

3. Considerations Affecting Irrigetion Develorment In Afghanistan, where annual rainfall in many parts does not exoeed $200 \mathrm{~mm}$. and over many months of the year the climate is very dry, effective agriculture is impossible without irrigation. The regulation of the run-off of the rivers, the improvement and control of water supply to existing areas of irrigation, and the extension of irrigation to new areas will all contribute to the strengthening of the economy of the country. The adoption of improved teohniques of cultivation will raise jields, and the introduction of new and more valuable crops will in addition provide raw materials for industries and fodder for a more productive livestook industry. This will result in a more flourishing agricultural industry and increased purchasing power, which in turn will make possible increased revenue for Government.

4. Further Survere and Investigations Required For the preparation of definite projeots in the valleys of Herat, Upper Kabul, and Farah, a number of surveys and investigations will be required, with the folloring objectives:- 
(a) To determine in all requisite detall the extent and location of the lands to be developed, the conditions of water supply and the methods of watering?

(b) To design and lay out the canal and drainage systems, dams, and other works required, to asoertain the quantities of rork involved, and to decide on the methods, organisation and priorities of construotion:

(o) To asoertain the quantities of power, plant and equipment, and materials required for the works proposed, and the most economio sources from which to obtain theses

(d) To determine the costs of construction and of operation, and the costs and values of agricultural production:

(e) To prepare economio appraisels of the developments proposed.

To achieve these objects, the following surveys will be requireds-

(1) Topographical Survers with triangulation and preoise levelling, and the preparation of olose-contoured maps at 1 : 10,000 soale. These will be used for designing the layout of irrigation systems.

(ii) Soil Survers on a sufficiently detailed standard, to ascertain how much reclamation will be required, with studies of soil and water properties, vertical salt distribution eto. and maps on a soale $1: 25,000$.

(11i) Appraisals of geologioal, hydro-geological and engineering conditions. These will make it possible to plan rational systems of Irrigation and of drainage, to permit leaching of saline lands.

(iv) Erdrological Surverg, including the collection and processing of data of river flows and their variations within the year and in different years, and of the flows taken into existing irrigation canals. Data should also be colleoted of the salts and the sediment in irrigation waters. The flow characteristics of dry stream beds crossing or entering the irrigable areas should be ascertained.

(v) Teohniosl Data of Construotion and Operation are necessary for the planning of development. They will include data on the availability of building materials, equipment, porer, water, labour, and roads.

(vi) Eoonomio Data. To assess the roonomic justification of each scheme, its costs of construction and operation, and the gross and net value of 1ts expected production are required, to enable its potentialities to be appraised, in relation to the economy of the region concerned, and of the country as a whole.

5. Land and Nater Eoonomy and Use Nater economy, in the proper sense of the expression, does not exist in the country at present, except within the sphere of the Helmand Valley Authority. Elsewhere there are separate and self-contained oanals without intake control works, constructed by local people to suit local conditions. 
At present, when the country's agriculture is beginning to be based on a national plan providing for a rational development of all branohes of the economy, it is essential to consider questions of specialisation in particular areas, acoording to their conditions. In particular, the growing national tertile and argar industries will require local supplies of raw materials. Where cotton and sugar beet can be grown on irrigated areas in place of grain crops, significant changes in water requirements will result. The planned use of water will have to become more independent of the natural regime of the sources of supply, 1.e. the rivers.

In the extension of irrigated agriculture on new lands, the aim should be to establish larger farms, based on mechanization. The operation of agricultural machinery on tiny 1rrigated plots would be very difficult and quite uhoconomic. On the lands now irrigated, the whole system, from field plots to canals, should be replanned and reconstruoted, to permit of mechanised oultivation, to reduce the work involved, and to ensure the more effective use of water.

Planning, both for new development and for reconstruction, should provide for higher percentages of land under orops, for improved conditions of reclamation, for protection from winds by tree belts, and for the planting of forest plots for timber, and orohards.

6. Irrigation Systems and Works It is necossary to plan for combining the remodelled extsting irrigated areas with the new areas to be developed, so as to create efficient systems of irrigation, suited to mechanised cultivation. To combine the separate irrigation ahannels in existing areas into proper systems with stable conditions at the intakes, it will be necessary to construct larger main canals, or to enlarge existing canals, as may be most sultable in each oase. This will result in fewer intake points, shorter main oanals and non-irrigating reaches, and thus in diminished seepage losses and increased areas under orop.

The development of irrigation systems and works may be achieved in three stages a.8 follows:-

(i) The establishment of main canals with controlled headworks on rivers, without weirss

(11) The addition of welrs or barrages across the rivers to raise the water levels at low stagess

(1i1) The regulation of run-off by storage reservoirs.

For the site of a canal headworks, a stable section of the river channel should be selected. To reduce the amounts of sediment taken into the canal, the intake work 1s usually sited on a concave curve of the bank. Where the river bed is irregular or the geological conditions are unfavourable, special measures may be necessary to ensure the safety of the headworks, e.8. by regulating structures in the river channel, such as a weir, or by proteotion on the bank. In stage (1), such works may be of a temporary nature, using local materials, including stone, timber, earthwood, or even brushwood: they will require regular maintenance or even reconstruction, after flood damage. In designing and constructing them, full use may be made of the local people's long experience, ingenuity and technical skill.

The head regulators of main canals, bullt of masonry, concrete, or reinforced concrete, will be fitted with gates and lifting gear, which will make it possible to increase considerably the discharge capacities of the canals, without difficulties arising from uncontrollod inflows, as at present. 
To reduce seepage losses from canals, they should where possible be located in soils of low permeability; sealing should be done by the deposit of fine silt; where required, canals can be lined with masonry, concrete, or reinforced conorete. Lining or protection may also be required to guard against erosion by excessove velooities of flow, or, where slopes are very steep, drop-falls or chutes may be required, and these may provide sites for hjdro-electrio porer stations.

The reconstruotion of irrigation systens should not be limited to the headworks and the main canals. It should also extend to the distributary systems, field ohannels, and plots. These, developed piecomeal in the present conditions of land ownership and use, are quite unsuitable for modern methods of irrigation, and in particular for mechanisod agriculture. They will all have to be replanned and reoonstruoted, including all necessary levelling of land. The present inferior method of irrigation by flooding ahould be replaced wherever poselble by some better method such as furrow irrigation, partioularly for arable orops. Drainage syatems should be provided, to prevent waterlogging and salinization of lands, and where these have already occurred to make poseible reclamation by leaching, resulting in inoreased yields of crops and extension of irrigated areas. Complete reconstruotion will take many jears; the smaller takk can be taokled first, and the larger takke later, as materials and equipment become available, and as more qualified onglneers, agronomists, and other techniclans are trained. Solution of these problems will involve consideration of the system of land-tenure.

\section{Other Keacures}

(1) Underfround Water Supplies. Further hjdro-geologlcal investigations are very desirable, and have already been arranged for in certain areas under the new Speoial Fund Croundwater Project (see Chapter 2 Seotion 15) In some areas, at present waterless, it is not impossible that artesian supplies of water may be found, or at least sub-artesian supplies, which oan be made available by lift, using wind or mechanioal power. Suoh supplies mas help in providing water and additional foddor in pastoral areas.

(11) Local Storage of Surface Nater. Bven in areas of relatively low rainfall, much can be done by simple measures to catoh and store rainfall when it oocurs in amall reservolrs. By the extension of interooptor ohannels, and by forming such reservoirs with considerable depths and steep sides, storage can be improved and evaporation losses reduoed.

(iii) Noohanisation. In exeouting the necessary works, both of construction and maintenanoe, large and anall, the use of nechanical equipment and plant will greatly help to peed up the work and inorease its effloienoy, and in manj oases to reduce its cost.

(iv) Animal Husbandry. As already mentioned, improved land and water use will contribute to the development of better animal husbandry by the provision of assured cupplies of foddor and water.

8. Recommendations on the Nanagement of Land and Nater Use In the light of the considerations set out in the previous paragraphs of thischapter, it is orident that: -

(a) The further development of africulture, the core of Afghanistan's coonomy, is possible only by irrigations 
(b) The increase of the areas under irrigation will, in general, be limited by the amounts of water that oan be made available, rather than by the extent of land wich are, or can be made, suitables

(0) In viow of this, the control and regulation of river flows by storage in reservoirs should be undertaken so far as economically justifiables

(d) At the same time, it is essential to encure that the amounts of water made available are always used to the best possible advantage. In most of the existing irrigated areas this can only be achieved by reconstruotion and remodelling, with coordinated control of water supplies and use:

(e) Every year more and more hydraulic works and struotures and canal systems, large and small, will contimue to come into operation in different parts of the country.

The proper upkeep and unfailing and effective operation of the inoreasing mumber of state-owned schemes of irrigation oan only be satiafactorily ensured by the establishment of a single Government organization which can deal with the varied problems involved. It is suggested therefore that there should be set up, in close connection with the Ministry of Agriculture, an Authority or Department of Land and Water Use, with wide terms of reference. The problems involved in this, and the recommendations made, are discussed in Appendix No.II"Management of Land and Water Use". Here it will suffice to summarise the main points to be considered as follows: -

\section{(i) Terms of Reference. These may include:}

1. The survey, study, registration and inventory of land and water resources, in individual sohemes, existing and potential:

2. All technical aspects of soil surveys, irrigation agronomy, water distribution and field applioation, drainage, and land reclamation, etc., as well as river control, the regulation of reservoirs, and the measuremont of water flows and usages

3. The operation and maintenance of canal and drainage systems, regulators, dams, pumping stations, buildings, communications, and all other works necessary to irrigation, drainage, and river control:

4. Rules and Regulations relating to all these matters.

(ii) Organisation. It is proposed that this Authority or Department should include an adequate staff of speoialists in the various branches of its work, but particularly in irrigation and drainage practice and hydraulic engineering, posted as requisite both at headquarters in Kabul and in provinoial centres where irrigation development exists and will expand. It appears essential that the Authority should be both expert, in order to advise, and exeoutive, in order to carry out development and to mpervise the applioation of rules and regulations. 
The oreation and entablimbent of woh an Authority, and 1ts relationship to other authorities and departmonts within the administrative framorork of Covernment, involve questions of poliog which are outelde the scope of this Roport, and therefore are not further discussed here. The inportanoe of this whole matter is howerer most strongly empharized. It is of little advantage to construct oven the best deaigned works and yoteme of irrigation if they are not operated and maintained with high efficienoy. 


\section{APPEHIDIX 1}

\section{AMEMTED PLAN OF OPERATION}

UNITED NATIONS SPECIAL FUND PROJECT IIN AFGHANISTAN

SURVEY OF LAND AND WATER RESOURCES

Special Fund Allocation

US $\$ 799,550$

$$
\begin{aligned}
& \text { (including): (a) } \begin{array}{l}
\text { Special Fund Contribution } \\
\text { (including Agency overhead } \\
\text { costs) }
\end{array} \\
& \text { US } \$ 716,940 \\
& \begin{array}{ll}
\text { (b) Government's payment towards } \\
\text { local operating costs }
\end{array} \text { US } 82,610
\end{aligned}
$$

Government Counterpart Contribution
(a) in kind
Afghanis 11,883,833
Equiv. US\$ 247,580
(b) in cash
US\$ 21,117

Duration:

Erocuting Agenoy:

Cooperating Government Agency:
$3^{1 / 2}$ years

The Food and Agriculture Organization of the U.N.

Water and Soil Survey Authority Royal Government of Afghanistan

For the purpose of the Survey of Land and Water Resources, to be undertaken by the Food and Agriculture Organization of the United Nations, acting as Executing Agenoy for the Special Fund, this Plan of Operation supersedes the Plan of Operation and its amendments signed on 29 June 1960 providing for the (i) Survey of Land and Water Resources and (ii) establishment of an Agricultural Station. This amended Plan of Operation concerns exclusively the Survey of Land and Water Resources and liquidates the Agrioultural Station part of the project inoluded in the Plan of Operation effective since 15 August 1960 and shall be the Plan of Operation provided for in Article I, paragraph 2 of the Agreement signed on 21 February 1960 by the Government of Afghanistan and the United Nations Special Fund.

This Plan of Operation covers exclusively expenditure relating to the Survey of Land and Water Resources. Bxpenditures from the Special Fund Allocation already incurred for the Agricultural station part of the project as described in the Plan of Operation signed on 29 June 1960 will be absorbed by the Speoial Fund by mutual agreement between the Food and Agriculture Organization and the Special Fund. 


\section{PURPOSE $\triangle M D$ DISCRIPTION OF THE PROJBCT}

\section{A. Purpose of the Project}

1. To provide information on the comparative land and water potential of the river basins including Farah Rud, Adraokand (Harut), Ghasni (including Katawas) Kabul river (including Panjaher, Ghorband, Shakardara and other tributaries of Kabul river up to gorge of Sarobi) and Logar river with the view to otimulate agrioultural and general economic development.

\section{B. The Project}

2. The project will compise a land and water resources survey which will include the river baeine nanod above. The survey will provide ultimately a land and water resources inventory obtained throughs

(i) Study and ourvey of the important existing irrigation canals and oystens, in relation to present land and water use, and with a view to future improvenants.

(ii) Flow meacuroments on rivers and existing canels for the assessment of their development potential. Study of climate and meteorology.

i) Survey of possible storage sites on the rivers mentioned above, with a view to improving their water potential, including the necessary topography, geology, and water management planning.

(iv) Reconnaissance soil survey and land classification in the river basins mentioned, with special omphasis on irrigation farming, and within the commanded areas as defined by topographic ourveye.

(v) A land use study in each basin, besed on the above stated investigations and surveys.

3. The survey will also includes

(i) Training the counterparts in all aspects of the project.

(ii) Surveys carried out by other agencies will be taken into oonsideration in the making of the program, and their reeulte will be made use of in the Project Report.

(iii) Such aerial photography, photomosaics, and oontour mape, as are available to the team from the Ministry of Minen, or Cartographic Institute, or other sources will be used in the work of the survey.

4. A team of 15 experts is required to carry out these various aspecte of the land and rater resources survey. They will work with the Afghan counterparts, who will be ongineers, soils technicians, and agronomists and who, after the speoial Fund project has onded, will continue and expand the survey. In partioular thoy will operate the hydrological tation whioh hare been establishod with equipmont supplied by the U.I. Special Fund. The findings of the water and soil ourvey 
will be presented in the form of a preliminary development plan, and this will include:-

(i) Classification of the soils in the seleoted river basins with speoial referenoe to their suitability for irrigation farming, in the areas commanded by the rivers.

(ii) An appraisal of the water potential of each river basin ourvejed.

(iii) 1 general description of the present land use pattern, and tentative proposals for future land use, in the areas where irrigation is considered to be probable, after the full water potential of the rivers has been made available.

(iv) A general assessment of the power potential of the rivers, taking into account the proposed pattern of release of water for irrigation should form part of the water management plan.

(v) Proposals for the improvement of the existing irrigation systems.

(vi) A tentative plan for water-management on river basin scale taking into consideration the possibility of storage of flood water.

\section{WORK PLAN}

A. Participation and Contribution of the U.N. Special Fund

5. The Speoial Fund will provide the following through the Executing Agency:

(a) Pereonnel Services

1 Water Development Engineer (Project Manager)

1 Senior Engineer

1 Hydrologist

1 Hydrometrist

2 Survey Engineers

1 Engineering Geologist

2 Soil Surveyors

2 Soil Chemists

1 Land Use Planning Expert

1 Hydraulic Engineer

1 Irrigation Survey Engineer

Short-term consultants

1 Administrative officer

37 months

19 "

39 "

41 "

$61 "$

29 n

56 "

40 "

7 "

12 "

$12 " 1$

$4 "$

18

375 months 
(b) Fellowships

2 in water development engineering/irrigation engineering

2 in hydrology

2 in soil survey and soil chemistry

2 yoars

211

6 years

Fellowships awarded under this Plan of Operation shall be administered in accordance with the fellowship regulations of the krecuting Agenoy. The duration of each fellowship may be changed provided the total of aix fellowship-years is not exceeded.

(c) Equipment and Supplies

(i) Topographio equipment such as levels, theodolites, altimeters, planetables, telemeters, stereotope, staves, chains, etc.

(ii) Hydrometric devices such as current meters, cables, trollejs, limnigraphs.

(iii) Soil laboratory and field equipment such as conductivity bridge, pH meter flame photometer, and other items of equipment including chemicals.

(iv) Camp equipment (camp beds, tables, ohairs, tents, etc.)

(v) Jeep type vehicles, trucks, station wagons.

(vi) Equipment and material for preparation and printing of maps and reports.

(vii) Sundry purchases.

(viii) Drilling rigs.

The total cost of equipment should not exceed US\$141,200.

(d) Miscellaneous

Miscellaneous expenses including the cost of one vehicle for the transportation of personnel and secretarial assistance, contingencies, postal and cable charges for a total of US\$ 19,000 .

B. Participation and Contribution of the Government

6. (a) Personnel

1 Co-Manager, Hydraulic Ingineer

10 Civil Bngineers, Technioians or Surveyors

6 Soils Teohnioians

2 Agrioultural Bngineers or Agronomists

4 Draftamen or Photographers

2 Conetruction Foremen

18 Drivers

2 Vehiole Koohanios 
1 Administrative Assistant

1 Stores Manager

1 Accounts Clerk

1 Correspondence Clerk/Typist

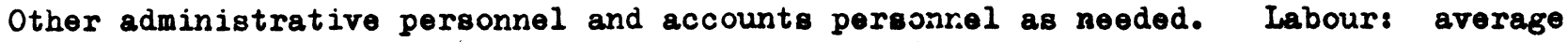
of 30 men employed on survey plus construction of gauges.

(b) Equipment and Supplies

(i) Aorial photographs and maps

(ii) Fuel and lubricants for the vehicles oupplied by the Brecuting Agenoy

(iii) Construction of river gauging stations, and moteorologioal tations

(iv) Kiscellaneous small supplies

(v) Tro venioles for local transport of counterpart ataff, together with the fuel and lubricants for the same

\section{(c) Servioes}

(i) Supply of insurable small aircraft for reconnaissance flights.

(ii) Soils laborstory facilitios and installation as required for oil and water analyses connected with the soil survey and hydrology.

(iii) Offices for international and Afghan personnel and storage pace for equipment.

(iv) Field accommodation for Afghan personnel and labour, including locally available camp equipment.

(v) Repair and maintenance of vehicles supplied by the U.N. Special Fund.

(d) Miscellaneous and Contingencies

7. Cost of Freight and Equipment

The Government will meet the freight costs including clearance charges of all equipment supplied by the Executine Agency, from the point of entry into the country to the project area. These costs will include those of transport, insurance, handling and storage within the country, and other related expenses. In the special case of the equipment for the soils laboratory, the Executing Agency will deliver this at Frankfurt, and the Government will pay all further costs of transport by the Ariana air line from Frankfurt to Kabul.

\section{Local Operating Costs}

In accordance with Article V, paragraph 1 (a) to (d) of the Agreement referred to in the preamble to this Plan of Operation, excepting the cost within the country for the transportation of project supplies and equipment which is a counterpart contribution, the Government shall pay to the Special fund in local ourrency the equivalent of US $\$ 82,610$, towards local operating costs. This amount represents 15 per oent of the total estimated cost to the Special Furd of foreign project personnel. Payments towards this amount have been deposited, or are due to be deposited, by the Government in local currency to the credit of the Special Fund account No. 9539 with Pashtany Tojaraty Bank in Kabul, as follows:

Equivalent of US\$18,577 deposited on 14 August 1960

Equivalent of US\$ 36,871 deposited on 22 February 1961

Equivalent of US\$21,691 deposited on 26 March 1962

Equivalent of US $\$ 5,471$ to be deposited on 1 January 1964. 
Pursuant to the provisions of the Explanatory Note to Amendment I (Rev. 1) to the Plan of Operation signed on 29 June, 1960, now superseded as provided in the preamble to this Amended Plan of Operation, the rate of exchange used as the basis of calculation of the above first three equivalent amounts, has been a rate fixed by the United Nation Controller in consultation and agreement with the exchange control authorities of the Government of Afghanistan. Similar procedure shall be followed in calculating the local currency equivalent of the fourth payment.

\section{Government Contribution in Cash}

(i) The cost of spare parts for the maintenance of vehicles, occasional hire of additional vehicles where necessary, and expenses for miscellaneous and contingencies, will be met by the Government in cash.

(ii) The dates and amounts of payments towards the Government Cash Contribution are as follows:

14 August 1960
22 February 1961
26 Maroh 1962
21 Maroh 1963
323,500 Afghanis

323,500 Afghanis

183,317 Afghanis

183,317 Afghanis

$1,013,634$ Afghanis

\section{Sequence of Operations}

10. The Executing Afency will commence operation of the Project upon written authorization to do so from the Maraging Director of the Special Fund.

11. Immediately after the signature of the Plan of Operation by the Government, the Executing Agency, and the Special Fund, the Brecuting Agency shall undertake recruitment of the experts. At the same time the Government shall appoint the Co-Manager, acceptable to the Executing Agenoy.

12. Upon the arrival of the Project Manager, the Government shall supply to him aerial photographs and photo moseics covering. the areas where the resources survey will first be carried out.

13. A general plan of survey operations shall be drawn up by the Project Manager of the survey, in consultation with the Co-Manager and the project committee, not later than six weeks after the arrival of the Project Manager in the country or the appointment of the Co-Manager, whichever is the later. For this purpose the Project Manager, the team members concerned, and the Co-Manager, should undertake reconnaissance flights over the river basins selected for the survey. The general plan should include a list of the river basins to be included in the survey, the sequence in which the different areas should be surveyed, and a general description of the operations. Not later than two months after the submission of this general plan, a more detailed plan of work should be submitted, covering the first year of operation. In this plan, staffing, equipment, transport and labour requirements should be given for each of the six groups. (Hydrology, topography, soils, geology irrigation and land use). The requirements should be given in sufficient detail to ensure the timely supply of materials and equipment, transport and lodging. 
14. Similar detailed plans should be drawn up not later than two monthe before the end of each year, for the coming year.

15. In working out the detailed plans due consideration shall be paid to olimatic conditions in the various river besins.

16. The local authorities shall be kept informed about the movements of the teams, and their requirements in accommodation, suides, horses, and local materials.

17. The Project Manager in consultation with the Co-Manager should prepare at the earliest possible date a detailed list of equipment, materials, eto. required for the project. The list of foreign equipment, materials, to be supplied by the Breouting Agenoy shall be sent to the Executing Afency which shall proceed immediately with the placing of orders.

18. The Project Manager and the Co-Manager shall proceed jointly with the selection of counterpart personnel and of administrative personnel, as provided in this Plan of Operation.

\section{Organization}

19. Overall responsibility for the organization and execution of the project rests with the Bxecuting Agenoy, who will plan and direct operations through the Project Manager (a water development engineer) who will be selected and appointed by the Exocuting Agency in consultation with the Government.

20. The Government will appoint a Co-Kanager acceptable to the Executing Agency. He will be a hydraulic engineer and will cooperate with the Project Manager towards a euccessful performance of the project. He will seleot and appoint the counterpart personnel, in consultation with the Project Manager, and administer them in respect of pay and service conditions. Through him the Afghan staff will receive their general directives regarding their work. He will give advice and assistance to the Project Manager on matters of local conditions and procedures. He will facilitate contacts with Government agencies, and arrange for the release to the Project Manager and team members of information held by such agencies.

21. As it is envisaged that on completion of the project the Co-Manager will be entrusted by the Government with the continuation of the soil and water resources survey, the Co-Manager shall have the right to study all aspects of the work, about all of which the Project Manager shall keep him informed, and he may bring to the notice of the Project Kanager any improvements which the Co-Manager wimes to suggest. He shall have access to the teohnical reports, and to oopies of the finanoial reports provided by the Executing Agency to the Government. The Co-Manager will be the main channel by which the Government will be kept informed of the progress of the survey, with the Project Manager and the experts also having direct acoess to the Government agencies concerned.

22. A Project Committee will be formed, composed of the following pereons:

Chairman: - The Minister of Agriculture or Deputy Minister

- A representative of the Ministry of Planning

- The Director-General of the Geological Survey

- The Director-General of the Bureau of Soils and Irrigation 
- The Chief of Hydrology in the Ministry of Mines

- A representative of the Department of Topography and Aerial Photography, Ministry of Mines

- The Project Manager (ex officio)

Secretary: The Project Manager (ex offioio)

The Committee will meet as necessary, normally once every two months, being convened by the Chairman at the request of the Project Manager or Co-Manager. The primary work of the committee is to coordinate the work of the survey with that of other agencies, to which ond it will discuss the work in progress, arrange for the exchange of information relating to work already done by all agencies, and aoquaint the members with projects which are in preparation.

23. Under the general supervision of the Executing Agency and in consultation with the Co-Manager, the Project Manager will be responsible for the detailed planning, administration, and execution of the project, including the timing and budgeting of the various elements, the preparation of technical reports, and the organization and supervision of related training programs. The Project lianager will also be responsible for the coordination of the work of the various experts and groups of experts.

24. At times when one or.all teams are withdrawn to Kabul for the writing of reports and the plotting of their work, and when in coneequence the Afghan staff may not be fully employed, then such staff may at the request of the Government cooperating agency be directed by the Project Manager to any minor surveys or operations, usually lasting for one week or less, which are not covered by this Plan of Operation. Equipment, including vehicles, may be assigned to these minor operations provided that it is not needed for the other work of the survey.

25. Custody and Operation of Project Equipment

The project equipment will be allocated to the various experts and to counterparts by the Project Manager, and he will decide on its utilization. In cases where the equipment (other than vehicles which are covered by paragraph 26) is allocated to Government personnel, the Government undertakes to be responsible to the Erecuting Agency for its proper care and utilization. In respect of all equipment for which the Executing Agency has paid, the storekeeping facilities, and system of bookkeeping, shall be to the approval of the Project Manager.

26. Operation of Vehicles

(a) The drivers and mechanics for the vehicles of the Executing Agency will be appointed by the Government, and administered by the Co-Manager in respect of pay and working conditions. The Project Manager may require the replacement of any whom he considers unsuitable.

(b) The movements of vehicles in the field will be directed by the expert in charge of the party. 
(c) The issue of petrol and oil will be made by the Government. The expert in charge of the field party, or his counterpart, if authorized by the experts, will keep a log book. of petrol consumption, and he is empowered to certify a rate of petrol consumption in excess of normal, when such an increase has been caused by severe working conditions.

(d) The Government will perform and pay for the repairs and maintenance of vehicles, but the Executir.s Agency will control the supply of spare parts and will pay the cost of these from the Government cash contribution, when local purchase is possible. The Executing Agency will supply and pay for the equipment of a workshop in Kabul or elsewhere, adequate to perform normal running repairs and maintenance up to a limit of US $\$ 1,500$.

\section{System of Local fixpenditure}

The Government contribution in kind will be under the control of the Co-Nanager on behalf of the Government Cooperatine Agency. Annual budgets shall be prepared by the Co-Manager in consultation with the Project Manager in which the different items shall be in accordance with the approved plan: of expenditure set out in Appendix 2 . (Government contribution in kind). A copy of the budgets shall be given to the Project Manager for his information.

28. Solution of Minor Unforeseen Contingencies

In cases where the supply of labour, local material, and other items under the list of Government services and contribution, is not sufficient for the desired progress of work in the opinion of the Project Nanager or his authorized representative, then the Project Manager, or an expert acting for him, is empowered to remedy the situation as he sees necessary. He will do this by making payments from the Government contribution in cash as indicated in paragraph 9. The total expenditure made in this manner shall not exceed Afghanis 80,000 unless an increase is agreed upon by the two Agencies in an exchange of letters.

29. Air travel for all Afghan personnel is authorized on the Ariana air line in the interests of the work. The payment for tickets shall be made by the Government from ite contribution in kind.

\section{BUDGET}

30. In addition to the services and fecilities described in paragraphs 6 and 7 above, which shall be provided in kind to the project by the Government, and estimated to cost a total of Afghani 11,883,833, the equivalent of US $\$ 247,580$, as detailed in Appendix 2, and services and facilities described in paragraphs $6(c)(v)$, and (d) above, which shall be provided in cash to the project by the Government, and estimated to cost a total of Afghani 1,013,634, the equivalent of US\$21,117, as detailed in Appendix III, the estimated total Special Fund cash project budget amounting to the equivalent of US $\$ 789,550$, will consist of the following: 
(a) The gross cost of expert services, fellowships, equipwent and miscellaneous expenses, described in paragraphs 5 (a) to (d) above, to be met from the Speoial Fund allocation and amounting to an estimated total equivalent of US\$ 737,950, which includes an amount estimated at the equivalent of US $\$ 82.610$. representing cash payments in local currenoy to be made by the Government to the Speoial Fund for local operating oosts desoribed in paragraph 8 above.

(b) The overhead costs of the Executing Agency, US $\$ 51,600$ to be met from the Spooial Fund allocation.

\section{REPORTS}

31. The Government and Executing Agenoy will exchange financial and progress reports. The form, content and frequency of these reports will be agreed upon in an exchange of letters between the Government and the Executing Agency.

32. The Government and the Exeouting Agency jointly shall submit to the Special Fund at the ond of each calendar year a certified inventory of equipment purchased with the funds allocated by the Special Fund.

\section{CONCLUSIONS}

33. Upon completion of the project, a report will be submitted by the Government to the Speoial Fund, on the benefits derived from the project, and the aotivities planned by the Government to follow up the project, leading to the general development of Afghanistan.

34. At the successful conclusion of the project, the Government, the Executing Agency and the Special Fund will consult with a view to transferring the title of equipment from the Special Fund in whose name it is held by the Executing Agenay, to the Government or an agenoy nominated by the Government.

35. Agreed on bohalf of the parties, by the undersigned:

For the Government of Afghanistan

Mir M. Akbar Raza

President Water and Soil Survey Authority

Date: 19 June, 1963
For the United Nations Special Fund

Sixten Heppling

Resident Representative and Director of Special Fund Programmes

Date: 19 June, 1963

For the Food and Agriculture Organization

of the United Nations

S.K. Dey

Date: 19 June, 1963 
APPENDIX 1

UNITED NATIONS SPECIAL FUND - AFGHANISTAN: LAND AND WATER RESOURCES SURVEY

Revised Plan of Expenditure

United Nations Special Fund Allocation

Period Total

Man- Project

Mos. $\frac{\operatorname{Cos} t_{s}}{\$}$

\begin{tabular}{ccccc}
\hline 1960 & 1961 & 1962 & 1963 & 1964 \\
$\$$ & $\$$ & $\$$ & $\$$ & $\$$
\end{tabular}

1. Personal Services

$\begin{array}{lrlccccc}\begin{array}{l}\text { Water Development Engineer } \\ \text { (Project Manager) }\end{array} & 37 & 62,450 & 5,550 & 19,600 & 12,200 & 18,100 & 7,000 \\ \text { Senior Engineer } & 19 & 30,000 & - & 17,928 & 12,072 & - & - \\ \text { Hydrologist } & 39 & 57,200 & 4,500 & 14,378 & 17,900 & 15,400 & 5,022 \\ \text { Hydrometrist } & 41 & 50,900 & 3,000 & 12,200 & 16,600 & 14,100 & 5,000 \\ \text { Survey Engineers (2) } & 61 & 96,600 & 7,000 & 27,300 & 34,600 & 27,700 & - \\ \text { Engineering Geologist } & 29 & 49,600 & 6,000 & 17,500 & 18,300 & 7,800 & - \\ \text { Soil Surveyors (2) } & 56 & 79,600 & 2,000 & 25,200 & 36,200 & 16,200 & - \\ \text { Soil Chemists (2) } & 40 & 51,000 & - & 5,400 & 21,100 & 24,500 & - \\ \text { Land Use Planner } & 7 & 13,000 & - & - & - & 13,000 & - \\ \text { Hydraulic Engineer } & 12 & 22,700 & - & - & 1,500 & 21,200 & - \\ \text { Irrigation Survey Engineer } & 12 & 22,700 & - & - & 5,000 & 17,700 & - \\ \text { Administrative Officer } & 18 & 18,000 & - & - & 4,500 & 10,000 & 3,500 \\ \text { Short term consultants } & 4 & 7,000 & - & - & - & 7,000 & - \\ \end{array}$

$\begin{array}{llllll}375 & 560,750 \quad 28,050 & 139,506 & 179,972 & 192,700 & 20,522\end{array}$

2. Fellowships

Water Development Engineering Irrigation Engineer (2)24 )

Hydrology (2)

Chemistry (2)

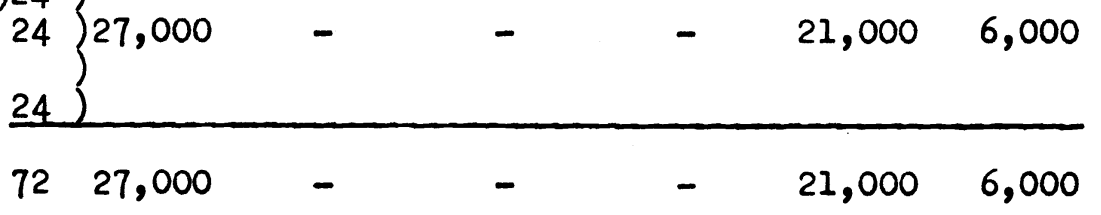

3. Equipment and Supplies

Topographic and hydrometric equipment

Soil laboratory and field

equipment

Camp equipment

Vehicles (including spares and small workshop)

Preparation of reports and maps

Drilling rigs

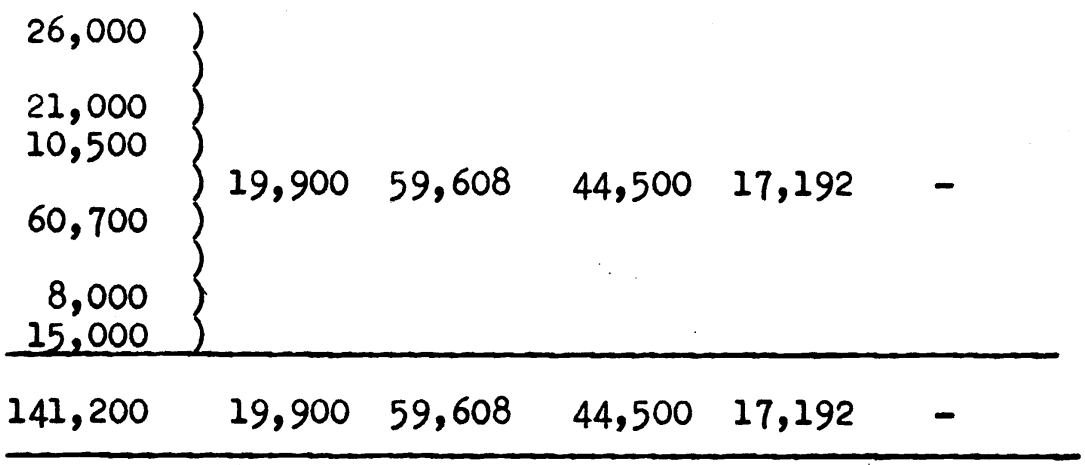




\section{APPEMIDIX 1 (Cont.)}

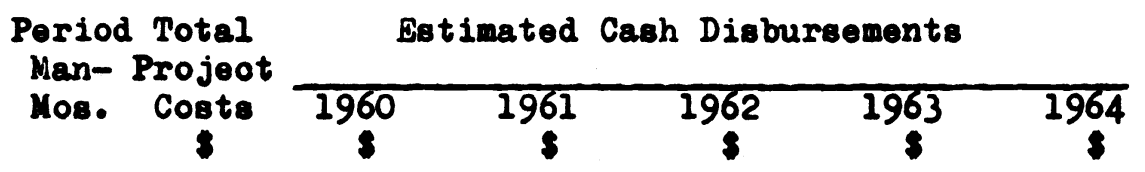

4. Miscellaneous

$\begin{array}{lllllll}\text { Post and cable charges } & 2,000 & 300 & 400 & 500 & 600 & 200\end{array}$

$\begin{array}{lllllll}\begin{array}{c}\text { Socretarial and olerical assis- } \\ \text { tance }\end{array} & 10,000 & 250 & 350 & 3,500 & 4,100 & 1,800\end{array}$

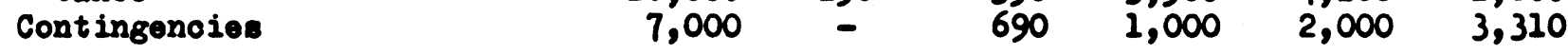

Total Gross Project Cost

$747,950 \quad 48,500 \quad 200,554 \quad 229,472 \quad 237,592 \quad 31,832$

5. Brocuting Azenoy Cost

$51,600 \quad 14,000 \quad 12,500 \quad 12,500 \quad 12,600 \quad-$

Speoial Fund Allocation $1 /$

$799,550 \quad 62,500 \quad 213,054 \quad 241,972 \quad 250,192 \quad 31,832$

1) The Special Fund Allocation includes the equivalent amount of US\$ 82,610 to be paid by the Government towards local operating costs of the project. This amount is payable by the Covernment in looal ourrenoy, in instalments as shown in Seotion III of the igned Plan of Operation, and has been calculated on the basis of a rate established in the manner presoribed in paragraph 8. 


\section{$\triangle P$ PPNDIX 2}

\section{UNITED NATIONS SPECIAL FUND - AFGHANISTAN: IUND AND HATER RESOURCES SURVEY}

Revised Plan of Expenditure

Government's Counterpart Contribution in Kind and Bstimated Cost

(Government's financial year starts on 21 Marob and ends on 20 March)

\begin{tabular}{|c|c|c|}
\hline $\begin{array}{l}\text { Period } \\
\text { Man }\end{array}$ & $\begin{array}{l}\text { Total } \\
\text { Cost }\end{array}$ & $\frac{\text { Estimated Cagh Disbursements - Afgs. }}{\text { for financial years }}$ \\
\hline $\begin{array}{l}\text { Mos. } \\
\text { Afgs. }\end{array}$ & & $1960 / 61$ \\
\hline
\end{tabular}

1. Professional Staff

1 Co-Manager (Hydraulic Engineer)

10 Civil Engineers or technicians and surveyors

6 Technicians

2 Agricultural engineers or agronomists

2. Clerical Drafting and Laboratory NonProfessional Staff and Labourers

4 Draftamen or photographers

2 Construction Foremen

18 Drivers

2 Vehicle Mechanics

1 Administrative Assistant

1 Stores Manager

1 Aocounts Clerk

1 Correspondence Clerk/Typist

Other admin. personnel and accounts personnel as needed. Labour: average of 30 men employed on survey + constmuction of gauges

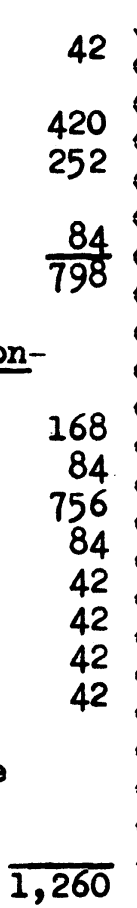

3. Allowances inc. oubsiatence travel within the country

4. Equipment and Supplies Aerial photographs and maps Fuel and lubricants for the vehicles supplied by the Executing Agency Construction of river gauging stations and meteorological stations Miscellaneous small supplies Two vehicles for local transport of counterpart staff, together with the fuel and lubricants for same
Salaries, Bonuses eto.

$4,615,507645,0001,070,5071,400,0001,500,000$

$1,540,540 \quad 170,000 \quad 370,540 \quad 500,000 \quad 500,000$

$6,156,047815,0001,441,0471,900,0002,000,000$

$4,795,770 \quad 700,1451,175,6251,460,0001,460,000$ 
Miscollanoous

APPEANDIX 2 (Cont.)

Period Total Estimated Cash Disbursements in Afghanis Man Cost for financial years

Mos.

Afg8. $1960 / 61 \quad 1961 / 62$ $1962 / 63$ $1963 / 64$

Supply of insurable small airoraft for reconnaissance flights Soil laboratory installation and facilitios Office accommodation for international and Afghan personnel including rent, office furniture, stationery, etc.

$$
932,016 \quad 180,000 \quad 235,100 \quad 256,916 \quad 260,000
$$

Transportation of material and storage expenses

Repair of vehicles and equipment excluding spare parts

Total estimated cost of counterpart

contribution in kind expressed in Afghanisill,883,833 1,695,145 2,851,772 3,616,916 3,7.20,000 
APPEIDIX 3

UNITED NATIONS SPECIAL FUND - AFOHANISTAN, IAND AND WAIER RESOURCES SURVEY

Revised Plan of Broenditure

Government's Counterpart Contribution in Cash

Estimsted Cach Dibbursements

Total expressed in Arghanis $1 9 6 0 \longdiv { 6 1 } \quad 1 9 6 1 / 6 2 \quad 1 9 6 2 / 6 3 \quad 1 9 6 3 / 6 4$

1. Repair of vehicles mupplied by UNSF, especially spare parts for the same

2. Hiring of occasional vehicles $1,013,634 \quad 647,000 \quad 3-3 \quad 183,317 \quad 183,317$ for transportation of personnel, labour and goods

3. Miscellaneous and Contingenoies

Total Government Cash

Contribution expressed in Afghanis $1,013,634 \quad 647,000 \quad 3-3 \quad 183,317 \quad 183,317$ 


\section{APPEANDIX 4}

UNITED NATIONS SPECIAL FUND - AFGHANISTAN: IAND AND WATER RESOURCES SURVEY

Revised Total Government Contribution

\begin{tabular}{|c|c|c|c|c|c|c|}
\hline & \multirow{2}{*}{\multicolumn{6}{|c|}{ Equivalent in US\$ }} \\
\hline & & & & & & \\
\hline & Total & $\overline{1960 / 61}$ & \multirow{2}{*}{$\frac{1961 / 62}{59,695}$} & \multirow{2}{*}{$\frac{1962 / 63}{71,367}$} & \multirow{2}{*}{$\frac{1963}{76,963}$} & \multirow{2}{*}{$\frac{1964}{19,375}$} \\
\hline $\begin{array}{c}\text { Counterpart contribution in kind } \\
\text { (Appendix 2) }\end{array}$ & 247,580 & 20,180 & & & & \\
\hline $\begin{array}{l}\text { Payment in cash for local } \\
\text { operating costs l/ } \\
\text { (Appendix I - seo footnote) }\end{array}$ & 82,610 & 18,577 & 36,871 & 21,691 & - & 5,471 \\
\hline $\begin{array}{l}\text { Counterpart Contribution in cash } \\
\text { (Appendix 3) }\end{array}$ & 21,117 & 6,740 & 6,739 & 3,819 & 3,819 & - \\
\hline TOTAL GOVERMMEAT CONTRIBUTION: & 351,307 & 45,497 & $10 \cdot 3,305$ & 96,877 & 80,782 & 24,846 \\
\hline
\end{tabular}

1 These amounts, payable in local currency, have been calculated on the basis of a rate established in the manner prescribed in paragraph 8. 


\section{APPEIIIX II}

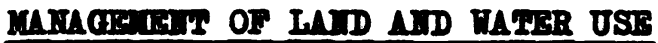

1. Conerel Considerations The oore of Afghanistan' economy is its arioulture and IIvestook Industry which omploys over $85 \%$ of all the able-bodied population and produoes $80 \%$ of the gross national product. The share of the produce of these activities in the country's exports exooeds $95 \%$.

Goographioally the country, distinguishod for its dry clinate, with hich temperatures and very limited rainfall, is characterized by an arid sone with a prevalling deficienoy of moisture. That is why productive agriculture is hardly possible here without irrigation, and in faot, over $50 \%$ of the total land under orops, about 4 nillion heotares, are on a orop-fallow rotation. Further development of agriculture is poseible only on the basis of irrigation developent. The extenaion of the irrigated area will involve the conetruction of dane and resorvolrs; in other words the country will have to sot up major hjdraulio etructures for the regulation of river flow, and will need qualified management of ite water renouroes.

With the growth of the national industries, there will be a constant increase in the level of mochanization in agriculture and irrigation. Hor stato-omed and othor farm (possibij of a new type) will use 1rrigation to moet the new requirements of planned organization of work and the teohnology of meohanized agrioultural production. For the same reacon, the reconstruotion and reorganization of all the -xisting irrigated areas will gradually be carried out. In this prooses, the available reserves of froe lands and water resources will be used to expand the irrigated areas. Lands already irrigated will be augmented through minor conetruotion, oarried out with looal facilities.

The Govornment of Afghanistan attaches great importance to the development of agrioulture and especially of irrigated faraing. An indioation of this is given bJ the allooations for agrioulture in the First Five-Ioar plan. Out of the total of Afs. 9216 million, agrioultural development was allooated Afs. 2798 million (over 30\%). Out of this appropriation, Afs. 2540 million was earnarked for irrigation alone, or $90 \%$ of the entire agrioultural budget. Every jear, the Covernment inoreaces oapital investments in the development of irrigation, and more and more hydraulio structures, large and mall, are being construoted for the purposes of reclamation.

2. Organisation Required Th1s complex of canals, hydraulio Installations and oupplomentary struotures, in a number of state-owned syotens, requiring oonetant proteotion, proper upkeop, and unfailing operation, will need a common contre to manage the water economy of the country. It is now very necessary to establiah suoh a body, which could, on the Government's behalf, deal with all the problem involved. The oontrol and use of water for irrigation is closely linked with the control and use of the lands on which it is to be applied. 
In order to coordinate and most effeotively the problems of managonent of land and water use under irrigation, it is suggested that one authority, best connected closely with the Kinistry of Agriculture, be responsible for the whole of this field, with wide terms of referenoe. This should be organised to inolude specialists in all branches necessary, including soils, irrigation agronomy, and, partioularly, hydraulic engineering, both at headquarters in Kabul and in the provinoial oentres where irrigated agriculture is practiced and will develop.

3. Terns of Referenoe It appears desirable that the Authority of Land and Water Use should be conoerned with the following range of problems:-

(1) Relationships between the Authority and other units of the Ministry of Agriculture and other seotions of Government;

(2) The Authority' organization and personnel;

(3) Terms of reference of the Authority's units;

(4) Structure and personnel of the Authority's local offices;

(5) Terms of reference of the Authority's local (provinoial) personnel;

(6) Survey and study of the land and water resouroes in individual irrigation systems;

(7) Preservation, improvement and development of the whole system of facilities for irrigation and reclamation, their maintenance, operation and repairs;

(8) Organization and exeoution of water intake, distribution and transport of water to the borders of consumers' plots;

(9) Removal of excess ground water from the irrigated areas;

(10) Investigation, preparation and execution of measures of reclamation against salinization, waterlogging and obstruction of the irrigation system;

(11) Proteotion against danage of irrigation installations and facilitios

(12) Organization and supervision of reconstruction of the existing irrigation canals and systems;

(13) Minor irrigation construction and construction of operation service building;

(14) Gradual introduotion of meohanization of work on irrigation drainage and reclamation, in the operation and reconstruction of the existing irrigation systems;

(15) Control over the condition of 1rrigation and drainage systems and Installations, as well as over rational use of the irrigation water by the consumer farms; 
(16) Organisation and establiahment of plantations to meet irrigation requirements for timber, and wind-break abelter belts;

(17) Organization of water measurement and means of communications on irrigation sytems

(18) Preparation of the main oadastral survey of irrigation and keeping of current irrigation oadastral murveys, as well as inventories of the systems of canals and hydraulic structures

(19) Recruitment, training and distribution of the engineering and teohnical personnel, and conditions of their appointment and dismissal;

(20) Organization of supply of the loogl offices with building materials, equipment, construction machinery, transport and communioations facilities, eto.

(21) Organization of all-round registration, stock-taking, acoounting and finanoing in the Authority including its local offices;

(22) Inspotion of maintenance, repairs and construotion activities in the looal offices

(23) Technical guidance in execution of minor irrigation construction and control over construction of water economy objeots, carried out by subcontractors;

(24) Aoceptance for operation of construction projects when carried out 3

(25) Registration, operation, replacement and construction of pumping stations for irrigation, drainage and water oupply;

(26) Organization and operation of a laboratory for analysic of samples of soils, sub-soils and water in the process of operation and reconstruction of irrigation systems;

(27) Research in the field of water economy;

(28) Organization of research, investigation and designing of reclamation work in the reconstruction of the existing irrigation systems and developing irrigated africulture, and also pastures;

(29) Preparation and submission for Government approval of anmal and long-term plans of activities and measures in the sphere of irrigated agricultures

(30) Preparation and submission to higher authorities of draft laws for water economy;

(31) Consideration and approval of designs, programmes and estimates for measures of irrigation and reclamation, as well as of other projects related to irrigation and drainage; and the aubmission of conclusions on projects put up for Government approval, 
(32) Elaboration and approval of instructions, mothods, tatuos and rules, for the teohnioal operation of canals and installations, for the aocoptanoe of completed projeots, for the reclamation service, oadastral surveje, inventorles, water use, etc.

(33) Convocation of congresses and conferences on the problems of water economy.

For rational management of the country' water economy, it is neceseary, firat of all, to study this economy - the existing, century-old, rich stook of large and small hydraulio installations and the lands now cultivated. With this purpose in riew, it is requialte now to engage in the operation, and, therefore, in the inventory, of Irrigation systems, as well as of irrigated lands.

This problem and reconmendations on it are discussed in the paragraphs below. Th1s 1s still more neceseary because In Afghanistan there has nover been taken any Inventory of aotually cultivated as rell as Irrigated lands, and no integrated or separate sohemes of land and water resouroes use have ever been prepared.

4. Operation of Irrigation Sratem Smoothly organized operation of Irrigation systems and proper development of Irrigated lands are of great national importanoe. Only thus can irrigation be fully effoctive, with ample jields of agricultural crope, productive utilization of irrigated areas and irrigation water, high effoctiveness of finanoial and material investment.

The absenoe of a government authority for water eoonomy, and the present sjotem of land ownerahip on Irrigated lands, under which a considerable part of the lands and irrigation canal are being used without proper oentralized and qualified tate control, in no way contribute to effective use of rater in agriculture. The results to be ainod at inolude high and steady jields from irrigated landa, high officionor of the irrigation sjitems, progreasive inorease in fertility of Irrigated solle, prevention of high ground water lovels and woil salinization, higher ooeffloient of use for cropped arean, normal water coneumption por unit irrigatod areas, and good maintonance of oanals and installations.

All these objectives depend to some extent on correct operation of individual oanals, as well as entire Irrigation syotoms. The main operational tasks must be:

(1) Uninterrupted intake of water from Irrigation souroes;

(2) Timely convejance and distribution of irrigation rater among individual or collective water consumers;

(3) Convejance of water to the plote acoording to the requirements of the various orope;

(4) Drainage of exoess water, to proteot irrigated lands from waterlogging and salinization.

Iike anj machine, an irrigation aystom nust work exactly, on correot tining. For this it must be in good order. 
5. Rules of Operation The conditions of operation can be defined in rules, which should cover the following:

(a) The Rules for technioal operation of irrigated systems mast define the system of water intake, conveyance and distribution, priorities of reolamation services for the irrigated areas, keeping canals and installations in good working condition, order of carrying out inventories of the irrigation systems, the schedule of duties for the personnel of the irrigation systems, as well as the rendering by them of qualified technical assistance to the oonsumers in the improvement of the irrigation of their plots;

(b) Rules must establish the dimensions, standards and quality specifications for the operation of the canals and installations, for the methods of using water by the farms for both irrigation and reclamation, and the procedure of conveying the water in the canals and distributing it to the consumers

(c) It is assumed that the Rules will be applioable to all the agenoies engaged in agriculture, and to all persons concerned with the irrigation systems;

(d) It is also anticipated that these Rules will be common for all the irrigation systems in the country; supplements to them oan cover the peculiarities of particular irrigation systems or individual major canalss

(e) The Rules should also deal with the procedure of acceptance for operation of newly built irrigation systems or individual canals and structures, with a view to the immediate inventory, in appropriate terms, of a system, a canal or a structure as soon as built.

Such contents of the Rules for technical operation of irrigation systems, provided they are strictly adhered to, will ensure correct and complete use of irrigation waters, and unfailing conveyance of water through canals and installations, and will protect irrigated areas from damage, waterlogging, salinization and contamination with malaria.

6. Inventories of Irrigation Installations The essential pre-requisite for the successful operation of irrigation systems will be knowledge of the current technical condition of a whole system, as well as of its elements: oanals, structures and facilities.

The necessary details can be obtained only through correct registration, consisting of a description of the constituents of a system - its canals and installations, supplemented with principal technical and economical characteristics shoving the condition of the system, its cost, and the estimated duration of its normal service. Such a registration, or inventory, of the irrigation systems, acoording to practices established in many countries, is taken annually for comparatively small systems, and periodically (every 5 to 10 years) for larger ones. When the inventory of a system is available and its registration is made, it bocomps possible to schedule correctly its running, renewals and maintenance, to outline research and building work for its reconstruction, extension and technioal improvement, and to determine other measures to be taken. When established, the inventories of the systems should regularly be brought up-to-date. 
To ensure comparable and summarized reglstration data, the inventory of all types of Irrigation ajetems ahould be carried out in striot confornity with general tabular forms and instruotions, These documents ahould bo compiled by the Authority of Iand and Water Use and ooordinated with the Ministry of Aarioulture as well as with the statistiosl department of the Kinistry of Planning.

Teahnical inventory of the irrigation syetems, if carried out all orer the country, will take a long time, and will require an expenditure of seolal funde, and the training, spoifloally for this rork, of an extra mubor of apocialiate. Thorefore, there should be established prioritien for the implenontation of this work within zones, as well as in the country as a whole.

Along with the inventories of the irrigation systems, regietration and ovaluation of all the Irrigated areas will be carried out with their complete reclanation characterist10s, taking aooount of their relation to the canais feeding these areas with irrigation water. Suah registration and ovaluation should be otartod at onoe In the basins of the Barl Bud, Kabul and Farah Aud, so that the planned irrigation development oonnooted with the reorganization of the existing irrigation ayeteme can be solved in an appropriate way in the process of proparation of the designe. 


\section{APPEADIX III}

METHODS USED IN INVESTIOATIONS \& PLANNIDO

1. Deta and Investigations In working out schemes to use the water resources of Afghan rivers for future complete development of all branches of the national economy, the first task is the collection and arrangement of the necessary initial data. These data include:

i.) Naps on soales 1:500,000 - 1,000,000 to study the general questions, and on soales $1: 50,000-1: 100,000$ shoving the present conditions of use of water resources to solve speoific problems and prepare proposals.

ii) Climatio oharacteristios of the distriots examined.

iii) General data about geology and soils in these distriots.

iv) Data of available water resources, including mean monthsly discharges, maximum and minimum discharges and preliminary data about sediment discharge.

v) Data about present irrigation standards and conclusions on the prospective use of irrigated areas and irrigation standards.

After the colleotion and arrangement of the data mentioned above, preliminary alternative sohemes for the use of the water resources of various streams are worked out. When the initial data are incomplete, then the minimum volume of additional investigations is soheduled, and the possible altermatives are based on general conclusions.

In the process of preliminary work on alternatives, it is necessary to oarry out on the basis of the data available, tentative entimations of the irrigation capacity of a river and of its potential porer resources.

When the preparation of preliminary alternatives is finished, the reconnaissance hydro-teohnical investigations are carried out. The tak of these investigations is to cheok right on the spot the altermatives already prepared, to define the character and volume of additional investigations, and also to choose the most advantageous variant of the scheme. Therefore the group oarrying out the reconnaissance investigations consists of: Hydraulio technioians, Topographers, Geologists and Soil Soientists; the presence of an Economist is desirable.

To reduce the volume of further investigations, those taking part in the reconnaissance investigations give their conolusions on questionss e.g. the Soil Scientists on soil conditions, the Topographers on alternative sites for dams and reservoirs and so on.

The Dam Designer, analysing the local conditions, gives his conclusions about constructive solutions for the projeots. Wen all the questions arising in the process of investigations are speoified, the final volume of investigations and the terms of their fulfilment is defined.

At the same time as some parts of the investigations are being carried out, alternatives are prepared. 
2. Sohemes of Irrigation Dovelopment The irrigation capaoity of a river in heotares is measured by the proportion of its anmul run-off to the arerage annual water requirements per heotare. The irrigation potential can be stated at three. standards:

i) Irrigation potential of the natural flows of a river.

ii) Irrigation potential with seasonal control of the run-off.

iii) Irrigation potential with over-year storage.

The irrigation potential of a river at natural flow is determined by the critioal period, when the flows available are only just enough to meet the requirements of irrigation at the time. Under the Afghan conditions, only planting of wheat and barley provides the maximum potential of the rivers, since their maximum water requirements occur in epring, i.e. during the flood period on the rivers.

Seasonal control of the run-off will make it possible to vary the oropping plan. With the seasonal run-off control, the irrigation potential of a river is measured by the proportion of its anmal run-off in a year of aseumed probability to the average irrigation requirements gross per heotare. The estimated probability of irrigated farming, according to the experience in the Asian Republic of USSR, should be taken as $75 \%$.

The average irrigation requirements are defined from the graph of water requirements in 1/8eo/per hectare on various alternative oropping plans. The average coefficient of efficiency of the system oan be taken as 0.60 in the basins studied.

The volume of seasonal control to be provided will be a minimum when the regime of irrigation requirements and the regime of discharge of the source of irrigation differ least. The irrigation potential of a river with over-year storage is measured by the proportion of its average anmual run-off to the average anmual imrigation requirements, gross per hectare.

It is necessary to point out that in determining the irrigation potential of a river with seasonal and over-year storage, the run-off used in the estimations has to be reduced by the amount of the losses in the reservoirs. For the better coordination of irrigation development with the ultimate prospective proposals in the scheme first of all the complete use of all the water resources of a source of irrigation, with over-year storage in all the necessary reservoirs, is worked out. Then of the complete works, according to the economical indices, the items of highest priority are chosen, and on these additional estimations are made. When the irrigation potential of the river is determined, then on the basis of soil and hydrogeological maps the areas which can be irrigated are defined. On these areas, in accordance with soil-reclamation conditions, the project of the necessary technical measures is outlined. This includes: headworks on the river for water intake, main and distributary canals, field irrigation system, drainage system, including collector drains if necessary. For the determination of quantities of work involved in the construction of an irrigation system, the intake headworks, the main canals and a typical part of the distributaries are designed, and the quantities of work which they involve are determined. For the determination of quantities of work on field irrigation systems a typical plot is chosen which may be $5 \%$ or $10 \%$ of the whole area. On this plot an irrigation system, and if necessary a drainage system, is designed with profiles and estimations of quantities of work* On the basis of these quantities, the specific indices of work per unit of area are obtained and then using the specific indices the quantities of work connected with the construction of a field irrigation system on the whole outlined area are determined.

* including land levelling, if necessary 
The typical oross-seotions of irrigation ohannols used were in acoordance with the standards of design for irrigation aystems worked out in the USSR. The hydraulic estimations have been done by the help of a slide-rule made by Bngineer V.F. Pojarkor in 1956.

3. Nater Balance Estimations and Estimations of Bun-off Control in Reservoirs In acoordanoe with the soheme of irrigation d6velopment worked out, and the additional areas to be developed, the water requirements of the irrigation system out of a river are defined at this or that point on its course, as appropriate, and either in mean monthly discharges or in volumes.

These requirements defined are compared with the available water resources of the river, whioh have been ascertained in the hydrologioal part of the investigations. The water requirements and water resouroes are balanced month by month and excesses and shortages are determined. Bramples of this estimation are the water balanoe estimations on the Hari Rud, Farah Rud and Kabul rivers, given in Volume $\nabla$ of this Report. It is necessary to point out that in water balance estimations in conditions of uncontrolled run-off, the irrigation requirements in any assumed year must be less than or equal to the available water resources of the river. In some months these may be deficits, but these defioits must not be more than 10-15\% of the full irrigation requirements in the given month; in dry months the irrigation requirements will have to be reduced by the amount of these defioits.

With seasonal or over-year storage, the excesses defined in the water balance estimations are stored in reservoirs, and the shortages are compensated by releases from reservoirs.

With seasonal control, the run-off of the designed dry year ( $75 \%$ probability) has to be stored in reservoirs; in years of higher flow ( $50 \%$ or $20 \%$ probability) releases from reservoirs in excess of irrigation requirements are inevitable.

Over-year storage is usually oarried out not only in one reservoir but in several. In this, part of the reservoirs are for seasonal control, and the remainder are for over-year storage.

In the estimations of over-year storage, the total capacity required for control is divided into two components, for seasonal and for over-year use.

The amount of the seasonal component is defined on the basis of a low year of $75 \%$ probability, and is equal to the neoessary controlled rolume in such a year.

The value of the over-year oomponent is determined by the following formala, proposed by the Soviet scientists M.F. Menkel and S.N. Kritskij:-

$V_{\text {multiannual }}=\beta \quad V_{0}$ wheres

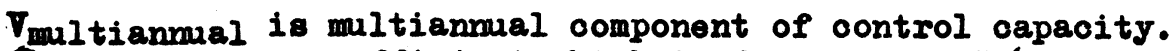

$\beta^{-00 e f f i o i e n t}$ wioh is funotion of " $\alpha$ " which is in its turn

$\begin{array}{ll}\text { C. } & \text { the ratio of the used run-off to the average } \\ \text { P } & \text { - the percent of variation of anmal run-off }\end{array}$

$\begin{array}{ll}\mathbf{P}_{0} & \text { a the percentage of probability (see Glo } \\ \nabla_{0} & =\text { average anmal run-off of the river. }\end{array}$ 
For the determination of value of the coeffioient n/ n, the authors of this formula on the basis of mathematioal statiatios and theory of probability in water oontrol estimations have established a graph of the funotional relationship $\beta=\Phi\left(\alpha, C_{T}\right.$ and $\left.P\right)$. The oum of the defined values of the seasonal and over-year components gires the complete effeotive control oapacity -

$$
\nabla_{\text {eff.storage }}=\nabla_{\text {Beasonal }}+\nabla_{\text {over-year storage }}
$$

For the determination of the complete oapacity of reservoirs, it is necessary to add to the effective storage the dead storege, the amount of whioh is determined in .acoordance with the conditions of silting over the estimated number of years, usually taken as 100. Thus multiplying 100 by the average anmual volume of silting, gives the dead storage required in a reservoir.

As mentioned above, the amounts of the complete capacity of various designed reservoirs differ. They are limited by the topographical, geological and economical factors in each case. For comparison of reservoirs, coefficient of controlled stream at the site of each reservoir is computed. This coefficient is the ratio of the effective volume of the reservoir to the average anmal run-off of a river at the reservoir site:-

$$
K=\frac{V_{\text {effective }}}{\nabla_{0}}
$$

If coefficient $K$ does not exceed $0.4-0.5$ for any given reservoir, then it is possible to introduce it for seasonal control; at higher values of its coefficient, over-year storage is possible. An example of this is given by the reservoirs in the Hari Rud basin.

The Assarassum and Salma reservoirs, with coefficients of 0.41 and 0.40 , provide the seaconel run-off control in the basin while in the reservoirs at Tangi-Shah and Tangi-Azso, where $K$ is 1.72 and 0.96 , it is possible to provide over-year storage.

4. Design of Reservoirs and Dams In accordance with the results of investigations the reservoirs are designed. The type of the dam chosen is influenced by geologioal and economic factors. It is necessary to point out that in the conditions of the mountainous part of Afghanistan, where the run-off control vill be more effective, the geological conditions are extremely complioated. While most of the districts have comparatively weak seismioity, as the realt of former tectonio activity, displacements of the mountain rooks have occurred, which have resulted in faults, in many cases along the river channels. Besides, there are no fine materials for the construction of impermeable cores or water-tight facings in the rock-fill dams, a type which is the most economical and resistant to earthquakes.

For these reasons, the predominant types of dam here are the concrete-gravity dam, and, more rarely, the rook-fill dam with conorete faoing.

Beoquse of the oomplioated geologioal conditions, light arch dams will not be widely used here, though some sites are suitable for them as far as topographical conditions are concerned.

As can be seen from the hydrological Report (Volume III), the figures most subject to error are those of the maximum flood disoharges, the value of which influenoe the type and dimensions of spillway installations in the dams. 
Taking into consideration the merely preliminary character of the data of estimated maximum water discharges, there are no grounds for the reduction of the assumed flood discharges to be passed. Therefore the spillway installations were designed for definite maximum flood discharges as calculated in hydrological estimations, and did not take into account the amounts of water which could be passed through the penstocks of power houses, irrigation outlets and other installations of the dam.

The peculiarity of the projects at reservoirs, especially of those without power stations, is the necessity to establish special outlets from reservoirs for the irrigation water.

The elements of such an outlet and its constructive design are to be determined in accordance with the type of dam. In a concrete dam the outlet is formed as two pipes built in the body of the dam, and controlled by gates. The dimensions of the pipes must be such that they will provide for the passage of the required water discharge at the minimum water level in the reservoir.

Taking into account the approximate nature of the estimations, at this stage of planning the probable need of additional discharge capacity can be foreseen; this should be 50\%. In this case, even if one pipe is entirely closed, all or nearly all the discharges required can be passed, except in the one month of maximum demand, when only $75 \%$ of that demand can be passed.

The estimations of all elements of the project have been done in accordance with the standards accepted in the USSR for the designing of hydrotechnic installations.

5. Costs of Schemes and their Economic Implications The absence of experience of large-scale construction in Afghanistan and actual rates of construction work complicate the task of defining the cost of items and installations proposed by the schemes.

Therefore costs were determined approximately on the basis of general conclusions. For this reason, one of the main tasks of future investigations will be the study of construction experience in Afghanistan, and the collection of data about the costs of various kinds of work. It will also be necessary to collect data about the average prices of the main construction materials, and to coordinate them with the leading Ministries of the Royal Government in Afghanistan. Similar data will be required for the definition of transport costs.

The preparation of definite appraisals of the economic effectiveness of measures proposed in a scheme is complicated, as is the definition of the value of agriculture production to be expected after a scheme has been carried out. A method will have to be worked out to define the agricultural production, and to allow for the rate of interest on investments.

The solution of these problems will place in the hands of designers in the future stage reliable data for the determination of economical indices for the various parts of the schemes and will enable them to select the most profitable solutions from the measures recommended. 
IIST OF FIMAL BEPORTS OF PROJBCTS BI FAO UNDRR EPEA, RELEVANT TO THE SPECIAL FUND SURVEI PROJECT

Beport No.

84

147

195

253

204
Author

W. Sommerauer

T.A. Pasto

Lars S. Agerbers

W. Sommerauer

G.S. Cotterell

W.Grove, C.O. Allen, and E. Plerson

G.S. Cotterell

Ian S. MoRae

H.I. Khan

H.E.K. Nouman

B. Clarke

E.F. Abcarius

W.F. van Beers

H.H. Buohmann

A.T. Potersen

T.W. Peters

E.K. Economidis

a. Remaudiòre

K. Koe and T.K. Haia

B.P. Savema
Title

Dete

Small Agrioul tural Implements

1952

Agriculture (General Report)

1953

Seed Improvement

Small Agrioultural Implements and Farm Tools

1953

Plant Protection and Locust Control

1954

Control of Animal Diseases *

Plant Protection and Locust Control

Livestook Development and Animal

Disease Control

Possibilities of Agricultural

Co-operative Organization in

Afghanistan

Plant Protection and Iocust Control

1957

Forestry Development

Improvement of Fruit Production

So1ls and Soll Survey Needs in relation to Boonomio Development

Farm Implements and Snall Powered Nachines

Improvement of Irrigation

So1l Surver

Agricultural Extension

Sunn Pest

Serioul ture

Land and Water Use Development 